\title{
THE GEOLOGY AND GEOCHEMISTRY OF THE EAST AFRICAN OROGEN IN NORTHEASTERN MOZAMBIQUE
}

\author{
R. BOYD AND $\varnothing$. NORDGULEN
}

Geological Survey of Norway, N-7491 Trondheim, Norway

email: Rognvald.Boyd@ngu.no; Oystein.Nordgulen@ngu.no

\section{R.J. THOMAS}

British Geological Survey, Keyworth, United Kingdom

email: bthomas@bgs.ac.uk

\section{B. BINGEN, T. BJERKGÅRD, T. GRENNE, I. HENDERSON,} V.A. MELEZHIK, M. OFTEN, J.S. SANDSTAD, A. SOlLI, E. TVETEN AND G. VIOLA Geological Survey of Norway, N-7491 Trondheim, Norway email: Bernard.Bingen@ngu.no; Terje.Bjerkgard@ngu.no; Tor.Grenne@ngu.no; Iain.Henderson@ngu.no; Victor.Melezhik@ngu.no; Morten.Often@ngu.no; Jan.Sandstad@ngu.no; Arne.Solli@ngu.no; Einar.Tveten@ngu.no; Giulio.Viola@ngu.no

R.M. KEY AND R.A. SMITH

British Geological Survey, Edinburgh, United Kingdom email: rmk@bgs.ac.uk; ras@bgs.ac.uk

\section{E. GONZALEZ}

Institute of Geology \& Mineralogy of Spain, Madrid, Spain email: e.gonzalez@igme.es

\section{L.J. HOLLICK}

British Geological Survey, Exeter, United Kingdom

email: lhollick@bgs.ac.uk

\section{J. JACOBS}

Department of Earth Sciences, University of Bergen, Norway.

email: joachim.jacobs@geo.uib.no

\section{JAMAL}

University Eduardo Mondlane, Maputo, Mozambique email: daud.jamal@uem.mz

\section{G. MOTUZA}

Department of Geology \& Mineralogy, University of Vilnius, Lithuania email: Gediminas.Motuza@gf.vu.lt

W. BAUER

Aziana Exploration, Antananarivo, Madagascar

email: bauer.geol@web.de

E. DAUDI, P. FEITIO, V. MANHICA, A. MONIZ AND D. ROSSE National Directorate of Geology, Maputo, Mozambique email: edaudi@tvcabo.co.mz

\section{Please provide email address for all authors}

(c) 2010 March Geological Society of South Africa 


\begin{abstract}
The geology of northeastern Mozambique has been remapped at 1:250 000 scale. Proterozoic rocks, which make up the bulk of the area, form a number of gneiss complexes defined on the basis of their lithologies, metamorphic grade, structures, tectonic relationships and ages. The gneiss complexes, which contain both ortho- and paragneisses, range from Palaeo- to Neoproterozoic in age, and were juxtaposed along tectonic contacts during the late Neoproterozoic to Cambrian Pan-African Orogeny. In this paper we describe the geological evolution of the terranes north of the Lurio Belt, a major tectonic boundary which separates the complexes described in this paper from the Nampula Complex to the south. The Marrupa, Nairoto and Meluco Complexes are dominated by orthogneisses of felsic to intermediate compositions. Granulitic rocks, including charnockites, are present in the Unango, M'Sawize, Xixano and Ocua Complexes (the last forms the centre of the Lurio Belt). The Neoproterozoic Geci and Txitonga Groups are dominated by metasupracrustal rocks at low metamorphic grades and have been tectonically juxtaposed with the Unango Complex. Geochemical data integrate and support a model of terrain assembly in northeast Mozambique, which is largely published and mainly derived from our new geochronological, lithostratigraphic and structural work. This model shows the contrast between the mainly felsic lower tectonostratigraphic levels (Unango, Marrupa, Nairoto and Meluco Complexes) and the significantly more juvenile overlying complexes (Xixano, Muaquia, M'Sawize, Lalamo and Montepuez Complexes), which were all assembled during the Cambrian Pan-African orogeny. The juxtaposed terranes were stitched by several suites of Cambrian late- to post-tectonic granitoids.
\end{abstract}

\section{Introduction}

Northeast Mozambique offers an important transect across the southern part of the East African Orogen (EAO: Figure 1), from its Palaeoproterozoic basement along the shore of Lake Niassa to the Indian Ocean coastal plain. It lies at a critical junction between the north-south trending "Mozambique Belt" (e.g. Holmes, 1951) and the east-west trending Zambezi-Irumide Belts. The broad geology of this region is known from studies carried out by the Bureau de Recherches Géologiques et Minières (BRGM) in the early 1970s and 1980s (e.g. Jourde and Wolff, 1974). Teams from the former Soviet Union and several Eastern European countries studied selected areas in the 1980s, and a photogeological survey focussing on mineral resources was carried out by Huntings Geology and Geophysics Ltd (1984). More detailed work in certain parts of the country was carried out by other teams (e.g. Aquater, 1983 a-f; Costa et al., 1983; 1992). The BRGM work included geophysical and geochemical studies of priority mineralised areas and geological mapping which was compiled at 1.250000 scale. This key work, synthesized by Pinna et al. (1993), which covered the area north of $17^{\circ} \mathrm{S}$ and east of $34^{\circ} \mathrm{E}$, relied on $\mathrm{Rb}-\mathrm{Sr}$ whole-rock geochronological data and formed the basis for a lithostratigraphic scheme upon which the 1:1 $000 \quad 000$ scale geological map of Mozambique (Pinna and Marteau, 1987) and later syntheses were based (Saachi et al., 1984; Lächelt 1993; Lächelt and Daudi, 1999; Marques et al. 2000, Kröner, 2001; Marques, 2002, Lächelt 2004; Thomas et al., 2006; Grantham et al., 2008). Jamal (2005) reported $\mathrm{U}-\mathrm{Pb}$ zircon data on a number of units and this study is an important recent contribution to understanding the geology of the eastern part of the area.

A new reconnaissance mapping project aimed at producing 1: 250000 scale geological maps of the whole of Mozambique was undertaken in the period 2002 to 2007, in cooperation with the National Directorate of Geology of Mozambique (DNG). The ca. $260000 \mathrm{~km}^{2}$ area of northeast Mozambique delineated in Figure 1 was mapped by the "Norconsult Consortium", a consortium of the Geological Survey of Norway and the British Geological Survey, headed by the Norwegian company Norconsult and aided by the Mozambican engineering company, Eteng Lda.. In addition to geological mapping, the project included structural, geochemical, petrological and geochronological studies, and an inventory of mineral resources. The results were reported in Norconsult Consortium (2007 a; b).

In this paper we summarise the results of this mapping project, focussing on the field, petrographic and whole-rock geochemical data and on contrasts between the resulting findings and earlier interpretations (Pinna et al., 1993). The paper describes the area north of the Lurio Belt - the area immediately to the south, the Nampula Complex, was mapped partly by the Norconsult Consortium and partly by the Council for Geoscience (CGS) of South Africa. Details of the Nampula Complex will be published elsewhere. Here we describe the main lithostratigraphic units recognised and propose a revised tectonostratigraphic model of the crustal architecture of this important segment of the East African Orogen. Geochemical data are presented with the aim of providing an overview of the geochemistry of the crust in northeastern Mozambique. The samples were collected in order to characterize the major and trace element composition of exposed rock units, and not to support process-oriented geochemical research. Structural, geochronological and other thematic data are published elsewhere (Engvik et al., 2007; Melezhik et al., 2006; 2008; Viola et al., 2008; Bingen et al., 2009; Bjerkgård et al., 2009). These articles represent an integral part of our study and were fundamental in proposing the model discussed: the reader is referred to those publications for more details. The objective of this paper is thus to summarise the tectonostratigraphic scheme for northeastern Mozambique adopted in the new maps and to discuss this in relation to previous models mainly that of Pinna et al. (1993). 
M OFTEN, J.S. SANDSTAD, A SOLLI, E TVETEN, G. VIOLA, R.M. KEY, R A SMITH, E. GONZALEZ, L, HOLLICK, J. Jacobs, D. Jamal, G. motuza, W. Bauer, E. DAudi, P. Feitio, V. manhica, A. Moniz And D. Rosse

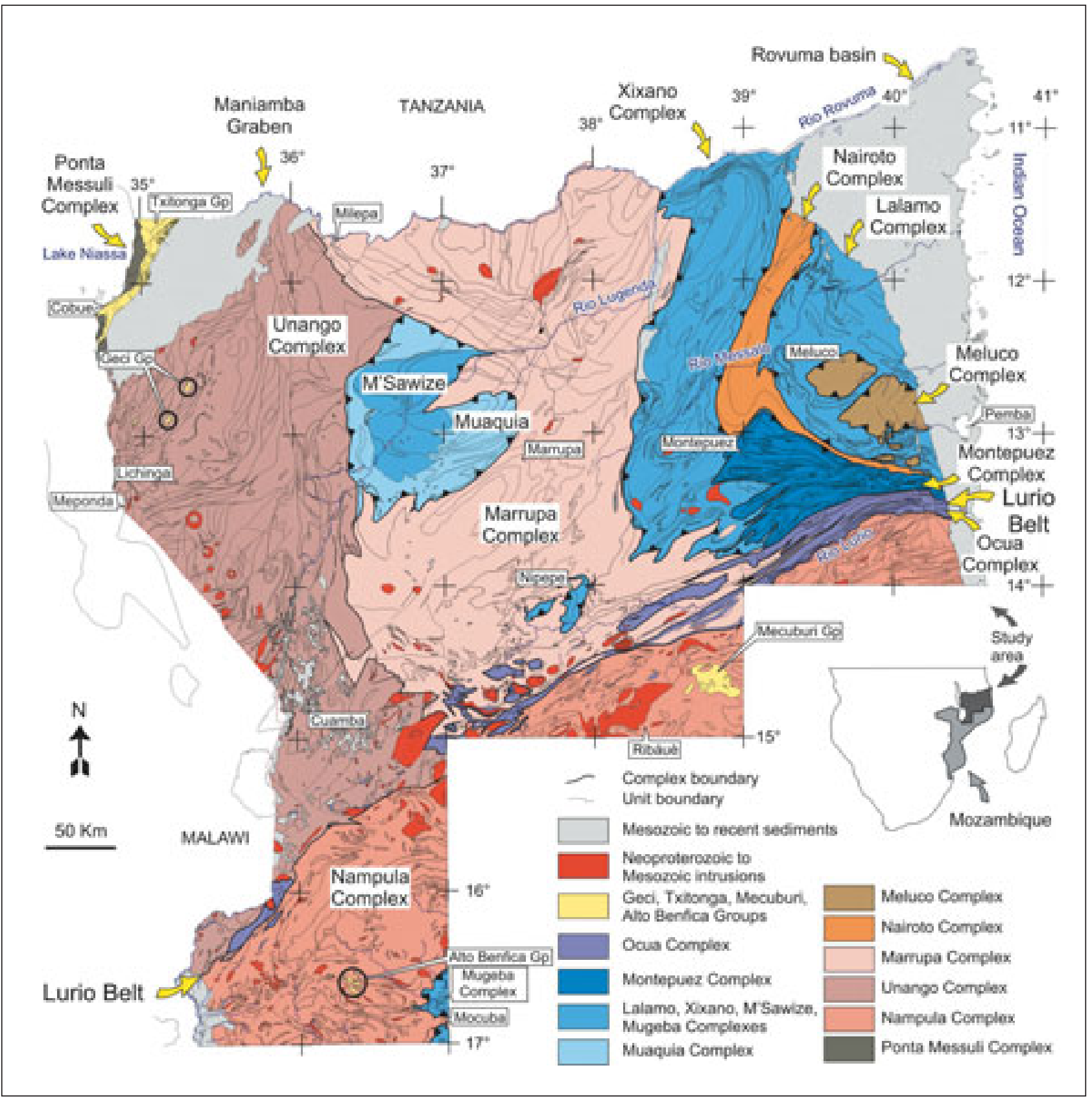

Figure 1. Sketch map of the main geological units in northeast Mozambique based on compilations at 1:250 o00 scale. This paper describes the geology of the area north of the Lurio Belt (north of the Nampula Complex). Thick lines mark the boundaries between Complexes and thin lines the boundaries of individual rock units from the 1:250 000 map. The main thrust contact separating the mainly felsic lower tectonostratigraphic complexes (rose colours) from the overlying more juvenile complexes probably formed outboard of the Congo-Tanzania Craton foreland (blue colours) is decorated by saw-teeth.

\section{Geological setting of northeastern Mozambique}

The crystalline basement of northeastern Mozambique is overlain by Permo-Jurassic Karoo sedimentary rocks, mainly along the northeasterly to southwesterly trending Maniamba graben in the northwest of the study area, and by Jurassic-Neogene sediments of the Rovuma Basin in the coastal area (Figure 1). The crust exposed between these basins is mainly made up of Precambrian (Palaeo- to Neoproterozoic) to Cambrian high-grade gneisses and Neoproterozoic to Cambrian intrusive plutonic rocks. It includes a prominent, eastnortheasterly to west-southwesterly trending PanAfrican shear zone, known as the Lurio Belt (Figure 1). The 25 to $30 \mathrm{~km}$ wide, north-northwesterly dipping Lurio Belt extends over $600 \mathrm{~km}$ across the study area. It is expressed by a strong zone of flattening in the east, which grades laterally into a complex zone of anastomosing shear zones and folds towards the southwest (Viola et al., 2008). 


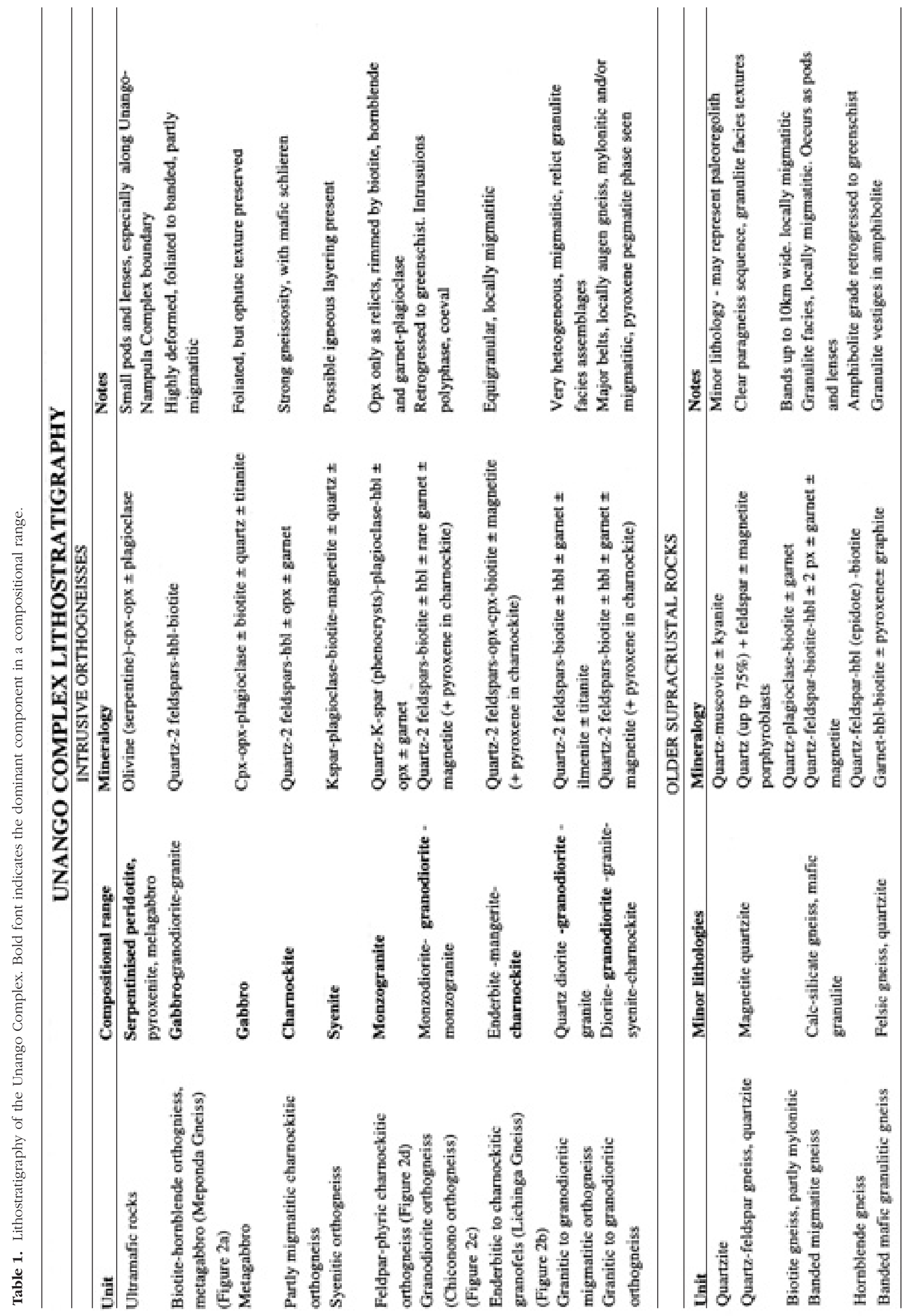


J. Jacobs, D. JAmal, G. MOtuza, W. BAuer, E. DAudi, p. Feitio, V. manhicA, A. Moniz And D. ROSSE

\section{Nomenclature and analytical methods}

The new mapping, supported by geophysical data and $\mathrm{U}-\mathrm{Pb}$ zircon geochronology, required the development of a new tectonostratigraphic scheme in northeastern Mozambique, because the available nomenclature proposed by Pinna et al. (1993) suffers from two main fundamental shortcomings:

1. It makes extensive use of the lithostratigraphic terms "Group" and "Supergroup" for rocks that are not only strongly deformed and subject to high-grade metamorphism, but also of mixed, igneous and metasedimentary parentage;

2. The lithotectonic units as defined in Pinna et al. (1993), cross the Lurio Belt, which is now regarded as a first-order tectonic zone (terrane boundary) (Viola et al., 2008). In addition, the distribution, correlation and geographic extent of many of units recognized by Pinna et al. (1993) have been substantially revised during the current survey.

In this work, the Proterozoic rocks are divided, instead of groups and supergroups, into a number of gneiss "complexes" on the basis of lithostratigraphy, metamorphic grade, structure, tectonic relationships and age (Figure 1). The terminology employed is based on the definitions contained in The Mozambique Code of Stratigraphic Terminology and Nomenclature (Direcção Nacional de Geologia, 2001). The complex metamorphic and structural development of most of the regional-scale geological units in the area described, necessitates the use of the lithodemic terms "suite" and "complex" rather than standard lithostratigraphic terms such as "group" as no "relationship to the original stratification" is preserved. The term "Complex" is defined as follows: "...characterized by structural complexity and/or lithological diversity." All the regional-scale high-grade basement units lying tectonostratigraphically below the exposed Neoproterozoic metasedimentary sequences (Txitonga and Geci Groups) conform to this definition. The complexes are the equivalent of "terranes" in a tectonostratigraphic sense. In the following sections, the complexes are described in order of observed ascending tectonostratigraphic level and age.

Grenvillian-aged orogenic events, straddling the boundary between the Mesoproterozoic and Neoproterozoic, are referred to as "Kibaran", "Irumide/ Irumidian" and "Namaquan" in various parts of Africa. In Mozambique, the terms "Mozambican" (Pinna et al., 1993) or "Lurian" Orogeny (Jourde and Wolff, 1974) have been used to cover this orogenic cycle. These two terms are abandoned here as the metamorphism in the "Mozambique Belt" and "Lurio Belt" can be demonstrated to be mainly late-Neoproterozoic to Cambrian (e.g Bingen et al., 2009). The Irumide/Irumidian orogeny, well described in the Irumide Belt of Zambia along the margin of the CongoTanzania Craton (DeWaele et al., 2006), is the most appropriate name to refer to Grenvillian-aged orogenic events in northeastern Mozambique. Subsequent to
Mesoproterozoic events, the "Pan-African" orogeny is a broad term to describe the protracted Neoproterozoic to Cambrian orogeny in Africa. High-grade metamorphism attributed to this orogeny in eastern and southern Africa ranges from ca. 800 to $470 \mathrm{Ma}$ (compilation in Meert, 2003). Three main frequency maxima of tectonic activity are apparent in the data, at ca. 760 to $730 \mathrm{Ma}, 660$ to $610 \mathrm{Ma}$ and 570 to $530 \mathrm{Ma}$, respectively. The third of these events is referred to as the "Kuunga orogeny" by Meert (2003).

Whole-rock geochemical analyses are reported in this publication. They are tabulated in Appendix 1 (or data repository attached to this article). Representative samples of the main magmatic suites and orthogneiss units of all mapped complexes were selected. They were analysed for major and trace elements using standard XRF techniques at the Geological Survey of Norway, Trondheim. Analyses were completed on a Philips X-ray Spectrometer PW 1480 with a Rh X-ray tube. Determination of major elements is performed on samples fused with $\mathrm{Li}_{2} \mathrm{~B}_{4} \mathrm{O}_{2}$ to glass beads, and trace elements on pressed pellets.

Since the 1970s, around 20 different classification schemes have been proposed for granitoids (see review in Barbarin, 1990), but no genetic scheme has gained universal acceptance. This reflects the hidden complexity resulting from a number of processes that can generate granitic magmas, resulting in their apparently simple mineral assemblages (e.g. see Introduction in Frost et al., 2001).

To describe the geochemistry of the magmatic rocks in the study area, we combine the use of the genetic S-I-M-A-system with the basically non-genetic and nontectonic classification proposed by Frost et al. (2001). Although the original concepts of S- and I-types are no longer valid, the terms are still commonly in use, and convey, in a simple manner, the overall geochemical properties of the rocks. The classification of Frost et al. (2001) is useful in the sense that it reflects the major chemical features relevant to granite mineralogy: silica, $\mathrm{Fe}-$ number $\left(\mathrm{FeO}^{\mathrm{tot}} /\left(\mathrm{FeO}^{\mathrm{tot}}+\mathrm{MgO}\right)\right)$, the modified alkalilime index MALI $\left(\mathrm{Na}_{2} \mathrm{O}+\mathrm{K}_{2} \mathrm{O}-\mathrm{CaO}\right)$ and Alumina Saturation Index ASI.

\section{Palaeoproterozoic foreland: Ponta Messuli Complex}

The Ponta Messuli Complex, which forms a small part of the foreland to the East African Orogen, is exposed along the shores of Lake Niassa, northwest of the Maniamba graben (Figure 1). It consists of partly migmatitic amphibolite- to granulite-facies orthogneiss, with minor amphibolite. It has been shown to be the oldest unit in northeastern Mozambique, giving a Palaeoproterozic metamorphic age of $1950 \pm 15 \mathrm{Ma}$, and characterized by the presence of detrital zircons older than $2074 \pm 11 \mathrm{Ma}$ (Bingen et al., 2009). Sm/Nd model ages indicate that Archaean material was involved in the formation of the complex (Saranga et al., DNG manuscript). The Ponta Messuli Complex is only weakly affected by Neoproterozoic-Cambrian (Pan-African) 

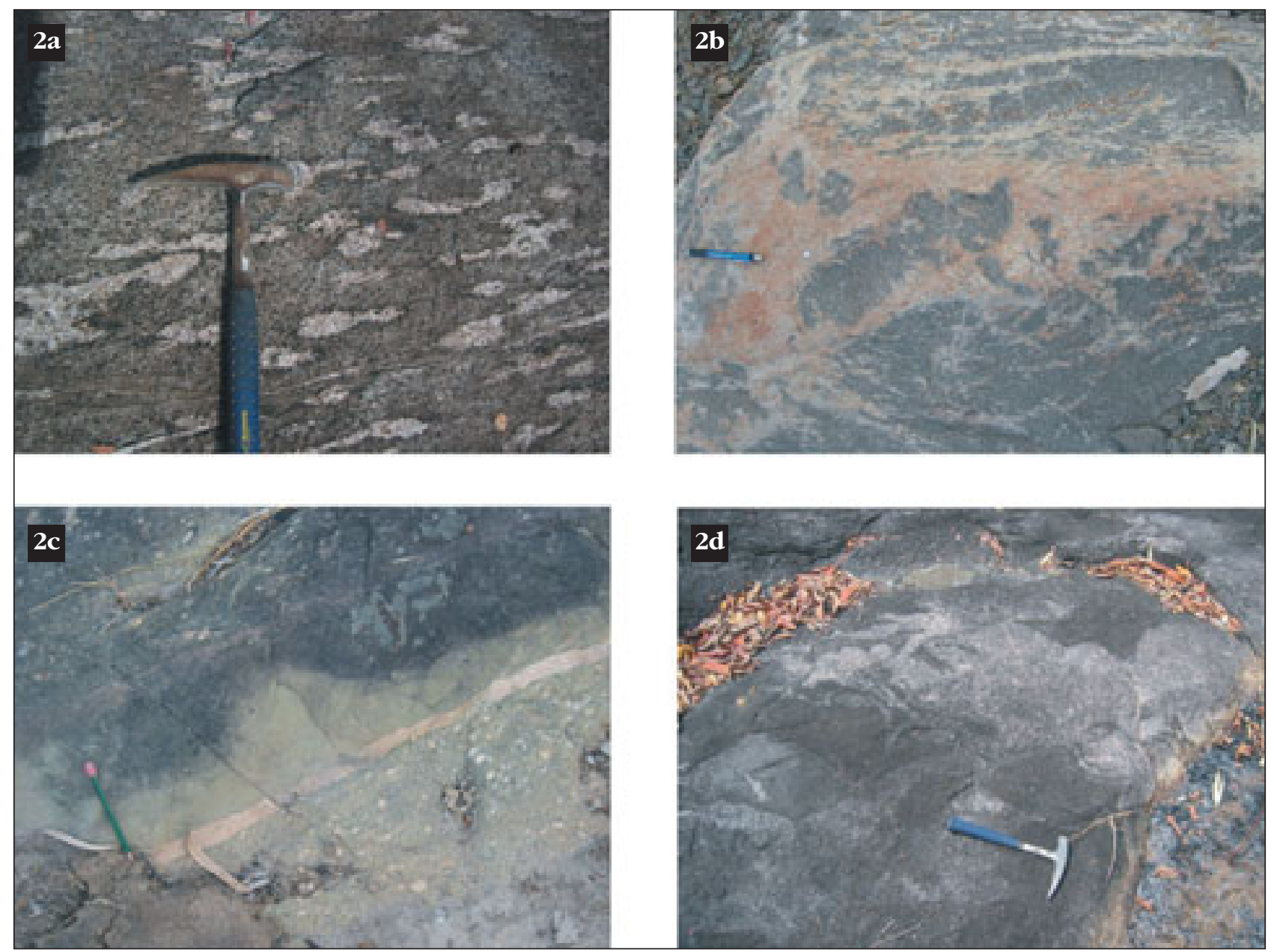

Figure 2. Unango Complex lithologies: (a) Patchy leucosomes in biotite-hornblende gneiss. (UTM 36S 737573, 8509000). (b) Migmatitic, enderbitic gneiss. Note early migmatitic banding (mesosome) truncated by later neosome. In quarry on road from Lichinga to Unango (UTM 36S, 738603, 8551456); (c) Composite monzogranitic (pink) and quartz monzodioritic (fine-grained greenish) dyke in porphyritic granodiorite. (UTM 365 798033, 8573363); (d) Magma mingling of monzo-granite (light grey) and quartz monzo-diorite (dark grey). Monzogranite north-northwest of the Chiconono granodiorite. (UTM 365 791805, 8655799).

metamorphism (Norconsult, 2007a; Viola et al., 2008). It is interpreted as a part of the Palaeoproterozoic foreland of the Pan-African East African Orogen (as shown, i.a. by Burke et al., 2003).

\section{Mesoproterozoic Unango Complex}

The Unango Complex forms most of the western part of Niassa Province and corresponds largely to the "Unango Group" of Pinna et al. (1993). It is exposed to the southeast of the Maniamba graben, and extends between the Tanzanian and Malawian borders (Figure 1). In the east, the Unango Complex is overthrust by the Marrupa Complex from the east and is overlain by a nappe sheet consisting of the Muaquia and M'Sawize Complexes (Figure 1). In the south, the Unango Complex is juxtaposed against the Nampula Complex along the Lurio Belt. The contact consists of a plexus of very poorly exposed, steep, east-northeasterly trending, anastomosing, shear zones of as yet unresolved kinematics, which is clearly seen on high-resolution aeromagnetic images.
The complex is dominated by intermediate to felsic orthogneiss, partly at granulite grade and partly- to completely retrogressed. Migmatisation of variable character is extensive. High-grade paragneisses locally predominate in the west, along the border with Malawi. The relative age relationship between the orthogneiss and supracrustal rocks cannot be established from field observations as many of the units in the complex are bounded by anastomosing shear zones.

\section{Supracrustal gneisses (including paragneisses) in the Unango Complex}

The Unango Complex includes isolated pods, lenses and bands of supracrustal gneiss of varied composition, typically enclosed within the voluminous intrusive orthogneiss. They include silicic rocks with undoubted sedimentary protoliths and various intermediate to basic layered gneisses of more debatable origin, which may have a mixed volcano-sedimentary parentage. Many gneisses of the latter type show granulitefacies assemblages. The most significant units which 
J. JACOBs, D. JAmal, G. MOTUZA, W. BAuER, E. DAudi, P. Feitio, V. MANhiCA, A. MONIZ AND D. ROSSE

were mapped at 1: 250000 scale are outlined in Table 1.

Rocks with clear sedimentary protoliths include "semipelitic" gneisses and migmatites, composed of interbanded felsic, garnetiferous biotite gneisses and sparse quartzites with darker hornblende gneisses, locally with graphite, outcropping, for example south of Lichinga, and called the Chala gneiss (e.g. Bloomfield et al. 1966; Andreoli 1984; Kröner at al. 2001). Other sequences contain rare bands of calc-silicate gneiss. Some quartzitic paragneiss units contain euhedral porphyroblasts of magnetite up to $1 \mathrm{~cm}$ in diameter. These rocks contain up to $75 \%$ quartz + K-feldspar in an equilibrium texture, testifying to a quartz-arenite parentage (magnetite-quartzite). Minor muscovitekyanite quartzites are also recorded near Lichinga.

Vestiges of typical granulite-facies characteristics such as dark feldspar and a clotted distribution of mafic minerals (e.g. McGregor and Friend, 1997) are found, testifying to the generally comparatively anhydrous nature of the Unango Complex. This is borne out by the presence of higher grade, granulite-facies assemblages within the supracrustal units, including mafic gneisses commonly containing orthopyroxene \pm clinopyroxene and felsic gneisses, also containing orthopyroxene. Migmatisation is variable, but locally intense, manifested as layer-parallel, stromatic leucosomes and several generations of crosscutting leucocratic veins. More diffuse nebulitic migmatites also occur, along with agmatites containing angular blocks of palaeosome in lower strain zones and rocks with a high degree of anatexis, resulting in diatexitic gneisses. Between the northern and southern parts of the Unango Complex there is a wedge of partly migmatitic biotite-hornblende gneiss (Meponda Gneiss) (Figure 2a), cut by anastomosing shear zones, within some of which thin lenses of ultramafic rock and of quartzite can be found.

\section{Orthogneisses in the Unango Complex}

Many of the orthogneiss suites of the Unango Complex are charnockitic (sensu lato). For example, the Lichinga Gneiss is an enderbitic to charnockitic granofels, which is partly migmatitic and which forms a major component in the complex north of Lichinga. The enderbites are typically homogeneous, equigranular rocks with a polygonal texture, composed of clinopyroxene, orthopyroxene, plagioclase and hornblende, with quartz that is locally blue in colour: their composition is, in general, monzodioritic. Rocks with a higher content of K-feldspar can be classified as mangerite (orthopyroxene-bearing monzonite) and, with higher quartz, charnockite (orthopyroxene-bearing granite). Red (highTi) biotite is always present, usually as a minor component and magnetite is the typical accessory phase. Retrogression and low-temperature deformation features occur locally. Natural outcrops tend to appear fairly homogeneous, but quarries show great heterogeneity, often with a high degree of migmatisation, with different types and phases of migmatite, including agmatites, (Figure 2b).

Some units (e.g. charnockitic gneiss, feldspar-phyric) are charnockites sensu stricto, with hornblende-biotite monzogranite composition and porphyroblastic with twinned K-feldspar augen and megacrysts up to $5 \mathrm{~cm}$ in size. Mafic mineral aggregates form clots including relict, altered orthopyroxene. In the Cuamba area, partly migmatitic charnockitic gneisses are equigranular and have a prominent gneissosity on a scale of 0.1 to $10 \mathrm{~cm}$, with mafic seams as well as quartz-feldspar- and quartzrich bands.

The Chiconono Gneiss, a feldspar-phyric granodioritic to monzonitic orthogneiss (Figure 2c), differs from the units described above, in showing a mineral paragenesis indicating greenschist facies over large areas. This unit shows a polyphase character with internal relationships including: (a) monzogranite xenoliths and veins and (b) composite monzogranitic and more mafic dykes, without chilled margins, in the granodiorite (Figure 2d). These age relationships imply that the various components of the igneous complex were emplaced broadly at the same time. Typical granitic to granodioritic gneisses occur south of Metangula and north of Lichinga, with augen gneisses developed in high-strain zones (e.g. in the Milanje area).

The monzogranitic orthogneisses are quartzofeldspathic, biotite-bearing and locally show iron mineralisation. Migmatisation is widespread, locally in two episodes, one pre- or syn-foliation and one postfoliation. Magnetite is common, in some localities in coarse pegmatite veins. These rocks are widely distributed throughout the Unango Complex, being also present farther south, in the Insaca-Guruè area, where charnockitic facies are also developed (characterized by white-weathering plagioclase mesocrysts up to $1 \mathrm{~cm}$ long on weathered surfaces). Foliation is invariably strong and locally proto-mylonitic, with ribbon quartz. Granular to layered mafic enclaves and schlieren containing biotite, hornblende and locally pyroxenes are common.

Table 2. Geochemical compositional ranges for the main lithological groups in the Unango Complex.

\begin{tabular}{lllll}
\hline $\begin{array}{l}\text { Unango Complex } \\
\text { main rock types }\end{array}$ & $\mathbf{S i O}_{\mathbf{2}}$ & $\mathbf{K}_{\mathbf{2}} \mathbf{O}$ & $\mathbf{M g \#}$ & $\mathbf{N}$ \\
\hline Granite & $65.9-78.4$ & $3.0-6.2$ & $0.01-0.30$ & 39 \\
\hline Granodiorite & $60.4-70.3$ & $1.6-5.1$ & $0.15-0.50$ & 24 \\
\hline $\begin{array}{l}\text { Syenite, quartz } \\
\text { syenite }\end{array}$ & $56.7-66.3$ & $4.4-8.2$ & $0.03-0.35$ & 11 \\
\hline $\begin{array}{l}\text { Monzodiorite, } \\
\text { monzonite, }\end{array}$ & & & & \\
q-monzonite & $47.6-59.9$ & $1.4-7.7$ & $0.07-0.49$ & 30 \\
\hline Gabbro, diorite, & & & & \\
quartz-diorite & $41.5-58.9$ & $0.2-2.3$ & $0.41-0.73$ & 13 \\
\hline Amphibolite & $43.1-46.3$ & $0.8-1.0$ & $0.46-0.51$ & 3 \\
\hline Dykes & $49.1-63.4$ & $2.2-3.9$ & $0.02-0.46$ & 4 \\
\hline
\end{tabular}




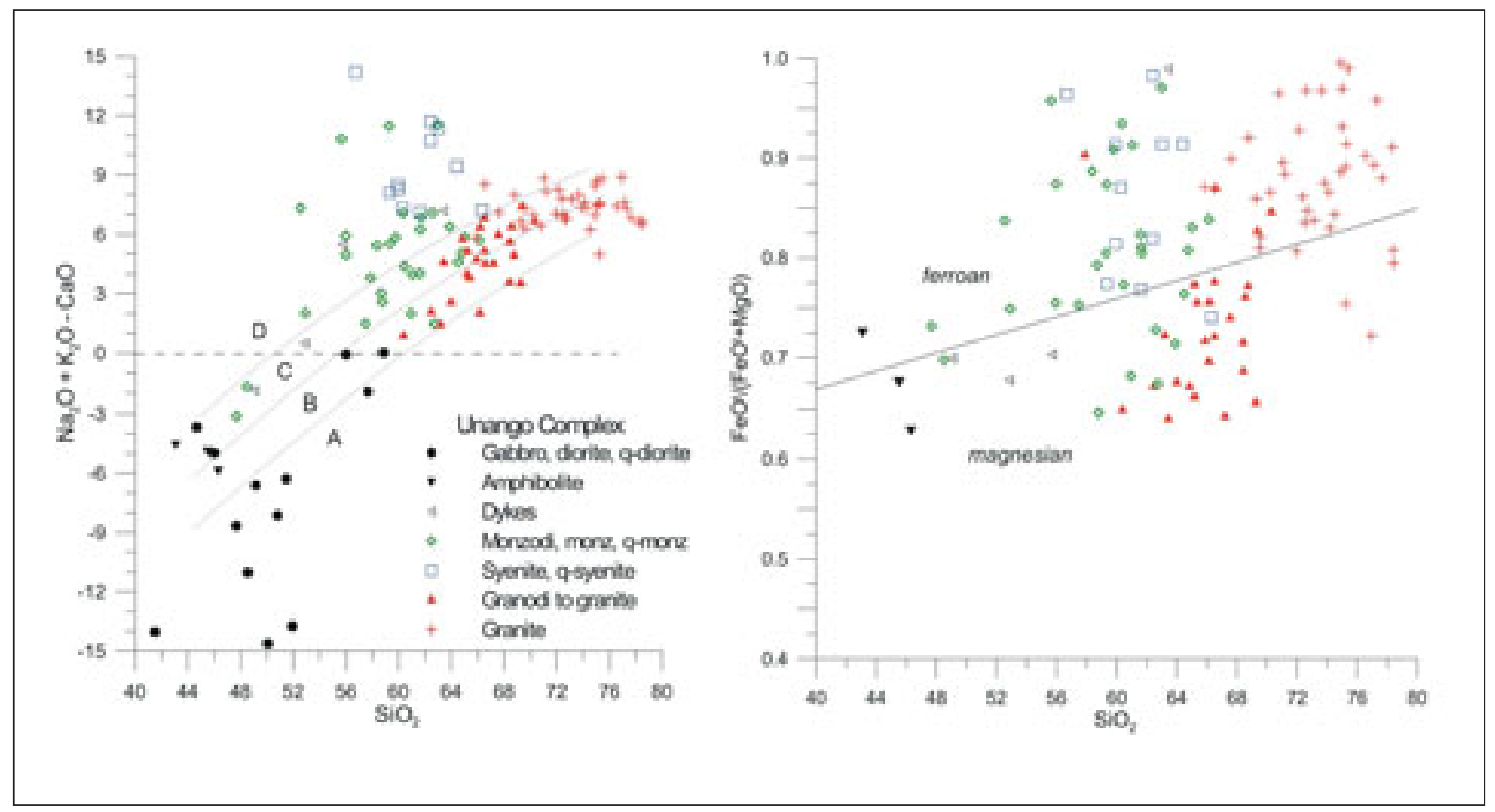

Figure 3. Modified alkali-lime index (left) plotted against $\mathrm{SiO}_{2}$ (weight \%) for rocks of the Unango Complex. The lines subdivide between calcic $(\boldsymbol{A})$, calc-alkaline $(\boldsymbol{B})$, alkali-calcic $(\boldsymbol{C})$ and shoshonitic $(\boldsymbol{D})$ rocks. Classification diagram (right) showing the subdivision of the rocks in magnesian (below) and ferroan (above). Granodioritic and more mafic rocks plot almost entirely to the magnesian field. A large proportion of monzonitic and syenitic rocks are ferroan. Diagrams from Frost et al. (2001)

Pale-weathering albite syenite orthogneisses form a small lithological unit north of Lago Ciuta on the border with Malawi. The rocks are mostly medium to coarsegrained and banded, composed of interlocking granofelsic feldspar with minor mafic minerals, biotite and magnetite. The syenite contains thin mafic layers with dark pyroxene-rich layers up to several dm thick, intercalated with feldspathic bands, which range in thickness from $1 \mathrm{~cm}$ to $1 \mathrm{~m}$. The mafic layers occur in groups, locally showing discordances, which possibly represent primary igneous layering.

The Meponda Gneiss is biotite-hornblende gneiss, which occupies a large area around Meponda. These rocks are generally highly deformed, foliated, folded and banded, with variations in the content of mafic and felsic minerals, defining the layering from $\mathrm{cm}$ to tens of metres in scale. Extensive horizons of metagabbro/mafic gneiss are present in the biotite gneiss, along with lenses and layers of granitic to granodioritic orthogneiss within this unit.

The Unango Complex contains minor bodies of mafic to ultramafic rock with igneous protoliths. Metagabbro is found west and northwest of the main road from Lichinga to Meponda. These rocks are typically fine- to medium-grained, with a weak foliation along the contacts with surrounding charnockitic gneisses, and with original ophitic textures commonly preserved. The rocks consist of clinopyroxene, orthopyroxene and plagioclase as major components, locally with amphibole in porphyroblasts up to 1 to $2 \mathrm{~cm}$ long, with accessory biotite, quartz, K-feldspar and titanite. Such rocks also occur as small, deformed pods and lenses in the southernmost part of the Unango

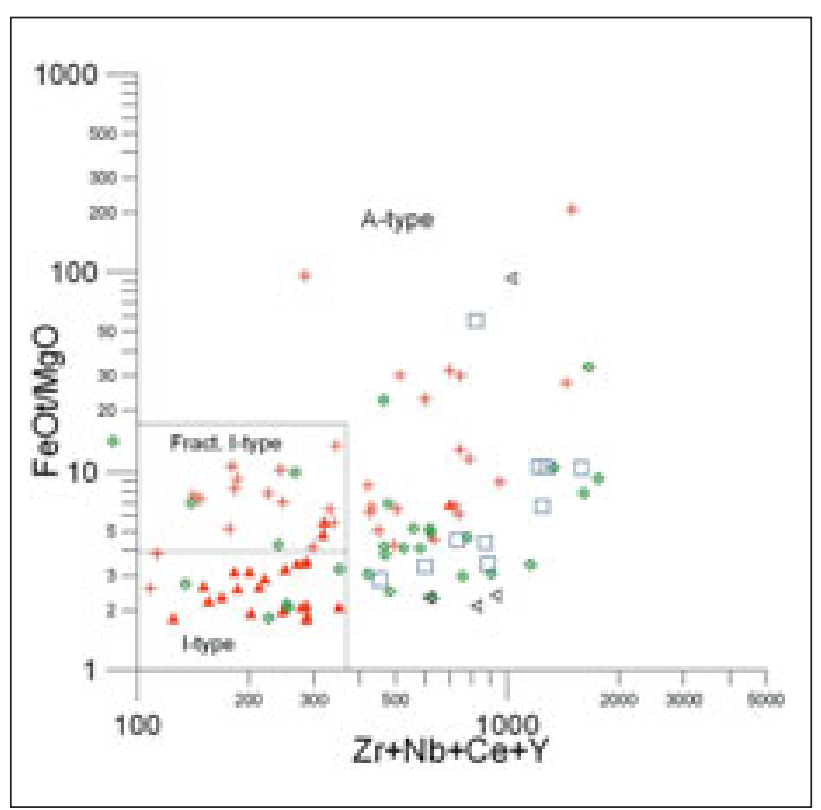

Figure 4. Total $\mathrm{FeO} / \mathrm{MgO}$ vs $\mathrm{Zr}+\mathrm{Nb}+\mathrm{Ce}+\mathrm{Y}$ (ppm), Unango Complex. Legend as in Figure 3. Granodiorites are classified as I-type rocks, whereas granites plot as fractionated I-type and A-type. Monzonitic rocks are mainly A-type. Syenitic rocks and acid dykes are uniformly A-type. Diagram from Whalen et al. (1987). 
R. BOyd, $\varnothing$. NOrdgulen, R.J. Thomas, B. BIngen, T. BJERKGÅrd, T. GRenne, I. Henderson, V.A. MELEZHik,

M OFTEN, JS. SANDSTAD, A SOLLI, E TVETEN, G VIOLA, R.M. KEY, R A SMITH, E GONZALEZ, LJ. HOLLICK, J. Jacobs, D. JAmal, G. motuza, W. BAuer, E. DAudi, P. Feitio, V. manhica, A. MOniz And D. ROsse
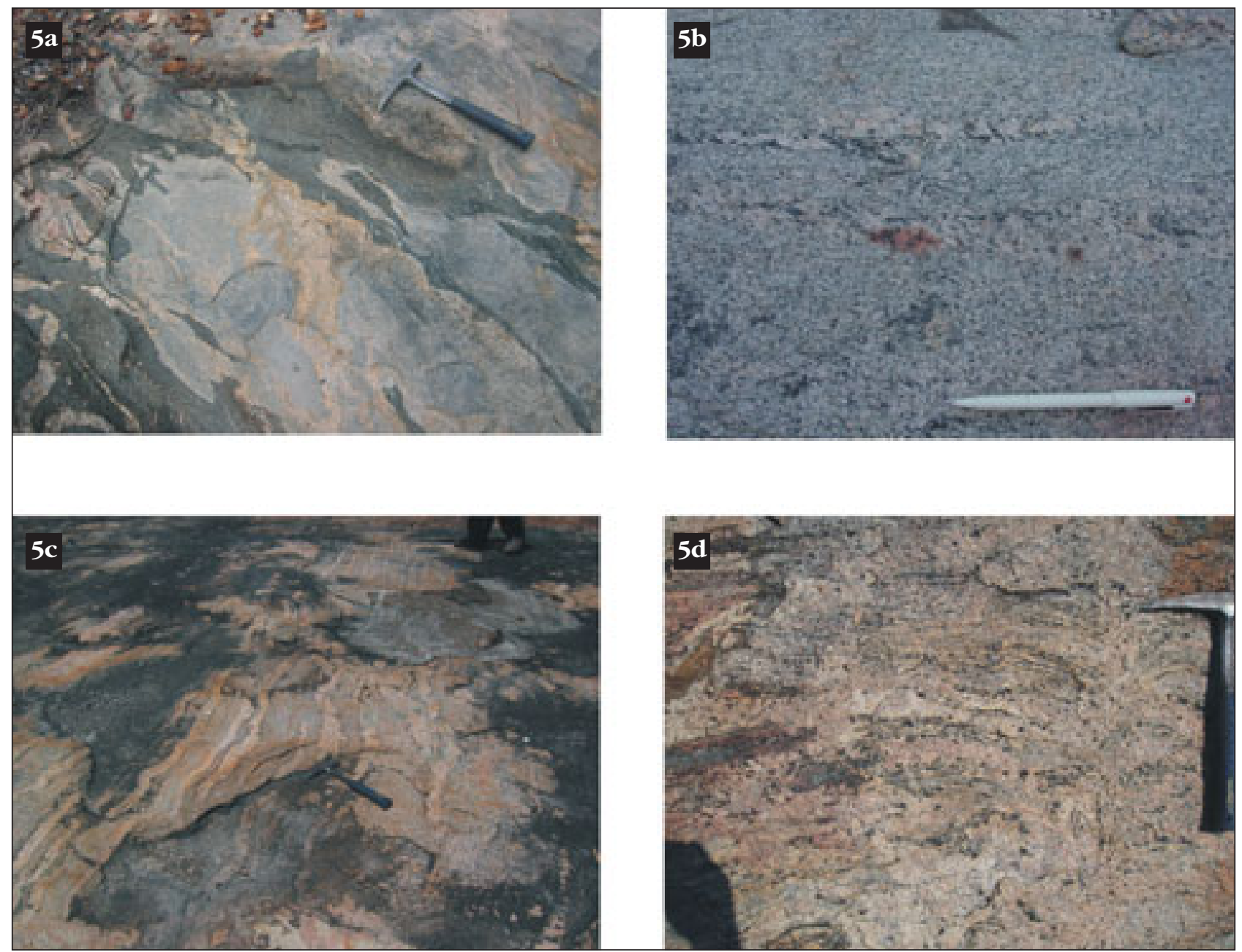

Figure 5. Marrupa Complex lithologies: (a) Migmatitic grey gneisses with disrupted mafic bands as well as two neosome phases. (UTM 37S, 267147 8362019); (b) Homogeneous facies of leucocratic hornblende-bearing granitic orthogneiss. Note heterogranular nature and characteristic dark speckled hornblende. (UTM 375326698 8383148). (c) Migmatitic, biotite-bearing, granodioritic gneiss with cm-dm thick leucocratic quartz-feldspar leucosomes. (UTM 375363766 8568146); (d) Amphibole-bearing diatexite. Note the very high proportion of diffuse, coarse-grained granitic leucosome (black spots are amphiboles), and darker palaeosome remnants of biotite-hornblende. (UTM 375331968 8431497).

Complex close to the border with Malawi. These are mainly coarse-grained, dark-grey metagabbros, though the status of some of the more banded amphibolites with which they are commonly associated is less certain.

In addition to metagabbros, ultramafic lenses are found, usually clearly associated with shear zones. Small lenses occur in major shear zones south and east of Lichinga, while more varied lithologies, in most cases also clearly linked to shear zones, are found to the south, in the region of the Lurio Belt (NampulaUnango Complex boundary) which is marked by a series of northeasterly trending anastomosing shear zones. The westernmost of these, entirely within the Unango Complex in the Milanje area, is associated with a line of poorly exposed tectonic pods and slivers of ultramafic-mafic rocks made up of a mixed assemblage of serpentinised peridotite and pyroxenite with subordinate melagabbro.
Orthogneisses from the Unango Complex yielded $\mathrm{U}-\mathrm{Pb}$ zircon intrusion ages between $1062 \pm 13$ and $949 \pm 11 \mathrm{Ma}$ (Bingen et al., 2009). The northwestern part of the Unango Complex is dominated by charnockitic to enderbitic rocks with variably retrogressed granulitefacies paragneisses. U-Pb data on zircon rims demonstrate that this metamorphism has an average age of $955 \pm 9 \mathrm{Ma}$ (Bingen et al., 2009). Some shear-bounded slices of granitic to granodioritic orthogneiss in the northeastern parts of the complex appear not to have exceeded amphibolite grade. They are typically strongly migmatised, suggesting high volatile activity. The area south of Lichinga is dominated by migmatised felsic to intermediate orthogneisses with a less obvious granulite-facies prehistory. U-Pb data on zircon and monazite indicate that the Pan-African metamorphic overprint, dated between $569 \pm 9$ and $527 \pm 8 \mathrm{Ma}$ (Bingen et al., 2009), becomes dominant in the area south of Lichinga. 


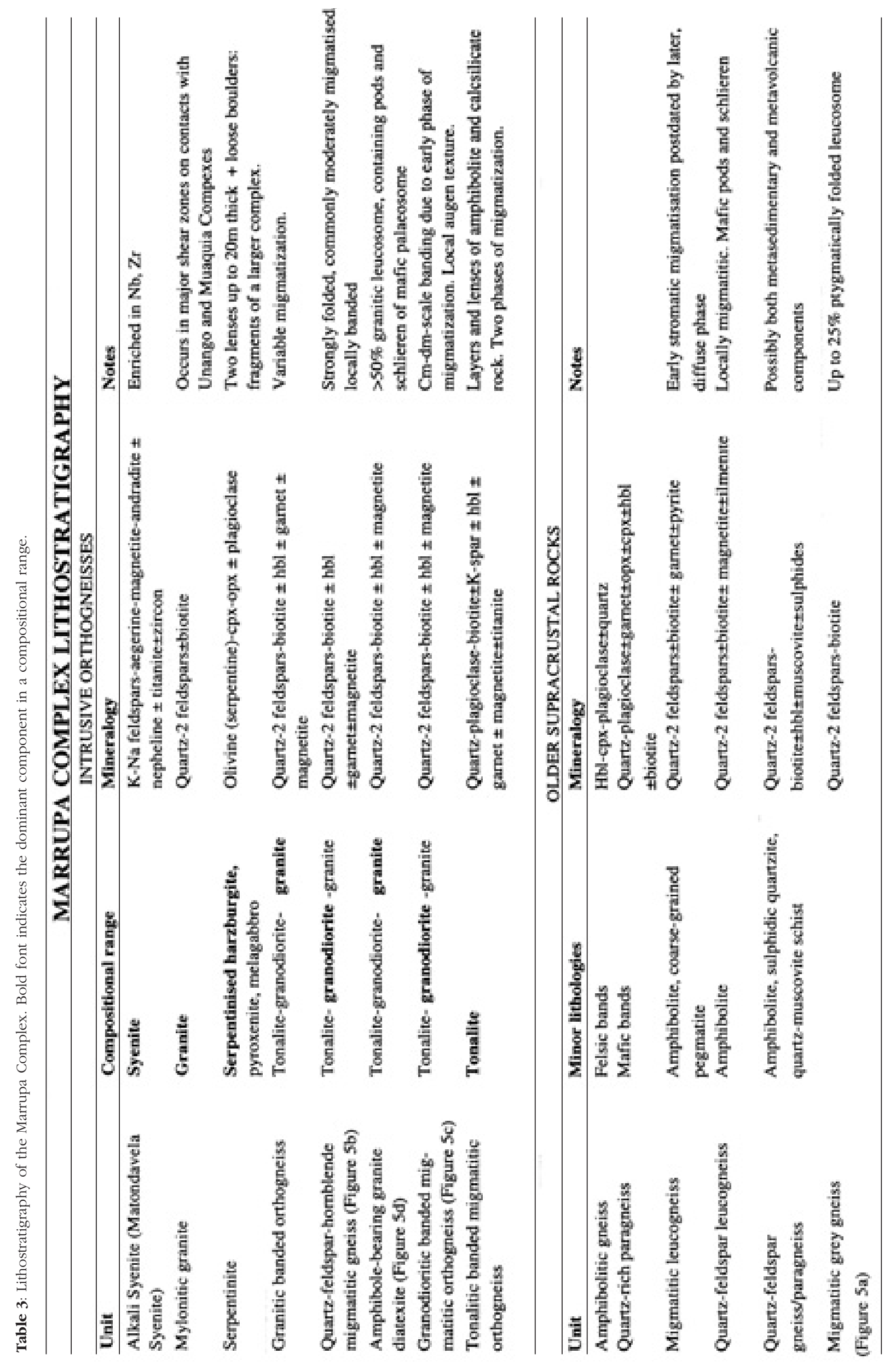




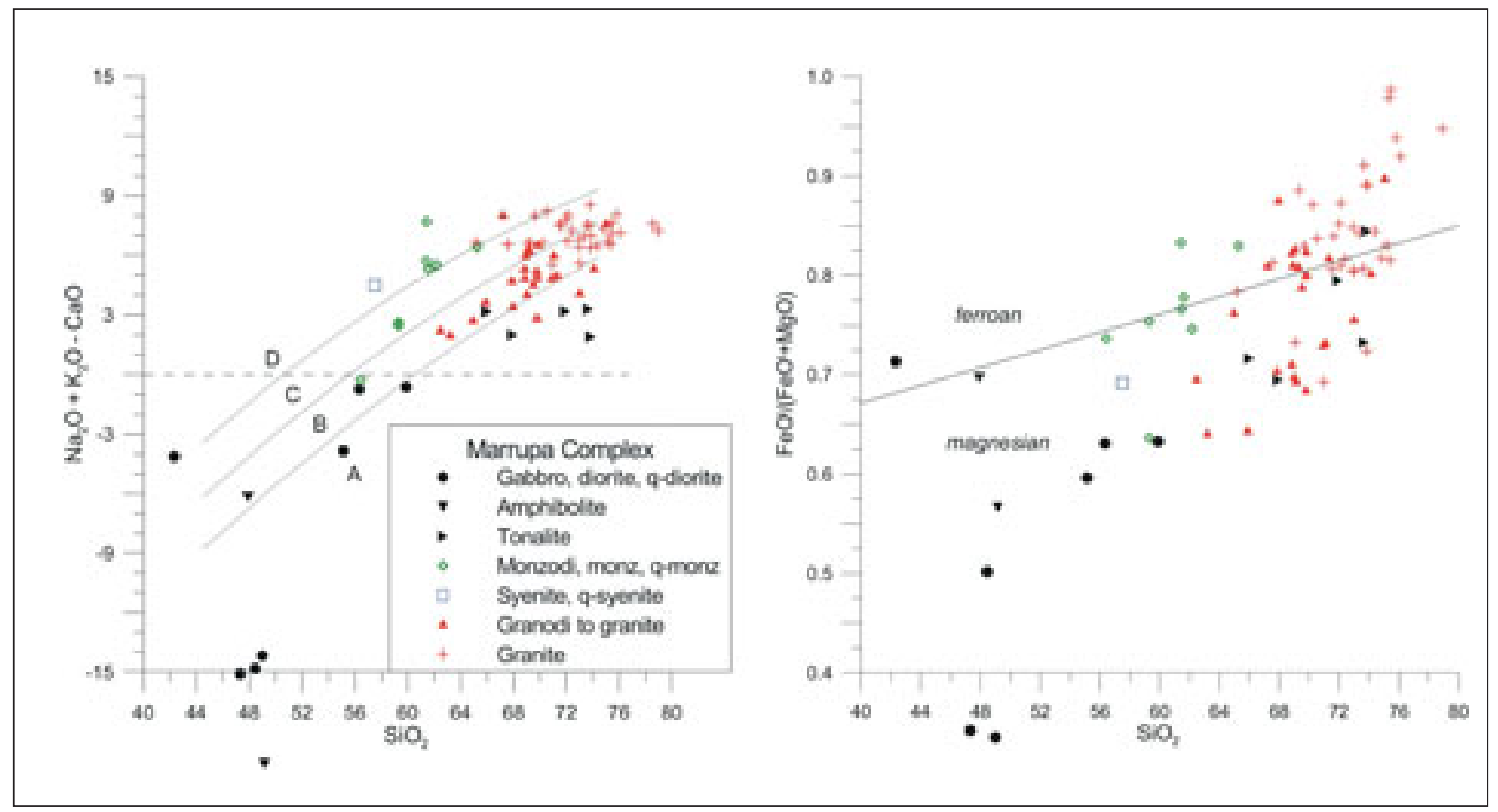

Figure 6. Modified alkali-lime index (left) plotted against $\mathrm{SiO}_{2}$ for rocks of the Marrupa Complex. The lines subdivide between calcic $(\boldsymbol{A})$, calc-alkaline $(\boldsymbol{B})$, alkali-calcic $(\boldsymbol{C})$ and shoshonitic (D) rocks. The monzonitic rocks and syenite have moderately high contents of alkalis and plot in the alkali-calcic to shoshonite fields. Note the calcic and magnesian nature of the tonalitic samples. Classification diagram (right) showing the subdivision of the rocks in magnesian (below) and ferroan (above). Diagrams from Frost et al. (2001).

\section{Geochemistry of the Unango Complex}

The mafic rocks of the Unango Complex, including gabbro, diorite and amphibolite, are metaluminous, lowto medium-K calc-alkaline rocks, with substantial variation in $\mathrm{Mg} \#$ (>0.4) (Table 2 ). Compared to the more evolved rocks, these are present in subordinate amount. A conspicuous feature of the complex is the absence of tonalite and low- to medium-K granodiorite. In contrast, there are abundant intermediate monzodioritic to monzonitic rocks. These rocks are alkali-calcic to shoshonitic, and a considerable proportion of the samples are ferroan (Figure 3). The group exhibits significant variation in minor and trace element contents. A number of samples have very high contents

Table 4. Geochemical compositional ranges for the main lithological groups in the Marrupa Complex.

\begin{tabular}{lcccr}
\hline Marrupa Complex & \multicolumn{1}{c}{$\mathbf{S i O}_{\mathbf{2}}$} & $\mathbf{K}_{\mathbf{2}} \mathbf{O}$ & $\mathbf{M g \#}$ & $\mathbf{N}$ \\
\hline Granite & $65.2-78.9$ & $3.8-6.1$ & $0.09-0.44$ & 33 \\
\hline Granodiorite & $62.5-71.3$ & $2.1-5.2$ & $0.27-0.50$ & 25 \\
\hline $\begin{array}{l}\text { Syenite, quartz } \\
\text { syenite }\end{array}$ & 57.5 & 6.4 & 0.44 & 1 \\
\hline $\begin{array}{l}\text { Monzodiorite, } \\
\text { monzonite, }\end{array}$ & & & & \\
q-monzonite & $56.4-65.3$ & $2.9-5.7$ & $0.26-0.50$ & 7 \\
\hline Tonalite & $66.0-73.9$ & $0.9-1.7$ & $0.25-0.44$ & 5 \\
\hline Gabbro, diorite, & & & & \\
quartz-diorite & $42.3-59.9$ & $0.2-2.1$ & $0.42-0.78$ & 7 \\
\hline Amphibolite & $47.9-49.2$ & $0.3-0.6$ & $0.44-0.58$ & 2 \\
\hline
\end{tabular}

of e.g. Sr, $\mathrm{Zr}$ and $\mathrm{Ba}$. Note that the samples of dykes are alkali-calcic and ferroan and plot close to the monzonitic rocks in most diagrams.

Granodioritic rocks are generally metaluminous to weakly peraluminous and high-K calc-alkaline with $\mathrm{Mg} \#$ at 0.15 to 0.50 . The rocks are generally more evolved than the monzodioritic to monzonitic rocks, and have lower contents of $\mathrm{K}_{2} \mathrm{O}$ and total alkalis, and higher $\mathrm{CaO}$ at similar $\mathrm{SiO}_{2}$ values. Using the classification of Frost et al. (2001), the rocks are calc-alkaline to alkali-calcic and mainly magnesian although a few samples stand apart having a clearly ferroan signature (Figure 3). The trace elements are characterized by moderate contents of LREE and HFS-elements. The rocks have moderate to fairly high contents of $\mathrm{Sr}(<600 \mathrm{ppm})$ and moderate to low $\mathrm{Zr}$, whereas the contents of $\mathrm{Rb}$ and $\mathrm{Ba}$ vary considerably. Trace-element contents are consistent with normal I-type composition although one sample with anomalously high Zr content (sample 31223, UTM $36 \mathrm{~S} 814130,8481778$ ) plots in the A-type field (Figure 4). The granites (ss) form a diverse group of high-K calkalkaline rocks with notable variation in $\mathrm{Mg} \#(0.01-0.30)$. The rocks are metaluminous to weakly peraluminous with alumina saturation index ranging from 0.92 to 1.13 . The majority of the rocks are ferroan (Figure 3 ). Trace-element contents are variable and a great proportion of the samples have moderate to low contents of LIL (e.g. Rb, Sr, Ba) and HFS elements. About $50 \%$ of the samples have elevated contents of $\mathrm{Zr}$ and/or light rare earth (LRE) elements and plot in the A-type 
field of Figure 4. The remaining samples plot in the field of fractionated I-type granites consistent with the ferroan nature of the rocks.

The rocks classified as syenites and quartz syenites are shoshonitic and mainly ferroan (Figure 3) with very high contents of alkalis and low $\mathrm{CaO}$. The rocks display variable contents of $\mathrm{TiO}_{2}$ and $\mathrm{P}_{2} \mathrm{O}_{5}$, but the spread in these elements is less pronounced than for the monzonitic rocks. The LIL and HFS elements also show great variation in abundance. As for the monzonitic rocks, several samples have strongly elevated contents of e.g. Sr, $\mathrm{Zr}$ and $\mathrm{Ba}$. The compositionally distinct groups are quite well illustrated in Figure 4. The diagram shows that the granodioritic rocks plot mainly in the field of I-type granites, about 50\% of the granites have compositions similar to fractionated I-type rocks, whereas other granites plot in the A-type field together with syenitic rocks. Note that the monzodioritic to monzonitic rocks plot in the fields of both the fractionated I-type and the A-type granites. Dyke rocks have consistently high contents of HFS-elements and plot in the A-type field.

\section{Marrupa Complex}

The Marrupa Complex lies east of the Unango Complex and is terminated in the south by the Lurio Belt (Figure 1). It corresponds largely to the "Marrupa antiform" or "Marrupa Group" of Pinna \& Marteau (1987) and Pinna et al. (1993), which they correlated

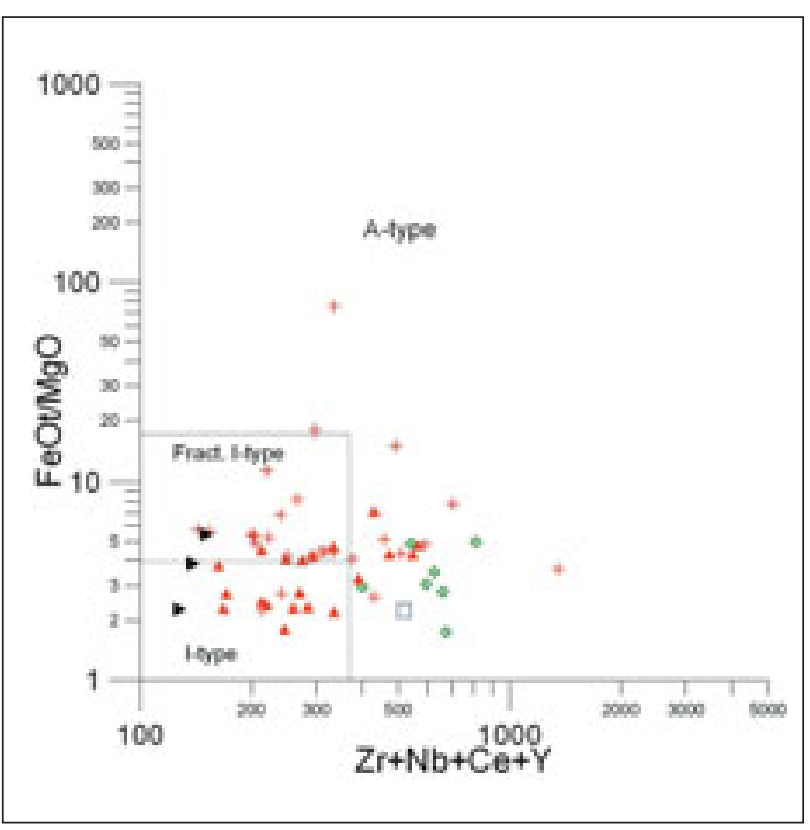

Figure 7. Total $\mathrm{FeO} / \mathrm{MgO}$ vs $\mathrm{Zr}+\mathrm{Nb}+\mathrm{Ce}+\mathrm{Y}$ (ppm) for rocks of the Marrupa Complex. Legend as in Figure 6. The tonalitic and magnesian granodioritic rocks plot mainly in the field of I-type granite although some granodiorites are in the A-type field. The granites plot in all the fields of the diagram, however, about $30 \%$ of the granites plot in the A-type field together with monzonitic and syenitic rocks. Diagram from Whalen et al. (1987). with their "Nampula Group", south of the Lurio Belt. The complex (Table 3) is dominated by felsic to intermediate orthogneisses (Figures 5a, b, c). Mafic orthogneisses are subordinate, and paragneisses of sedimentary origin are much less common than in the Nampula and Unango Complexes (see Table 4). The gneisses vary from homogeneous and rather finegrained (Figure 5b), to more coarse-grained, and include banded and migmatitic varieties (Figures 5c, d) with biotite-hornblende-bearing assemblages indicative of amphibolite facies metamorphism. The intrusion age of the orthogneiss ranges from $1026 \pm 9$ to $946 \pm 11 \mathrm{Ma}$ (7 samples; Norconsult 2007a; Bingen et al., 2009) and timing of metamorphism is constrained by U-Pb dates on zircon rims and monazite at $555 \pm 11 \mathrm{Ma}$ (average of five samples, Bingen et al., 2009).

\section{Geochemistry of the Marrupa Complex}

The mafic rocks, together with tonalitic rocks, make up a group of essentially low-K calcic to calc-alkaline, magnesian rocks (Table 4, Figure 6). Metaluminous tonalites and more mafic rocks make up about $15 \%$ of the samples. Monzodioritic to monzonitic rocks are represented by a few samples, and only one sample of syenitic composition was taken. These rocks are alkalicalcic to shoshonitic and straddle the boundary between magnesian and ferroan (Figure 6). Weakly peraluminous granites and granodiorites are clearly the predominant rocks in the complex. The granodiorites appear to make up two subgroups. One group consists essentially of magnesian medium-K calc-alkaline rocks, and the other includes magnesian to ferroan, high-K calc-alkaline rocks.

The trace-element contents for the rocks are highly variable for many elements. The Sr contents illustrate this quite well, showing a wide range of values for all rock groups. The mafic to intermediate rocks including tonalites have fairly low contents of $\mathrm{Rb}, \mathrm{Ba}$ and $\mathrm{Zr}$ as well as LREE. As expected, the magnesian granodiorites have lower $\mathrm{Rb}$ contents than other granodiorites; however, the range in $\mathrm{Rb}$ and $\mathrm{Ba}$ contents is substantial for these rocks. In general, the trace-element contents are consistent with the main components and suggest that the Marrupa Complex comprises different rock types including normal and fractionated I-type granites in addition to rocks with a clear A-type affinity (Figure 7).

\section{Nairoto Complex}

The Nairoto Complex is exposed in the northeastern part of the mapped area and is dominated by felsic orthogneisses. From near Mueda to Montepuez (Figure 1) the complex strikes north-northeast to south-southwest and has a width of 15 to $30 \mathrm{~km}$ (Figure 1). North of Montepuez there is a major fold, with an axial plane trending north-northeast to south-southwest that rotates the southeastern extension of the unit to a west-northwest to east-southeast trend, forming a 10 to $15 \mathrm{~km}$ wide belt which extends towards Mecufi where it is overlain by the Rovuma Basin. 
M. OFTEN, J.S. SANDSTAD, A SOLU, E. TVETEN, G. VIOLA, R.M. KEY, R A SMITH, E. GONZALEZ, LJ, HOLULK, J. Jacobs, D. JAmal, G. motuza, W. BAuer, E. DAudi, P. Feitio, V. manhica, A. Moniz And D. Rosse

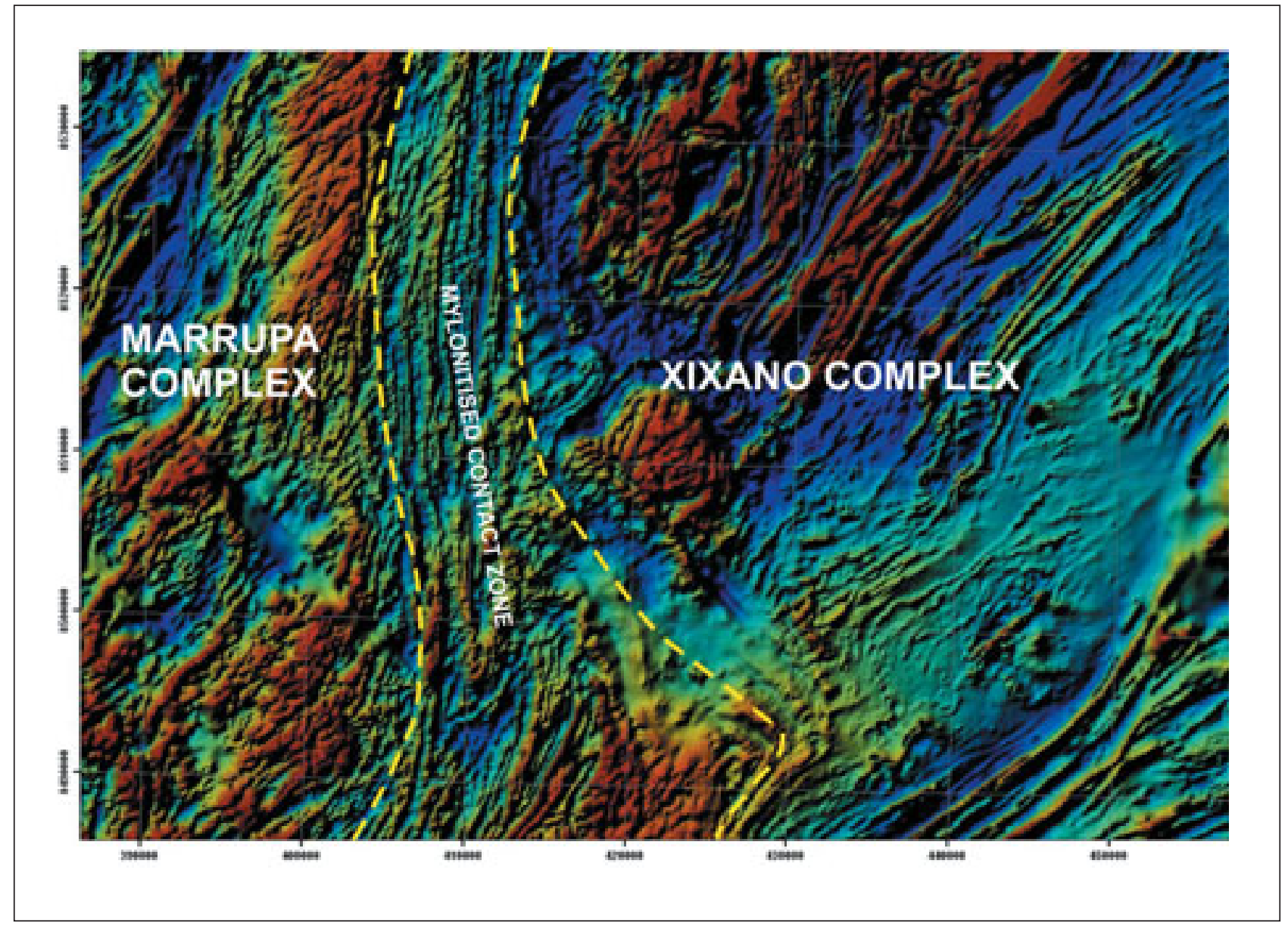

Figure 8. Aeromagnetic map showing the contact zone between the Marrupa and Xixano Complexes. A 10 km wide zone of sheared rock occurs at the contact on which Xixano Complex meta-supracrustal rocks are tectonically juxtaposed with the Marrupa Complex.

The complex thus comprises an arc-shaped belt wrapped around the Lalamo Complex, the contacts with which are clearly tectonic. The orthogneisses that form the complex are commonly magnetite-bearing, and the belt shows pronounced positive aeromagnetic anomalies.

The term Nairoto was introduced by Pinna et al. (1993) who gave the unit group status even though they realized that its components were mainly metamorphosed intrusive rocks. They correlated the Nairoto Complex with the Meluco and Marrupa Complexes (our usages) as part of a basement mega-unit (their Nampula Supergroup) onto which their Chiure Group was thrust. Geochronological data reported by Jamal et al. (2005) are compatible with the correlation between the Nairoto and Marrupa Complexes. The Nairoto Complex consists predominantly of locally migmatised felsic orthogneisses. These rocks are calcalkaline, with predominantly granodioritic and tonalitic compositions and minor granitic components, and can be classified as normal I-type granitoids. There are no indications that the metamorphic grade exceeded amphibolite facies.

Variations in migmatisation and composition are seen clearly in east-west profiles north and south of Rio
Messalo (Figure 1). All textural variations from granitic gneiss with a weak foliation, to multiply-folded migmatites are seen. The typical granitoid gneiss is well foliated, fine- to medium-grained and contains biotite. Pegmatitic veins and patches are common. Irregular biotite-rich lenses, inclusions and bands commonly occur in the migmatitic granitic gneiss and migmatites. The orthogneiss contains thin lenses of fine-grained $(\leq 1 \mathrm{~mm})$, granular, greyish-white to red metaarkose with a weak foliation, generally defined by biotite. The typical granitic migmatite is banded, and is locally intensely folded.

\section{Meluco Complex}

The Meluco Complex occurs in two large, oval, domelike structures (measuring $30 \times 50 \mathrm{~km}$ and $45 \times 60 \mathrm{~km}$ ) southeast of Meluco (Figure 1). The main part of the Meluco Complex was earlier called the Meluco Group, and was, together with other high-grade orthogneiss units, assigned to the Nampula Supergroup (Pinna and Marteau, 1987). These high-grade units were interpreted by Jourde and Wolff (1974) as an old migmatitic basement, considered to have been extensively reworked by the ca. 1000 Ma "Lurian Orogeny". According to Pinna et al. (1993), the Meluco Group 

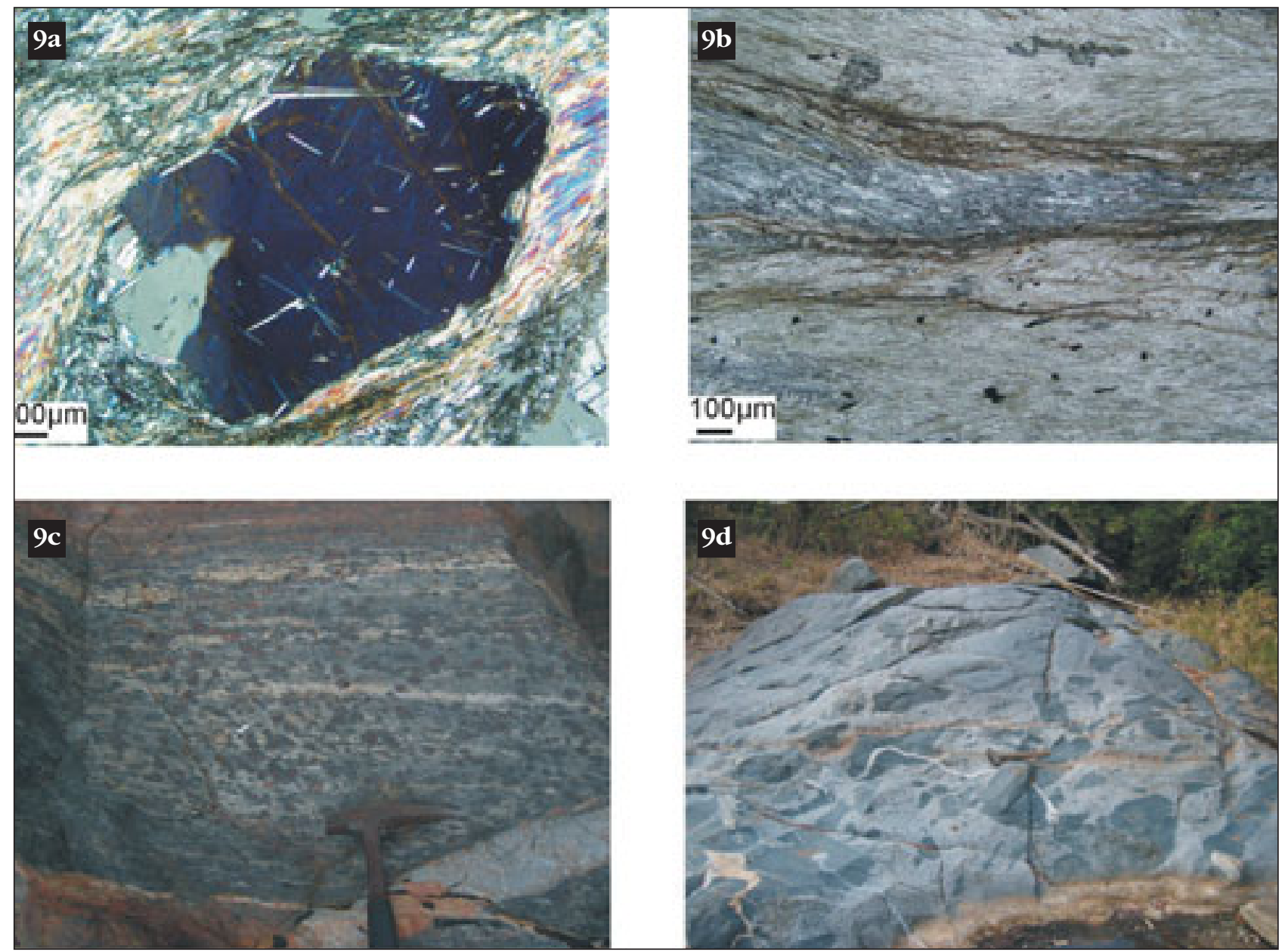

Figure 9. Xixano Complex lithologies: (a) Quartz mica schist, showing quartz porphyroclasts with unoriented needles of sillimanite, relics of a high-grade event, and (b) Chlorite-rich shears in a muscovitic groundmass testifying to greenschist-facies overprinting on focused shear planes. (UTM 375 470800, 8503702); (c) Banded amphibolitic gneiss with garnets up to 1 to $2 \mathrm{~cm}$ in diameter. (UTM 375 442660, 8733158); (d) Xenoliths of meta-gabbro in quartz diorite (UTM 375 459212, 8658780).

represents polyphase batholiths emplaced in the deep part of a mature island arc or active continental margin. The Meluco Complex consists of granitic to granodioritic orthogneisses, with subordinate tonalitic gneiss. The complex and convoluted magnetic and radiometric signatures of the complex are characterised by a rather irregular, folded pattern, in contrast to the supracrustal rocks in the surrounding Lalamo Complex, which define a clearly banded pattern that wraps around the Meluco Complex in a concentric fashion. The thesis that the Meluco Complex is a basement for the supracrustal rocks is therefore plausible, but unproven. The contact with the Lalamo Complex, at the only locality where it has been observed (UTM 375557097 , 8612382), is a thrust, with the rocks of the Lalamo Complex thrust over the Meluco Complex in a "top-tothe-south" sense. Granitic gneiss from the eastern dome yields an intrusion age of $946 \pm 12 \mathrm{Ma}$ (Norconsult 2007a). An equivalent age is obtained from one sample of the western dome (Jamal, 2005). Four samples of granodioritic/granitic gneiss from the Meluco Complex have been analysed by XRF, and indicate a high-K calcalkaline character for the complex; they can be classified as fractionated I-type granitoids.

The gneisses are coarse-grained, with generally quartz-rich assemblages that include plagioclase, K-feldspar, biotite and hornblende \pm red garnet and opaque minerals. The migmatitic textures vary from stromatic to coarser fabrics with sharply defined, thicker neosome layers up to tens of $\mathrm{cm}$ in thickness, to multiphase, complex migmatites with disrupted mafic bands invaded by granitic partial-melt patches and with mafic (restite) lenses surrounded by rock rich in granitic neosome veins and patches. The gneissosity becomes diffuse where there is extensive partial melting. There are also thick $(>10 \mathrm{~m})$ granite sheets concordant with the gneissosity.

\section{Xixano Complex}

The Xixano Complex is characterized by a highly distinctive, mainly weak radiometric signature on new high-resolution airborne geophysical data which has 


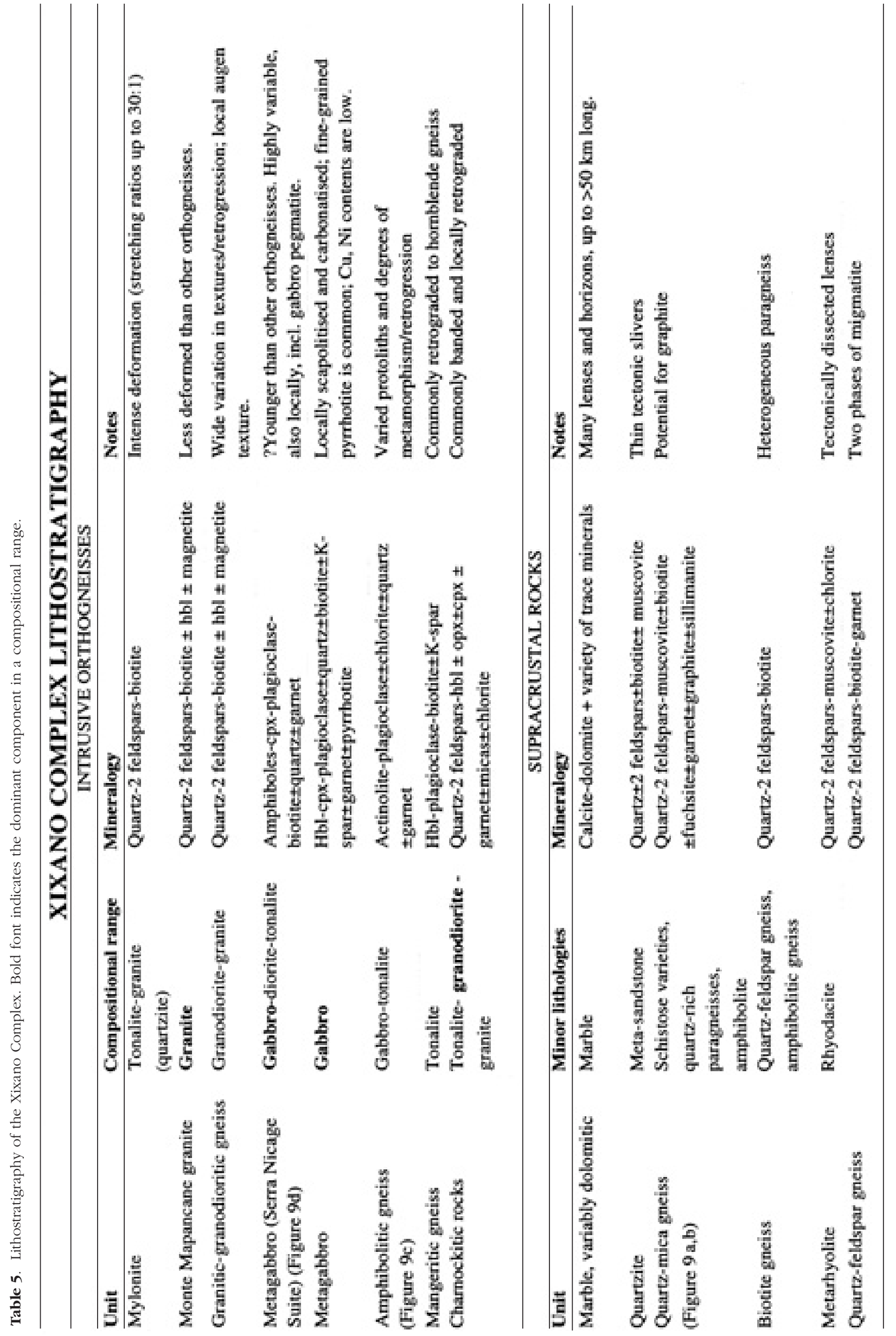


facilitated its recognition as a new tectonostratigraphic unit (Norconsult 2007b; Viola et al., 2008). It extends to the south-southwest from the Tanzanian border, east of Rio Lugenda to the Lurio Belt. The Xixano Complex overlies the Marrupa Complex, including two newly recognized tectonic outliers (a large, north-southtrending klippe near Nipepe and a smaller one to the west, Figure 1) (Viola et al., 2008). The complex includes parts of the Chiure and Morrola Groups, as defined by Pinna and Marteau (1987), who attributed them to the Chiure and Lurio Supergroups respectively. The contact between the Xixano Complex and the Marrupa Complex in the west is a major shear zone, interpreted as a thrust (Figure 8, Viola et al., 2008) that

Table 6. Geochemical compositional ranges for the main lithological groups constituting the Xixano Complex.

\begin{tabular}{llllr}
\hline Xixano Complex & SiO2 & K2O & Mg\# & N \\
\hline Granite & $68.8-77.7$ & $3.9-5.7$ & $0.03-0.48$ & 11 \\
\hline Granodiorite & $69.7-72.7$ & $2.5-4.5$ & $0.22-0.33$ & 3 \\
\hline $\begin{array}{l}\text { Monzodiorite, } \\
\text { monzonite, }\end{array}$ & & & & \\
Quartz monzonite & 49.8 & 2.0 & 0.49 & 1 \\
\hline Tonalite & $57.8-72.1$ & $0.2-1.3$ & $0.21-0.52$ & 8 \\
\hline Gabbro, diorite, & & & & \\
quartz-diorite & $41.2-50.4$ & $0.1-0.3$ & $0.4-0.72$ & 8 \\
\hline Amphibolite & $43.9-60.2$ & $0.1-0.4$ & $0.22-0.72$ & 4 \\
\hline Metavolcanic rocks & $51.1-76.4$ & $0.1-0.4$ & $0.22-0.72$ & 7 \\
\hline
\end{tabular}

was subsequently folded against the Lurio Belt in the south. The shear-zone contact with the Montepuez Complex in the east is also strongly folded. A major shear zone also separates the Xixano Complex from the Nairoto Complex in the east.

The Xixano Complex (Table 5) includes a variety of metasupracrustal rocks (Figures 9a, b) enveloping predominantly mafic igneous rocks and granulites (Figures 9c, d) that form the core of a regional north-northeast to south-southwest-trending synform. The paragneisses include mica gneiss and schist, quartzfeldspar gneiss, metasandstone, quartzite and marble. Felsic orthogneisses occur with the paragneisses, mainly in northern and eastern areas. The metamorphic grade in the paragneiss is dominantly amphibolite facies, although granulite-facies rocks are locally preserved within tectonic lenses.

The oldest dated rock in the Xixano Complex is a weakly deformed metarhyolite, which is interlayered in the metasupracrustal rocks and which gives a reliable extrusion age of $818 \pm 10 \mathrm{Ma}$ (Norconsult 2007a). Marble horizons, also interlayered with supracrustal rocks, have apparent deposition ages, as estimated by chemostratigraphic methods, of 850 to $750 \mathrm{Ma}$ in the north of the Xixano Complex and ca. $740 \mathrm{Ma}$ in the south (Melezhik et al., 2008). A meta-igneous granulite (enderbite) yielded a younger intrusion age of $744 \pm$ $11 \mathrm{Ma}$ (Norconsult 2007a). Available geochronology thus demonstrates that the bulk of the Xixano Complex is

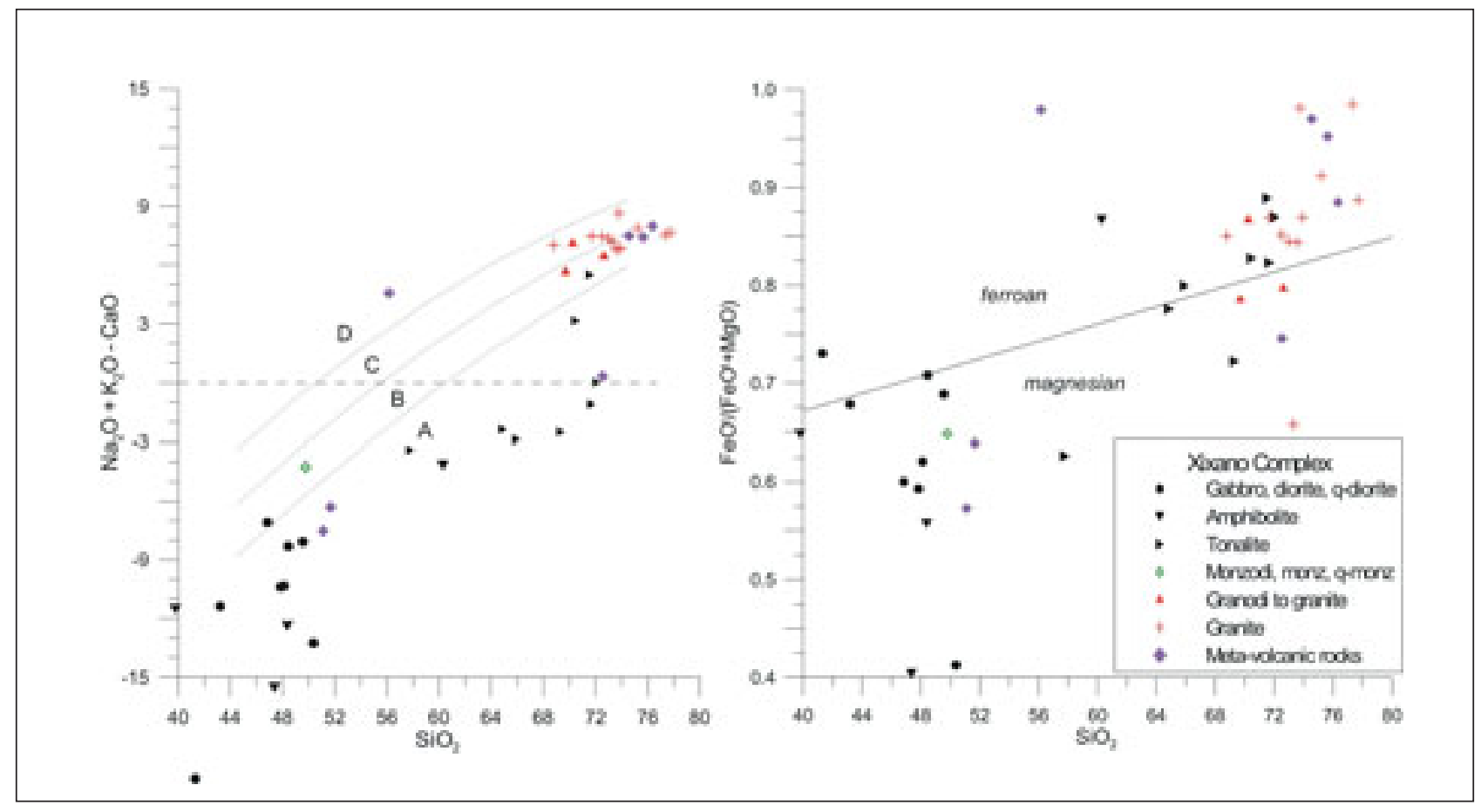

Figure 10. Modified alkali-lime index (left) plotted against $\mathrm{SiO}_{2}$ for rocks of the Xixano Complex. The lines subdivide between calcic (A), calc-alkaline (B), alkali-calcic (C) and shoshonitic (D) rocks. Note the low contents of total alkalis for the mafic to intermediate rocks. Classification diagram (right) showing the subdivision of the rocks in magnesian (below) and ferroan (above). In the Xixano Complex, granitic rocks and some the evolved tonalites plot above the line and classify as ferroan. Diagrams from Frost et al. (2001). 
R. BOyd, $\varnothing$. NORdgulen, R.J. ThOMAs, B. BINGEN, T. BJERKGÅRd, T. GRENNE, I. HENDERSON, V.A. MELEZHIK,

M. OFTEN, J.S. SANDSTAD, A. SOLLI, E. TVETEN, G. VIOLA, R.M. KEY, R. A. SMITH, E. GONZALEZ, L.J. HOLLICK, J. JACOBs, D. JAmal, G. MOtuza, W. BAuER, E. DAudi, P. Feitio, V. manhiCA, A. MONiz AND D. ROSse

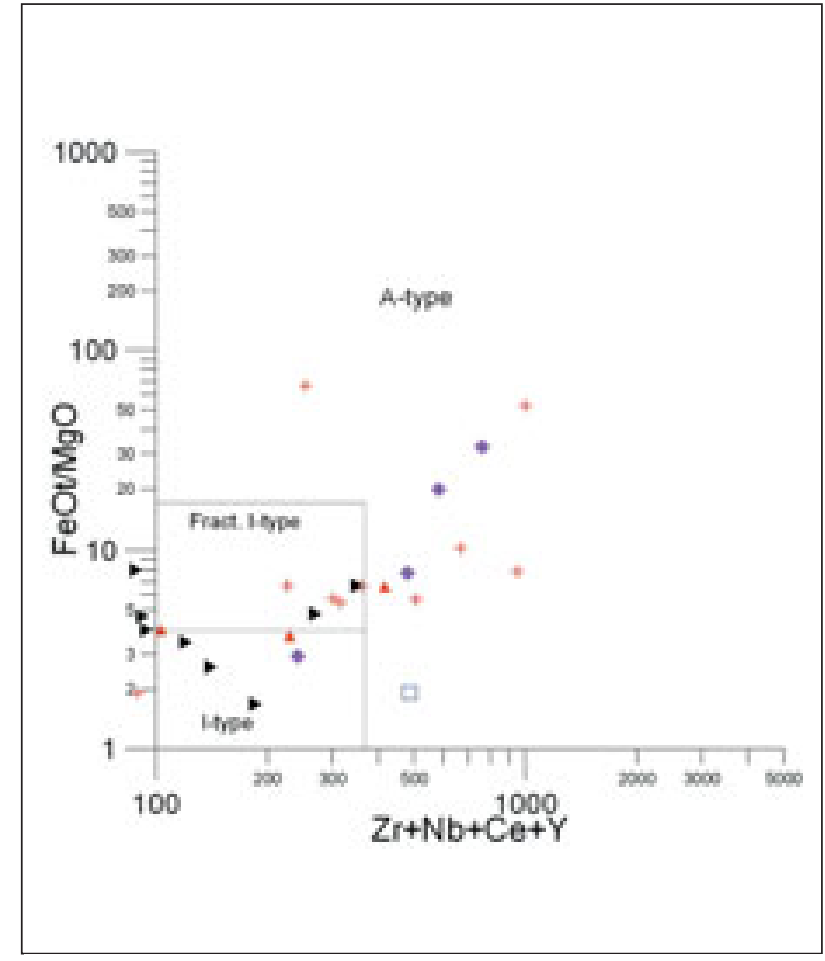

Figure 11. Total $\mathrm{FeO} / \mathrm{MgO}$ vs $\mathrm{Zr}+\mathrm{Nb}+\mathrm{Ce}+\mathrm{Y}$ for rocks of the Xixano Complex. Legend as in Figure 10. The granitic and granodioritic rocks plot mainly in the field of fractionated I-type granite and into the A-type field. The same is the case for the volcanic rocks. Tonalites plot in the I-type field. Diagram from Whalen et al. (1987).

made up of Neoproterozoic lithologies formed between 820 and $740 \mathrm{Ma}$.

\section{Geochemistry of the Xixano Complex}

The Xixano Complex (Table 6) is mainly composed of mafic to felsic low-K magnesian rocks with very few samples of intermediate composition. Predominant rocks types are calcic, mafic gabbro and diorite and low$\mathrm{K}$ tonalite. The evolved rocks are mainly high-K calcalkaline granite and granodiorite and plot in the ferroan field of Figure 10. Some samples of metavolcanic rocks are compositionally similar to the intrusive rocks. Apart from one sample of monzodiorite, monzonitic and syenitic rocks are notably absent in the Xixano Complex. The diagrams also show some samples of metavolcanic rocks. Apart from one shoshonitic sample, the volcanic rocks are compositionally very similar to the gneisses of intrusive origin.

The contents of LIL- and HFS-elements are low in the mafic rocks. This is particularly the case for $\mathrm{Rb}$ and $\mathrm{Ba}$. Among the more evolved rocks there is a wide scatter in the contents of all trace elements. In the classification diagram of Whalen et al. (1987), the granitic rocks plot in the field of fractionated I-type granite and into the A-type field (Figure 11).

\section{Muaquia Complex}

The Muaquia Complex occurs southwest of Mavago, centered on $37^{\circ} \mathrm{E} 13^{\circ} \mathrm{S}$ (Figure 1). It structurally overlies the Marrupa Complex and is interpreted as a Pan-African nappe (Viola et al., 2008). In the western part of the complex, aeromagnetic data show conspicuously low relief, in contrast to most of the surrounding lithological units, which show contrasting high and low banded anomalies, parallel with the observed banding and lineaments on satellite images.

The Muaquia Complex (Table 7) mainly comprises part of a heterogeneous supracrustal sequence attributed to the Chiure Supergroup by Pinna et al. (1993). The term "Muaquia Group" was used by Costa et al. (1983) for the basal sequence of metasedimentary and ultramafic igneous rocks in the Mugeba klippe farther south. Exposure is sparse, but some general conclusions can be drawn:

- Compositions are mainly granitic and the textures are mainly mylonitic.

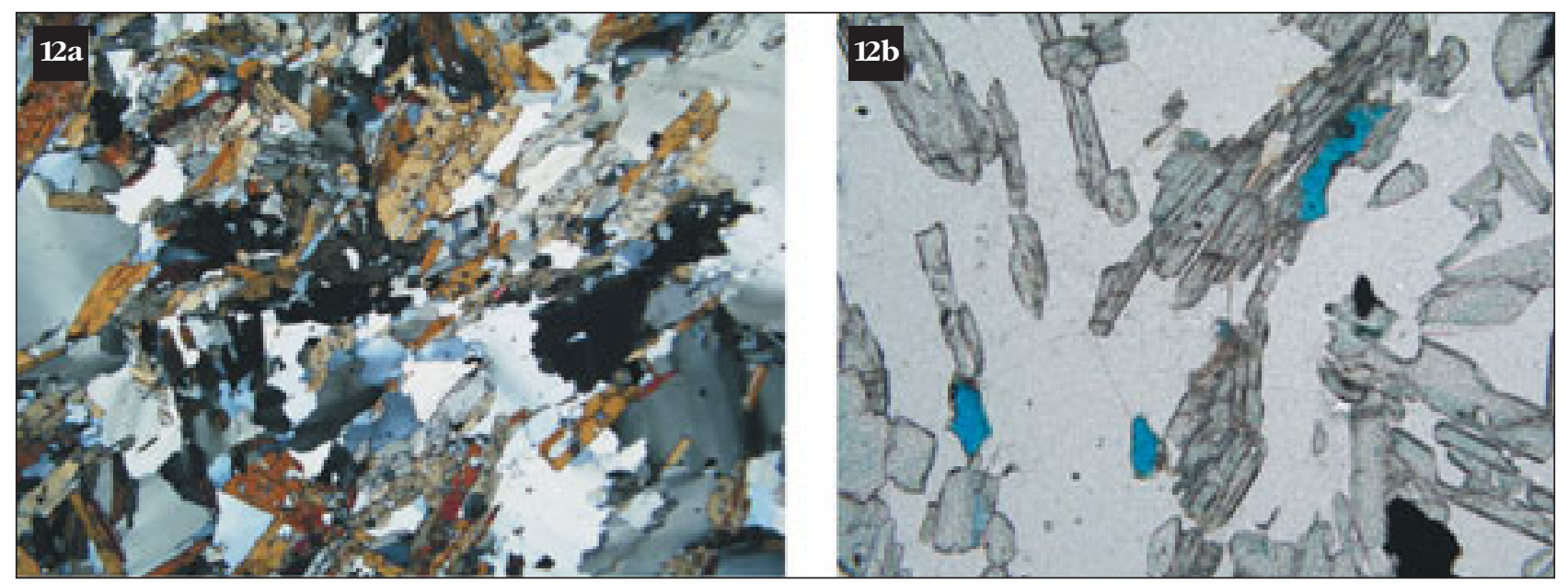

Figure 12. Muscovite-kyanite quartzite in the Muaquia Complex. (a) Randomly orientated kyanite in a groundmass of strained quartz (width of photo 6mm), (b) Kyanite and lazulite (vivid blue) in groundmass of quartz (width of photo $1.5 \mathrm{~mm}$ ) ( UTM 375228840 , 8572186 ). 


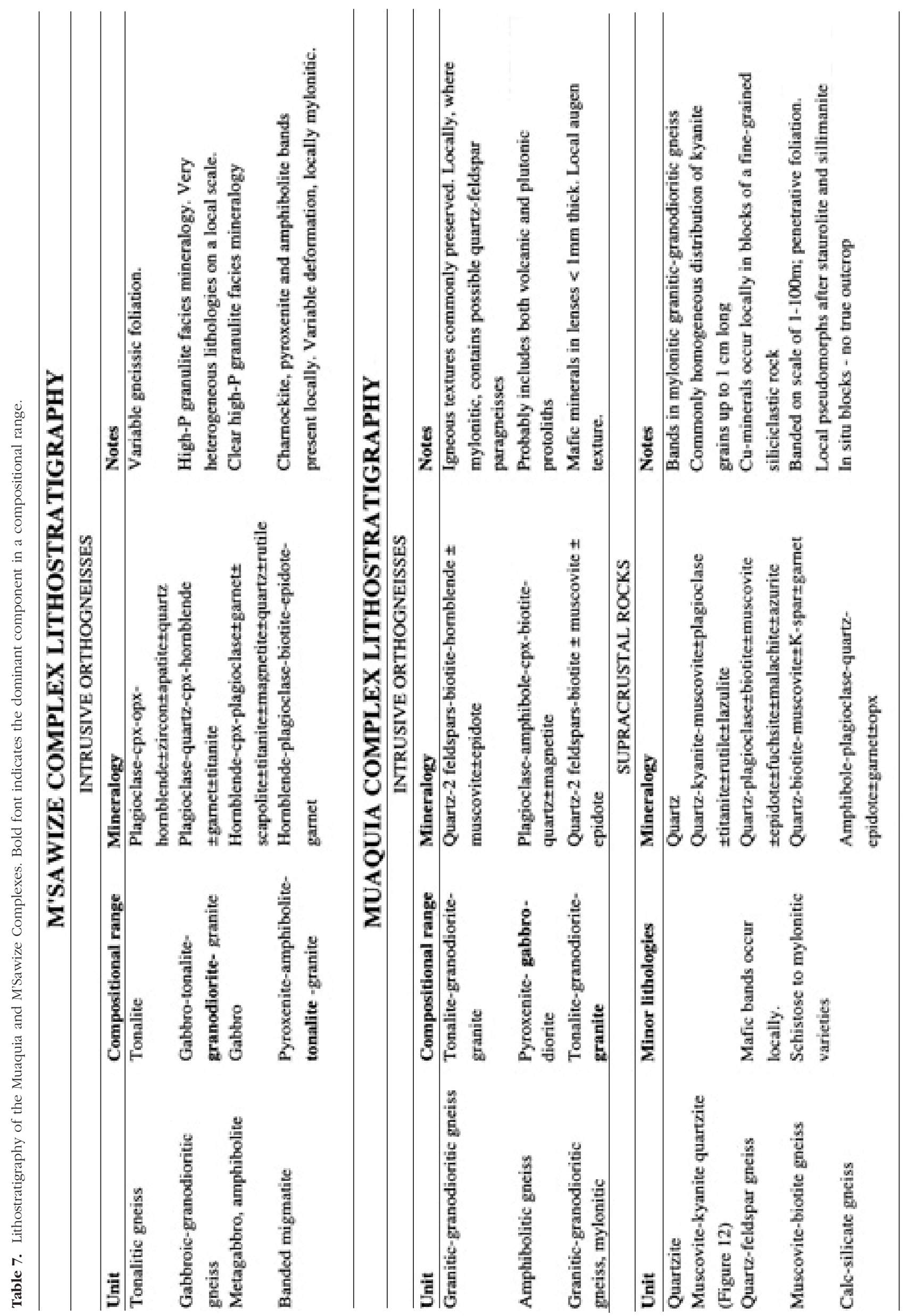


M. OFTEN, J S. SANDSTAD, A SOLUI, E. TVETEN, G. VIOLA, R.M. KEY, R. A. SMITH, E. GONZALEZ, LJ. HOLLICK,

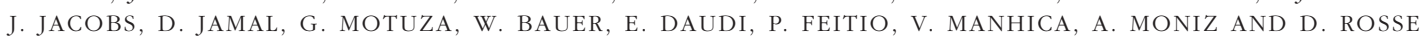

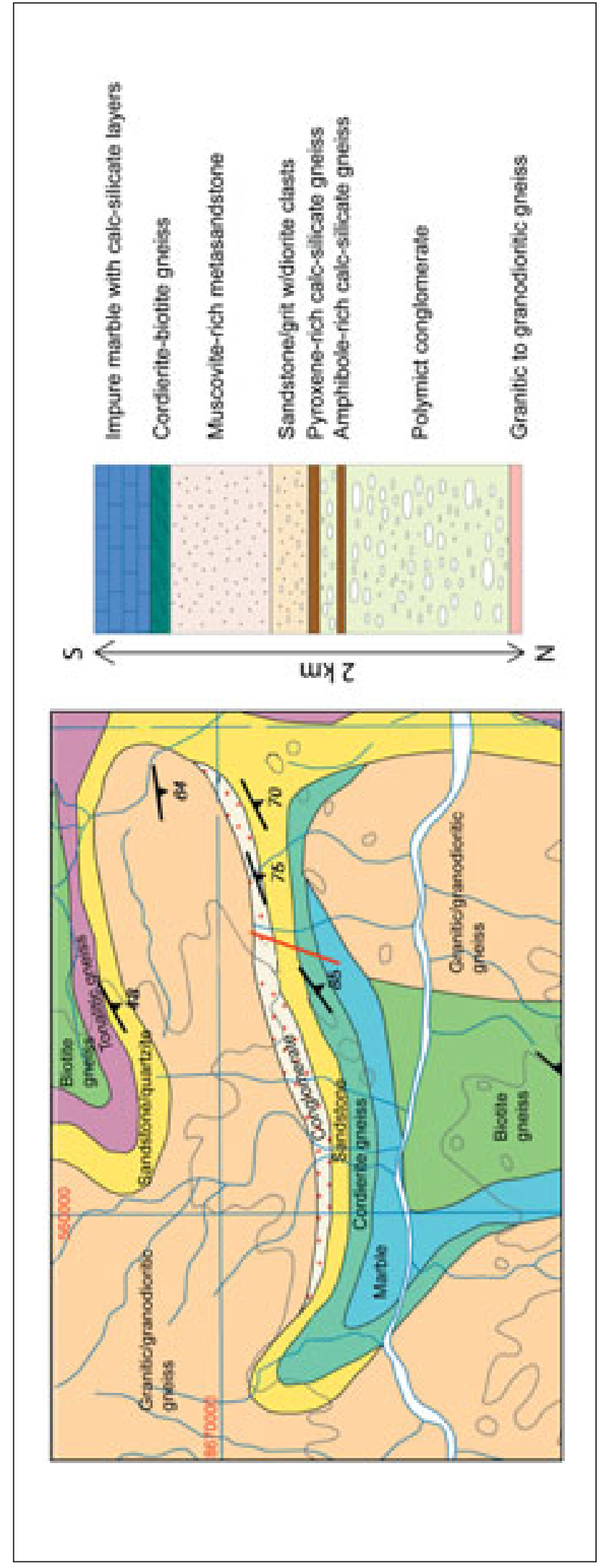

Figure 13. Part of sheet 1239 Meluco, showing the site of a wellexposed sedimentary sequence. The red line is $2 \mathrm{~km}$ long and shows the section sketched to the right. Chemostratigraphic dating (Melezhik et al., 2008) of marbles elsewhere in the Lalamo Complex suggests that the marble in this sequence has an age of $740 \mathrm{Ma}$.
- Small lenses of quartzite, kyanite quartzite (Figure 12) and quartz-rich two-mica schists are found, especially in the west. To the east the meta-supracrustal rocks are less fragmented and form larger units of quartzfeldspar paragneiss with infolded amphibolite and calc-silicate rocks.

- More weakly deformed mega-lenses (3 to $4 \mathrm{~km}$ across) of granite, tonalite and granodiorite are preserved within the main lithology near the contact with the Marrupa Complex in the eastern half of the Muaquia Complex.

- Late shear deformation has created shear surfaces and microshears in all lithologies, initiating growth of muscovite, chlorite and/or epidote. Deformation increases towards the contact with the Unango Complex to the west.

- There are a few, widely separated indications of an early high-pressure metamorphism.

\section{M'Sawize Complex}

The M'Sawize Complex, southwest of Mavago, overlies and is almost enclosed within the Muaquia Complex (Figure 1). The two complexes are characterized by strongly contrasting lithologies (Table 7) and textures, so it is necessary to define them as separate complexes. Both complexes have, however, experienced early highgrade metamorphism. The orthopyroxene-free garnetclinopyroxene-plagioclase \pm quartz assemblage found in a foliated metagabbro in the M'Sawize Complex indicates an estimated $\mathrm{P}$ of $11.5 \mathrm{~Kb}$ and $\mathrm{T}$ of $800^{\circ} \mathrm{C}$ (Norconsult 2007a). Late epidote growth is present in both units, which may suggest that they were juxtaposed prior to final retrogression. An early phase of high-pressure granulite-facies metamorphism is recorded in the mafic gneisses of the M'Sawize Complex.

The M'Sawize Complex, as defined here, comprises part of the M'Sawize Group of Pinna et al. (1993), who included the unit in their Lurio Supergroup. The latter corresponds to the "eastern thrust granulite" preserved in synforms as nappe outliers (Pinna et al. 1993). The northern and western contacts of the M'Sawize Complex appear to be related to several shear zones that cross the region from the northeast and which are deflected sharply southwards southeast of Mavago, adjacent to the contact with the Unango Complex to the west. The M'Sawize Complex is interpreted as a nappe, thrust over the Muaquia Complex with an overall top-to the-northwesterly transport direction (Viola et al., 2008). However, detailed kinematic analysis of shear zones associated with the M'Sawize Complex also shows top to the southeast kinematics (Norconsult 2007). These shear zones are folded about northeasterly to southwesterly upright kilometric-scale open folds, which suggests a pre-thrusting/folding phase of extension. In addition, a later regional northwest to southeast extensional phase was also documented by Viola et al. (2008) postdating thrusting and marking the collapse of the overthickened crust. Therefore these shear zones are likely to record 


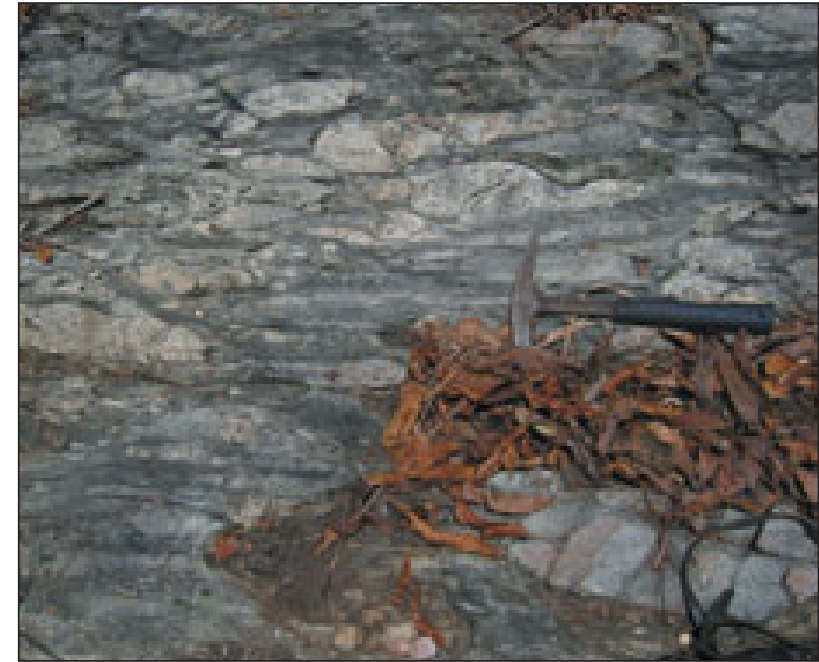

Figure 14. Polymict conglomerate, with flattened fragments mainly of various orthogneisses in a matrix of biotite gneiss (UTM 37S, 565363, 8668830).

evidence of a complex, long-lived structural history with several periods of reactivation.

The M'Sawize Complex is dominated by mafic to felsic, commonly granulite-facies metaigneous rocks (Table 7). The intrusion of these orthogneisses and the "early" granulite-facies metamorphism are undated: they may be Irumide or Pan-African in age. However, U-Pb dating of a minor tonalite pluton in the complex yields an intrusion age of $622 \pm 9 \mathrm{Ma}$ (age reprocessed from $640 \pm 4 \mathrm{Ma}$ in Norconsult 2007a), showing that at least this intrusion is early Pan-African in age.

\section{Lalamo Complex}

The Lalamo Complex comprises part of the former Chiure Supergroup of Pinna et al. (1993). It is situated east and north of the Nairoto Complex. It is overlain by the Rovuma Basin to the east (Figure 1) and is interpreted as overlying the Nairoto and Meluco Complexes. The western contact against the Nairoto Complex is a steep dextral shear zone, along which various units of the Lalamo Complex are truncated. As described above, the contact between the Lalamo and Meluco Complexes is tectonised, probably a thrust (the Chiure Supergroup basal thrust of Pinna et al. 1993).

The Lalamo Complex is predominantly made up of various metasupracrustal rocks generally at amphibolite grade. It is made up mainly of biotite gneiss, metasandstone, quartzite, marble, amphibolite and conglomerate and minor meta-igneous rocks of granitic to ultramafic composition. The biotite gneiss includes graphite-bearing units which are exploited in the Ancuabe area. The timing of deposition of the supracrustal sequences has been estimated using chemostratigraphic methods on two thin marble layers which yielded deposition ages of around $740 \mathrm{Ma}$ (Melezhik et al., 2008). An orthogneiss yielded a U-Pb zircon intrusion age of $696 \pm 13 \mathrm{Ma}$ (Norconsult, 2007a).

South of the village Homba, north of Meluco, a wellexposed section of metasediments illustrates the diversity of lithologies in the Lalamo Complex (Figure 13). The section includes (from north to south) horizons of conglomerate, meta-arenite and quartzite, alumina-rich, cordierite-bearing biotite gneiss and impure marble. The sequence is $\sim 2 \mathrm{~km}$ thick and dips 70 to $80^{\circ}$ south-southeast. The conglomerate is strongly

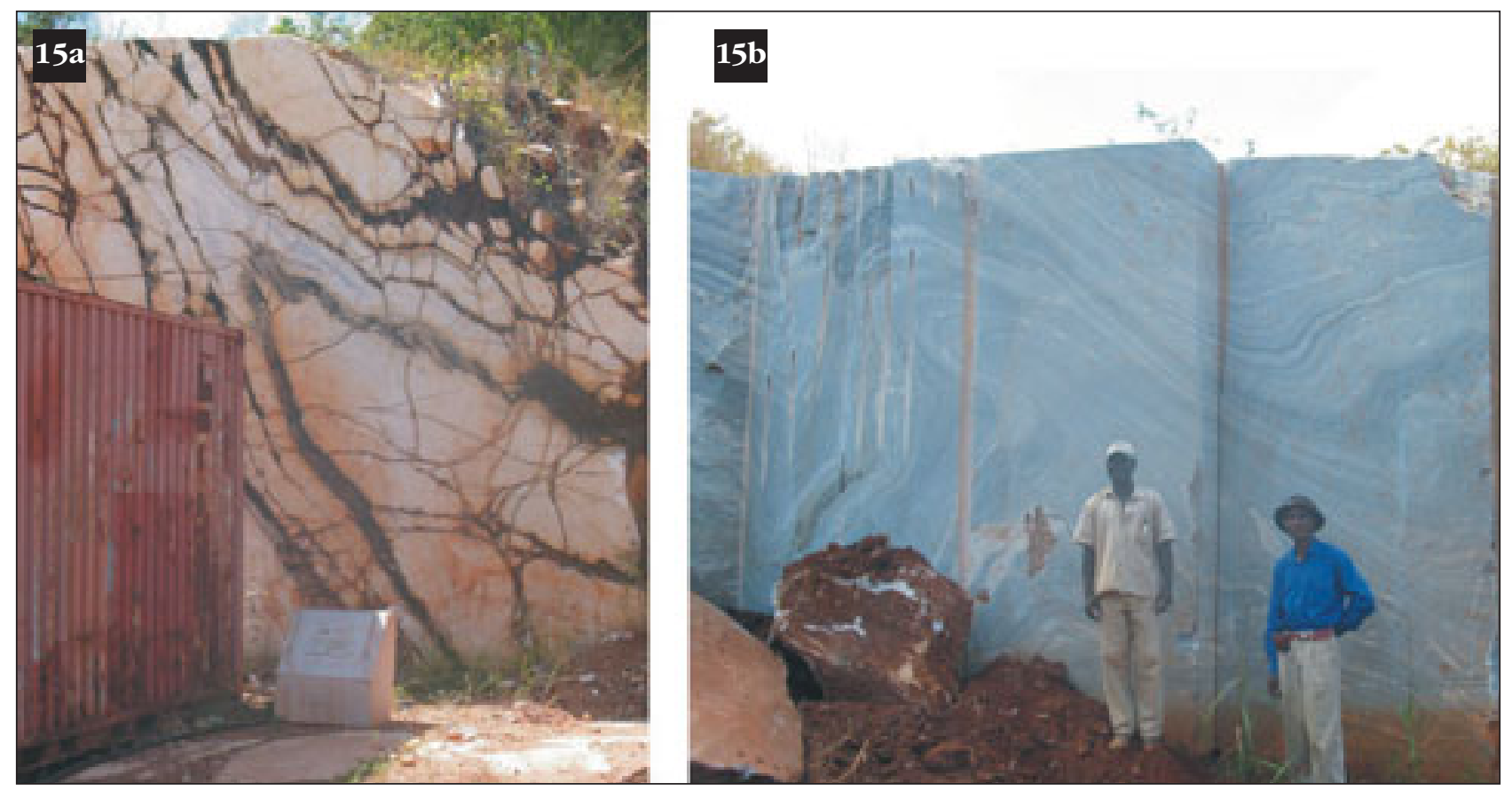

Figure 15. The Montepuez marble quarries, showing tight folding and foliation-parallel bedding in the marble. 


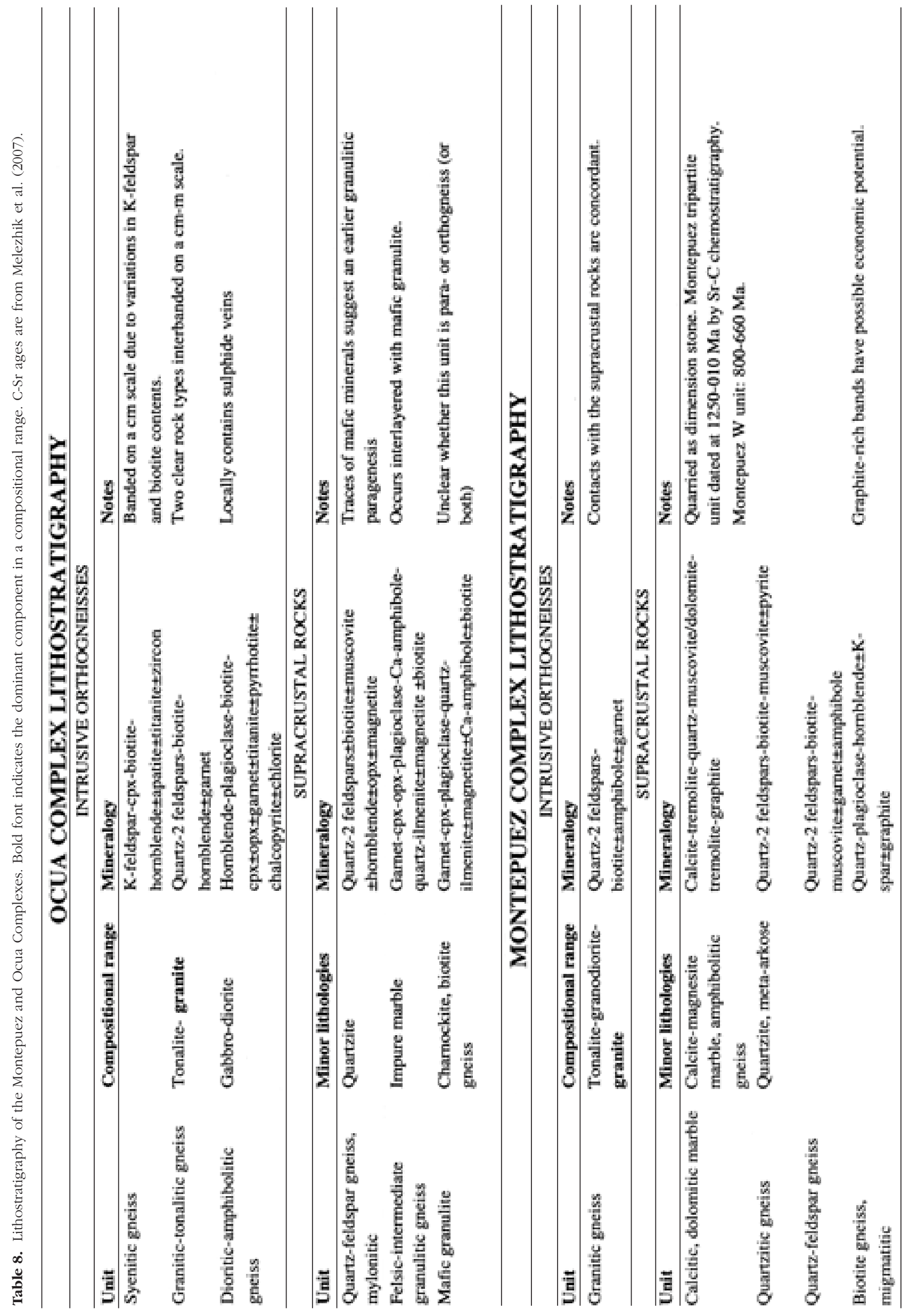




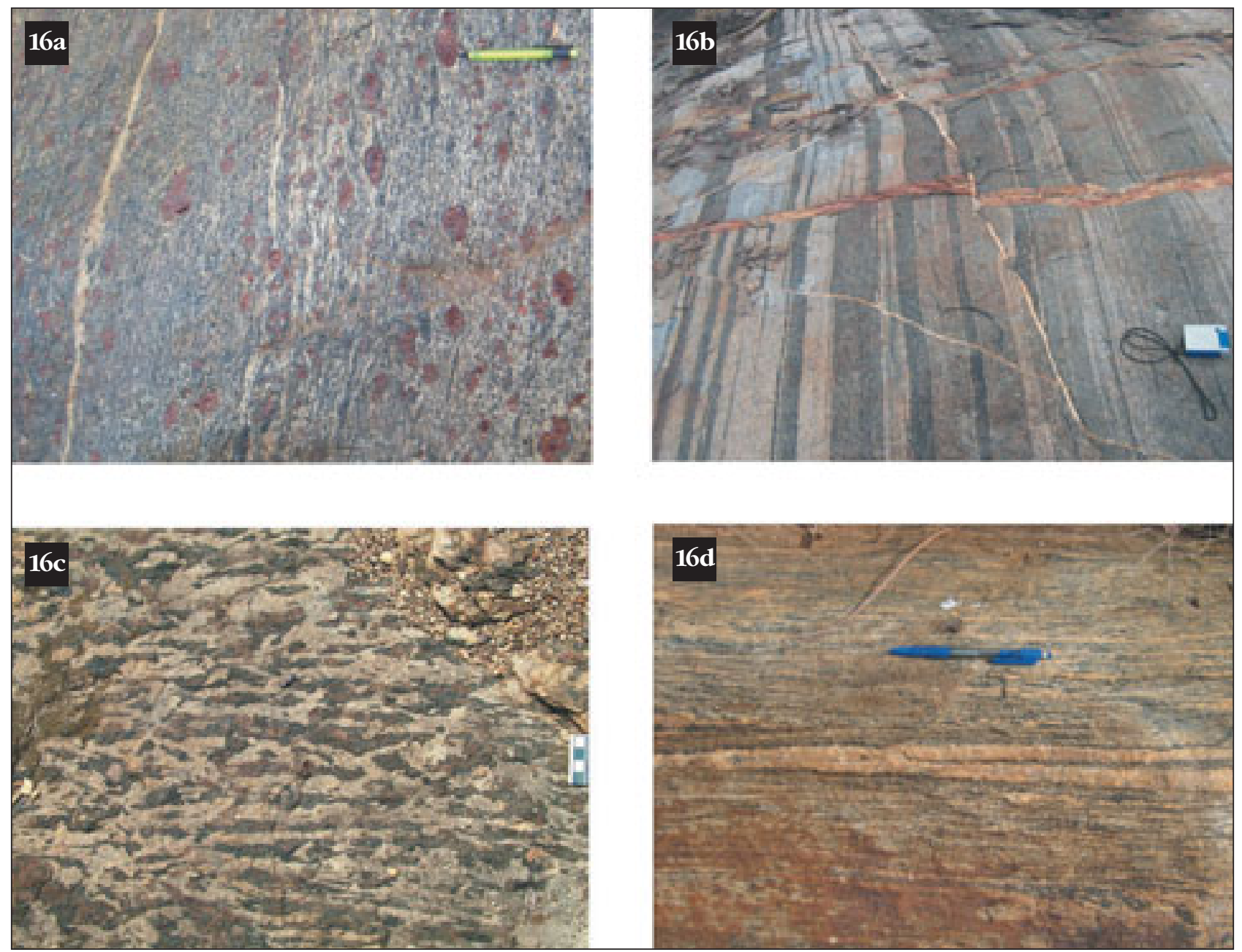

Figure 16. Ocua Complex lithologies: (a) Mafic granulite with cm scale garnet phenoblasts (UTM 375, 608709, 8506268); (b) Well-defined compositional banding in felsic (light grey) to intermediate granulites (dark grey) in the Ocua Complex. Note the early set of leucocratic veins (left to right) occupying ductile shear zones in the granulites, while a younger set of veins occupies faults with late, brittle displacements (UTM 375 260356, 8304548); (c) Coarse-grained charnockitic gneiss of the Ocua Complex. Note the strong foliation, mainly defined by coarse aggregates of elongate amphibole (black) and bypersthene (brown) with grey feldspar (UTM 37S 332641, 8391627); (d) Mylonitised granitic gneiss. The rock is pervasively injected by migmatitic leucosomes that are themselves sheared into the progressively developing foliation. (UTM 37S, 588132, 8492276).

foliated and sheared. It contains up to 20 to $30 \mathrm{~cm}$ large, sub-rounded clasts of fine-grained granite, diorite, quartz-feldspar gneiss, amphibolite and calc-silicate gneiss in a matrix of fine-grained biotite gneiss, which also seems to be clastic (Figure 14). To the south, across strike, there is fine-grained, strongly deformed amphibolitic gneiss, which probably represents metamorphosed calcareous sediment. This is structurally overlain by another layer of the conglomerate, followed by a fine-grained homogeneous layer of amphibolepyroxene gneiss. Thin sections of this rock show it to be heteroblastic, with up to $5 \mathrm{~mm}$ strongly poikiloblastic grains of clinopyroxene (probably diopside) overgrowing a matrix of $0.1-1 \mathrm{~mm}$ grains, predominantly of quartz, clinoamphibole, K-feldspar and carbonate. This rock is also most likely a calcareous metasediment.

Structurally above the amphibole-pyroxene gneiss there is a thick unit of muscovite-biotite schist/gneiss, which represents a meta-arenitic sandstone, quite strongly sheared with some $\mathrm{mm}-\mathrm{cm}$ sized clasts of quartz clasts and of dioritic gneiss. This arenitic sandstone grades into a more fine-grained sandstone, now a biotite-muscovite schist/gneiss, which is muscovite-rich. It contains up to 2 to $3 \mathrm{~mm}$ quartz grains and is otherwise bedded to banded on a scale of a few $\mathrm{dm}$. Above this metasandstone, about $1 \mathrm{~km}$ to the southwest, there is a dark argillaceous metasediment consisting of up to 25 to $30 \mathrm{~cm}$ long cordierite crystals in a "garben" texture with abundant $\mathrm{cm}$-sized red garnet and biotite. The poikiloblastic grains of cordierite locally contain relict staurolite. Important accessories include chlorite, muscovite and gedrite.

This rock probably represents an aluminous meta sediment, and forms the top of a well-defined transgressive sequence that starts with the conglomerate at the structural base, grading into arenitic sandstone, 
M. OFTEN, J.S. SANDSTAD, A SOLLI, E TVETEN, G VIOLA, R.M KEY, R. A SMITH, E. GONZALEZ, L.J. HOLLICK,

J. Jacobs, D. JAmal, G. motuza, W. BAuer, E. DAudi, P. Feitio, V. manhica, A. Moniz And D. Rosse

homogeneous finer-grained sandstone and then passes up to argillaceous metasediment at the structural top. This sequence is unusual in itself and in its level of exposure within the project area. Further up section (structurally), there is an impure, strongly sheared marble sequence about $100 \mathrm{~m}$ thick, with interbedded calc-silicate gneiss. The marble contains fine-grained graphite and locally epidote and diopside. There are also individual calc-silicate layers up to $1 \mathrm{~m}$ thick.Between the cordierite gneiss and marble there are outcrops of pegmatite with abundant black tourmaline. The marble is probably coeval with other marble units in the Lalamo Complex and in the southern part of the Xixano Complex dated at ca. $740 \mathrm{Ma}$ (Melezhik et al., 2008).

\section{Montepuez Complex}

The Montepuez Complex forms a wedge-shaped unit of strongly deformed para- and orthogneiss on the northern flank of the Lurio Belt (Figure 1). It includes part of the Montepuez and Chiure (s.s.) Groups of Pinna et al. (1993), defined as part of the their Chiure Supergroup. The Montepuez Complex is lithologically similar to the adjoining Lalamo and Xixano Complexes, though the Montepuez and Lalamo Complexes are everywhere separated by a felsic gneiss unit attributed to the Nairoto Complex. The Montepuez Complex comprises orthogneisses ranging from granitic to amphibolitic in composition, and paragneisses comprising mainly quartzite, meta-arkose, marble, quartz-feldspar gneiss and biotite gneiss (Table 8). The rocks are strongly folded into tight and isoclinal folds on all scales, and have later been cut by a number of mainly norttheasterly to southwesterly trending shear zones. The strong deformation makes the lithological succession very complex, with large variations on all scales both within and between the lithologies. The mineral parageneses present (hornblende -plagioclase -quartz \pm garnet) suggest that the complex has generally undergone amphibolite-grade metamorphism. Chemostratigraphic methods, using ${ }^{87} \mathrm{Sr} /{ }^{86} \mathrm{Sr}$ ratios (Melezhik et al., 2007), have yielded an age between 1.1 and $1.05 \mathrm{Ga}$ for the "tripartite" marble unit which is exposed in the quarries near Montepuez (Figure 15), which produce blocks for export and for national consumption.

\section{Ocua Complex}

The term "Ocua Complex" was introduced by Norconsult (2007a) to clarify existing confusion around the term "Lurio". The term Lurio has been used in a lithostratigraphic sense (e.g. Lurio "Group" and "Supergroup" of Pinna et al., 1993), and as a structural entity (e.g. the Lurio Belt of Pinna et al., 1993; Kröner et al., 1997; Sacchi et al., 2000). The newly defined Ocua Complex includes the lithologies in the core of the Lurio Belt, previously considered as the type lithologies of the Lurio Group, by Pinna et al. (1993). It is mainly made up of highly deformed gneisses, commonly mylonitic. Typically, the lithologies are granulites and include orthogneisses, commonly mafic, and metasupracrustal rocks (Table 8, Figure 16).

The high-strain character of the eastern Lurio Belt fades progressively to the southwest, where it becomes infolded within the Marrupa Complex and, to a lesser extent, the Nampula Complex Viola et al., 2008). Consequently, in the east, the Ocua Complex forms a continuous, ca. $20 \mathrm{~km}$ wide unit, while to the west, closer to the border with Malawi, the complex comprises a series of belt-like bodies, layers and lenses on all scales, which are concentrated along the wide northeasterly to southwesterly trending tectonic zone that separates the Nampula and Unango Complexes.

Due to its structural complexity, therefore, the Ocua Complex is probably a composite unit, containing slices of diverse rock units, deformed, transposed and dismembered during Pan-African tectonic events, and not originally a single lithostratigraphic unit. The complex can thus be regarded as a tectonic mélange including granulites, sheared and transposed high-grade gneisses and metasediments. The traditional separation into paragneisses and orthogneisses cannot be confidently made for large parts of the complex. A detailed study of the metamorphic development of the Ocua Complex by Engvik et al. (2007) documented peak metamorphic conditions of up to $1.57 \pm 0.14 \mathrm{GPa}$ and $949 \pm 92^{\circ} \mathrm{C}$, corresponding to crustal depths of c. $55 \mathrm{~km}$, at $557 \pm 16 \mathrm{Ma}$.

\section{Neoproterozoic metasedimentary rocks}

Overlying the Mesoproterozoic complexes, two sequences of low-grade Neoproterozoic metasedimentary rocks have been recognised in northeatern Mozambique, north of the Lurio Belt. These were termed the Cobué and Geci Groups by Pinna et al. (1993), but the former has been renamed the Txitonga Group after a prominent mountain peak centrally located in the group; the town of Cobué is located outside the group (Figure 1).

\section{Txitonga Group}

The Txitonga Group overlies and is bounded by the Palaeoproterozoic Ponta Messuli Complex in the west and is covered by Karoo Supergroup rocks of the Maniamba graben to the east. It is dominated by metasedimentary rocks, mainly metagreywacke, metasandstone and quartz-mica schist and chlorite-rich schist. In the northern part of the unit there are numerous bodies of metagabbroic rock, greenstone and greenschist and minor felsic metavolcanic rocks. One (meta) rhyolite yields a crystallization age of $714 \pm 17 \mathrm{Ma}$ (Bjerkgård et al., 2009), demonstrating a Neoproterozoic age for the group. There is no indication that the metamorphic grade ever exceeded greenschist facies in this area, though close to Cobué, garnet and staurolite are found, indicating higher (amphibolite) metamorphic grade in the east. Pinna et al. (1993) reported the same metamorphic distribution, with sillimanite in the Cobue area. A late retrogressive event has, however, affected 
the Txitonga lithologies, leading to regional sericitisation and local carbonatisation, so that the pattern of the earlier metamorphic event is difficult to document.

Primary native gold occurs in quartz veins in lowgrade metasedimentary rocks associated with mafic dykes and sills in the Txitonga Group. Artisanal gold mining has taken place in the Txitonga Group since 1990 (Bjerkgård et al., 2009), with both alluvial and primary gold in quartz veins exploited.

\section{Geci Group}

The Geci Group occurs as four northeasterly to southwesterly trending lenses tectonically emplaced within Unango Complex rocks, southeast of Metangula (Figure 1). The group includes low-grade metamorphosed volcanic rocks, clastic carbonates, mudstones, sandstones, conglomerates and rocks with possible glacial affinities. The two most closely studied lenses consist of low-grade metamorphosed carbonate rocks with subordinate chlorite-muscovite schist and conglomerate. Although contacts between the Geci rocks and the granulite complexes are not exposed, the sharp discordance in metamorphic grade indicates that the contacts are tectonic. In places, primary depositional features are well preserved (Melezhik et al., 2006). The dominant rocks are calcarenites, dolarenites, calcite matrix-supported and dolostone clast-supported carbonate breccias forming beds with erosional bases, normal and reverse graded bedding, and welldeveloped Bouma sequences. Dolomicritic, microbial and oolitic dolostone clasts were apparently derived from the margin of a shallow-water carbonate platform and redeposited by turbidity currents on a continental slope with calcareous sedimentation. A chemostratigraphic study by Melezhik et al. (2006) showed that the least-altered ${ }^{87} \mathrm{Sr} /{ }^{86} \mathrm{Sr}$ and $\delta^{13} \mathrm{C}$ ratios suggest an apparent depositional age of either 590 to 585 or 630 to $625 \mathrm{Ma}$. This provides a lower age limit for juxtaposition of the low-grade Geci Group rocks and granulite-facies rocks of the Unango Complex.

\section{Pan-African (Cambrian) intrusive rocks}

The Ocua Complexes and the southern parts of the Unango and Marrupa Complexes have been intruded extensively, but not uniformly, by late- to post-tectonic "Pan-African" granites, during and immediately after the Pan-African orogeny, between ca. 550 and $490 \mathrm{Ma}$ (Jacobs et al., 2008; Bingen et al., 2009). In this region, two suites are known as the Malema and Niassa Suites. A further suite, the more voluminous Murrupula Suite, intrudes the Nampula Complex, south of the Lurio Belt. The Malema and Niassa Suites do not correspond to the alkaline/carbonatite intrusives, which were included in the overview by Woolley (2001) and which formed part of the basis for the proposal that such complexes indicate the location of Proterozoic sutures (Burke et al., 2003). Alkaline intrusives found in the Unango Complex (Lulin, 1984; Bingen et al., 2009) are Neoproterozoic in age.

\section{Malema Suite}

A number of sub-circular to ellipsoidal granitoid ring complexes occur along a north-northeasterly oriented line parallel to, and within the Lurio Belt, where they intrude rocks of the Marrupa and Ocua Complexes. They appear to be particularly associated with the western extension of the Lurio Belt, west of the zone of most intense flattening, in a tectonic regime where the flattening strain has given way to folding and splayed shear zones. A number of smaller plutons and irregularly shaped bodies of granite that have an identical geophysical signature and topographic expression similar to the ring complexes are included in the suite. Three of the plutons are compositionally zoned, the Serra Romulo, Serra Nampatua and Lalaua plutons. Others are sub-circular in plan form, but appear to be composed only of granite (e.g. Serra Mancuni, Monte Sirapi plutons), while others (e.g. Malema pluton) are composed of charnockite. Still others are irregular in shape, such as the Chihulo pluton.

About half of the larger Malema Suite plutons are zoned ring complexes consisting of various compositional phases arranged in a more or less concentric fashion. Some plutons have sub-parallel, curved, external satellite bodies which resemble ring dykes (e.g. the Lalaua pluton). Pluton cores are typically unfoliated, but a weak marginal fabric, parallel to the contacts is often observed. The compositional variations seen include granite (ss), monzogranite, monzonite, syenite and charnockite (the latter typically forming a small, sub-circular core) with rare gabbro. All compositions tend to be equigranular, but porphyritic phases also occur.

\section{Niassa Suite}

The Niassa Suite consists of several granitic to syenitic intrusions that form prominent mountains from Meponda in the $\mathrm{N}$, and continue southeastwards along the border with Malawi along a northwsest to southeast trend. The suite includes four major ring complexes (Mt. Metonia, Mt. Livigire, Mt. Nicucule and Mt. Chande). Except for the latter, which consists of alkali-syenite surrounding a core of alkali-granite, they are all mainly syenitic in composition. Minor phases of concordant medium-grained, leucocratic gneissic granite are also recognised.

The Mt. Metonia syenite, $40 \mathrm{~km}$ south-southwest of Lichinga, is the largest of the syenitic ring dykes. It is made up of medium- to coarse-grained, equigranular homogeneous, pink-weathering quartz-biotite-syenite. Towards the centre of the ring, the pink quartz syenite is coarse-grained with large pink microcline perthite, minor plagioclase and quartz, biotite clots with poikilitic hornblende and magnetite with accessory titanite, apatite and epidote/zoisite

The Mt. Livigire alkali syenite forms a large horseshoe-shaped intrusive complex ca. $80 \mathrm{~km}$ south of Lichinga, comprised of texturally heterogranular, medium- to coarse-grained, locally slightly foliated 


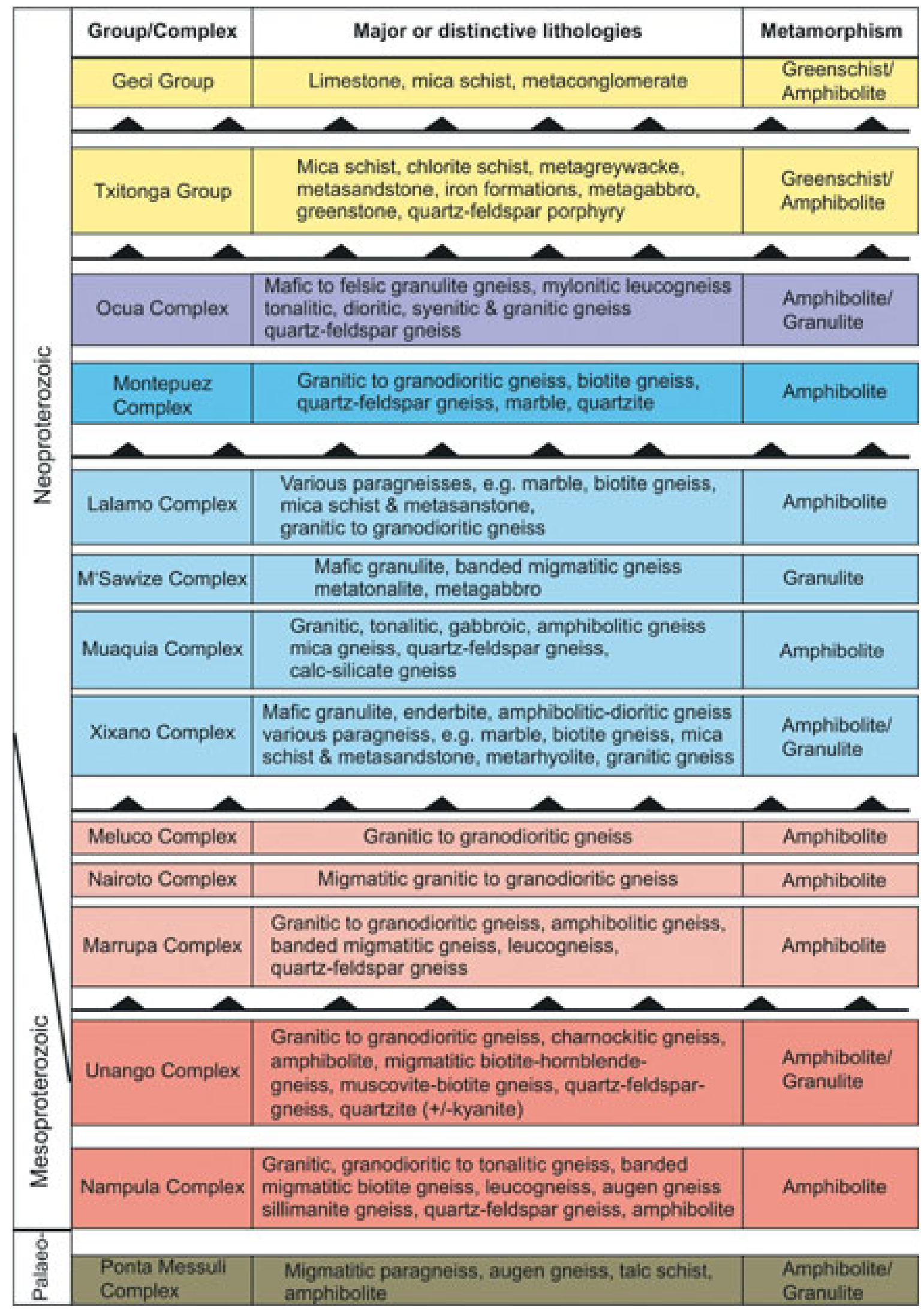

Figure 17. Overview of the main Proterozoic tectonostratigraphic units in northeast Mozambique north of the Lurio Belt. The Nampula complex, south of the Lurio Belt is also shown. The main tectonic boundaries are shown by the saw-tooth lines. 
biotite-bearing alkali-granite to alkali syenite. The Mt. Nicucule intrusion forms a syenitic ring dyke with a diameter of $6.5 \mathrm{~km}$, while the undeformed Mt. Chande alkali-syenite forms a ring structure around the central peak of alkali-granite.

Some members of the suite are granitic. For example the Mt. Lissiete granite is a distinctive intrusion forming the prominent mountain of Lissiete together with a number of large koppies to the east and north. The coarse-grained granite is homogeneous, unfoliated and composed of white to pale-pink feldspar, quartz, amphibole and abundant books of biotite reaching more than a centimetre in size. Some K-feldspar is evident.

\section{Discussion}

\section{Lithostratigraphy and tectonostratigraphy}

The ambition of this publication is to establish the lithostratigraphic/tectonostratigraphic framework adopted in the new map of northestern Mozambique (Norconsult, 2007a; b). Hereafter, this framework, as summarized in Figure 17, is compared with the one of Pinna et al. (1993). The seminal work of Pinna et al. (1993) followed the first 1:1000 000 scale geological map of the country (Pinna and Marteau, 1987), in which the major tectonostratigraphic units then recognized, were defined and delimited.

According to Pinna and Marteau (1987) the same fundamental Mesoproterozoic ("Mozambiquan") crustal blocks were continuous north and south of the Lurio Belt. With a revised and complex nomenclature, Pinna et al. (1993) subdivided the area into six broad tectonostratigraphic units (in bold), listed here with our approximate equivalent units (in italics). The Lurio Belt is considered to be a major terrane boundary separating the Nampula Complex to the south, with its distinctive and different lithostratigraphic package, from those to the north (e.g. Viola et al., 2008). High-convergence in the Lurio Belt resulted in formation of a tectonic mélange and in high-pressure granulite-facies metamorphism at $557 \pm 16 \mathrm{Ma}$ (Engvik et al. 2007; Viola et al., 2008). Hence, no pre-Lurio Belt units cross the belt.

- In the northwest, "Unango Group" granulites, corresponding to our (Palaeoproterozoic) Ponta Messuli Complex. However, Pinna et al (1993, p. 38) also point out that alternative interpretations have also been made for this unit, including "an extension of the Ubendian terrane of northern Malawi";

- Southeast of the above, a narrow belt of Neoproterozoic metasedimentary "Katangan" rocks of the Geci and Cobué Groups which we also recognize, as the Geci and Txitonga Groups respectively;

- To the southeast and along most of the border with Malawi, a series of granulite nappes referred to as the "Unango Group" of the "Axial Granulite Complex", including the-Lichinga Unit, Cuamba Unit and Meponda Unit" (Pinna et al., 1993, Figure 3 and Table 1), which together roughly correspond to our Unango Complex.
These rocks were translated eastwards over the central and eastern parts of the region comprised of a broadly antiformal structure which contained a deformed sequence of Mesoproterozoic rocks comprising, in the model of Pinna et al. (1993), from bottom to top:

- Autochthonous migmatites of the "Nampula Supergroup" (Partly our Nampula Complex, south of the Lurio Belt and not the subject of this paper) in which the Marrupa Group approximately corresponds to our Marrupa Complex, the Nairoto Group to part of our Nairoto Complex and the Meluco Group, which includes our Meluco Complex, but is much more extensive (Pinna et al, 1993, Figure 12 and Table 11). We do not recognize Nampula Complex rocks north of the Lurio Belt;

- Autochthonous supracrustal rocks, including mylonites. We do not recognize this unit as such it corresponds to various autochthonous units in the Mesoproterozoic Marrupa Complex and allochthonous Neoproterozoic rocks of the Lalamo, Xixano, M'Sawize and Montepuez Complexes;

- Rocks of the Chiure and Metangula Supergroups. Again these rocks do not correspond to any single units in our model, and occupy areas we interpret as forming units of the Neoproterozoic nappe complexes.

From the above it is clear that the differences in regional distribution and tectonostratigraphic classification between Pinna et al. (1993) and our work are considerable: the contrast is further complicated by differences in application of lithostratigraphic terms (see above).

\section{Geochemical signatures and geological evolution}

Using Rb-Sr isotope data in conjunction with their tectonostratigraphic model, Pinna et al. (1993) proposed a regional geological model involving the following sequence of events:

- 1100 to 850 Ma: Massive plutonic activity, limited deposition of supracrustal successions, granulitefacies metamorphism, orthogneiss emplacement and nappe tectonics during the "Mozambican orogeny". The Mesoproterozoic crustal blocks were considered to be continuous across the Lurio Belt;

- 900 to 538 Ma: Deposition of sediments (some units with a possible glacial affinity), correlated with the Katangan Supergroup of Zambia;

- ca. $550 \mathrm{Ma}$ : Pan-African retrograde metamorphism and tectonics (including some thrusting) in an intracontinental environment.

The new mapping (Norconsult, 2007a, b), supported by geochemical data (Appendix), chemostratigraphic data (Melezhik et al., 2006; 2008) and some $60 \mathrm{U}-\mathrm{Pb}$ zircon or monazite age determinations (Kröner et al., 1997; Engvik et al., 2007; Jacobs et al., 2008; Viola et al., 2008; Bjerkgård et al., 2009; Bingen et al., 2009) leads to an improved, and quite different regional interpretation. 
Palaeoproterozoic high grade felsic rocks, exposed in the northwestern corner of the country in the Ponta Messuli Complex, show a Archaean Sm/Nd depleted mantle model age and record a granulite-facies event dated at $1950 \pm 15 \mathrm{Ma}$ (Bingen et al., 2009). They are interpreted as forming a part of the northwestern foreland to the East African Orogen. This cratonic foreland extends westwards into Malawi and northwards into Tanzania and can be considered as the southeastern termination of the Ubendian and Usagaran Belts attached to the Congo-Tanzania Craton.

Four late-Mesoproterozoic to early-Neoproterozoic crustal blocks, the Unango, Marrupa, Nairoto and Meluco Complexes, form the greater part of the lower tectonostratigraphic level (Mesoproterozoic "basement") of the Mozambique Belt north of the Lurio Belt (Figures 1, 17; Viola et al., 2008). These complexes comprise mainly orthogneisses but also with significant sequences of supracrustal gneisses. The orthogneisses are largely intermediate to felsic in composition, metaluminous, medium- to high-K, alkali-calcic to shoshonitic. They intruded during a comparatively short time span, extending from ca. 1.06 to $0.95 \mathrm{Ga}$ in the Unango Complex, ca. 1.03 to $0.95 \mathrm{Ga}$ in the Marrupa Complex and ca. $0.95 \mathrm{Ga}$ in the Meluco Complex. The most probable geotectonic setting for such extremely voluminous magmatism with the compositions seen is in a volcanic arc. Most of the high$\mathrm{K}$ granitic to charnockitic rocks probably represents a significant degree of recycling of previously formed crust. Plutonic rocks of this type are commonly emplaced in relatively mature continental volcanic arcs and as large, post-collisional batholiths following terrane accretion. The presence of Palaeoproterozoic to Archaean detrital zircons in supracrustal rocks and (uncommon) inherited Archean zircons in some weakly peraluminous granitic gneisses is consistent with this interpretation (Bingen et al., 2009). The Unango Complex was affected by a first granulite-facies metamorphic event at $955 \pm 9 \mathrm{Ma}$. This event can be broadly related to the Irumide orogeny in the Irumide Belt of Zambia (De Waele et al, 2006; Bingen et al., 2009), during which volcanic arcs probably accreted at the margin of the Congo-Tanzania Craton. Nevertheless, we find no clear evidence for major nappe tectonics and orogenesis during this stage (Viola et al., 2008). Consequently, the exact nature of this event is a matter of speculation, and could represent the products of a thermal pulse in the crust following voluminous magmatism or orogeny.

Deposition of the Txitonga and Geci Groups took place in the Neoproterozoic on the crystalline basement. The former overlies the Ponta Messuli Complex foreland and is unaffected by Pan-African high-grade metamorphism. The latter was deposited on the Unango Complex close to the foreland and also escaped highgrade metamorphism. The Geci group reflects platform to continental-slope sedimentation between ca. 630 and 585 Ma (Melezhik et al., 2006).
The Xixano, Muaquia, M'Sawize, Lalamo and Montepuez Complexes overlie the Mesoproterozoic basement with tectonic contacts and are interpreted as Pan-African nappes (Figures 1, 17; Viola et al. 2008). The coverage of geochemical data is not very dense for these complexes. Nevertheless, the Xixano Complex displays a very specific geochemical signature and can be used to to extrapolate to the other Neoproterozoic nappe complexes. The large bodies of mafic to intermediate calcic, low-K orthogneisses in the Xixano Complex, dated at around $740 \mathrm{Ma}$ (Bingen et al., 2009), and characterized by a weak radiometric signature on airborne geophysical surveys (Viola et al., 2008), are characteristic of primitive volcanic arcs. The evolved rocks appear to have a bimodal distribution including low-K tonalite and high-K granite. The mafic to intermediate rocks display granulite-facies assemblages and are interpreted as the lower part of a volcanic arc, either oceanic or pericontinental. The bulk of the magmatic activity in the Xixano, Lalamo and Montepuez Complexes is bracketed between ca. 820 and $700 \mathrm{Ma}$ and consequently these complexes are interpreted as part of one arc or an assembly of arcs developed "outboard" of the Mesoproterozoic continent (Viola et al. 2008). In this context, the metasedimentary sequences they contain can be interpreted as having formed in fore-arc and/or back-arc basins. The occurrence of a continental "basement" older than ca. $820 \mathrm{Ma}$ in the Xixano, Muaquia, M'Sawize, Lalamo and Montepuez Complexes is controversial. Possible evidence includes the ca. 1.1 to $1.05 \mathrm{Ga}$ Montepuez marbles (Melezhik et al., 2008). Establishing the presence of a "basement" in these complexes is nevertheless a key element to reconstruct their paleogeography (oceanic vs. pericontinental arc complexes), and is a task for future research. The evolutionary reconstruction of ancient polyphase orogenic belts is a common problem. In the northernmost part of the East African Orogeny, for example, Șengör and Natal'in (1996) regarded the Arabian-Nubian shield as an example of Neoproterozoic "Turkic-type" orogeny, the key features of which are the formation of very large subduction-accretion complexes (fore-arc basins) into which magmatic arcs migrate, and produce net crustal growth. The assembly of the Xixano, Muaquia, M'Sawize, Lalamo and Montepuez Complexes has the characteristics of such an orogeny. The lateNeoproterozoic (Pan-African) compressional tectonic event was responsible for the final juxtaposition of all the crustal blocks including a major phase of nappe tectonics, leading to crustal stacking, deep burial and granulite-facies metamorphism at about $550 \mathrm{Ma}$ (Engvik et al., 2007; Viola et al., 2008). The Neoproterozoic microcontinents formed "outboard" of the Mesoproterozoic continent were transported as nappes northwestwards onto the Mesoproterozoic crust (Viola et al. 2008). High-convergence in the Lurio Belt resulted in formation of a tectonic mélange under high-pressure granulite-facies metamorphic conditions at $557 \pm 16 \mathrm{Ma}$ (Engvik et al., 2007; Viola et al., 2008). 
Limited Pan African granites and syenites were emplaced in the period between 550 and $490 \mathrm{Ma}$, mainly as late- to post-tectonic ring complexes, with plutons following regional tectonic lineaments (e.g the Malema Suite plutons parallel the Lurio Belt).

\section{Conclusion}

New geological mapping and geochemical characterization of the main rock units in northeast Mozambique, north of the Lurio Belt, (Norconsult, $2007 \mathrm{a}$; b) lead to a division of the crust into three fundamental tectonostratigraphic levels.

1. The Palaeoproterozoic Ponta Messuli Complex is regarded as part of the Ubendian-Usagaran foreland of the East African Orogen.

2. The Mesoproterozoic Unango, Marrupa, Nairoto and Meluco Complexes represent juvenile alkali-calcic to shoshonitic felsic crust that evolved between ca. 1.06 and $0.95 \mathrm{Ga}$. This crust probably formed in a continental-arc setting and was assembled at the southeastern margin of the Congo-Tanzania craton during the Irumidian orogeny.

3. The Xixano, Muaquia, M'Sawize, Lalamo and Montepuez Complexes are juvenile Neoproterozoic complexes, which overlie the Mesoproterozoic crust, which acted as their basement. Mafic to intermediate calcic, low-K, magmatic rocks in these complexes are characteristic of a primitive volcanic arc setting and suggest they developed as volcanic arcs "outboard" of the Mesoproterozoic continent. It is unclear if the four Mesoproterozoic complexes were juxtaposed before this and acted as a single crustal entity. These three tectonostratigraphic levels were juxtaposed into their present-day relative position during the Pan-African orogeny, peaking at around $550 \mathrm{Ma}$.

\section{Acknowledgements}

This work has been carried out as part of the Mineral Resources Management Capacity Building Project, Ministry of Mineral Resources of Mozambique, funded by the Nordic Development Fund and the World Bank, and implemented by a team mainly from the Geological Survey of Norway, the British Geological Survey and the National Directorate of Geology of Mozambique. The authors would like to dedicate the paper to the memory of the late Dr. Eric Hammerbeck, whose ever courteous encouragement played a major role in this project. We would also like to acknowledge the assistance of numerous individuals working at the offices of the Provincial Governors in Niassa, Cabo Delgado, Nampula and Zambesia Provinces. Finally, we thank Kevin Burke, Alex Kisters, Guido Schreurs and the editors for their helpful comments. The paper is being published with the permission of the National Directorate for Geology, Maputo and the Executive Director, BGS.

\section{References}

Andreoli, M.A.G., 1984. Petrochemistry, tectonic evolution and metasomatic mineralisation of Mozambique Belt granulites from S. Malawi and Tete, Mozambique. Precambrian Research, 25, 161-186.

Aquater, 1983a. Noticia explicativa Fohla Munhamade 16736 D2 (644), Maputo, 99pp.

Aquater, 1983b. Carta dos Indicios nao conhecidos pesquisas e minas (na escala 1: 50 000). Noticia explicativa Fohla Munhamade 1636 D 2 (644), Maputo, 73pp.

Aquater, 1983c. Noticia explicativa Fohla Mocuba 1636 D4 (672), Maputo, $124 \mathrm{pp}$.

Aquater, 1983d. Quadrado 1636 (Munhamade) Blocos 52, Geological Map, scale 1: 50 000. Unpublished map, Maputo.

Aquater, 1983e. Quadrado 1636 (Mocuba) Blocos 52, Geological Map, scale 1: 50 000. Unpublished geological map, Maputo.

Aquater, 1983f. Carta dos Indicios nao conhecidos pesquisas e minas (na escala 1: 50 000). Noticia explicativa Fohla Mocuba 1636 D4 (672), Maputo, 72pp.

Barbarin, B., 1990. Granitoids: main petrogenetic classifications in relation to origin and tectonic setting. Geological Journal 25, 227-238.

Bingen, B., Jacobs, J., Viola, G., Henderson, I.H.C., Skår, O., Boyd, R., Thomas, R.J., Solli, A., Key, R.M. and Daudi, E.X.F., 2009. Geochronology of the Precambrian crust in the Mozambique Belt of NE Mozambique, and implications for Gondwana assembly. Precambrian Research, 170, 231-255.

Bjerkgård, T., Stein, H. J., Bingen, B., Henderson, I. H. C., Sandstad, J. S. and Moniz, A., 2009. The Niassa Gold Belt, northern Mozambique - a segment of a continental-scale Pan-African gold-bearing structure. Journal of African Earth Sciences, 53, 45-58.

Bloomfield, K., 1968. The pre-Karoo geology of Malawi, 5. Geological Survey of Malawi, Memoir, 166pp.

Burke, K., Ashwal, L.F. and Webb, S.J., 2003. New way to map old sutures using deformed alkaline rocks and carbonatites. Geology, 31, 391-394.

Costa, M., Casati, C. and di Bartolomeo, G., 1983. Cartográfia geológica e prospecção mineira e geoquímica nas provincias de Nampula e da Zambésia (área de Alto Ligonha). Rel. AQUATER SPA, ING, Maputo.

Costa, M., Ferrara, G., Sacchi, R. and Tonarini, S., 1992. Rb/Sr dating of the Upper Proterozoic basement of Zambesia, Mozambique. Geologische Rundschau, 81, 487-500.

De Waele, B., Liégeois, J.P., Nemchin, A.A. and Tembo, F., 2006. Isotopic and geochemical evidence of Proterozoic episodic crustal reworking within the Irumide Belt of South-Central Africa, the southern metacratonic boundary of an Archaean Bangweulu Craton. Precambrian Research, $148,225-256$.

Direcção Nacional de Geologia, 2001. Mozambique code of stratigraphic terminology and nomenclature, First edition (preliminary)

Engvik, A.K., Tveten, E., Bingen, B., Viola, G., Erambert, M., Feito, P. and de Azavedo, S., 2007. P-T-t evolution and decompression textures of PanAfrican high-pressure granulites, Lurio Belt, northeastern Mozambique. Journal of Metamorphic Geology, 25, 935-952.

Frost, B.R., Barnes, C.G., Collins, W.J., Arculus, R.J., Ellis, W.J. and Frost, D.J., 2001. A geochemical classification for granitic rocks. Journal of Petrology, 42, 2033-2048.

Grantham, G.H., Macey, P.H., Ingram, B.A., Roberts, M.P., Armstrong, R.A., Hokada, T., Shiraishi, K., Jackson, C., Bisnath, A., and Manhica, V., 2008. Terrane correlation between Antarctica, Mozambique and Sri Lanka; comparison of geochronology, lithology, structure and metamrophism and possible implications for the geology of southern Africa and Antarctica. In: M. Satish-Kumar, Y. Motoyoshi, Y. Osanai, Y. Hiroi and K. Shiraishi, (Editors), Geodynamic evolution of East Antarctica: a key to the East-West Gondwana connection. Geological Society, London, Special Publications 308, 91-119.

Holmes, A., 1951. The sequence of Pre-Cambrian orogenic belts in South and Central Africa. In: K.S. Sandford and F. Blondel (Editors), Proceedings of the 18th International Geological Congress. Association des Services Géologiques Africains, London, pp. 254-269.

Huntings Geology and Geophysics Ltd., 1984. Mineral Inventory Project. Final Report. ING, Maputo.

Jacobs, J., Bingen, B., Thomas, R.J., Bauer, W., Wingate, M. and Feitio, P., 2008. Early Palaeozoic orogenic collapse and voluminous late-tectonic magmatism in Dronning Maud Land and Mozambique: insights into the 


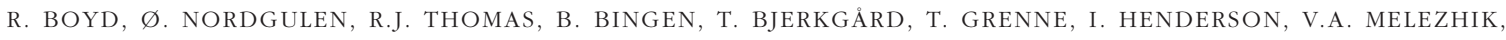

M. OfTEN, J.S. SANDSTAD, A. SOlli, E. TVETEN, G. ViOlA, R.M. KEY, R.A. SMith, E. GONZALEZ, L.J. HOLliCK,

J. Jacobs, D. JAmal, G. motuza, W. Bauer, E. DAudi, P. Feitio, V. manhica, A. MOniz And D. ROsse

partially delaminated orogenic root of the East African-Antarctic Orogen? In: M. Satish-Kumar, Y. Motoyoshi, Y. Osanai, Y. Hiroi and K. Shiraishi (Editors) Geodynamic evolution of East Antarctica: a key to the East-West Gondwana connection. Geological Society, London, Special Publications, 308, 69-90.

Jamal, D., 2005. Crustal evolution in NE Mozambique - implications for Gondwana reconstruction. PhD thesis. University of Cape Town, Cape Town.

Jourde, G. and Wolff, J.P., 1974. Contribuição para o conhecimento da geológia da área de Montepuez (Grau quadrado 1339). BRGM, Orléans, DNG Rel., Maputo, 66pp.

Jourde, G. and Vialette, Y., 1980. La chaîne du Lurio (Nord Mozambique). Un témoin de l'existence de chaînes Kibariennes (800-1350 Ma) en Afrique Orientale, Open File report, BRGM, Orléans, 75pp.

Kröner, A., 2001. The Mozambique belt of East Africa and Madagascar: significance of zircon and $\mathrm{Nd}$ model ages for Rodinia and Gondwana supercontinent formation and dispersal. South African Journal of Geology, 104, 151-166.

Kröner, A., Sacchi, R., Jaeckel, P. and Costa, M., 1997. Kibaran magmatism and Pan-African granulite metamorphism in northern Mozambique: single zircon ages and regional implications. Journal of African Earth Sciences. 25, 467-484.

Kröner, A., Willner, A.P., Hegner, E., Jaeckel, P. and Nemchin, A.A., 2001. Single zircon ages, PT evolution and Nd isotopic systematics of high-grade gneisses in southern Malawi and their bearing on the evolution of the Mozambique belt in southeastern Africa. Precambrian Research, 109, 257-291.

Lächelt, S., 1993. Carta Metalogénica de Moçambique. 1:1.000.000. ING, Maputo.

Lächelt, S., 2004. Geology and mineral resources of Mozambique. Direcção Nacional de Geologia Moçambique, 515pp.

Lächelt, S. and Daudi, E.X.F., 1999. Metallogenic epochs and phases in the Mozambican territory. Journal of African Earth Sciences, 28, 40-41.

Lulin, J.M., 1984. Un nouveau gîte à Nb, Ta, U, REE d'origine magmatique en Afrique orientale: le complexe alcalin tectonisé de Meponda, Précambrian, province de Niassa, Mocambique, PhD thesis, Université d'Orléans, Doc. Bureau de Recherche Géologique et Minère, BRGM 87, Orléans.

Marques, J.M., 2002. Mineral resources potential of Mozambique. unpublished manuscript, Maputo, 34pp.

Marques, J.M., Lächelt, S. and Ferrara, M., 2000. Carta de jazigos e ocorrências minerais, escala 1:1,000,000. DNG, Maputo.

McGregor, V. R. and Friend, C. R. L., 1997. Field recognition of rocks totally retrogressed from granulite facies; an example from Archaean rocks in the Paamiut region, South-West Greenland. Precambrian Research. 86, 59-70.

Meert, J.G., 2003. A synopsis of events related to the assembly of eastern Gondwana. Tectonophysics, 362, 1-40.

Melezhik, V.A., Kuznetsov, A.B., Fallick, A.F., Smith, R.A., Gorokhov, I.M., Jamal, D. and Catuane, F., 2006. Depositional environments and an apparent age of the Geci meta-limestones: constraints on geological history of northern Mozambique. Precambrian Research 148, 19-31.
Melezhik, V.A., Bingen, B., Fallick, A.F., Gorokhov, I.M.,Kuznetsov, A.B., Sandstad, J.S., Solli, A., Bjerkgård, T., Henderson, I., Boyd, R., Jamal, D. and Moniz, A., 2008. Isotope chemostratigraphy of marbles in northeastern Mozambique. apparent depositional ages and regional implications. Precambrian Research 162, 540-558.

Norconsult Consortium, 2007a. Mineral resources management capacity building project, Republic of Mozambique; Component 2: Geological infrastructure development project, Geological Mapping Lot 1; Sheet explanation: 32 sheets; scale: 1:250000, 778pp. + annexes. Credit No. NDF335, Report No. B6.f., National Directorate of Geology, Republic of Mozambique.

Norconsult Consortium, 2007b. Mineral resources management capacity building project, Republic of Mozambique; Component 2: Geological Infrastructure Development Programme, Geophysical Interpretation (Lot1), 146pp., Credit No. NDF335, Report No. B4, National Directorate of Geology, Republic of Mozambique.

Pinna, P., Jourde, G., Calvez, J.Y., Mroz, J.P. and Marques, J.M., 1993. The Mozambique Belt in northern Mozambique; Neoproterozoic (1100-850 Ma) crustal growth and tectogenesis, and superimposed Pan-African (800-550 Ma) tectonism. Precambrian Research, 62, 1-59.

Pinna, P. and Marteau, P., 1987. Carta geologica de Moçambique, 1:1 000000 scale, with explanatory notes. Instituto Naçional de Geologica, Maputo, Maputo.

Sacchi, R., Cadoppi, P. and Costa, M., 2000. Pan-African reactivation of the Lurio segment of the Kibaran Belt system: a reappraisal from recent age determinations in northern Mozambique. Journal of African Earth Sciences, 30, 629-639.

Sacchi, R., Marques, J.M., Costa, M. and Casati, C., 1984. Kibaran events in the southernmost Mozambique belt. Precambrian Research, 25, 141-159.

Saranga de Sousa, I., unpublished manuscripts. Niassa: Notícia Explicativa 1999, 2000, 2001. DNG, Maputo.

\$engör, A.M.C, and Natal'in, B.A., 1996. Turkic-type orogeny and its role in the making of the continental crust. Annual Review of Earth and Planetary Science, 24, 263-337.

Thomas, R.J., Bauer, W., Bingen, B., de Azevedo, S., de Sousa Soares, H., Hollick, L, Feitio, P., Fumo, C, Gonzalez, E., Jacobs, J. Manhica, V., Manuel, S., Motuza, G., Tembe, D., Uachave, B. and Viola, G., 2006. Mozambique belt in the Milange-Mocuba-Malema area, Moçambique. Abstract, 21st Colloquium of African Geology (CAG 21), Maputo, 161-163.

Viola, G., Henderson, I.H.C., Bingen, B., Thomas, R.J., Smethurst, M.A. and De Azavedo, S., 2008. Growth and collapse of a deeply eroded orogen: Insights from structural and geochronological constraints on the PanAfrican evolution of NE Mozambique, Tectonics, 27, TC5009, doi:10.1029/2008TC002284.

Whalen, J.B., Currie, K.L. and Chappell, B.W., 1987. A-type granites: geochemical characteristics, discrimination and petrogenesis. Contributions to Mineralogy and Petrology. 95, 407-419.

Woolley, A.R., 2001. Alkaline rocks and carbonatites of the world. Part 3: Africa. Geological Society of London, London. 372pp.

Editorial handling: L. D. Ashwal 
Appendix. Whole-rock geochemical data, collected by XRF. Major elements in wt $\%$, trace elements in ppm

\begin{tabular}{|c|c|c|c|c|c|c|c|c|c|c|c|c|c|c|c|c|c|c|}
\hline Sample & UTM, E & UTM, $\mathbf{N}$ & Zone & Field name & Tectonic Unit & $\mathrm{SiO}_{2}$ & $\mathrm{TiO}_{2}$ & $\mathrm{Al}_{2} \mathrm{O}_{3}$ & $\mathrm{Fe}_{2} \mathrm{O}_{3}$ & FeOt & MgO & $\mathrm{CaO}$ & $\mathrm{Na}_{2} \mathrm{O}$ & $\mathbf{K}_{2} \mathbf{O}$ & Mno & $\mathrm{P}_{2} \mathrm{O}_{5}$ & Gl.tap & sum \\
\hline 31965 & 690892 & 8573736 & 36 & Biotite-granite & Unango Complex & 71.20 & 0.09 & 16.01 & 1.44 & 1.30 & 0.17 & 0.94 & 4.35 & 4.75 & 0.01 & 0.05 & 0.71 & 99.72 \\
\hline 31341 & 697297 & 8538630 & 36 & enderbite & Unango Complex & 44.67 & 2.58 & 11.70 & 20.59 & 18.53 & 8.46 & 6.85 & 2.34 & 0.83 & 0.29 & 0.32 & -0.28 & 98.35 \\
\hline 31863 & 698895 & 8594032 & 36 & Granitic gneiss & Unango Complex & 78.34 & 0.10 & 11.54 & 1.14 & 1.03 & 0.10 & 0.58 & 3.29 & 3.94 & $<0.01$ & 0.03 & 0.33 & 99.40 \\
\hline 31319 & 699145 & 8534780 & 36 & granitic gneiss & Unango Complex & 60.34 & 0.97 & 17.57 & 6.35 & 5.72 & 0.40 & 2.92 & 4.82 & 5.20 & 0.21 & 0.28 & 0.07 & 99.14 \\
\hline 31862 & 699167 & 8573686 & 36 & Iron ore & Unango Complex & 0.01 & 16.40 & 4.60 & 68.98 & 62.08 & 1.87 & 0.15 & $<0.1$ & 0.02 & 0.26 & 0.02 & -1.13 & 89.09 \\
\hline 31861 & 701475 & 8572098 & 36 & Chlorite amphibole rock & Unango Complex & 45.50 & 3.37 & 14.11 & 14.45 & 13.01 & 6.25 & 8.52 & 2.82 & 0.79 & 0.18 & 0.52 & 1.89 & 98.41 \\
\hline 31335 & 702235 & 8518106 & 36 & porphyritic diorite & Unango Complex & 52.91 & 2.16 & 15.68 & 9.25 & 8.33 & 2.79 & 5.20 & 4.15 & 3.07 & 0.11 & 1.25 & 0.87 & 97.45 \\
\hline 31336 & 702235 & 8518106 & 36 & granitic gneiss & Unango Complex & 73.16 & 0.15 & 14.08 & 1.15 & 1.04 & 0.20 & 1.06 & 3.69 & 5.14 & 0.03 & 0.04 & 0.23 & 98.92 \\
\hline 31334 & 702235 & 8518106 & 36 & amphibolite & Unango Complex & 48.40 & 2.42 & 14.36 & 12.15 & 10.94 & 6.63 & 10.18 & 3.02 & 0.76 & 0.17 & 0.37 & 0.55 & 99.02 \\
\hline 31860 & 703050 & 8572330 & 36 & Granulitic pyroxene gneiss & Unango Complex & 56.00 & 1.68 & 16.14 & 9.89 & 8.90 & 1.28 & 4.01 & 4.48 & 4.49 & 0.24 & 0.42 & 0.20 & 98.82 \\
\hline 31310 & 703060 & 8517170 & 36 & metagabbroic gneiss & Unango Complex & 47.67 & 1.66 & 13.27 & 15.00 & 13.50 & 6.80 & 11.05 & 2.18 & 0.20 & 0.22 & 0.12 & 0.64 & 98.81 \\
\hline 31309 & 703060 & 8517170 & 36 & andesitic dike & Unango Complex & 55.71 & 1.62 & 14.33 & 6.48 & 5.83 & 2.46 & 1.80 & 3.91 & 3.37 & 0.06 & 0.94 & 6.99 & 97.66 \\
\hline 31317 & 704410 & 8531985 & 36 & granitic gneiss & Unango Complex & 63.18 & 0.76 & 15.31 & 6.13 & 5.52 & 2.12 & 4.56 & 3.78 & 2.22 & 0.11 & 0.25 & 0.51 & 98.92 \\
\hline 31311 & 704700 & 8529390 & 36 & granitic gneiss & Unango Complex & 70.28 & 0.56 & 13.80 & 3.36 & 3.02 & 0.55 & 1.60 & 4.46 & 3.81 & 0.08 & 0.13 & 0.16 & 98.78 \\
\hline 31322 & 707600 & 8517530 & 36 & quartz dioritic gneiss & Unango Complex & 63.99 & 0.85 & 15.43 & 5.02 & 4.52 & 2.17 & 4.15 & 3.97 & 2.73 & 0.09 & 0.26 & 0.36 & 99.01 \\
\hline 31823 & 707690 & 8586282 & 36 & Metagabbro & Unango Complex & 46.00 & 3.51 & 13.91 & 15.26 & 13.73 & 5.37 & 8.93 & 2.82 & 1.13 & 0.22 & 0.63 & 0.71 & 98.49 \\
\hline 31321 & 708070 & 8517915 & 36 & Gneiss granite & Unango Complex & 74.91 & 0.25 & 11.13 & 4.61 & 4.15 & 0.02 & 0.57 & 2.16 & 5.39 & 0.04 & 0.04 & 0.18 & 99.29 \\
\hline 31951 & 709534 & 8588644 & 36 & Mafic granulite, gabbroic & Unango Complex & 49.16 & 0.28 & 24.32 & 5.53 & 4.98 & 5.16 & 10.15 & 3.31 & 0.22 & 0.07 & 0.03 & 1.41 & 99.63 \\
\hline 31327 & 711010 & 8521060 & 36 & Mafic dike & Unango Complex & 49.06 & 3.24 & 13.85 & 12.27 & 11.04 & 4.75 & 7.17 & 3.10 & 2.17 & 0.14 & 1.66 & 0.50 & 97.91 \\
\hline 31326 & 711010 & 8521060 & 36 & quartz dioritic gneiss & Unango Complex & 48.49 & 3.22 & 13.49 & 12.16 & 10.94 & 4.74 & 7.09 & 2.92 & 2.47 & 0.16 & 1.76 & 1.45 & 97.94 \\
\hline 31312 & 712835 & 8557540 & 36 & biotite gneiss & Unango Complex & 58.87 & 0.65 & 16.14 & 6.62 & 5.96 & 3.38 & 6.40 & 4.14 & 2.27 & 0.11 & 0.21 & 0.59 & 99.38 \\
\hline 31328 & 713600 & 8530730 & 36 & biotite-hbl gneiss & Unango Complex & 62.47 & 0.91 & 15.48 & 5.32 & 4.79 & 2.34 & 4.42 & 3.99 & 2.50 & 0.09 & 0.29 & 0.40 & 98.21 \\
\hline 31950 & 720830 & 8576368 & 36 & Granitic/monzonitic gneiss & Unango Complex & 64.39 & 0.82 & 15.90 & 5.41 & 4.87 & 0.46 & 0.93 & 4.34 & 6.02 & 0.16 & 0.11 & 0.92 & 99.45 \\
\hline 31339 & 726277 & 8534962 & 36 & qtz-diorite, dark & Unango Complex & 56.01 & 0.97 & 18.56 & 6.89 & 6.20 & 3.45 & 6.43 & 4.88 & 1.47 & 0.12 & 0.31 & 0.04 & 99.14 \\
\hline 31814 & 731245 & 8605294 & 36 & felsic intermediate dyke & Unango Complex & 63.39 & 0.50 & 13.59 & 7.24 & 6.52 & 0.07 & 1.60 & 4.96 & 3.85 & 0.25 & 0.07 & 4.37 & 99.87 \\
\hline 31315 & 733640 & 8541300 & 36 & metagabbroic gneiss & Unango Complex & 51.47 & 0.73 & 16.79 & 9.05 & 8.15 & 8.00 & 9.64 & 2.59 & 0.76 & 0.15 & 0.14 & 0.19 & 99.52 \\
\hline 31330 & 735675 & 8509020 & 36 & biotite-gneiss & Unango Complex & 60.37 & 0.74 & 15.94 & 6.68 & 6.01 & 3.25 & 5.25 & 3.26 & 2.85 & 0.11 & 0.24 & 0.40 & 99.09 \\
\hline 31313 & 736675 & 8539785 & 36 & quartz porphyry & Unango Complex & 74.99 & 0.33 & 12.54 & 1.66 & 1.49 & 0.11 & 0.27 & 4.06 & 4.90 & 0.08 & 0.07 & 0.17 & 99.16 \\
\hline 31244 & 745306 & 8492000 & 36 & Pale grey granodioritic gneiss & Unango Complex & 66.13 & 0.54 & 15.20 & 4.58 & 4.12 & 1.80 & 3.90 & 3.36 & 2.57 & 0.10 & 0.11 & 0.57 & 98.87 \\
\hline 33598 & 748853 & 8187242 & 36 & Amphibolite/metagabbro & Unango Complex & 47.69 & 1.97 & 13.83 & 16.71 & 15.04 & 5.51 & 7.41 & 2.90 & 1.39 & 0.29 & 0.30 & 0.16 & 98.17 \\
\hline 33579 & 750065 & 8174161 & 36 & Metagabbro/ultramafics & Unango Complex & 50.80 & 0.80 & 13.88 & 11.97 & 10.77 & 8.85 & 10.86 & 2.25 & 0.47 & 0.20 & 0.09 & 0.29 & 100.44 \\
\hline 31262 & 750417 & 8559106 & 36 & Granite & Unango Complex & 77.15 & 0.14 & 12.05 & 0.65 & 0.59 & 0.07 & 0.43 & 3.46 & 4.60 & $<0.01$ & 0.02 & 0.27 & 98.85 \\
\hline 31215 & 750565 & 8471495 & 36 & Amphibolite?, plagioclase rich, & Unango Complex & 51.96 & 1.53 & 15.47 & 14.82 & 13.34 & 1.71 & 4.79 & 4.25 & 2.75 & 0.30 & 0.76 & -0.07 & 98.26 \\
\hline 33578 & 752917 & 8180764 & 36 & Metagabbro/ultramafics & Unango Complex & 41.50 & 1.86 & 14.79 & 19.14 & 17.23 & 7.82 & 14.95 & 0.70 & 0.22 & 0.32 & 0.16 & -0.18 & 101.28 \\
\hline 31898 & 755753 & 8642594 & 36 & Granite & Unango Complex & 78.41 & 0.05 & 11.77 & 0.56 & 0.50 & 0.12 & 0.82 & 3.41 & 4.09 & 0.02 & 0.02 & 0.29 & 99.56 \\
\hline 31833 & 758179 & 8608226 & 36 & Pyroxene-gabbro & Unango Complex & 50.07 & 0.78 & 4.92 & 11.38 & 10.24 & 16.05 & 15.27 & 0.54 & 0.10 & 0.22 & 0.05 & 0.38 & 99.78 \\
\hline 31828 & 759233 & 8597152 & 36 & Quartz-feldsp argneiss & Unango Complex & 75.21 & 0.17 & 13.05 & 1.46 & 1.31 & 0.16 & 0.87 & 3.42 & 4.96 & 0.05 & 0.04 & 0.26 & 99.65 \\
\hline 33562 & 759561 & 8196993 & 36 & Precambrian syenite & Unango Complex & 59.95 & 1.14 & 16.47 & 5.41 & 4.87 & 1.11 & 2.26 & 4.51 & 6.01 & 0.18 & 0.40 & 0.91 & 98.35 \\
\hline 31277 & 759649 & 8509634 & 36 & Migmatitic granitic orthogneiss & Unango Complex & 71.97 & 0.32 & 13.75 & 1.90 & 1.71 & 0.41 & 1.31 & 3.51 & 4.86 & 0.05 & 0.07 & 0.24 & 98.39 \\
\hline 31220 & 759926 & 8477771 & 36 & Grey, charnockitic gneiss with & Unango Complex & 55.96 & 1.45 & 17.86 & 6.23 & 5.61 & 1.82 & 3.82 & 5.17 & 4.58 & 0.11 & 0.56 & 0.24 & 97.81 \\
\hline 31790 & 760473 & 8620032 & 36 & q-pl-granofels & Unango Complex & 74.91 & 0.30 & 12.95 & 1.47 & 1.32 & 0.17 & 0.44 & 3.62 & 5.27 & 0.06 & 0.03 & 0.14 & 99.36 \\
\hline 33581 & 761480 & 8188906 & 36 & Metagabbro/ultramafics & Unango Complex & 51.93 & 0.29 & 3.55 & 8.84 & 7.96 & 18.61 & 14.77 & 0.83 & 0.20 & 0.20 & 0.03 & 0.37 & 99.62 \\
\hline 33582 & 761480 & 8188906 & 36 & Metagabbro/ultramafics & Unango Complex & 35.91 & 0.06 & 0.93 & 14.84 & 13.36 & 34.95 & 0.10 & $<0.1$ & 0.02 & 0.13 & 0.03 & 11.86 & 98.84 \\
\hline 31826 & 763258 & 8600342 & 36 & Quartz-feldspar gneiss & Unango Complex & 76.58 & 0.17 & 12.13 & 1.23 & 1.11 & 0.12 & 0.57 & 3.13 & 4.86 & $<0.01$ & 0.04 & 0.99 & 99.82 \\
\hline 33591 & 763318 & 8202216 & 36 & Grey fedspar augen gneiss & Unango Complex & 59.33 & 0.89 & 19.17 & 3.54 & 3.19 & 0.93 & 2.79 & 4.39 & 6.52 & 0.05 & 0.24 & 0.30 & 98.16 \\
\hline 31943 & 763450 & 8642296 & 36 & Microgranite/leptite & Unango Complex & 76.95 & 0.11 & 11.90 & 0.26 & 0.23 & 0.09 & 0.18 & 2.20 & 6.87 & $<0.01$ & 0.03 & 0.34 & 98.94 \\
\hline 31827 & 763963 & 8592848 & 36 & Granitic gneiss & Unango Complex & 77.67 & 0.16 & 11.62 & 1.14 & 1.03 & 0.14 & 0.59 & 3.07 & 4.37 & 0.05 & 0.01 & 0.23 & 99.05 \\
\hline 33590 & 764775 & 8202277 & 36 & Grey fedspar augen gneiss & Unango Complex & 66.30 & 0.62 & 15.51 & 3.24 & 2.92 & 1.02 & 2.26 & 3.84 & 5.63 & 0.05 & 0.25 & 0.26 & 98.97 \\
\hline 33589 & 765330 & 8202319 & 36 & Grey fedspar augen gneiss & Unango Complex & 61.62 & 1.04 & 16.92 & 4.47 & 4.02 & 1.21 & 2.89 & 4.10 & 5.92 & 0.05 & 0.33 & 0.20 & 98.74 \\
\hline 22780 & 765588 & 8469748 & 36 & Metasupracrustal & Unango Complex & 73.41 & 0.98 & 12.67 & 6.07 & 5.46 & 1.49 & 0.69 & 0.69 & 2.00 & 0.10 & 0.04 & 0.43 & 98.57 \\
\hline 31247 & 766306 & 8499462 & 36 & Felsic band in migm granulitic rock & Unango Complex & 65.36 & 0.46 & 16.63 & 3.70 & 3.33 & 1.08 & 3.23 & 5.47 & 1.57 & 0.08 & 0.19 & 0.24 & 98.01 \\
\hline 31784 & 767612 & 8617840 & 36 & px-q-pl-granofels & Unango Complex & 65.18 & 0.52 & 16.74 & 3.90 & 3.51 & 1.03 & 2.96 & 4.70 & 3.39 & 0.09 & 0.19 & 0.28 & 98.99 \\
\hline 31756 & 767799 & 8562646 & 36 & enderbite?, retrogr & Unango Complex & 61.63 & 0.71 & 15.33 & 6.58 & 5.92 & 1.38 & 3.09 & 5.58 & 3.76 & 0.20 & 0.25 & 0.13 & 98.62 \\
\hline 31259 & 771129 & 8481688 & 36 & Basalt dyke in migmatite & Unango Complex & 52.84 & 2.41 & 14.71 & 9.61 & 8.65 & 4.11 & 5.89 & 3.38 & 2.99 & 0.12 & 1.33 & 0.51 & 97.91 \\
\hline 31971 & 771225 & 86456666 & 36 & Granite & Unango Complex & 78.44 & 0.09 & 11.77 & 0.86 & 0.77 & 0.20 & 0.86 & 3.03 & 4.33 & 0.02 & 0.06 & 0.50 & 100.16 \\
\hline 31261 & 774403 & 8486350 & 36 & Migmatitic biotite-gneiss & Unango Complex & 68.43 & 0.31 & 15.81 & 2.79 & 2.51 & 1.00 & 3.29 & 3.71 & 3.15 & 0.05 & 0.09 & 0.33 & 98.95 \\
\hline 31832 & 776259 & 8591372 & 36 & Granitic gneiss & Unango Complex & 68.58 & 0.54 & 15.25 & 2.93 & 2.64 & 0.83 & 2.07 & 4.14 & 4.31 & 0.08 & 0.15 & 0.22 & 99.10 \\
\hline 31203 & 776412 & 8561549 & 36 & Granite, med-gr, weakly foliated & Unango Complex & 63.88 & 0.69 & 14.39 & 5.46 & 4.91 & 1.97 & 2.71 & 4.43 & 4.66 & 0.21 & 0.18 & 0.29 & 98.86 \\
\hline 33580 & 781434 & 8207100 & 36 & Metagabbro/ultramafics & Unango Complex & 48.55 & 1.23 & 6.86 & 11.87 & 10.68 & 16.20 & 12.18 & 0.84 & 0.32 & 0.18 & 0.08 & 0.65 & 98.96 \\
\hline 31210 & 782557 & 8546664 & 36 & Granitic gneiss, hornblende-bearing & Unango Complex & 72.39 & 0.31 & 13.54 & 2.07 & 1.86 & 0.30 & 0.86 & 4.19 & 4.48 & 0.09 & 0.07 & 0.41 & 98.71 \\
\hline 31209 & 782686 & 8547640 & 36 & Diorititic gneiss, Metagranulite? & Unango Complex & 58.68 & 1.53 & 15.50 & 8.03 & 7.23 & 1.89 & 4.11 & 4.05 & 3.08 & 0.15 & 0.43 & 0.73 & 98.18 \\
\hline 31892 & 783532 & 8655884 & 36 & Qurtz-feldspar-biotite-epidote rocks & Unango Complex & 67.56 & 0.51 & 15.36 & 2.91 & 2.62 & 0.92 & 2.37 & 4.11 & 4.24 & 0.08 & 0.17 & 0.63 & 98.85 \\
\hline 31893 & 784778 & 8656136 & 36 & Quartz-K-feldspar porphyroblastic rocks & Unango Complex & 64.86 & 0.86 & 15.60 & 4.36 & 3.92 & 1.92 & 1.84 & 4.40 & 3.18 & 0.10 & 0.28 & 1.79 & 99.19 \\
\hline 31894 & 784778 & 8656136 & 36 & Chlorite schist & Unango Complex & 45.28 & 2.30 & 15.27 & 15.86 & 14.27 & 5.37 & 5.30 & 1.23 & 2.64 & 0.20 & 0.65 & 4.70 & 98.80 \\
\hline 31896 & 785197 & 8656185 & 36 & Andesite & Unango Complex & 62.41 & 0.21 & 18.21 & 5.06 & 4.55 & 0.08 & 0.28 & 6.75 & 5.23 & 0.08 & 0.05 & 0.48 & 98.84 \\
\hline \multirow[t]{2}{*}{31895} & 785197 & 8656185 & 36 & Interbedded quartz-schist, chlorite schist, & & & & & & & & & & & & & & \\
\hline & & & & K-feldspar augen gneiss & Unango Complex & 63.10 & 0.85 & 13.30 & 9.65 & 8.69 & 0.37 & 1.93 & 3.95 & 4.29 & 0.20 & 0.21 & 0.68 & 98.53 \\
\hline
\end{tabular}




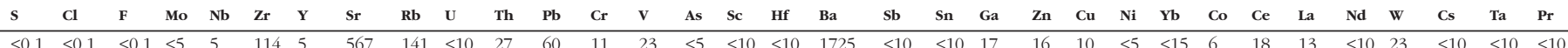

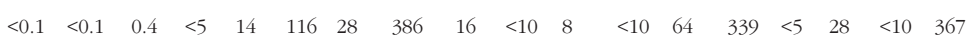

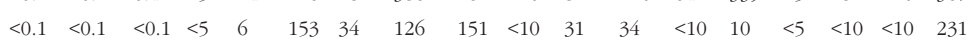
$\begin{array}{llllllllllllllllll}<0.1 & <0.1 & <0.1 & <5 & 5 & 39 & 22 & 172 & 20 & <10 & 6 & <10 & 21 & 10 & <5 & 20 & <10 & 1872\end{array}$ $\begin{array}{llllllllllllllllll}<0.1 & <0.1 & 1.48 & <5 & 5 & 28 & 5 & 8 & 11 & <10 & 13 & <10 & 1089 & 5719 & <5 & <10 & 29 & <10\end{array}$ $\begin{array}{llllllllllllllllll}0.10 & <0.1 & 0.52 & <5 & 21 & 192 & 29 & 531 & 12 & <10 & 5 & <10 & 109 & 284 & 5 & 37 & <10 & 359\end{array}$ $\begin{array}{llllllllllllllllll}<0.1 & <0.1 & 0.37 & <5 & 27 & 351 & 29 & 2262 & 71 & <10 & 12 & 47 & 13 & 140 & <5 & 21 & 42 & 3592\end{array}$ $\begin{array}{llllllllllllllllll}<0.1 & <0.1 & <0.1 & <5 & 8 & 134 & 5 & 296 & 272 & <10 & 28 & 77 & 18 & 13 & <5 & <10 & <10 & 947\end{array}$ $\begin{array}{llllllllllllllllll}<0.1 & <0.1 & 0.32 & <5 & 17 & 170 & 27 & 418 & 14 & <10 & <5 & <10 & 217 & 246 & <5 & 37 & 12 & 290\end{array}$ $\begin{array}{llllllllllllllllll}<0.1 & 0.10 & 0.16 & <5 & 7 & 22 & 50 & 247 & 22 & <10 & <5 & <10 & 16 & 43 & <5 & 24 & <10 & 1875\end{array}$ $\begin{array}{llllllllllllllllll}<0.1 & <0.1 & 0.28 & <5 & 5 & 91 & 37 & 137 & 8 & <10 & 5 & <10 & 161 & 470 & <5 & 54 & <10 & 980\end{array}$ $\begin{array}{llllllllllllllllll}<0.1 & <0.1 & 0.5 & <5 & 30 & 538 & 35 & 888 & 144 & <10 & 31 & 17 & 46 & 123 & <5 & 13 & 25 & 4434\end{array}$

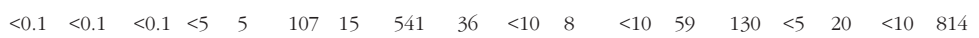
$\begin{array}{llllllllllllllllll}<0.1 & <0.1 & <0.1 & <5 & 9 & 234 & 31 & 278 & 67 & <10 & 13 & <10 & 13 & 25 & <5 & <10 & <10 & 752\end{array}$ $\begin{array}{llllllllllllllllll}<0.1 & <0.1 & <0.1 & <5 & 7 & 211 & 24 & 535 & 85 & <10 & 10 & 12 & 52 & 86 & <5 & 22 & <10 & 715\end{array}$ $\begin{array}{llllllllllllllllll}0.10 & <0.1 & 0.55 & <5 & 32 & 246 & 39 & 450 & 21 & <10 & <5 & <10 & 56 & 338 & <5 & 33 & 12 & 561\end{array}$

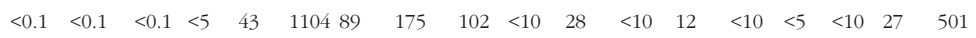
$\begin{array}{llllllllllllllllll}<0.1 & <0.1 & <0.1 & <5 & 5 & <5 & 5 & 829 & <5 & <10 & <5 & <10 & 275 & 43 & <5 & 22 & <10 & 176\end{array}$ $\begin{array}{llllllllllllllllll}<0.1 & <0.1 & 0.42 & <5 & 26 & 344 & 44 & 1288 & 45 & <10 & 5 & 16 & 106 & 191 & <5 & 29 & 22 & 1768\end{array}$ $\begin{array}{lllllllllllllllllll}<0.1 & <0.1 & 0.29 & <5 & 28 & 353 & 42 & 1141 & 57 & <10 & <5 & 11 & 101 & 196 & 7 & 24 & 16 & 1736\end{array}$ $\begin{array}{llllllllllllllllll}<0.1 & <0.1 & <0.1 & <5 & 5 & 67 & 24 & 546 & 57 & <10 & 6 & 17 & 108 & 118 & <5 & 22 & <10 & 777\end{array}$ $\begin{array}{llllllllllllllllll}<0.1 & <0.1 & 0.1 & <5 & 7 & 196 & 23 & 549 & 77 & <10 & 8 & 11 & 126 & 94 & <5 & 15 & <10 & 681\end{array}$

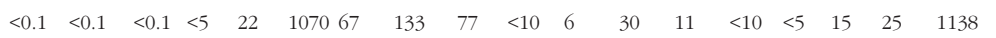
$\begin{array}{clllllllllllllllll}<0.1 & <0.1 & <0.1 & <5 & 7 & 106 & 17 & 1050 & 11 & <10 & <5 & <10 & 41 & 122 & <5 & 21 & 18 & 706\end{array}$ $\begin{array}{llllllllllllllllll}<0.1 & <0.1 & 0.2 & <5 & 125 & 566 & 113 & 154 & 48 & <10 & 21 & <10 & 10 & <10 & <5 & 15 & 16 & 239\end{array}$ $\begin{array}{llllllllllllllllll}<0.1 & <0.1 & <0.1 & <5 & 5 & 94 & 19 & 355 & 18 & <10 & 7 & <10 & 302 & 163 & <5 & 30 & <10 & 298\end{array}$

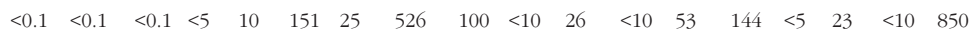
$\begin{array}{llllllllllllllllll}<0.1 & <0.1 & <0.1 & <5 & 10 & 192 & 91 & 60 & 75 & <10 & 6 & <10 & 11 & 17 & <5 & 10 & <10 & 346\end{array}$

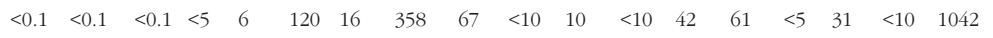
$\begin{array}{llllllllllllllllll}<0.1 & <0.1 & <0.1 & <5 & 6 & 67 & 41 & 217 & 22 & <10 & <5 & <10 & 45 & 382 & <5 & 49 & <10 & 306\end{array}$ $\begin{array}{llllllllllllllllll}0.11 & <0.1 & <0.1 & <5 & <5 & 37 & 17 & 487 & 9 & <10 & <5 & <10 & 353 & 270 & <5 & 34 & <10 & 166\end{array}$ $\begin{array}{llllllllllllllllll}<0.1 & <0.1 & <0.1 & <5 & 5 & 108 & 5 & 43 & 73 & <10 & 10 & 11 & 13 & 10 & <5 & <10 & <10 & 457\end{array}$ $\begin{array}{llllllllllllllllll}<0.1 & <0.1 & 0.25 & 6 & 77 & 531 & 95 & 473 & 49 & <10 & 9 & <10 & <10 & 21 & <5 & 24 & 26 & 1379\end{array}$ $\begin{array}{llllllllllllllllll}<0.1 & <0.1 & <0.1 & <5 & 5 & 83 & 39 & 88 & 5 & <10 & 10 & <10 & 135 & 499 & <5 & 53 & <10 & 48\end{array}$ $\begin{array}{llllllllllllllllll}<0.1 & <0.1 & <0.1 & <5 & 5 & 102 & 5 & 195 & 57 & <10 & 19 & <10 & 10 & 10 & <5 & <10 & <10 & 1031\end{array}$ $\begin{array}{llllllllllllllllll}<0.1 & <0.1 & 0.16 & <5 & 5 & 39 & 17 & 97 & <5 & <10 & 7 & <10 & 468 & 266 & 5 & 70 & <10 & 144\end{array}$ $\begin{array}{llllllllllllllllll}<0.1 & <0.1 & <0.1 & <5 & 5 & 148 & 13 & 67 & 98 & <10 & 7 & <10 & 16 & 10 & <5 & 18 & <10 & 478\end{array}$ $\begin{array}{llllllllllllllllll}<0.1 & <0.1 & 0.11 & <5 & 34 & 587 & 51 & 240 & 145 & <10 & 11 & 44 & <10 & 22 & <5 & 11 & 42 & 2003\end{array}$ $\begin{array}{llllllllllllllllll}<0.1 & <0.1 & <0.1 & <5 & 6 & 241 & 18 & 263 & 137 & <10 & 11 & 14 & 18 & 24 & <5 & 10 & <10 & 1396\end{array}$ $\begin{array}{llllllllllllllllll}<0.1 & <0.1 & 0.18 & <5 & 28 & 656 & 39 & 1265 & 65 & <10 & 9 & 23 & <10 & 52 & <5 & 16 & 22 & 4509\end{array}$ $\begin{array}{llllllllllllllllll}<0.1 & <0.1 & <0.1 & <5 & 5 & 198 & 5 & 14 & 43 & <10 & 13 & <10 & 14 & <10 & <5 & 15 & <10 & 900\end{array}$ $\begin{array}{llllllllllllllllll}<0.1 & <0.1 & <0.1 & <5 & <5 & 19 & 8 & 80 & <5 & <10 & 7 & <10 & 970 & 172 & <5 & 42 & <10 & 64\end{array}$ $\begin{array}{llllllllllllllllll}<0.1 & <0.1 & <0.1 & <5 & <5 & 11 & <5 & <5 & <5 & <10 & 9 & <10 & 4397 & 43 & <5 & <10 & <10 & 28\end{array}$ $\begin{array}{llllllllllllllllll}0.47 & <0.1 & <0.1 & <5 & 8 & 134 & 14 & 92 & 170 & <10 & 10 & 12 & 11 & 12 & <5 & <10 & <10 & 398\end{array}$

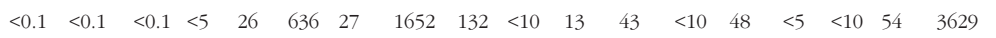
$\begin{array}{llllllllllllllllll}<0.1 & <0.1 & <0.1 & <5 & 5 & 80 & 5 & 151 & 169 & <10 & 33 & 18 & 15 & <10 & <5 & <10 & <10 & 789\end{array}$ $\begin{array}{llllllllllllllllll}<0.1 & <0.1 & <0.1 & <5 & 5 & 126 & 5 & 91 & 67 & <10 & 8 & 134 & 14 & 14 & <5 & <10 & <10 & 809\end{array}$ $\begin{array}{cccccccccccccccccc}<0.1 & <0.1 & <0.1 & <5 & 21 & 274 & 17 & 889 & 184 & <10 & 24 & 40 & <10 & 48 & <5 & 10 & <10 & 2000\end{array}$ $\begin{array}{llllllllllllllllll}<0.1 & <0.1 & <0.1 & <5 & 19 & 376 & 24 & 1047 & 104 & <10 & 8 & 20 & <10 & 43 & <5 & <10 & 22 & 2470\end{array}$ $\begin{array}{llllllllllllllllll}0.28 & <0.1 & <0.1 & <5 & 18 & 285 & 27 & 94 & 76 & <10 & 13 & <10 & 155 & 105 & <5 & 17 & <10 & 503\end{array}$ $\begin{array}{llllllllllllllllll}<0.1 & <0.1 & <0.1 & <5 & 5 & 144 & 6 & 556 & 34 & <10 & 6 & 10 & 15 & 35 & <5 & 12 & <10 & 806\end{array}$ $\begin{array}{llllllllllllllllll}<0.1 & <0.1 & <0.1 & <5 & 5 & 228 & 15 & 457 & 46 & <10 & 5 & <10 & 18 & 44 & <5 & 15 & <10 & 2484\end{array}$ $<0.1<0.1 \quad<0.1<5 \quad 9 \quad 131 \quad 48$ $<0.1 \quad 0.11 \quad 0.38<5 \quad 32 \quad 488 \quad 40$ $<0.1<0.1 \quad<0.1<5 \quad 5 \quad 75 \quad 5$ $<0.1<0.1 \quad<0.1<5 \quad 5 \quad 44 \quad 5$ $<0.1<0.1 \quad<0.1<5 \quad 7 \quad 188 \quad 23$ $\begin{array}{lllllll}<0.1 & <0.1 & <0.1 & <5 & 10 & 259 & 91\end{array}$ $0.15<0.1<0.1<5 \quad<5 \quad 68 \quad 15$ $<0.1<0.1 \quad<0.1<5 \quad 9 \quad 304 \quad 38$ $<0.1<0.1 \quad 0.13<5 \quad 13 \quad 273 \quad 60$ $<0.1<0.1 \quad<0.1<5 \quad 10 \quad 151 \quad 31$ $<0.1<0.1 \quad 0.24<5 \quad 13 \quad 242 \quad 32$ $<0.1<0.1 \quad 0.82<5 \quad 13 \quad 135 \quad 34$ $<0.1<0.1 \quad<0.1<5 \quad 109 \quad 554 \quad 31$

\section{$<10 \quad<10 \quad 14$} $\begin{array}{lllllllllllllll}<10 & <10 & 23 & 73 & 13 & <5 & <15 & 7 & 20 & <10 & 19 & 16 & <10 & <10 & <10\end{array}$

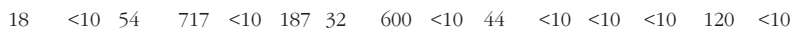
$\begin{array}{lllllllllllllll}<10 & <10 & 14 & 128 & 44 & 79 & <15 & 61 & 66 & 35 & 35 & <10 & <10 & 14 & 11\end{array}$ $\begin{array}{lllllllllllllll}<10 & <10 & 20 & 133 & 22 & 8 & <15 & 18 & 350 & 146 & 143 & <10 & <10 & <10 & 32\end{array}$ $\begin{array}{lllllllllllllll}<10 & <10 & 22 & 31 & 11 & <5 & <15 & <5 & 30 & 22 & 19 & 33 & 14 & <10 & <10\end{array}$ $\begin{array}{lllllllllllllll}<10 & <10 & 21 & 96 & 70 & 70 & <15 & 51 & 45 & 27 & 33 & <10 & <10 & <10 & <10\end{array}$ $\begin{array}{lllllllllllllll}<10 & <10 & 25 & 211 & 21 & <5 & <15 & 17 & 61 & 26 & 59 & 16 & <10 & <10 & <10\end{array}$ $\begin{array}{lllllllllllllll}<10 & <10 & 17 & 83 & 222 & 62 & <15 & 60 & <10 & 14 & <10 & <10 & <10 & <10 & <10\end{array}$ $\begin{array}{lllllllllllllll}<10 & <10 & 15 & 94 & 23 & 14 & <15 & 17 & 326 & 166 & 135 & <10 & <10 & <10 & 22\end{array}$ $\begin{array}{lllllllllllllll}<10 & <10 & 15 & 77 & 29 & 8 & <15 & 18 & 24 & 19 & 21 & 22 & <10 & <10 & <10\end{array}$ $\begin{array}{lllllllllllllll}<10 & <10 & 14 & 93 & 16 & <5 & <15 & 8 & 46 & 19 & 32 & 24 & <10 & <10 & <10\end{array}$ $\begin{array}{lllllllllllllll}<10 & <10 & 16 & 62 & 33 & 19 & <15 & 15 & 44 & 26 & 22 & 18 & <10 & <10 & <10\end{array}$ $\begin{array}{lllllllllllllll}<10 & <10 & 16 & 148 & 37 & 24 & <15 & 59 & 133 & 35 & 54 & <10 & <10 & 17 & 12\end{array}$ $\begin{array}{lllllllllllllll}<10 & <10 & 16 & 48 & 13 & <5 & <15 & <5 & 262 & 136 & 119 & 12 & <10 & <10 & 31\end{array}$ $\begin{array}{lllllllllllllll}<10 & <10 & 13 & 36 & 25 & 100 & <15 & 31 & <10 & <10 & <10 & 15 & <10 & <10 & <10\end{array}$ $\begin{array}{lllllllllllllll}<10 & <10 & 22 & 132 & 34 & 57 & <15 & 37 & 198 & 82 & 105 & <10 & 12 & 10 & 24\end{array}$ $\begin{array}{lllllllllllllll}<10 & <10 & 16 & 158 & 32 & 51 & <15 & 37 & 205 & 70 & 103 & <10 & <10 & <10 & 12\end{array}$ $\begin{array}{lllllllllllllll}<10 & <10 & 14 & 74 & 38 & 26 & <15 & 21 & 19 & 17 & 12 & 24 & <10 & <10 & <10\end{array}$ $\begin{array}{lllllllllllllll}<10 & <10 & 12 & 68 & 23 & 22 & <15 & 19 & 52 & 24 & 31 & 20 & <10 & <10 & <10\end{array}$ $\begin{array}{lllllllllllllll}<10 & <10 & 20 & 159 & <10 & <5 & <15 & 8 & 111 & 63 & 84 & 10 & <10 & <10 & 13\end{array}$ $\begin{array}{lllllllllllllll}<10 & <10 & 15 & 76 & 39 & 20 & <15 & 21 & 30 & 29 & 19 & 11 & <10 & <10 & <10\end{array}$ $\begin{array}{lllllllllllllll}<10 & <10 & 23 & 331 & <10 & <5 & <15 & 7 & 220 & 113 & 107 & 15 & <10 & 10 & 24\end{array}$ $\begin{array}{lllllllllllllll}<10 & <10 & <10 & 67 & 84 & 128 & <15 & 42 & 25 & 17 & 18 & 19 & <10 & <10 & <10\end{array}$ $\begin{array}{lllllllllllllll}<10 & <10 & 17 & 75 & 41 & 18 & <15 & 20 & 102 & 58 & 46 & 16 & <10 & <10 & 14\end{array}$ $\begin{array}{lllllllllllllll}<10 & <10 & 17 & 53 & <10 & <5 & <15 & 6 & 51 & 26 & 39 & 31 & <10 & <10 & <10\end{array}$ $\begin{array}{lllllllllllllll}<10 & <10 & 12 & 67 & <10 & <5 & <15 & 14 & 27 & 12 & 23 & 26 & <10 & <10 & <10\end{array}$ $\begin{array}{lllllllllllllll}11 & <10 & <10 & 125 & 22 & <5 & <15 & 55 & 21 & 20 & 17 & <10 & <10 & 28 & 12\end{array}$

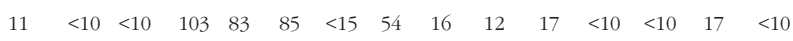
$\begin{array}{lllllllllllllll}<10 & <10 & 10 & 18 & 12 & <5 & <15 & <5 & <10 & <10 & 12 & 33 & <10 & <10 & <10\end{array}$ $\begin{array}{lllllllllllllll}<10 & <10 & 26 & 211 & 21 & <5 & <15 & 31 & 224 & 98 & 131 & <10 & 14 & 13 & 38\end{array}$ $\begin{array}{lllllllllllllll}<10 & <10 & <10 & 98 & 75 & 50 & <15 & 79 & 30 & <10 & 31 & <10 & <10 & 18 & <10\end{array}$ $\begin{array}{lllllllllllllll}<10 & <10 & <10 & 11 & <10 & <5 & <15 & 5 & <10 & <10 & <10 & 23 & <10 & <10 & <10\end{array}$ $\begin{array}{lllllllllllllll}<10 & <10 & <10 & 75 & 178 & 302 & <15 & 72 & <10 & <10 & 12 & <10 & <10 & <10 & <10\end{array}$ $\begin{array}{lllllllllllllll}<10 & <10 & <10 & 32 & 12 & <5 & <15 & 5 & 17 & 17 & 19 & 31 & <10 & <10 & <10\end{array}$ $\begin{array}{lllllllllllllll}<10 & <10 & 10 & 154 & 15 & <5 & <15 & 7 & 200 & 94 & 77 & 10 & <10 & <10 & 25\end{array}$ $\begin{array}{lllllllllllllll}<10 & <10 & <10 & 33 & 15 & <5 & <15 & 6 & 33 & 24 & 19 & 22 & <10 & <10 & <10\end{array}$ $\begin{array}{lllllllllllllll}<10 & <10 & 20 & 127 & 15 & <5 & <15 & 11 & 183 & 90 & 91 & 12 & 11 & <10 & 22\end{array}$ $\begin{array}{lllllllllllllll}<10 & <10 & 11 & 32 & 12 & <5 & <15 & 5 & 18 & 18 & <10 & 23 & <10 & <10 & <10\end{array}$ $\begin{array}{lllllllllllllll}<10 & <10 & <10 & 62 & 15 & 135 & <15 & 53 & <10 & <10 & <10 & <10 & <10 & <10 & <10\end{array}$ $\begin{array}{llllllllllllll}<10 & <10 & <10 & 58 & <10 & 1947<15 & 180 & <10 & <10 & <10 & <10 & <10 & <10 & 10\end{array}$ $\begin{array}{lllllllllllllll}<10 & <10 & 10 & 8 & <10 & <5 & <15 & <5 & 30 & 28 & 13 & 64 & <10 & <10 & <10\end{array}$ $\begin{array}{lllllllllllllll}<10 & <10 & 15 & 67 & 23 & <5 & <15 & 8 & 199 & 98 & 67 & 11 & 16 & 10 & 20\end{array}$ $\begin{array}{lllllllllllllll}<10 & <10 & <10 & 13 & 11 & <5 & <15 & <5 & 18 & <10 & <10 & 27 & <10 & <10 & <10\end{array}$ $\begin{array}{lllllllllllllll}<10 & <10 & <10 & 79 & <10 & <5 & <15 & 7 & 12 & 15 & <10 & 26 & <10 & <10 & <10\end{array}$ $\begin{array}{lllllllllllllll}<10 & <10 & 13 & 57 & 22 & <5 & <15 & 12 & 141 & 81 & 45 & 13 & 10 & 12 & 20\end{array}$ $\begin{array}{lllllllllllllll}<10 & <10 & 13 & 75 & 18 & <5 & <15 & 9 & 181 & 91 & 74 & <10 & 13 & <10 & 17\end{array}$ $\begin{array}{lllllllllllllll}<10 & <10 & 12 & 64 & 18 & 38 & <15 & 22 & 42 & 28 & 18 & 32 & <10 & <10 & <10\end{array}$ $\begin{array}{lllllllllllllll}<10 & <10 & 10 & 63 & 12 & <5 & <15 & 7 & 28 & 18 & 12 & 19 & <10 & <10 & <10\end{array}$ $\begin{array}{lllllllllllllll}<10 & <10 & 15 & 69 & 10 & <5 & <15 & 6 & 34 & 18 & 15 & 22 & <10 & <10 & <10\end{array}$ $\begin{array}{lllllllllllllll}<10 & <10 & 12 & 103 & 15 & <5 & <15 & 13 & 53 & 31 & 24 & 15 & <10 & <10 & <10\end{array}$ $\begin{array}{lllllllllllllll}<10 & <10 & 20 & 146 & 26 & 30 & <15 & 19 & 263 & 127 & 115 & <10 & 12 & 14 & 23\end{array}$ $\begin{array}{lllllllllllllll}<10 & <10 & <10 & 20 & 12 & <5 & <15 & 5 & 28 & 36 & 14 & 31 & <10 & <10 & <10\end{array}$ $\begin{array}{lllllllllllllll}<10 & <10 & <10 & 40 & 19 & <5 & <15 & 9 & <10 & 20 & 15 & 26 & <10 & <10 & <10\end{array}$ $\begin{array}{lllllllllllllll}<10 & <10 & <10 & 51 & <10 & <5 & <15 & 7 & 33 & 20 & 23 & 27 & <10 & <10 & <10\end{array}$ $\begin{array}{lllllllllllllll}<10 & <10 & 14 & 103 & 28 & 15 & <15 & 11 & 121 & 44 & 59 & 30 & <10 & <10 & 11\end{array}$ $\begin{array}{lllllllllllllll}10 & 11 & <10 & 90 & 33 & 177 & <15 & 66 & 19 & <10 & 23 & <10 & <10 & 15 & <10\end{array}$ $\begin{array}{lllllllllllllll}<10 & <10 & 12 & 68 & 10 & <5 & <15 & <5 & 74 & 30 & 27 & 25 & <10 & <10 & <10\end{array}$ $\begin{array}{lllllllllllllll}<10 & <10 & 17 & 107 & 28 & <5 & <15 & 22 & 122 & 58 & 57 & 15 & 11 & <10 & <10\end{array}$ $\begin{array}{lllllllllllllll}<10 & <10 & 11 & 49 & 11 & <5 & <15 & 9 & 29 & 20 & 24 & 19 & <10 & <10 & <10\end{array}$ $\begin{array}{lllllllllllllll}<10 & <10 & 18 & 71 & 13 & <5 & <15 & 19 & 64 & 39 & 31 & 21 & <10 & <10 & <10\end{array}$ $\begin{array}{lllllllllllllll}<10 & <10 & 14 & 155 & 23 & 53 & <15 & 74 & 52 & 26 & 28 & <10 & <10 & 10 & 12\end{array}$ $\begin{array}{lllllllllllllll}<10 & <10 & 15 & 73 & 13 & <5 & <15 & 7 & 130 & 75 & 50 & 18 & <10 & <10 & 15\end{array}$ 


\begin{tabular}{|c|c|c|c|c|c|c|c|c|c|c|c|c|c|c|c|c|c|c|}
\hline Sample & UTM, $\mathbf{E}$ & UTM, $\mathbf{N}$ & Zone & Field name & Tectonic Unit & $\mathrm{SiO}_{2}$ & $\mathrm{TiO}_{2}$ & $\mathrm{Al}_{2} \mathrm{O}_{3}$ & $\mathrm{Fe}_{2} \mathrm{O}_{3}$ & FeOt & MgO & $\mathrm{CaO}$ & $\mathrm{Na}_{2} \mathrm{O}$ & $\mathbf{K}_{2} \mathrm{O}$ & Mno & $\mathbf{P}_{2} \mathrm{O}_{5}$ & Gl.tap & sum \\
\hline 33510 & 787095 & 8435113 & 36 & Charnockitic gneiss & Unango Complex & 73.66 & 0.29 & 12.29 & 2.34 & 2.11 & 0.07 & 0.69 & 3.29 & 5.41 & 0.04 & 0.02 & 0.10 & 98.21 \\
\hline 31897 & 787955 & 8654778 & 36 & Charnokite & Unango Complex & 75.23 & 0.17 & 13.30 & 1.09 & 0.98 & 0.32 & 1.98 & 4.00 & 2.96 & 0.02 & 0.05 & 0.52 & 99.65 \\
\hline 31212 & 788690 & 8558874 & 36 & Brownish granulitic gneiss, fine grained & Unango Complex & 69.57 & 0.43 & 14.36 & 3.01 & 2.71 & 0.59 & 1.46 & 3.58 & 5.19 & 0.06 & 0.12 & 0.75 & 99.12 \\
\hline 31211 & 788959 & 8557434 & 36 & Fine grained granitic gneiss, & Unango Complex & 75.27 & 0.13 & 12.82 & 1.54 & 1.39 & 0.13 & 0.71 & 4.50 & 3.80 & 0.05 & 0.03 & 0.16 & 99.14 \\
\hline 31217 & 790176 & 8461102 & 36 & Granitic gneiss, K-feldspar phyric & Unango Complex & 68.77 & 0.50 & 14.63 & 3.38 & 3.04 & 0.90 & 2.46 & 3.08 & 4.31 & 0.08 & 0.17 & 0.35 & 98.63 \\
\hline 31229 & 793775 & 8526498 & 36 & Migmatitic biotite-granodioritic gneiss & Unango Complex & 72.14 & 0.45 & 12.80 & 3.17 & 2.85 & 0.22 & 0.95 & 3.92 & 5.30 & 0.10 & 0.06 & 0.26 & 99.36 \\
\hline 31202 & 793813 & 8557092 & 36 & Hornblende diorite, med-grained & Unango Complex & 58.78 & 0.73 & 16.82 & 5.59 & 5.03 & 2.75 & 4.43 & 3.52 & 3.50 & 0.11 & 0.22 & 1.80 & 98.25 \\
\hline 31238 & 795362 & 8527310 & 36 & Grey fine-gr quarto-feldspathic gneiss & Unango Complex & 68.80 & 0.56 & 14.00 & 3.48 & 3.13 & 0.27 & 1.29 & 4.39 & 4.90 & 0.12 & 0.10 & 1.02 & 98.92 \\
\hline 31870 & 798031 & 8573358 & 36 & Granodiorite & Unango Complex & 66.49 & 0.48 & 16.67 & 2.85 & 2.57 & 0.74 & 2.07 & 5.09 & 3.81 & 0.06 & 0.16 & 0.60 & 99.02 \\
\hline 31842 & 798317 & 8707936 & 36 & Pyroxene-plagioclase gneiss & Unango Complex & 60.94 & 0.89 & 16.47 & 5.86 & 5.27 & 2.46 & 4.76 & 3.11 & 3.65 & 0.10 & 0.30 & 0.71 & 99.26 \\
\hline 31753 & 799467 & 8573177 & 36 & Med-grained quartzofeldspathic gneiss & Unango Complex & 74.10 & 0.28 & 13.25 & 2.08 & 1.87 & 0.29 & 0.76 & 3.90 & 4.50 & 0.08 & 0.07 & 0.38 & 99.69 \\
\hline 31843 & 799489 & 8711446 & 36 & Gneissic granite & Unango Complex & 72.63 & 0.12 & 12.79 & 2.02 & 1.82 & 0.06 & 1.36 & 3.53 & 4.59 & 0.03 & 0.02 & 0.93 & 98.07 \\
\hline 31776 & 799836 & 8634248 & 36 & foliated granite / quartzofeldspathic gneiss & Unango Complex & 66.17 & 0.41 & 16.68 & 3.19 & 2.87 & 0.93 & 2.47 & 4.87 & 3.95 & 0.08 & 0.17 & 0.82 & 99.75 \\
\hline 31221 & 801478 & 8480199 & 36 & K-feldspar phyric, granitic gneiss & Unango Complex & 72.70 & 0.27 & 12.98 & 1.79 & 1.61 & 0.29 & 1.51 & 3.07 & 5.25 & 0.03 & 0.06 & 0.45 & 98.39 \\
\hline 31772 & 802248 & 8588401 & 36 & tonalite, porphyric & Unango Complex & 65.89 & 0.44 & 15.98 & 3.52 & 3.17 & 1.25 & 3.00 & 4.59 & 3.13 & 0.08 & 0.16 & 0.84 & 98.90 \\
\hline 31773 & 802387 & 8588307 & 36 & granodiorite, porphyric, foliated & Unango Complex & 66.50 & 0.47 & 15.61 & 3.56 & 3.20 & 1.24 & 2.67 & 4.07 & 3.76 & 0.07 & 0.17 & 0.98 & 99.10 \\
\hline 31754 & 803492 & 8582917 & 36 & foliated tonalite & Unango Complex & 68.45 & 0.39 & 15.57 & 2.51 & 2.26 & 1.03 & 2.45 & 4.22 & 3.84 & 0.06 & 0.11 & 0.54 & 99.16 \\
\hline 31251 & 808494 & 8526410 & 36 & Kfeldspar-phyric monzo-granite & Unango Complex & 63.42 & 0.84 & 14.50 & 5.10 & 4.59 & 2.58 & 3.43 & 3.72 & 4.29 & 0.09 & 0.33 & 0.20 & 98.49 \\
\hline 31752 & 813454 & 8584335 & 36 & foliated tonalite & Unango Complex & 67.21 & 0.46 & 15.13 & 3.30 & 2.97 & 1.65 & 2.96 & 3.70 & 3.77 & 0.06 & 0.11 & 0.97 & 99.32 \\
\hline 31223 & 814130 & 8481778 & 36 & Granulitic gneiss & Unango Complex & 66.56 & 0.73 & 15.02 & 4.62 & 4.16 & 0.62 & 3.11 & 3.85 & 3.75 & 0.13 & 0.25 & 0.38 & 99.03 \\
\hline 33573 & 814470 & 8243889 & 36 & Metarhyolite & Unango Complex & 63.04 & 0.50 & 18.14 & 3.06 & 2.75 & 0.26 & 1.01 & 5.63 & 6.73 & 0.11 & 0.07 & 0.23 & 98.79 \\
\hline 31803 & 818090 & 8699075 & 36 & px-pl gneiss & Unango Complex & 61.59 & 1.51 & 13.99 & 8.00 & 7.20 & 1.54 & 3.65 & 3.35 & 4.33 & 0.14 & 0.56 & 0.25 & 98.93 \\
\hline 31237 & 822419 & 8517280 & 36 & Grey fine grained bi-rich gneiss & Unango Complex & 62.73 & 1.00 & 16.46 & 6.82 & 6.14 & 2.97 & 3.88 & 2.79 & 2.58 & 0.08 & 0.06 & 0.37 & 99.74 \\
\hline 31224 & 822967 & 8489034 & 36 & Granulitic orthogneiss, K-feldspar phyric & Unango Complex & 74.51 & 0.30 & 12.47 & 2.10 & 1.89 & 0.35 & 1.35 & 2.55 & 5.04 & 0.03 & 0.08 & 0.32 & 99.12 \\
\hline 35230 & 727598 & 8595436 & 36 & GREENSTONE & Unango Complex & 43.08 & 3.15 & 14.89 & 16.75 & 15.08 & 5.71 & 8.16 & 2.70 & 0.88 & 0.23 & 0.92 & 2.19 & 98.65 \\
\hline 35231 & 731530 & 8599388 & 36 & PHYRIC GREENSTONE. & Unango Complex & 46.29 & 1.68 & 16.50 & 12.32 & 11.09 & 6.56 & 9.11 & 2.18 & 1.03 & 0.22 & 0.19 & 2.51 & 98.59 \\
\hline 33472 & 177075 & 8420431 & 37 & Syenite, Na-rich & Unango Complex & 56.69 & 0.11 & 23.46 & 2.68 & 2.41 & 0.09 & 0.25 & 10.02 & 4.43 & 0.06 & $<0.01$ & 0.26 & 98.05 \\
\hline 37219 & 179929 & 8531824 & 37 & HORNBLENDE GNEISS & Unango Complex & 61.06 & 0.85 & 16.00 & 7.95 & 7.16 & 0.68 & 3.60 & 3.48 & 4.10 & 0.21 & 0.25 & 0.06 & 98.24 \\
\hline 31891 & 180554 & 8710022 & 37 & Granite gneiss & Unango Complex & 73.83 & 0.21 & 13.25 & 1.87 & 1.68 & 0.24 & 1.09 & 3.23 & 5.22 & 0.03 & 0.05 & 0.21 & 99.24 \\
\hline 31890 & 181567 & 8709812 & 37 & Granite & Unango Complex & 75.39 & 0.11 & 13.19 & 1.07 & 0.96 & 0.01 & 0.49 & 3.07 & 6.24 & $<0.01$ & 0.02 & 0.17 & 99.77 \\
\hline 31889 & 182163 & 8709595 & 37 & Granite & Unango Complex & 71.04 & 0.25 & 14.04 & 1.81 & 1.63 & 0.19 & 0.80 & 3.44 & 6.19 & 0.03 & 0.04 & 0.19 & 98.01 \\
\hline 31888 & 183147 & 8709600 & 37 & Augen gneiss & Unango Complex & 61.68 & 0.77 & 17.93 & 4.86 & 4.37 & 1.06 & 2.80 & 4.27 & 5.40 & 0.10 & 0.25 & 0.27 & 99.39 \\
\hline 31960 & 183240 & 8702869 & 37 & Feldspar-phyric rock & Unango Complex & 65.19 & 0.69 & 16.04 & 3.94 & 3.55 & 1.82 & 3.54 & 4.28 & 3.25 & 0.08 & 0.17 & 0.34 & 99.35 \\
\hline \multirow[t]{2}{*}{31887} & 184074 & 8709709 & 37 & Plagioclase-pyroxene-biotite-garnet (quartz) & & & & & & & & & & & & & & \\
\hline & & & & rock (mongerite ?) & Unango Complex & 57.67 & 1.10 & 16.63 & 7.73 & 6.96 & 3.72 & 6.86 & 3.59 & 1.32 & 0.15 & 0.38 & 0.17 & 99.31 \\
\hline 31885 & 184786 & 8709707 & 37 & Garnet-rich quartz-feldspar rock & Unango Complex & 62.02 & 0.75 & 14.70 & 10.37 & 9.33 & 0.29 & 3.34 & 1.75 & 5.50 & 0.38 & 0.22 & 0.05 & 99.37 \\
\hline \multirow[t]{2}{*}{31886} & 184786 & 8709707 & 37 & Plagoclase-biotite-amphibole-quartz & & & & & & & & & & & & & & \\
\hline & & & & garnet-rich rock & Unango Complex & 42.21 & 3.33 & 13.36 & 20.64 & 18.58 & 6.25 & 10.87 & 1.89 & 0.21 & 0.25 & 0.02 & 0.06 & 99.08 \\
\hline 22776 & 185894 & 8548072 & 37 & Mangeritic gneiss & Unango Complex & 57.47 & 1.73 & 15.43 & 8.81 & 7.93 & 2.60 & 4.95 & 3.69 & 2.76 & 0.17 & 0.49 & 0.11 & 98.21 \\
\hline 31884 & 185957 & 8709911 & 37 & Quartz-rich biotite gneiss & Unango Complex & 77.32 & 0.17 & 11.07 & 1.53 & 1.38 & 0.06 & 0.50 & 2.64 & 5.15 & 0.03 & 0.02 & 0.13 & 98.63 \\
\hline 31883 & 186587 & 8709796 & 37 & Biotite granite gneiss & Unango Complex & 62.97 & 0.17 & 19.51 & 3.34 & 3.01 & 0.09 & 0.37 & 7.83 & 4.07 & 0.10 & 0.01 & 0.29 & 98.74 \\
\hline 31946 & 189485 & 8596462 & 37 & Plagioclase porphyry & Unango Complex & 69.53 & 0.64 & 13.95 & 3.64 & 3.28 & 0.77 & 1.90 & 3.88 & 4.32 & 0.10 & 0.17 & 0.15 & 99.06 \\
\hline 34291 & 189718 & 8540660 & 37 & Granitic gneiss & Unango Complex & 69.37 & 0.44 & 14.40 & 2.76 & 2.48 & 0.52 & 1.52 & 3.79 & 5.13 & 0.07 & 0.14 & 0.17 & 98.29 \\
\hline 22782 & 190728 & 8508496 & 37 & Charnockite & Unango Complex & 70.22 & 0.35 & 14.54 & 2.08 & 1.87 & 0.29 & 1.68 & 3.45 & 5.20 & 0.04 & 0.09 & 0.32 & 98.27 \\
\hline 34295 & 191900 & 8553800 & 37 & Quartz monzonite & Unango Complex & 64.77 & 1.06 & 14.72 & 5.36 & 4.82 & 1.15 & 2.94 & 3.85 & 4.14 & 0.11 & 0.29 & 0.14 & 98.54 \\
\hline 31955 & 193760 & 8602002 & 37 & Hornblende-plag-qtz-garnet gneiss & Unango Complex & 59.78 & 0.98 & 16.38 & 8.42 & 7.58 & 0.76 & 2.85 & 5.81 & 2.89 & 0.24 & 0.32 & 0.11 & 98.52 \\
\hline 34273 & 196247 & 8513422 & 37 & Mangeritic gneiss & Unango Complex & 57.88 & 0.98 & 17.08 & 8.46 & 7.61 & 0.82 & 4.36 & 4.86 & 3.31 & 0.28 & 0.37 & -0.10 & 98.30 \\
\hline 22790 & 196949 & 8506256 & 37 & Quartz monzonite & Unango Complex & 65.02 & 0.68 & 16.09 & 3.93 & 3.54 & 0.72 & 2.60 & 4.02 & 4.45 & 0.10 & 0.21 & 0.26 & 98.08 \\
\hline 22788 & 199332 & 8501376 & 37 & Quartz monzonite & Unango Complex & 72.53 & 0.31 & 13.65 & 1.92 & 1.73 & 0.34 & 1.38 & 3.17 & 5.22 & 0.03 & 0.07 & 0.56 & 99.18 \\
\hline 34275 & 199454 & 8509226 & 37 & Augengneiss & Unango Complex & 66.11 & 0.62 & 15.45 & 3.70 & 3.33 & 0.64 & 2.67 & 3.80 & 4.58 & 0.08 & 0.18 & 0.38 & 98.22 \\
\hline 31801 & 201521 & 8655856 & 37 & bio(px)-pl gneiss & Unango Complex & 59.32 & 0.96 & 18.19 & 5.84 & 5.26 & 0.76 & 3.61 & 5.22 & 3.91 & 0.19 & 0.37 & 0.09 & 98.46 \\
\hline 31957 & 204074 & 8575166 & 37 & Quartzitic rock & Unango Complex & 96.52 & 0.05 & 1.06 & 1.27 & 1.14 & 0.05 & 0.02 & $<0.1$ & 0.08 & $<0.01$ & 0.02 & 0.29 & 99.31 \\
\hline 31956 & 204255 & 8576572 & 37 & Granitic Gneiss & Unango Complex & 62.58 & 0.20 & 21.22 & 1.43 & 1.29 & 0.48 & 2.83 & 6.63 & 3.30 & 0.04 & 0.03 & 0.86 & 99.60 \\
\hline 33507 & 206404 & 8370252 & 37 & Mangerite & Unango Complex & 62.40 & 0.75 & 17.95 & 2.67 & 2.40 & 0.53 & 1.43 & 4.01 & 8.17 & 0.06 & 0.13 & 0.18 & 98.27 \\
\hline 31805 & 206967 & 8583214 & 37 & syenite & Unango Complex & 59.28 & 0.50 & 13.97 & 8.15 & 7.34 & 1.78 & 0.69 & 7.44 & 4.72 & 0.09 & 0.53 & 1.79 & 98.93 \\
\hline 31806 & 207210 & 8583830 & 37 & pyroxenite & Unango Complex & 52.54 & 0.27 & 11.65 & 10.49 & 9.44 & 1.83 & 4.85 & 4.46 & 7.72 & 0.31 & 1.06 & 3.03 & 98.21 \\
\hline 31807 & 207210 & 8583830 & 37 & pyroxenite & Unango Complex & 55.64 & 0.21 & 9.44 & 16.86 & 15.17 & 0.67 & 1.62 & 8.75 & 3.70 & 0.30 & 0.20 & 1.10 & 98.50 \\
\hline 31808 & 207210 & 8583830 & 37 & pyroxenite & Unango Complex & 14.94 & 0.06 & 4.04 & 8.40 & 7.56 & 3.89 & 26.98 & 1.07 & 2.20 & 1.52 & 3.84 & 25.87 & 92.82 \\
\hline 31809 & 207763 & 8583888 & 37 & pyroxenite & Unango Complex & 46.07 & 0.14 & 9.91 & 9.98 & 8.98 & 1.38 & 8.57 & 6.62 & 3.12 & 0.86 & 0.74 & 9.99 & 97.38 \\
\hline 31810 & 208206 & 8583982 & 37 & pyroxenite and carbonate-apatite vein & Unango Complex & 10.64 & 0.06 & 2.42 & 5.69 & 5.12 & 4.87 & 27.16 & 1.92 & 0.15 & 2.22 & 11.94 & 21.13 & 88.18 \\
\hline 33594 & 211426 & 8287916 & 37 & Charnockites s.l. & Unango Complex & 59.91 & 0.78 & 17.07 & 6.08 & 5.47 & 0.52 & 2.59 & 4.63 & 6.46 & 0.14 & 0.18 & -0.03 & 98.35 \\
\hline 31835 & 212783 & 8602218 & 37 & Charnockitic gneiss & Unango Complex & 69.28 & 0.50 & 15.07 & 3.58 & 3.22 & 1.69 & 3.00 & 4.57 & 1.95 & 0.11 & 0.15 & 0.76 & 100.65 \\
\hline 33595 & 219462 & 8288506 & 37 & Charnockites s.l. & Unango Complex & 58.36 & 1.03 & 17.03 & 7.06 & 6.35 & 0.81 & 3.89 & 4.80 & 4.51 & 0.16 & 0.31 & 0.05 & 98.00 \\
\hline 33557 & 228390 & 8295133 & 37 & Pan-African granites & Unango Complex & 60.46 & 1.49 & 15.69 & 6.03 & 5.43 & 1.59 & 3.78 & 4.11 & 4.04 & 0.06 & 0.47 & 0.42 & 98.13 \\
\hline 33597 & 228702 & 8300458 & 37 & Charnockites s.l. & Unango Complex & 60.28 & 0.96 & 17.16 & 5.61 & 5.05 & 0.75 & 2.94 & 4.26 & 6.01 & 0.11 & 0.21 & 0.16 & 98.44 \\
\hline 33596 & 230715 & 8304396 & 37 & Charnockites s.l. & Unango Complex & 67.62 & 0.68 & 13.91 & 5.06 & 4.55 & 0.51 & 1.91 & 3.37 & 5.65 & 0.10 & 0.14 & 0.18 & 99.14 \\
\hline 33512 & 231564 & 8361419 & 37 & Garnetiferous banded gneiss & Unango Complex & 67.28 & 0.63 & 14.80 & 4.76 & 4.28 & 2.08 & 3.21 & 3.28 & 2.43 & 0.07 & 0.10 & 0.28 & 98.91 \\
\hline 33499 & 235093 & 8348165 & 37 & Monzogranite -quartz monzonite & Unango Complex & 70.79 & 0.33 & 12.49 & 4.59 & 4.13 & 0.15 & 1.57 & 2.34 & 5.66 & 0.05 & 0.04 & 0.67 & 98.67 \\
\hline 37216 & 241444 & 8641280 & 37 & GRANITIC GNEISS & Unango Complex & 66.52 & 0.83 & 15.20 & 4.66 & 4.19 & 0.63 & 0.77 & 3.45 & 5.86 & 0.14 & 0.26 & 0.78 & 99.10 \\
\hline
\end{tabular}


J. JACOBs, D. JAmal, G. MOTUZA, W. BAuER, E. DAudi, P. Feitio, V. MANhiCA, A. MONIZ AND D. ROSSE

\begin{tabular}{llllllllllllllllllllllllllllllllll}
$\mathbf{S}$ & $\mathbf{C l}$ & $\mathbf{F}$ & $\mathbf{M o}$ & $\mathbf{N b}$ & $\mathbf{Z r}$ & $\mathbf{Y}$ & $\mathbf{S r}$ & $\mathbf{R b}$ & $\mathbf{U}$ & $\mathbf{T h}$ & $\mathbf{P b}$ & $\mathbf{C r}$ & $\mathbf{V}$ & $\mathbf{A s}$ & $\mathbf{S c}$ & $\mathbf{H f}$ & $\mathbf{B a}$ & $\mathbf{S b}$ & $\mathbf{S n}$ & $\mathbf{G a}$ & $\mathbf{Z n}$ & $\mathbf{C u}$ & $\mathbf{N i}$ & $\mathbf{Y b}$ & $\mathbf{C o}$ & $\mathbf{C e}$ & $\mathbf{L a}$ & $\mathbf{N d}$ & $\mathbf{w}$ & $\mathbf{C s}$ & $\mathbf{T a}$ & $\mathbf{P r}$ \\
\hline 0.1 & $<0.1$ & $<0.1$ & $<5$ & 24 & 486 & 110 & 37 & 141 & $<10$ & 17 & 16 & 20 & $<10$ & $<5$ & $<10$ & $<10$ & 338 & $<10$ & $<10$ & 16 & 58 & $<10$ & 7 & $<15$ & $<5$ & 124 & 73 & 57 & 37 & $<10$ & $<10$ & 12
\end{tabular}

$<0.1<0.1<0.1<5 \quad 5 \quad 61$

$\begin{array}{llllllllllllllllll}<0.1 & <0.1 & 0.1 & <5 & 13 & 441 & 47 & 217 & 212 & <10 & 14 & 20 & 19 & 38 & <5 & 12 & 11 & 1093\end{array}$

$\begin{array}{llllllllllllllllllll}<0.1 & <0.1 & <5 & 18 & 154 & 47 & 304 & 163 & <10 & 18 & 15 & 50 & 51 & <5 & 19 & <10 & 1231 & <10 & <10 & 13\end{array}$

$\begin{array}{llllllllllllllllll}<0.1 & <0.1 & <0.1 & <5 & 19 & 558 & 61 & 49 & 126 & <10 & 11 & 12 & 26 & <10 & <5 & 15 & <10 & 440\end{array}$

$\begin{array}{llllllllllllllllll}<.1 & <0.1 & 0.17 & <5 & 7 & 132 & 43 & 564 & 96 & <10 & 9 & <10 & 39 & 104 & <5 & 14 & <10 & 1187\end{array}$

$\begin{array}{llllllllllllllllll}<0.1 & <0.1 & <0.1 & <5 & 21 & 560 & 80 & 87 & 127 & <10 & 18 & 18 & 16 & 11 & <5 & 17 & 14 & 717\end{array}$

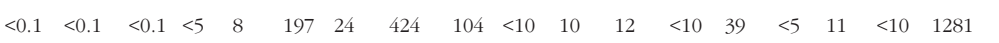

$\begin{array}{llllllllllllllllll}<0.1 & <0.1 & 0.16 & <5 & 9 & 174 & 20 & 553 & 102 & <10 & 6 & 19 & 67 & 116 & <5 & 20 & <10 & 1342\end{array}$

$\begin{array}{cccccccccccccccccc}<0.1 & <0.1 & <0.1 & <5 & 5 & 181 & 7 & 105 & 118 & <10 & 17 & 28 & 31 & 10 & <5 & <10 & <10 & 726\end{array}$ $\begin{array}{llllllllllllllllll}<0.1 & <0.1 & 0.41 & <5 & 117 & 180 & 129 & 55 & 292 & 19 & 62 & 30 & 12 & <10 & <5 & <10 & <10 & 97\end{array}$

$\begin{array}{llllllllllllllllll}<0.1 & <0.1 & <0.1 & <5 & 7 & 151 & 33 & 385 & 111 & <10 & 10 & 22 & 24 & 45 & <5 & <10 & <10 & 1528\end{array}$

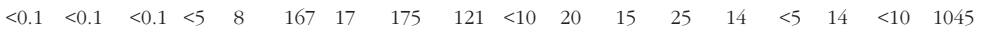
$\begin{array}{llllllllllllllllll}<0.1 & <0.1 & <0.1 & <5 & 11 & 129 & 21 & 452 & 216 & <10 & 15 & 18 & 41 & 61 & <5 & 10 & <10 & 920\end{array}$ $\begin{array}{llllllllllllllllll}<0.1 & <0.1 & <0.1 & <5 & 7 & 142 & 28 & 433 & 149 & <10 & 11 & <10 & 39 & 52 & <5 & 11 & <10 & 912\end{array}$ $\begin{array}{llllllllllllllllll}<0.1 & <0.1 & <0.1 & <5 & 6 & 114 & 14 & 387 & 108 & <10 & 9 & 15 & 21 & 42 & <5 & <10 & <10 & 848\end{array}$ $\begin{array}{llllllllllllllllll}<0.1 & <0.1 & <0.1 & <5 & 10 & 192 & 25 & 430 & 140 & <10 & 11 & 16 & 136 & 120 & <5 & 16 & <10 & 1017\end{array}$

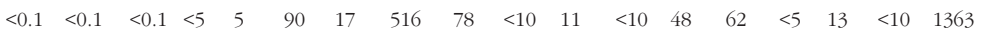

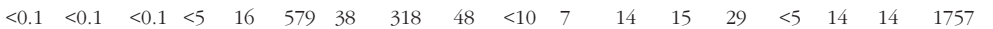
$\begin{array}{llllllllllllllllll}<0.1 & <0.1 & <0.1 & <5 & 51 & 751 & 25 & 29 & 125 & <10 & 55 & 37 & <10 & <10 & <5 & <10 & 56 & 123\end{array}$ $\begin{array}{llllllllllllllllll}<0.1 & <0.1 & 0.17 & 5 & 23 & 551 & 82 & 267 & 117 & <10 & 10 & 19 & 38 & 88 & <5 & 14 & 18 & 1094\end{array}$ $\begin{array}{llllllllllllllllll}<0.1 & <0.1 & <0.1 & <5 & 13 & 131 & 5 & 488 & 93 & <10 & 25 & 12 & 149 & 115 & <5 & 17 & <10 & 1168\end{array}$ $\begin{array}{llllllllllllllllll}<0.1 & <0.1 & <0.1 & <5 & 6 & 194 & 18 & 157 & 119 & <10 & 12 & 15 & <10 & 19 & <5 & 19 & <10 & 778\end{array}$ $\begin{array}{llllllllllllllllll}<0.1 & <0.1 & 0.26 & <5 & 19 & 95 & 32 & 513 & 25 & <10 & <5 & <10 & 44 & 262 & <5 & 28 & <10 & 490\end{array}$ $\begin{array}{llllllllllllllllll}<0.1 & <0.1 & 0.23 & <5 & 6 & 58 & 18 & 449 & 31 & <10 & 6 & <10 & 76 & 168 & <5 & 33 & <10 & 438\end{array}$

$\begin{array}{llllllllllllllllll}<0.1 & <0.1 & <0.1 & <5 & 17 & 1188 & 45 & 381 & 65 & <10 & 5 & 11 & <10 & 39 & <5 & 22 & 44 & 2822\end{array}$ $\begin{array}{llllllllllllllllll}<0.1 & <0.1 & <0.1 & <5 & 5 & 208 & 5 & 319 & 75 & <10 & 6 & <10 & 25 & 22 & <5 & 13 & <10 & 969\end{array}$ $\begin{array}{llllllllllllllllll}<0.1 & <0.1 & <0.1 & <5 & 5 & 204 & 5 & 28 & 140 & <10 & 12 & 16 & 11 & <10 & <5 & <10 & <10 & 120\end{array}$ $\begin{array}{llllllllllllllllll}<0.1 & <0.1 & <0.1 & <5 & 8 & 294 & 24 & 81 & 102 & <10 & 10 & 13 & 14 & <10 & <5 & 17 & <10 & 437\end{array}$

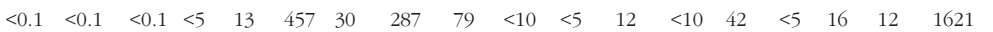
$\begin{array}{llllllllllllllllll}<0.1 & <0.1 & <0.1 & <5 & 8 & 164 & 22 & 511 & 72 & <10 & 7 & 13 & 42 & 76 & <5 & 18 & <10 & 1289\end{array}$

$\begin{array}{llllllllllllllllll}<0.1 & <0.1 & <0.1 & <5 & 10 & 120 & 43 & 607 & 19 & <10 & <5 & <10 & 25 & 163 & <5 & 31 & <10 & 361\end{array}$ $\begin{array}{llllllllllllllllll}<0.1 & <0.1 & <0.1 & <5 & 14 & 52 & 43 & 101 & 82 & <10 & 10 & 11 & 10 & <10 & <5 & 37 & 10 & 662\end{array}$

$\begin{array}{llllllllllllllllll}0.28 & <0.1 & 0.27 & <5 & 5 & 21 & 14 & 329 & <5 & <10 & <5 & <10 & 15 & 749 & <5 & 43 & <10 & 110\end{array}$ $\begin{array}{llllllllllllllllll}<0.1 & <0.1 & <0.1 & <5 & 14 & 249 & 51 & 416 & 55 & <10 & <5 & <10 & 45 & 141 & <5 & 17 & <10 & 1237\end{array}$ $\begin{array}{llllllllllllllllll}<0.1 & <0.1 & <0.1 & <5 & 5 & 437 & 13 & 35 & 94 & <10 & 17 & 18 & 12 & <10 & <5 & <10 & <10 & 255\end{array}$ $\begin{array}{lllllllllllllllll}<0.1 & <0.1 & <0.1 & <5 & 73 & 15495 & 221 & 107 & <10 & 10 & <10 & 10 & <10 & <5 & <10 & 27 & 452\end{array}$

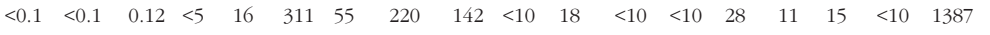
$\begin{array}{llllllllllllllllll}<0.1 & <0.1 & 0.1 & <5 & 14 & 196 & 37 & 256 & 184 & <10 & 9 & 17 & 11 & 20 & <5 & <10 & <10 & 1328\end{array}$ $\begin{array}{llllllllllllllllll}<0.1 & <0.1 & 0.14 & <5 & 12 & 304 & 23 & 282 & 80 & <10 & 8 & 12 & 10 & 12 & <5 & 10 & 10 & 2003\end{array}$ $\begin{array}{llllllllllllllllll}<0.1 & <0.1 & 0.12 & <5 & 13 & 313 & 45 & 285 & 144 & <10 & 9 & 14 & 12 & 60 & <5 & 18 & <10 & 1346\end{array}$

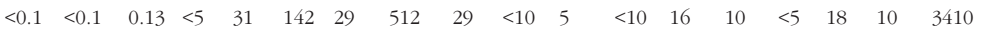

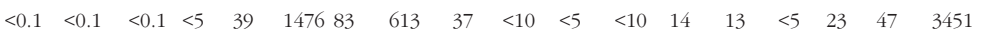

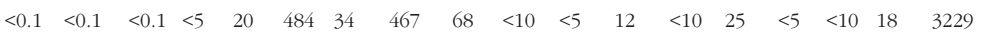

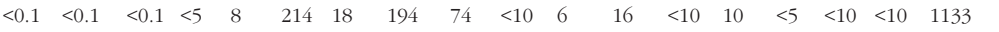
$<0.1<0.1 \quad<0.1<5 \quad 22 \quad 405 \quad 43$ $<0.1<0.1 \quad<0.1<5 \quad 16 \quad 314 \quad 57$ $<0.1<0.1 \quad<0.1<5 \quad 5 \quad 116 \quad 5$ $<0.1<0.1 \quad<0.1<5 \quad 16 \quad 648 \quad 22$ $<0.1<0.1 \quad<0.1<5 \quad 61 \quad 319 \quad 8$ $\begin{array}{lllllll}<0.1 & <0.1 & 0.39 & 7 & 207 & 140 & 19\end{array}$ $\begin{array}{llllllllllllllllll}<0.1 & <0.1 & 0.3 & <5 & 22 & 329 & 8 & 340 & 54 & <10 & 5 & 11 & 11 & 87 & <5 & 24 & 14 & 475\end{array}$

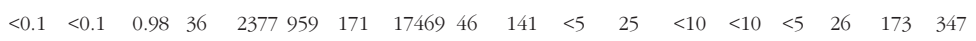
$\begin{array}{llllllllllllllllll}<0.1 & <0.1 & 0.31 & <5 & 82 & 98 & 87 & 7077 & 46 & <10 & <5 & <10 & 15 & 28 & <5 & 18 & 81 & 786\end{array}$ $\begin{array}{llllllllllllllllll}<0.1 & <0.1 & 1.23 & <5 & 675 & <5 & 740 & 27729 & <5 & <10 & <5 & 17 & 11 & <10 & <5 & 37 & 257 & 388\end{array}$

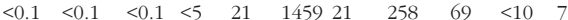

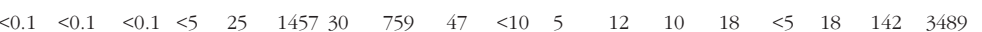

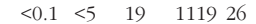

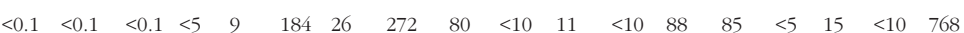
$\begin{array}{llllllllllllllllll}<0.1 & <0.1 & 0.41 & 13 & 36 & 619 & 118 & 68 & 194 & <10 & 31 & 25 & <10 & <10 & <5 & <10 & 13 & 317\end{array}$ $<0.1<0.1 \quad<0.1<5 \quad 25 \quad 266 \quad 58$
$<10 \quad<10 \quad 11$

$\begin{array}{llllllllllll}25 & 10 & <5 & <15 & 6 & <10 & 11 & <10 & 22 & <10 & <10 & <10\end{array}$ $\begin{array}{llllllllllll}57 & 13 & <5 & <15 & 7 & 131 & 42 & 47 & 17 & 12 & <10 & <10\end{array}$ $\begin{array}{llllllllllll}42 & 14 & <5 & <15 & 7 & 15 & 19 & 11 & 30 & <10 & <10 & <10\end{array}$ $\begin{array}{llllllllllll}53 & 12 & <5 & <15 & 8 & 51 & 28 & 26 & 27 & <10 & <10 & 10\end{array}$ $\begin{array}{llllllllllll}82 & 19 & <5 & <15 & <5 & 103 & 62 & 53 & 19 & <10 & <10 & <10\end{array}$ $\begin{array}{llllllllllll}73 & 19 & 18 & <15 & 17 & 45 & 24 & 23 & 19 & <10 & <10 & <10\end{array}$ $\begin{array}{llllllllllll}91 & 17 & <5 & <15 & 5 & 128 & 52 & 67 & 15 & <10 & <10 & 16\end{array}$ $\begin{array}{llllllllllll}55 & 17 & <5 & <15 & 6 & 58 & 34 & 33 & 25 & <10 & <10 & <10\end{array}$ $\begin{array}{llllllllllll}83 & 23 & 7 & <15 & 17 & 50 & 28 & 23 & 18 & <10 & <10 & <10\end{array}$ $\begin{array}{llllllllllll}49 & <10 & <5 & <15 & 7 & 138 & 105 & 46 & 31 & 13 & <10 & 10\end{array}$ $\begin{array}{llllllllllll}75 & <10 & <5 & <15 & 6 & 85 & 58 & 49 & 39 & <10 & <10 & 12\end{array}$ $\begin{array}{llllllllllll}75 & 10 & <5 & <15 & 8 & 10 & 28 & 14 & 23 & <10 & <10 & <10\end{array}$ $\begin{array}{llllllllllll}34 & 13 & <5 & <15 & 6 & 148 & 92 & 63 & 29 & <10 & <10 & 13\end{array}$ $\begin{array}{llllllllllll}54 & 15 & <5 & <15 & 10 & 25 & 52 & 31 & 24 & <10 & <10 & <10\end{array}$ $\begin{array}{llllllllllll}58 & <10 & 6 & <15 & 11 & 37 & 36 & 37 & 29 & <10 & <10 & <10\end{array}$ $\begin{array}{llllllllllll}46 & 14 & <5 & <15 & 9 & 22 & 17 & 13 & 29 & <10 & <10 & <10\end{array}$ $\begin{array}{llllllllllll}67 & 54 & 32 & <15 & 18 & 59 & 34 & 33 & 18 & <10 & <10 & 13\end{array}$ $\begin{array}{llllllllllll}43 & 10 & 12 & <15 & 12 & 13 & 14 & 16 & 28 & <10 & <10 & <10\end{array}$ $\begin{array}{llllllllllll}85 & 13 & <5 & <15 & 8 & 65 & 35 & 45 & 18 & <10 & <10 & <10\end{array}$

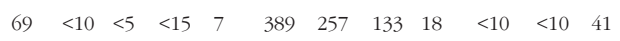
$\begin{array}{llllllllllll}116 & 18 & <5 & <15 & 19 & 124 & 59 & 72 & <10 & <10 & <10 & 15\end{array}$ $\begin{array}{llllllllllll}80 & 22 & 26 & <15 & 23 & 107 & 59 & 39 & 10 & <10 & <10 & 13\end{array}$ $\begin{array}{llllllllllll}44 & 13 & <5 & <15 & 5 & 102 & 65 & 42 & 27 & <10 & <10 & <10\end{array}$ $\begin{array}{llllllllllll}126 & 21 & 51 & <15 & 72 & 59 & 43 & 27 & <10 & <10 & <10 & <10\end{array}$ $\begin{array}{llllllllllll}103 & 35 & 54 & <15 & 54 & <10 & <10 & <10 & 10 & <10 & 14 & 10\end{array}$ $\begin{array}{lllllllllllllll}<10 & <10 & 14 & 112 & <10 & 5 & <15 & 8 & 84 & 34 & 48 & 14 & 18 & <10 & 12\end{array}$ $\begin{array}{lllllllllllllll}<10 & <10 & 11 & 36 & <10 & <5 & <15 & 7 & 29 & 23 & 15 & 23 & <10 & <10 & <10\end{array}$ $\begin{array}{lllllllllllllll}<10 & <10 & 11 & 22 & 11 & <5 & <15 & 6 & 69 & 36 & 24 & 26 & <10 & <10 & <10\end{array}$ $\begin{array}{lllllllllllllll}<10 & <10 & <10 & 47 & <10 & <5 & <15 & 5 & 94 & 54 & 45 & 21 & <10 & <10 & <10\end{array}$ $\begin{array}{lllllllllllllll}<10 & <10 & 18 & 62 & 12 & <5 & <15 & 9 & 25 & 18 & 19 & 11 & <10 & <10 & <10\end{array}$ $\begin{array}{lllllllllllllll}<10 & <10 & 13 & 62 & 13 & 8 & <15 & 12 & 53 & 22 & 23 & 20 & <10 & <10 & <10\end{array}$ $\begin{array}{lllllllllllllll}<10 & <10 & 15 & 141 & 22 & <5 & <15 & 81 & <10 & <10 & <10 & <10 & <10 & 11 & <10\end{array}$ $\begin{array}{lllllllllllllll}<10 & <10 & 18 & 108 & 16 & 6 & <15 & 20 & 106 & 44 & 54 & 26 & <10 & <10 & 15\end{array}$ $\begin{array}{lllllllllllllll}<10 & <10 & 11 & 31 & <10 & <5 & <15 & 5 & 144 & 94 & 68 & 23 & <10 & <10 & 17\end{array}$ $\begin{array}{lllllllllllllll}<10 & <10 & 13 & 51 & <10 & <5 & <15 & 7 & 32 & <10 & 13 & <10 & <10 & <10 & <10\end{array}$ $\begin{array}{lllllllllllllll}<10 & <10 & 15 & 66 & <10 & <5 & <15 & 6 & 111 & 63 & 51 & 23 & <10 & <10 & 12\end{array}$ $\begin{array}{lllllllllllllll}<10 & <10 & 10 & 46 & <10 & 5 & <15 & <5 & 70 & 53 & 26 & 32 & <10 & <10 & 10\end{array}$ $\begin{array}{lllllllllllllll}<10 & <10 & 14 & 46 & <10 & <5 & <15 & <5 & 163 & 89 & 55 & 31 & 11 & <10 & 15\end{array}$ $\begin{array}{lllllllllllllll}<10 & <10 & 16 & 81 & <10 & 7 & <15 & 12 & 94 & 57 & 46 & 30 & <10 & <10 & 10\end{array}$ $\begin{array}{lllllllllllllll}<10 & <10 & 21 & 116 & <10 & <5 & <15 & 10 & 65 & 34 & 20 & 19 & <10 & <10 & <10\end{array}$ $\begin{array}{lllllllllllllll}<10 & <10 & 21 & 170 & <10 & <5 & <15 & 9 & 161 & 53 & 84 & 15 & 15 & <10 & 13\end{array}$ $\begin{array}{lllllllllllllll}<10 & <10 & 17 & 75 & <10 & <5 & <15 & <5 & 83 & 43 & 42 & 28 & 11 & <10 & 10\end{array}$ $\begin{array}{lllllllllllllll}<10 & <10 & 10 & 40 & <10 & <5 & <15 & <5 & 208 & 141 & 67 & 33 & <10 & <10 & 25\end{array}$ $\begin{array}{lllllllllllllll}<10 & <10 & 17 & 69 & <10 & <5 & <15 & <5 & 88 & 48 & 42 & 29 & <10 & <10 & 10\end{array}$ $\begin{array}{lllllllllllllll}<10 & <10 & 21 & 153 & 13 & <5 & <15 & 10 & 89 & 48 & 45 & 17 & <10 & <10 & 10\end{array}$ $\begin{array}{lllllllllllllll}<10 & <10 & <10 & 9 & <10 & <5 & <15 & 6 & <10 & <10 & <10 & 34 & <10 & <10 & <10\end{array}$ $\begin{array}{lllllllllllllll}<10 & <10 & 14 & 30 & 10 & <5 & <15 & 6 & <10 & <10 & <10 & 28 & <10 & <10 & <10\end{array}$ $\begin{array}{lllllllllllllll}<10 & <10 & 16 & 40 & <10 & <5 & <15 & <5 & 45 & 23 & 24 & 27 & <10 & <10 & <10\end{array}$ $\begin{array}{lllllllllllllll}<10 & <10 & <10 & 86 & <10 & <5 & <15 & 12 & 193 & 77 & 72 & 18 & <10 & <10 & 17\end{array}$ $\begin{array}{lllllllllllllll}<10 & 84 & 13 & 116 & <10 & <5 & <15 & 15 & 251 & 62 & 116 & <10 & <10 & 10 & 28\end{array}$ $\begin{array}{lllllllllllllll}<10 & 94 & <10 & 43 & <10 & <5 & <15 & 26 & 104 & 52 & 62 & <10 & <10 & 13 & 20\end{array}$ $\begin{array}{lllllllllllllll}<10 & 12 & <10 & 103 & 31 & <5 & <15 & <5 & 1195 & 249 & 570 & <10 & 15 & 166 & 135\end{array}$ $\begin{array}{lllllllllllllll}<10 & 38 & 10 & 30 & 11 & <5 & <15 & 10 & 695 & 252 & 297 & <10 & <10 & <10 & 82\end{array}$ $\begin{array}{lllllllllllllll}<10 & 21 & <10 & 85 & 38 & 26 & 59 & <5 & 5330 & 1419 & 2020<10 & 13 & 49 & 560\end{array}$ $\begin{array}{lllllllllllllll}<10 & <10 & 18 & 79 & <10 & <5 & <15 & 7 & 80 & 29 & 36 & <10 & <10 & 11 & 10\end{array}$ $\begin{array}{lllllllllllllll}<10 & <10 & 18 & 82 & 11 & 8 & <15 & 13 & 45 & 45 & 22 & 19 & <10 & <10 & <10\end{array}$ $\begin{array}{lllllllllllllll}<10 & <10 & 24 & 112 & 15 & <5 & <15 & 10 & 93 & 34 & 52 & <10 & 17 & 13 & 10\end{array}$ $\begin{array}{lllllllllllllll}<10 & <10 & 18 & 112 & 14 & <5 & <15 & 14 & 213 & 93 & 101 & <10 & <10 & 12 & 26\end{array}$ $\begin{array}{lllllllllllllll}<10 & <10 & 19 & 94 & 18 & <5 & <15 & 10 & 81 & 33 & 31 & <10 & 10 & 16 & <10\end{array}$ $\begin{array}{lllllllllllllll}<10 & <10 & 15 & 87 & 13 & <5 & <15 & 10 & 80 & 31 & 39 & <10 & <10 & <10 & 14\end{array}$ $\begin{array}{lllllllllllllll}<10 & <10 & 15 & 71 & 24 & 16 & <15 & 13 & 55 & 25 & 21 & 28 & <10 & <10 & <10\end{array}$ $\begin{array}{lllllllllllllll}<10 & <10 & 17 & 119 & <10 & 9 & <15 & 5 & 672 & 344 & 277 & 27 & <10 & <10 & 73\end{array}$ \begin{tabular}{lllllllllllllll}
$<10$ & $<10$ & 11 & 75 & $<10$ & 7 & $<15$ & 8 & 81 & 44 & 40 & 29 & 11 & $<10$ & $<10$ \\
\hline
\end{tabular} 


\begin{tabular}{|c|c|c|c|c|c|c|c|c|c|c|c|c|c|c|c|c|c|c|}
\hline Sample & UTM, E & UTM, $\mathbf{N}$ & Zone & Field name & Tectonic Unit & $\mathrm{SiO}_{2}$ & $\mathrm{TiO}_{2}$ & $\mathbf{A l}_{2} \mathrm{O}_{3}$ & $\mathrm{Fe}_{2} \mathrm{O}_{3}$ & FeOt & MgO & $\mathrm{CaO}$ & $\mathrm{Na}_{2} \mathrm{O}$ & $\mathbf{K}_{2} \mathrm{O}$ & Mno & $\mathbf{P}_{2} \mathrm{O}_{5}$ & Gl.tap & sum \\
\hline 33593 & 241969 & 8305992 & 37 & Granitic orthogneiss & Unango Complex & 74.19 & 0.25 & 12.88 & 1.25 & 1.13 & 0.23 & 1.02 & 3.05 & 5.31 & 0.02 & 0.05 & 0.21 & 98.47 \\
\hline 33592 & 248021 & 8309992 & 37 & Granitic orthogneiss & Unango Complex & 65.86 & 0.97 & 13.68 & 6.23 & 5.61 & 0.83 & 2.35 & 3.27 & 4.90 & 0.08 & 0.26 & 0.57 & 98.99 \\
\hline 33586 & 250368 & 8303631 & 37 & Felsic/intermediate granulites/charnockites & Unango Complex & 75.01 & 0.28 & 11.99 & 2.84 & 2.56 & 0.08 & 0.85 & 2.33 & 5.97 & 0.03 & 0.05 & 0.13 & 99.55 \\
\hline 33556 & 262351 & 8317840 & 37 & Pan-African granites & Unango Complex & 69.30 & 0.50 & 14.11 & 3.26 & 2.93 & 0.48 & 1.81 & 2.70 & 5.78 & 0.02 & 0.11 & 0.81 & 98.89 \\
\hline 34288 & 742064 & 8527300 & 37 & Quartz monzonite & Unango Complex & 64.50 & 0.94 & 15.60 & 4.60 & 4.14 & 1.28 & 3.18 & 4.26 & 3.51 & 0.08 & 0.27 & 0.22 & 98.45 \\
\hline 22792 & 218416 & 8494372 & 37 & Granitic gneiss & Marrupa Complex & 74.38 & 0.19 & 12.66 & 1.57 & 1.41 & 0.26 & 1.13 & 3.61 & 4.01 & 0.06 & 0.06 & 0.15 & 98.08 \\
\hline 22773 & 231051 & 8512990 & 37 & Tonalitic gneiss & Marrupa Complex & 75.17 & 0.17 & 13.64 & 1.41 & 1.27 & 0.26 & 1.03 & 4.31 & 3.45 & 0.05 & 0.09 & 0.28 & 99.88 \\
\hline 37241 & 231954 & 8684996 & 37 & Dioritic gneiss & Marrupa Complex & 61.60 & 1.28 & 15.56 & 6.42 & 5.78 & 1.65 & 2.96 & 4.48 & 3.77 & 0.15 & 0.51 & 0.30 & 98.69 \\
\hline 37242 & 231954 & 8684996 & 37 & Granitic orthogneiss & Marrupa Complex & 69.83 & 0.49 & 14.58 & 3.20 & 2.88 & 0.62 & 1.57 & 4.14 & 3.93 & 0.04 & 0.16 & 0.47 & 99.03 \\
\hline 34292 & 244835 & 8480275 & 37 & Granitic gneiss & Marrupa Complex & 69.13 & 0.31 & 15.70 & 2.35 & 2.12 & 0.94 & 1.79 & 4.57 & 3.57 & 0.07 & 0.10 & 0.34 & 98.86 \\
\hline 34293 & 246159 & 8479490 & 37 & Granitic gneiss & Marrupa Complex & 70.92 & 0.23 & 15.01 & 1.88 & 1.69 & 0.63 & 2.09 & 4.94 & 1.97 & 0.06 & 0.10 & 0.22 & 98.04 \\
\hline 34287 & 247880 & 8469118 & 37 & Granitic gneiss & Marrupa Complex & 75.42 & 0.26 & 12.66 & 1.37 & 1.23 & 0.28 & 0.95 & 3.36 & 4.70 & 0.06 & 0.07 & 0.12 & 99.26 \\
\hline 33503 & 250690 & 8404299 & 37 & Gneissic granite with mafic dykes. & Marrupa Complex & 73.64 & 0.31 & 12.62 & 1.44 & 1.30 & 0.31 & 0.93 & 2.83 & 5.68 & 0.02 & 0.05 & 0.22 & 98.05 \\
\hline 34297 & 251050 & 8472510 & 37 & Granodi gneiss & Marrupa Complex & 73.84 & 0.43 & 12.68 & 2.36 & 2.12 & 0.81 & 1.05 & 3.54 & 3.89 & 0.07 & 0.10 & 0.25 & 99.03 \\
\hline 33479 & 259647 & 8373067 & 37 & Syenite & Marrupa Complex & 61.43 & 0.47 & 17.09 & 4.58 & 4.12 & 1.26 & 2.47 & 6.78 & 3.39 & 0.19 & 0.17 & 0.30 & 98.13 \\
\hline 34274 & 262406 & 8476174 & 37 & Granitic gneiss & Marrupa Complex & 70.52 & 0.32 & 15.22 & 1.77 & 1.59 & 0.31 & 1.08 & 3.83 & 5.47 & 0.03 & 0.05 & 0.26 & 98.86 \\
\hline 33502 & 269824 & 8440454 & 37 & Granitic gneiss & Marrupa Complex & 72.11 & 0.30 & 13.97 & 1.79 & 1.61 & 0.38 & 1.57 & 3.40 & 4.88 & 0.05 & 0.09 & 0.51 & 99.03 \\
\hline 37238 & 270155 & 8700622 & 37 & Quartzofeldspathic gneiss & Marrupa Complex & 69.51 & 0.26 & 16.52 & 2.06 & 1.85 & 0.50 & 2.65 & 4.75 & 2.42 & 0.05 & 0.08 & 0.30 & 99.09 \\
\hline 34282 & 271555 & 8510006 & 37 & Granitic gneiss & Marrupa Complex & 74.83 & 0.28 & 12.69 & 1.49 & 1.34 & 0.30 & 0.86 & 3.15 & 5.08 & 0.05 & 0.07 & 0.23 & 99.03 \\
\hline 34284 & 272608 & 8508010 & 37 & Granodi gneiss & Marrupa Complex & 68.93 & 0.69 & 14.40 & 3.82 & 3.44 & 0.81 & 1.88 & 3.68 & 4.14 & 0.07 & 0.19 & 0.35 & 98.95 \\
\hline 31839 & 274161 & 8647892 & 37 & Granitic gneiss & Marrupa Complex & 72.96 & 0.25 & 13.85 & 2.37 & 2.13 & 0.38 & 1.23 & 3.63 & 4.37 & 0.04 & 0.07 & 0.24 & 99.39 \\
\hline 33508 & 274416 & 8423162 & 37 & Gneissic mangerite & Marrupa Complex & 67.22 & 0.78 & 14.88 & 3.62 & 3.26 & 0.77 & 1.42 & 5.21 & 4.20 & 0.16 & 0.24 & 0.13 & 98.64 \\
\hline 37236 & 276590 & 8677408 & 37 & Quartz leuco diorite & Marrupa Complex & 68.84 & 0.46 & 14.92 & 2.77 & 2.49 & 1.02 & 2.46 & 3.60 & 4.14 & 0.07 & 0.12 & 0.21 & 98.62 \\
\hline 33498 & 283087 & 8435408 & 37 & Monzonitic granite & Marrupa Complex & 78.92 & 0.22 & 11.11 & 1.00 & 0.90 & 0.05 & 0.37 & 2.90 & 4.71 & $<0.01$ & 0.02 & 0.13 & 99.43 \\
\hline 26813 & 284330 & 8425956 & 37 & Quartz-rich granitic gneiss (602) & Marrupa Complex & 73.65 & 0.28 & 13.58 & 2.13 & 1.92 & 0.70 & 2.35 & 4.53 & 1.10 & 0.04 & 0.09 & 0.20 & 98.65 \\
\hline 33345 & 286120 & 8479996 & 37 & Granitic gneiss & Marrupa Complex & 75.45 & 0.11 & 12.23 & 1.68 & 1.51 & 0.02 & 0.52 & 3.20 & 4.96 & $<0.01$ & 0.03 & 0.20 & 98.42 \\
\hline 33251 & 306339 & 8461572 & 37 & granitic gneiss & Marrupa Complex & 74.12 & 0.14 & 14.14 & 1.21 & 1.09 & 0.27 & 1.70 & 4.45 & 2.55 & 0.04 & 0.03 & 0.22 & 98.87 \\
\hline 38410 & 306368 & 8606984 & 37 & Plagioclase gneiss & Marrupa Complex & 67.95 & 0.42 & 14.93 & 4.73 & 4.26 & 0.61 & 2.97 & 3.98 & 2.38 & 0.13 & 0.11 & 0.20 & 98.40 \\
\hline 33253 & 308221 & 8523726 & 37 & granitic gneiss & Marrupa Complex & 67.57 & 0.54 & 15.46 & 2.84 & 2.56 & 0.59 & 2.06 & 3.72 & 4.88 & 0.06 & 0.14 & 0.29 & 98.15 \\
\hline 33428 & 319769 & 8498526 & 37 & Tonalitic orthogneiss & Marrupa Complex & 70.25 & 0.27 & 14.27 & 2.70 & 2.43 & 0.36 & 1.46 & 2.86 & 5.24 & 0.06 & 0.10 & 0.77 & 98.35 \\
\hline 37273 & 322187 & 8618362 & 37 & Granodioritic gneiss & Marrupa Complex & 69.01 & 0.51 & 14.74 & 3.35 & 3.02 & 1.31 & 2.79 & 4.72 & 2.08 & 0.08 & 0.15 & 0.48 & 99.22 \\
\hline 37274 & 322234 & 8618324 & 37 & Microgranodioritic dyke & Marrupa Complex & 69.65 & 0.45 & 14.66 & 2.38 & 2.14 & 0.44 & 1.17 & 3.84 & 5.33 & 0.02 & 0.11 & 0.22 & 98.26 \\
\hline 37229 & 324095 & 8706898 & 37 & Intermediate orthogneiss & Marrupa Complex & 56.34 & 0.65 & 9.00 & 6.62 & 5.96 & 6.42 & 15.38 & 1.54 & 2.09 & 0.16 & 0.23 & 0.78 & 99.21 \\
\hline 33405 & 326441 & 8518115 & 37 & Granitic Gneiss & Marrupa Complex & 71.49 & 0.30 & 14.44 & 1.76 & 1.58 & 0.38 & 1.38 & 3.59 & 5.32 & 0.05 & 0.09 & 0.22 & 99.01 \\
\hline 37227 & 327696 & 8704212 & 37 & LEUCOCRATIC GNEISS & Marrupa Complex & 67.93 & 0.32 & 15.64 & 3.64 & 3.28 & 1.44 & 3.85 & 4.54 & 1.31 & 0.08 & 0.10 & 0.59 & 99.45 \\
\hline 26831 & 328522 & 8423696 & 37 & Ultramafics (harzburgite?) (701) & Marrupa Complex & 47.32 & 0.56 & 6.20 & 10.11 & 9.10 & 17.55 & 15.77 & 0.53 & 0.14 & 0.18 & 0.05 & 0.30 & 98.70 \\
\hline 26829 & 329549 & 8422945 & 37 & Ultramafics (harzburgite?) (701) & Marrupa Complex & 48.99 & 0.59 & 6.29 & 9.00 & 8.10 & 16.10 & 15.51 & 0.99 & 0.34 & 0.18 & 0.07 & 0.36 & 98.42 \\
\hline 37235 & 329570 & 8696308 & 37 & Charnockite & Marrupa Complex & 56.34 & 0.90 & 16.66 & 7.65 & 6.89 & 4.03 & 6.41 & 3.57 & 2.10 & 0.14 & 0.37 & 0.27 & 98.45 \\
\hline 33341 & 329690 & 8534768 & 37 & Tonalitic gneiss & Marrupa Complex & 71.91 & 0.17 & 15.31 & 1.68 & 1.51 & 0.39 & 2.81 & 4.63 & 1.36 & 0.04 & 0.08 & 0.26 & 98.64 \\
\hline 33252 & 335562 & 8537364 & 37 & granitic gneiss & Marrupa Complex & 73.00 & 0.14 & 14.78 & 1.37 & 1.23 & 0.40 & 2.38 & 4.34 & 2.11 & 0.05 & 0.08 & 0.23 & 98.87 \\
\hline 37239 & 337182 & 8600746 & 37 & Amphibolite & Marrupa Complex & 47.91 & 2.55 & 13.07 & 14.92 & 13.43 & 5.84 & 9.83 & 2.79 & 0.87 & 0.25 & 0.33 & 0.16 & 98.51 \\
\hline 33408 & 340035 & 8563232 & 37 & Granitic gneiss & Marrupa Complex & 72.13 & 0.13 & 14.47 & 1.37 & 1.23 & 0.18 & 1.01 & 3.88 & 5.17 & 0.03 & 0.03 & 0.39 & 98.80 \\
\hline 26826 & 340193 & 8417284 & 37 & Economic, calcsilicate & Marrupa Complex & 66.77 & 0.62 & 14.60 & 2.48 & 2.23 & 2.01 & 3.91 & 7.66 & 0.64 & 0.08 & 0.02 & 0.18 & 98.97 \\
\hline 26827 & 340193 & 8417284 & 37 & Economic, sulphidic & Marrupa Complex & 69.23 & 0.69 & 13.67 & 3.91 & 3.52 & $<0.01$ & 0.94 & 6.96 & 0.52 & $<0.01$ & 0.05 & 3.05 & 98.96 \\
\hline 26828 & 340193 & 8417284 & 37 & Economic. gossan & Marrupa Complex & 17.83 & 0.34 & 3.70 & 65.22 & 58.70 & 1.26 & 0.96 & 1.36 & 0.11 & 0.08 & 0.04 & 3.43 & 94.33 \\
\hline 37268 & 344765 & 8624470 & 37 & Granodioritic gneiss & Marrupa Complex & 63.22 & 0.76 & 16.06 & 4.76 & 4.28 & 2.41 & 4.55 & 3.89 & 2.61 & 0.07 & 0.14 & 0.36 & 98.83 \\
\hline 33202 & 347437 & 8551266 & 37 & Granodioritic(tonalitic) migmatitic gneiss & Marrupa Complex & 71.31 & 0.36 & 14.42 & 2.72 & 2.45 & 0.55 & 2.05 & 4.09 & 2.90 & 0.08 & 0.10 & 0.23 & 98.80 \\
\hline 26821 & 351155 & 8390767 & 37 & Gneissic bt-granite (602) & Marrupa Complex & 71.65 & 0.25 & 14.09 & 1.86 & 1.67 & 0.32 & 1.32 & 3.71 & 5.17 & 0.01 & 0.10 & 0.25 & 98.73 \\
\hline 33205 & 353422 & 8635806 & 37 & Granite & Marrupa Complex & 75.36 & 0.19 & 11.72 & 2.56 & 2.30 & 0.05 & 0.87 & 3.33 & 4.08 & 0.03 & 0.03 & 0.18 & 98.42 \\
\hline 37226 & 353463 & 8649630 & 37 & Migmatised granitic orthogneiss & Marrupa Complex & 76.10 & 0.13 & 11.73 & 1.40 & 1.26 & 0.11 & 0.61 & 2.94 & 4.81 & 0.03 & 0.06 & 0.28 & 98.20 \\
\hline 33207 & 353877 & 8638948 & 37 & Quartz dioritic gneiss & Marrupa Complex & 59.29 & 1.52 & 15.16 & 7.88 & 7.09 & 2.32 & 4.44 & 4.01 & 2.90 & 0.14 & 0.37 & 0.25 & 98.28 \\
\hline 33206 & 353958 & 8637452 & 37 & Granitic mylonite & Marrupa Complex & 69.77 & 0.52 & 14.97 & 2.82 & 2.54 & 0.64 & 2.19 & 4.32 & 3.03 & 0.04 & 0.13 & 0.41 & 98.83 \\
\hline 33204 & 354416 & 8620838 & 37 & Tonalitic gneiss & Marrupa Complex & 65.99 & 0.39 & 17.79 & 2.44 & 2.20 & 0.87 & 3.80 & 5.27 & 1.70 & 0.04 & 0.11 & 0.31 & 98.71 \\
\hline 33343 & 354793 & 8542848 & 37 & Granitic gneiss & Marrupa Complex & 72.41 & 0.28 & 13.71 & 1.48 & 1.33 & 0.30 & 1.07 & 3.72 & 4.61 & 0.02 & 0.07 & 0.40 & 98.07 \\
\hline 33407 & 355376 & 8513482 & 37 & Granodioritic gneiss & Marrupa Complex & 67.87 & 0.46 & 16.22 & 2.63 & 2.37 & 1.00 & 2.67 & 4.74 & 2.63 & 0.04 & 0.12 & 0.39 & 98.77 \\
\hline 33203 & 357122 & 8569532 & 37 & Granitic gneiss & Marrupa Complex & 75.82 & 0.26 & 11.96 & 1.52 & 1.37 & 0.09 & 0.45 & 2.68 & 5.83 & 0.03 & 0.03 & 0.18 & 98.85 \\
\hline 37276 & 357205 & 8652666 & 37 & Granodioritic migmatite & Marrupa Complex & 57.49 & 1.23 & 15.31 & 4.96 & 4.46 & 1.99 & 5.03 & 3.12 & 6.41 & 0.09 & 1.13 & 0.29 & 97.05 \\
\hline 33406 & 358388 & 8514739 & 37 & Migmatite & Marrupa Complex & 73.35 & 0.17 & 13.39 & 1.96 & 1.76 & 0.33 & 1.00 & 2.92 & 5.04 & 0.04 & 0.05 & 0.35 & 98.59 \\
\hline 33208 & 358663 & 8624950 & 37 & Granitic gneiss & Marrupa Complex & 65.27 & 0.59 & 15.93 & 3.95 & 3.56 & 0.73 & 2.36 & 3.70 & 5.08 & 0.07 & 0.15 & 0.27 & 98.10 \\
\hline 37277 & 359440 & 8651292 & 37 & Metagabbro dyke within granitic gneiss & Marrupa Complex & 37.34 & 2.02 & 21.59 & 12.69 & 11.42 & 1.04 & 21.90 & 0.20 & 0.05 & 0.09 & 0.39 & 0.78 & 98.09 \\
\hline 37251 & 360501 & 8661657 & 37 & mylonitic migmatitic mafic gneiss & Marrupa Complex & 62.46 & 0.79 & 15.83 & 5.89 & 5.30 & 2.33 & 4.06 & 3.51 & 2.74 & 0.09 & 0.19 & 0.63 & 98.53 \\
\hline 38401 & 364168 & 8607288 & 37 & Tonalitic gneiss & Marrupa Complex & 65.90 & 0.55 & 15.64 & 3.28 & 2.95 & 1.64 & 3.48 & 3.96 & 3.12 & 0.05 & 0.11 & 0.26 & 97.99 \\
\hline 33209 & 369213 & 8640838 & 37 & Granitic gneiss & Marrupa Complex & 72.96 & 0.21 & 14.90 & 1.42 & 1.28 & 0.31 & 1.66 & 4.26 & 3.83 & 0.02 & 0.06 & 0.29 & 99.91 \\
\hline 37253 & 372536 & 8671487 & 37 & Quartzite & Marrupa Complex & 85.51 & 0.28 & 10.41 & 0.08 & 0.07 & 0.09 & 0.08 & 0.14 & 0.08 & $<0.01$ & 0.01 & 0.14 & 96.82 \\
\hline 37254 & 373985 & 8671974 & 37 & Quartzofeldspathic gneiss & Marrupa Complex & 73.01 & 0.28 & 12.79 & 2.91 & 2.62 & 0.64 & 1.57 & 3.41 & 3.76 & 0.07 & 0.06 & 0.57 & 99.07 \\
\hline 37240 & 374137 & 8749722 & 37 & Migm granodioritic orthogneiss & Marrupa Complex & 71.09 & 0.52 & 13.68 & 2.48 & 2.23 & 0.82 & 1.67 & 3.38 & 4.25 & 0.06 & 0.14 & 0.29 & 98.39 \\
\hline 38406 & 380540 & 8516830 & 37 & Tonalitic gneiss & Marrupa Complex & 64.96 & 1.14 & 14.37 & 6.04 & 5.44 & 1.70 & 3.89 & 3.48 & 3.11 & 0.11 & 0.27 & 0.12 & 99.18 \\
\hline 37255 & 381432 & 8667529 & 37 & Stromatic grey gneiss & Marrupa Complex & 59.90 & 0.72 & 16.51 & 6.47 & 5.82 & 3.38 & 6.00 & 3.59 & 1.78 & 0.10 & 0.16 & 0.56 & 99.17 \\
\hline 38405 & 395173 & 8647016 & 37 & Amphibolitic gneiss & Marrupa Complex & 49.16 & 0.44 & 9.15 & 9.27 & 8.34 & 6.39 & 21.21 & 1.33 & 0.27 & 0.63 & 0.23 & 0.41 & 98.48 \\
\hline
\end{tabular}




\begin{tabular}{lllllllllllllllllllllllllllllllllllll}
$\mathbf{S}$ & $\mathbf{C l}$ & $\mathbf{F}$ & $\mathbf{M o}$ & $\mathbf{N b}$ & $\mathbf{Z r}$ & $\mathbf{Y}$ & $\mathbf{S r}$ & $\mathbf{R b}$ & $\mathbf{U}$ & $\mathbf{T h}$ & $\mathbf{P b}$ & $\mathbf{C r}$ & $\mathbf{V}$ & $\mathbf{A s}$ & $\mathbf{S c}$ & $\mathbf{H f}$ & $\mathbf{B a}$ & $\mathbf{S b}$ & $\mathbf{S n}$ & $\mathbf{G a}$ & $\mathbf{Z n}$ & $\mathbf{C u}$ & $\mathbf{N i}$ & $\mathbf{Y b}$ & $\mathbf{C o}$ & $\mathbf{C e}$ & $\mathbf{L a}$ & $\mathbf{N d}$ & $\mathbf{w}$ & $\mathbf{C s}$ & $\mathbf{T a}$ & $\mathbf{P r}$ \\
\hline 001 & $<01$ & $<0.1$ & $<5$ & 6 & 136 & $<5$ & 63 & 118 & $<10$ & 15 & 16 & $<10$ & 16 & $<5$ & $<10$ & $<10$ & 535 & $<10$ & $<10$ & $<10$ & 20 & 10 & $<5$ & $<15$ & 7 & 30 & 30 & $<10$ & & $<10$ & $<10$ & $<10$
\end{tabular}

$<0.1<0.1 \quad 0.13<5 \quad 24 \quad 542 \quad 49 \quad 318 \quad 127<10 \quad 9$

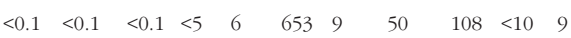
$\begin{array}{lllllllllllllllllllllll}<0.1 & <0.1 & <0.1 & <5 & 12 & 400 & 28 & 305 & 167 & <10 & 54 & 22 & 20 & 26 & <5 & <10 & 30 & 1143 & <10 & <10 & 15\end{array}$ $\begin{array}{lllllllllllllllllllll}<0.1 & <0.1 & 0.23 & <5 & 9 & 273 & 29 & 374 & 68 & <10 & 8 & 15 & <10 & 65 & <5 & 13 & <10 & 1029 & <10 & <10 & 10\end{array}$ $\begin{array}{llllllllllllllllll}<0.1 & <0.1 & <0.1 & <5 & 13 & 112 & 21 & 125 & 155 & <10 & 16 & 12 & 20 & 17 & <5 & <10 & <10 & 762\end{array}$

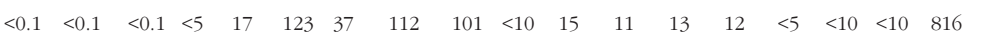
$<0.1<0.1 \quad<0.1<5 \quad 17 \quad 437 \quad 49 \quad 374 \quad 94 \quad<10 \quad 5$

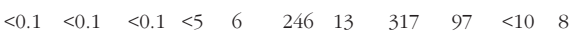

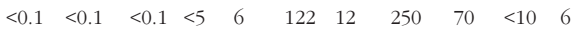
$<0.1<0.1 \quad<0.1 \quad<514 \quad 119 \quad 13 \quad 297 \quad 53 \quad<10 \quad 7$

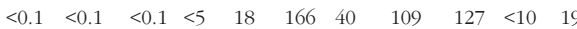

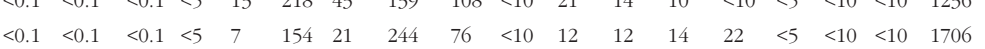

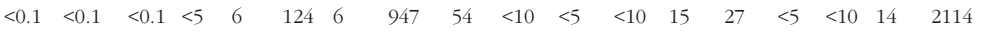
$\begin{array}{llllllllllllllllll}<.1 & <0.1 & <0.1 & <5 & 16 & 169 & 36 & 93 & 183 & <10 & 24 & 13 & 10 & 13 & <5 & <10 & <10 & 640\end{array}$

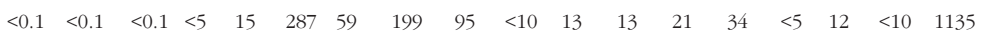

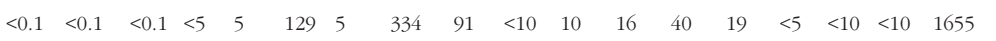

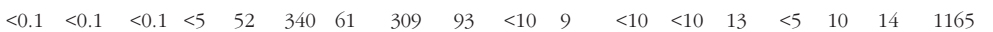
$\begin{array}{llllllllllllllllll}<0.1 & <0.1 & <0.1 & <5 & 8 & 127 & 19 & 331 & 110 & <10 & 7 & 15 & <10 & 39 & <5 & <10 & <10 & 1061\end{array}$

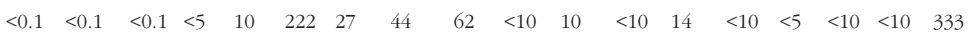

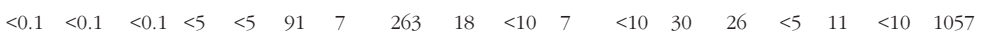
$\begin{array}{llllllllllllllllll}<0.1 & <0.1 & <0.1 & <5 & 9 & 217 & 16 & 99 & 169 & <10 & 18 & 13 & 10 & <10 & <5 & <10 & <10 & 912\end{array}$ $\begin{array}{llllllllllllllllll}<0.1 & <0.1 & <0.1 & <5 & <5 & 80 & 9 & 310 & 50 & <10 & 6 & <10 & 23 & 10 & <5 & <10 & <10 & 908\end{array}$ $\begin{array}{llllllllllllllllll}<0.1 & <0.1 & <0.1 & <5 & 8 & 314 & 33 & 386 & 39 & <10 & <5 & <10 & 38 & 21 & <5 & 18 & 12 & 1388\end{array}$ $\begin{array}{llllllllllllllllll}<0.1 & <0.1 & <0.1 & <5 & 12 & 319 & 42 & 244 & 113 & <10 & 15 & 15 & 18 & 32 & <5 & <10 & <10 & 2193\end{array}$ $\begin{array}{llllllllllllllllll}<0.1 & <0.1 & <0.1 & <5 & <5 & 228 & 7 & 497 & 103 & <10 & 34 & 21 & 14 & 21 & <5 & <10 & <10 & 3868\end{array}$ $\begin{array}{llllllllllllllllll}<0.1 & <0.1 & <0.1 & <5 & 9 & 171 & 38 & 371 & 48 & <10 & 11 & 16 & 21 & 47 & <5 & 17 & <10 & 883\end{array}$ $\begin{array}{llllllllllllllllll}<0.1 & <0.1 & <0.1 & <5 & 10 & 361 & 15 & 597 & 113 & <10 & 39 & 29 & 12 & 17 & <5 & <10 & <10 & 2888\end{array}$

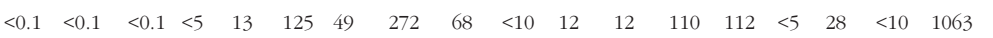

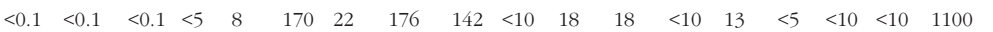
$\begin{array}{llllllllllllllllll}<0.1 & <0.1 & <0.1 & <5 & 5 & 74 & 13 & 338 & 19 & <10 & 7 & <10 & 16 & 48 & <5 & 16 & <10 & 389\end{array}$ $\begin{array}{llllllllllllllllll}<0.1 & <0.1 & <0.1 & <5 & <5 & 33 & 17 & 108 & 5 & <10 & <5 & <10 & 1891 & 243 & 5 & 61 & <10 & 249\end{array}$ $\begin{array}{llllllllllllllllll}<0.1 & <0.1 & <0.1 & <5 & 5 & 59 & 17 & 172 & 8 & <10 & 5 & 13 & 2173 & 188 & <5 & 62 & <10 & 204\end{array}$

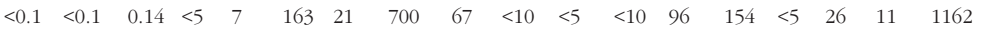

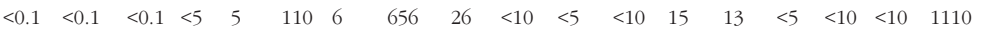
$<0.1<0.1<0.1<5 \quad<5 \quad 93 \quad 5$ $<0.1<0.1 \quad 0.1 \quad<5 \quad 8 \quad 184 \quad 57$ $<0.1<0.1 \quad<0.1<5 \quad 18 \quad 131 \quad 21$ $<0.1<0.1 \quad<0.1<5 \quad 15 \quad 457 \quad 74$ $1.85<0.1<0.1<5 \quad 12 \quad 225 \quad 36 \quad 89$ $\begin{array}{llllllll}0.22 & <0.1 & 0.38 & 11 & 7 & 91 & 8 & 36\end{array}$ $<0.1<0.1 \quad<0.1<5 \quad 6 \quad 164 \quad 21$ $<0.1<0.1 \quad<0.1<5 \quad 6 \quad 143 \quad 19$ $<0.1<0.1<0.1<5 \quad 8 \quad 146 \quad 13$ $<0.1<0.1 \quad<0.1<5 \quad<5 \quad 272 \quad 8$ $<0.1<0.1 \quad<0.1<5 \quad 11 \quad 109 \quad 47$ $<0.1<0.1 \quad 0.24<5 \quad 17 \quad 390 \quad 62$ $<0.1<0.1 \quad<0.1<5 \quad 7 \quad 190 \quad 18$ $<0.1<0.1 \quad<0.1<5 \quad<5 \quad 103 \quad 9$ $<0.1<0.1 \quad<0.1<5 \quad 14 \quad 186 \quad 40$ $<0.1<0.1 \quad<0.1<5 \quad 7 \quad 136 \quad 13$ $<0.1<0.1 \quad<0.1<5 \quad 9 \quad 335 \quad 29$ $\begin{array}{lllllll}<0.1 & <0.1 & 0.16 & <5 & 6 & 248 & 33 \\ <0.1 & <0.1 & <0.1 & <5 & 6 & 125 & 18\end{array}$ $\begin{array}{llllllll}<0.1 & <0.1 & <0.1 & <5 & 6 & 125 & 18 \\ <0.1 & <0.1 & <0.1 & <5 & 11 & 372 & 46\end{array}$ $<0.1<0.1 \quad 0.12<5 \quad 20 \quad 184651$ $\begin{array}{llllll}< & 116 & 6 & 438 & 106<10 & 5\end{array}$ $<0.1<0.1 \quad 1.63<5 \quad 5 \quad 142<5 \quad 6 \quad<5 \quad<10 \quad 5$

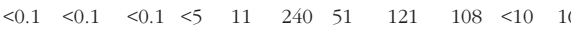
$\begin{array}{lllllllllll}<0.1 & <0.1 & <0.1 & <5 & 8 & 188 & 15 & 281 & 112 & <10 & 13\end{array}$

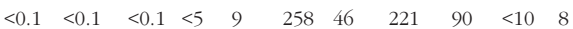
$\begin{array}{llllllllllllllllll}0.11 & 0.22 & <0.1 & 6 & 8 & 101 & 18 & 104 & 7 & <10 & 10 & <10 & 50 & 50 & <5 & 29 & <10 & 62\end{array}$ $\begin{array}{lllllllllllllll}<10 & <10 & 10 & 41 & <10 & <5 & <15 & 5 & 55 & 46 & 21 & 39 & <10 & <10 & <10\end{array}$ $\begin{array}{lllllllllllllll}<10 & <10 & 15 & 38 & <10 & <5 & <15 & 6 & 28 & 16 & 15 & 39 & <10 & <10 & <10\end{array}$

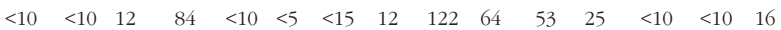
$\begin{array}{lllllllllllllll}<10 & <10 & 11 & 41 & <10 & <5 & <15 & 7 & 67 & 55 & 19 & 29 & <10 & <10 & <10\end{array}$ $\begin{array}{lllllllllllllll}<10 & <10 & 10 & 58 & <10 & <5 & <15 & 6 & 28 & 21 & 10 & 34 & <10 & <10 & <10\end{array}$ $\begin{array}{lllllllllllllll}<10 & <10 & <10 & 44 & <10 & <5 & <15 & 6 & 25 & 13 & <10 & 36 & <10 & <10 & <10\end{array}$ $\begin{array}{lllllllllllllll}<10 & <10 & <10 & 43 & <10 & 5 & <15 & <5 & 108 & 84 & 32 & 37 & <10 & <10 & 13\end{array}$ $\begin{array}{lllllllllllllll}<10 & <10 & <10 & 22 & <10 & <5 & <15 & <5 & 73 & 57 & 25 & 35 & <10 & <10 & <10\end{array}$ $\begin{array}{lllllllllllllll}<10 & <10 & 12 & 65 & <10 & 6 & <15 & 6 & 104 & 51 & 48 & 35 & <10 & <10 & 10\end{array}$ $\begin{array}{lllllllllllllll}<10 & <10 & 11 & 36 & <10 & <5 & <15 & <5 & 183 & 101 & 61 & 33 & <10 & <10 & 19\end{array}$ $\begin{array}{lllllllllllllll}<10 & <10 & <10 & 35 & <10 & <5 & <15 & 6 & 68 & 39 & 22 & 30 & <10 & <10 & <10\end{array}$ $\begin{array}{lllllllllllllll}<10 & <10 & <10 & 39 & <10 & <5 & <15 & <5 & 27 & 23 & 11 & 34 & <10 & <10 & <10\end{array}$ $\begin{array}{lllllllllllllll}<10 & <10 & <10 & 30 & <10 & <5 & <15 & <5 & 88 & 56 & 26 & 37 & <10 & <10 & <10\end{array}$ $\begin{array}{lllllllllllllll}<10 & <10 & 11 & 56 & <10 & 5 & <15 & 8 & 110 & 79 & 51 & 33 & <10 & <10 & 15\end{array}$ $\begin{array}{lllllllllllllll}<10 & <10 & 11 & 41 & <10 & <5 & <15 & 7 & 15 & 27 & <10 & 25 & <10 & <10 & <10\end{array}$ $\begin{array}{lllllllllllllll}<10 & <10 & 21 & 80 & <10 & <5 & <15 & 5 & 94 & 64 & 48 & 37 & <10 & <10 & 11\end{array}$ $\begin{array}{lllllllllllllll}<10 & <10 & 10 & 50 & <10 & <5 & <15 & 7 & 59 & 34 & 21 & 34 & <10 & <10 & <10\end{array}$ $\begin{array}{lllllllllllllll}<10 & <10 & 10 & 20 & <10 & <5 & <15 & <5 & 38 & 26 & 18 & 39 & <10 & <10 & <10\end{array}$ $\begin{array}{lllllllllllllll}<10 & <10 & 10 & 37 & 11 & <5 & <15 & 10 & 21 & <10 & <10 & 32 & <10 & <10 & <10\end{array}$ $\begin{array}{lllllllllllllll}<10 & <10 & 10 & 25 & <10 & <5 & <15 & <5 & 92 & 16 & 10 & 36 & <10 & <10 & <10\end{array}$ $\begin{array}{lllllllllllllll}<10 & <10 & 10 & 30 & <10 & <5 & <15 & <5 & 11 & <10 & <10 & 39 & <10 & <10 & <10\end{array}$ $\begin{array}{lllllllllllllll}<10 & <10 & <10 & 84 & <10 & <5 & <15 & 10 & 74 & 31 & 35 & 31 & <10 & <10 & <10\end{array}$ $\begin{array}{lllllllllllllll}<10 & <10 & 14 & 56 & <10 & <5 & <15 & 5 & 133 & 85 & 47 & 29 & <10 & <10 & 13\end{array}$ $\begin{array}{lllllllllllllll}<10 & <10 & <10 & 48 & 19 & <5 & <15 & <5 & 247 & 171 & 69 & 26 & 15 & <10 & 24\end{array}$ $\begin{array}{lllllllllllllll}<10 & <10 & <10 & 58 & <10 & 12 & <15 & 9 & 66 & 44 & 27 & 35 & <10 & <10 & <10\end{array}$ $\begin{array}{lllllllllllllll}<10 & <10 & 12 & 47 & 14 & <5 & <15 & <5 & 204 & 147 & 68 & 33 & <10 & <10 & 23\end{array}$ $\begin{array}{lllllllllllllll}<10 & <10 & <10 & 99 & <10 & 44 & <15 & 17 & 58 & 28 & 41 & 19 & 12 & <10 & 14\end{array}$ $\begin{array}{lllllllllllllll}<10 & <10 & <10 & 46 & <10 & <5 & <15 & <5 & 94 & 71 & 31 & 37 & <10 & <10 & <10\end{array}$ $\begin{array}{lllllllllllllll}<10 & <10 & 11 & 66 & <10 & <5 & <15 & 8 & 36 & 21 & 19 & 32 & <10 & <10 & <10\end{array}$ $\begin{array}{lllllllllllllll}<10 & <10 & <10 & 49 & 23 & 274 & <15 & 55 & 26 & <10 & <10 & 11 & <10 & <10 & <10\end{array}$

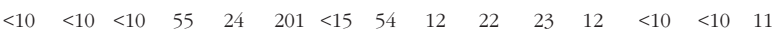
$\begin{array}{lllllllllllllll}<10 & <10 & <10 & 102 & 19 & 34 & <15 & 19 & 47 & 24 & 23 & 20 & 13 & <10 & <10\end{array}$ $\begin{array}{lllllllllllllll}<10 & <10 & 10 & 45 & 10 & <5 & <15 & <5 & 18 & 20 & <10 & 36 & <10 & <10 & <10\end{array}$ $\begin{array}{lllllllllllllll}<10 & <10 & <10 & 38 & <10 & <5 & <15 & <5 & 30 & 15 & <10 & 37 & <10 & <10 & <10\end{array}$ $\begin{array}{lllllllllllllll}10 & <10 & 15 & 122 & 80 & 41 & <15 & 57 & 59 & 21 & 41 & 10 & <10 & 17 & <10\end{array}$ $\begin{array}{lllllllllllllll}<10 & <10 & 11 & 28 & <10 & <5 & <15 & <5 & 70 & 63 & 29 & 33 & <10 & <10 & <10\end{array}$ $\begin{array}{lllllllllllllll}<10 & <10 & 17 & 16 & 13 & <5 & <15 & 8 & 75 & 47 & 36 & 34 & <10 & <10 & 10\end{array}$ $\begin{array}{lllllllllllllll}<10 & <10 & 15 & 8 & 246 & 36 & <15 & 56 & 45 & 20 & 15 & 28 & <10 & <10 & <10\end{array}$ $\begin{array}{lllllllllllllll}19 & 10 & 26 & 18 & 224 & 35 & <15 & 209 & <10 & 21 & <10 & <10 & <10 & 112 & 44\end{array}$ $\begin{array}{lllllllllllllll}<10 & <10 & 11 & 55 & 37 & 19 & <15 & 13 & 55 & 35 & 22 & 28 & <10 & <10 & 11\end{array}$ $\begin{array}{lllllllllllllll}<10 & <10 & <10 & 30 & <10 & <5 & <15 & <5 & 45 & 22 & 19 & 33 & <10 & <10 & <10\end{array}$ $\begin{array}{lllllllllllllll}<10 & <10 & 18 & 31 & 22 & <5 & <15 & 7 & 55 & 42 & 15 & 37 & <10 & <10 & <10\end{array}$ $\begin{array}{lllllllllllllll}<10 & <10 & <10 & 51 & 10 & <5 & <15 & 5 & <10 & <10 & <10 & 29 & <10 & <10 & <10\end{array}$ $\begin{array}{lllllllllllllll}<10 & <10 & <10 & 24 & <10 & 6 & <15 & <5 & 53 & 36 & 30 & 42 & <10 & <10 & <10\end{array}$ $\begin{array}{lllllllllllllll}<10 & <10 & 14 & 95 & 30 & 14 & <15 & 20 & 125 & 57 & 55 & 21 & <10 & <10 & 10\end{array}$ $\begin{array}{lllllllllllllll}<10 & <10 & 13 & 41 & 20 & 7 & <15 & 7 & 60 & 33 & 23 & 30 & <10 & <10 & <10\end{array}$ $\begin{array}{lllllllllllllll}<10 & <10 & 14 & 45 & <10 & 6 & <15 & 5 & 32 & 13 & <10 & 30 & <10 & <10 & <10\end{array}$ $\begin{array}{lllllllllllllll}<10 & <10 & 13 & 34 & <10 & <5 & <15 & <5 & 76 & 59 & 30 & 36 & <10 & <10 & <10\end{array}$ $\begin{array}{lllllllllllllll}<10 & <10 & 11 & 42 & <10 & 5 & <15 & 8 & 64 & 45 & 27 & 34 & <10 & <10 & <10\end{array}$ $\begin{array}{lllllllllllllll}<10 & <10 & <10 & 31 & <10 & <5 & <15 & <5 & 118 & 48 & 28 & 31 & <10 & <10 & <10\end{array}$ $\begin{array}{lllllllllllllll}<10 & <10 & 14 & 91 & 13 & 11 & <15 & 7 & 231 & 98 & 115 & 10 & 26 & <10 & 27\end{array}$ $\begin{array}{lllllllllllllll}<10 & <10 & 11 & 44 & 18 & 6 & <15 & <5 & 54 & 28 & 20 & 37 & <10 & <10 & <10\end{array}$ $\begin{array}{lllllllllllllll}<10 & <10 & 19 & 65 & 14 & <5 & <15 & 7 & 112 & 48 & 45 & 30 & 10 & 10 & 12\end{array}$ $\begin{array}{lllllllllllllll}<10 & <10 & 33 & 26 & <10 & 25 & <15 & 9 & 282 & 112 & 126 & <10 & 11 & 21 & 33\end{array}$ $\begin{array}{lllllllllllllll}<10 & <10 & 11 & 83 & 13 & 13 & <15 & 16 & 38 & 24 & 18 & 25 & 12 & <10 & <10\end{array}$ $\begin{array}{lllllllllllllll}<10 & <10 & <10 & 47 & <10 & 14 & <15 & 10 & 40 & 35 & 15 & 34 & <10 & <10 & <10\end{array}$ $\begin{array}{lllllllllllllll}<10 & <10 & 13 & 32 & <10 & <5 & <15 & <5 & 38 & 28 & 15 & 36 & <10 & <10 & <10\end{array}$ $\begin{array}{lllllllllllllll}<10 & <10 & <10 & 12 & <10 & <5 & <15 & <5 & <10 & <10 & <10 & 47 & <10 & <10 & <10\end{array}$ $\begin{array}{lllllllllllllll}<10 & <10 & 11 & 60 & <10 & 6 & <15 & 8 & 75 & 44 & 36 & 36 & <10 & <10 & <10\end{array}$ $\begin{array}{lllllllllllllll}<10 & <10 & <10 & 41 & <10 & <5 & <15 & 5 & 59 & 45 & 23 & 33 & 11 & <10 & <10\end{array}$ $\begin{array}{lllllllllllllll}<10 & <10 & 12 & 77 & 27 & 8 & <15 & 15 & 77 & 46 & 35 & 30 & <10 & <10 & 13\end{array}$ $\begin{array}{lllllllllllllll}<10 & <10 & 11 & 81 & <10 & 15 & <15 & 21 & 48 & 33 & 18 & 30 & <10 & <10 & <10\end{array}$ \begin{tabular}{lllllllllllllll}
$<10$ & $<10$ & $<10$ & 426 & $<10$ & 24 & $<15$ & 21 & 50 & $<10$ & 17 & 15 & $<10$ & 11 & $<10$ \\
\hline
\end{tabular} 


\begin{tabular}{|c|c|c|c|c|c|c|c|c|c|c|c|c|c|c|c|c|c|c|}
\hline Sample & UTM, E & UTM, $\mathbf{N}$ & Zone & Field name & Tectonic Unit & $\mathrm{SiO}_{2}$ & $\mathrm{TiO}_{2}$ & $\mathrm{Al}_{2} \mathrm{O}_{3}$ & $\mathrm{Fe}_{2} \mathrm{O}_{3}$ & FeOt & Mgo & $\mathrm{CaO}$ & $\mathrm{Na}_{2} \mathrm{O}$ & $\mathbf{K}_{2} \mathrm{O}$ & Mno & $\mathbf{P}_{2} \mathrm{O}_{5}$ & Gl.tap & sum \\
\hline 37286 & 395318 & 8656352 & 37 & Granitic gneiss & Marrupa Complex & 65.17 & 0.95 & 15.02 & 4.27 & 3.84 & 1.06 & 2.01 & 3.25 & 5.41 & 0.04 & 0.32 & 0.60 & 98.09 \\
\hline 37260 & 396411 & 8654206 & 37 & Granodioritic migmatitic gneiss & Marrupa Complex & 69.08 & 0.41 & 14.92 & 2.13 & 1.92 & 0.70 & 2.13 & 2.70 & 6.05 & 0.03 & 0.12 & 0.46 & 98.74 \\
\hline 37284 & 397954 & 8700928 & 37 & Granitic/granodioritic migmatitic gneiss & Marrupa Complex & 70.96 & 0.35 & 14.37 & 2.28 & 2.05 & 0.91 & 1.91 & 3.30 & 4.14 & 0.03 & 0.13 & 0.32 & 98.70 \\
\hline 26832 & 399129 & 8441659 & 37 & Banded migmatite; Bt-Pl-Qtz gneiss (615) & Marrupa Complex & 69.82 & 0.37 & 14.88 & 3.12 & 2.81 & 0.70 & 2.30 & 4.28 & 2.86 & 0.05 & 0.12 & 0.26 & 98.77 \\
\hline 26802 & 407616 & 8416103 & 37 & Granitic gneiss (614) & Marrupa Complex & 69.31 & 0.46 & 14.09 & 3.79 & 3.41 & 0.44 & 1.72 & 3.36 & 4.97 & 0.04 & 0.15 & 0.13 & 98.46 \\
\hline 38418 & 409347 & 8593708 & 37 & Gabbro & Marrupa Complex & 42.33 & 4.70 & 14.49 & 17.49 & 15.74 & 6.33 & 7.99 & 2.80 & 1.05 & 0.20 & 1.21 & -0.28 & 98.30 \\
\hline 33224 & 414058 & 8513166 & 37 & Granitic gneiss & Marrupa Complex & 73.68 & 0.06 & 14.47 & 0.68 & 0.61 & 0.06 & 0.66 & 4.33 & 3.81 & 0.12 & 0.01 & 0.47 & 98.35 \\
\hline 37259 & 414923 & 8731530 & 37 & Pyroxene-amphibolitic gneiss & Marrupa Complex & 48.44 & 0.46 & 11.92 & 9.91 & 8.92 & 8.86 & 16.58 & 1.24 & 0.51 & 0.24 & 0.22 & 0.61 & 99.00 \\
\hline 26816 & 418246 & 8414883 & 37 & Bt-Pl-Qtz gneiss, migmatised (211) & Marrupa Complex & 69.28 & 0.30 & 15.23 & 2.84 & 2.56 & 0.61 & 2.00 & 3.88 & 4.27 & 0.03 & 0.06 & 0.22 & 98.73 \\
\hline 39299 & 418530 & 8654549 & 37 & Migmatitic gneiss & Marrupa Complex & 55.13 & 0.74 & 16.90 & 6.79 & 6.11 & 4.14 & 9.01 & 4.13 & 1.03 & 0.06 & 0.28 & 0.25 & 98.45 \\
\hline 38417 & 419068 & 8597970 & 37 & Granite & Marrupa Complex & 68.85 & 0.18 & 15.56 & 1.79 & 1.61 & 0.35 & 2.50 & 4.55 & 2.78 & 0.03 & 0.06 & 0.31 & 96.97 \\
\hline 38440 & 420673 & 8618820 & 37 & Magnetite quartzite & Marrupa Complex & 50.41 & 0.03 & 0.33 & 43.98 & 39.58 & 2.33 & 0.88 & 0.13 & 0.02 & 0.07 & 0.34 & -0.53 & 98.00 \\
\hline 38439 & 422942 & 8616110 & 37 & Granitic gneiss & Marrupa Complex & 73.81 & 0.09 & 13.69 & 0.91 & 0.82 & 0.10 & 0.56 & 3.45 & 5.66 & $<0.01$ & 0.02 & 0.38 & 98.68 \\
\hline 37293 & 432054 & 8717276 & 37 & Granitic gneiss & Marrupa Complex & 59.30 & 0.95 & 12.98 & 4.55 & 4.10 & 2.34 & 6.51 & 3.39 & 5.74 & 0.14 & 0.72 & 0.56 & 97.17 \\
\hline 26807 & 459235 & 8433529 & 37 & Leucogneiss (612) & Marrupa Complex & 73.91 & 0.16 & 13.29 & 1.27 & 1.14 & 0.14 & 1.39 & 3.28 & 5.11 & 0.02 & 0.02 & 0.14 & 98.75 \\
\hline 26895 & 284470 & 8396343 & 37 & Foliated (early) Pan-African granitoid (104) & Marrupa Complex & 61.41 & 1.30 & 14.78 & 6.64 & 5.98 & 1.20 & 2.93 & 5.27 & 3.37 & 0.21 & 0.54 & 0.54 & 98.18 \\
\hline 26892 & 291146 & 8381529 & 37 & Coarse syenitic gneiss (603) & Marrupa Complex & 56.43 & 1.01 & 12.25 & 6.96 & 6.26 & 2.24 & 8.78 & 4.31 & 4.19 & 0.25 & 1.57 & 0.31 & 98.30 \\
\hline 26893 & 291146 & 8381529 & 37 & Coarse syenitic gneiss (603) & Marrupa Complex & 62.17 & 0.18 & 17.46 & 2.68 & 2.41 & 0.82 & 4.43 & 6.58 & 3.35 & 0.07 & 0.53 & 0.53 & 98.81 \\
\hline 26867 & 313991 & 8395322 & 37 & Felsic gneiss (612) & Marrupa Complex & 78.54 & 0.06 & 11.40 & 1.45 & 1.31 & $<0.01$ & 0.30 & 3.42 & 4.47 & $<0.01$ & 0.03 & 0.20 & 99.87 \\
\hline 26868 & 322724 & 8394901 & 37 & Leucogneiss-granulite (612) & Marrupa Complex & 73.85 & 0.25 & 12.72 & 3.26 & 2.93 & 0.54 & 2.88 & 3.84 & 0.94 & 0.08 & 0.06 & 0.31 & 98.73 \\
\hline 26889 & 328871 & 8417793 & 37 & Biotite leucogneiss/migmatite (614) & Marrupa Complex & 69.05 & 0.63 & 14.84 & 3.37 & 3.03 & 0.64 & 1.91 & 3.89 & 4.23 & 0.04 & 0.18 & 0.20 & 98.98 \\
\hline 26888 & 328871 & 8417793 & 37 & Biotite leucogneiss/migmatite (614) & Marrupa Complex & 72.02 & 0.18 & 13.99 & 1.34 & 1.21 & 0.21 & 1.15 & 3.21 & 5.75 & 0.02 & 0.04 & 0.30 & 98.20 \\
\hline 26865 & 329536 & 8420085 & 37 & Migmatitic Bt gneiss (602) & Marrupa Complex & 69.80 & 0.68 & 13.28 & 4.42 & 3.98 & 1.84 & 2.78 & 3.50 & 2.09 & 0.06 & 0.11 & 0.40 & 98.97 \\
\hline 26864 & 343847 & 8411289 & 37 & Bt gneiss (612) & Marrupa Complex & 75.06 & 0.09 & 13.31 & 0.87 & 0.78 & 0.09 & 0.77 & 4.29 & 4.06 & 0.13 & 0.03 & 0.18 & 98.87 \\
\hline 33325 & 493489 & 8577448 & 37 & Felsic orthogneiss & Nairoto Complex & 69.19 & 0.43 & 14.56 & 3.37 & 3.03 & 1.75 & 3.39 & 3.62 & 2.31 & 0.06 & 0.10 & 0.38 & 99.17 \\
\hline 36076 & 515172 & 8600890 & 37 & Tonalitic gneiss & Nairoto Complex & 60.38 & 0.69 & 16.05 & 7.38 & 6.64 & 2.79 & 6.43 & 3.71 & 1.22 & 0.14 & 0.16 & 0.25 & 99.20 \\
\hline 40711 & 515824 & 8656296 & 37 & Granitic gneiss & Nairoto Complex & 70.13 & 0.42 & 14.46 & 2.96 & 2.66 & 0.82 & 3.21 & 3.57 & 3.30 & 0.05 & 0.10 & 0.19 & 99.20 \\
\hline 40651 & 528365 & 8714714 & 37 & Granitic gneiss & Nairoto Complex & 70.78 & 0.50 & 14.23 & 2.60 & 2.34 & 0.76 & 1.93 & 3.52 & 4.42 & 0.04 & 0.11 & 0.39 & 99.28 \\
\hline 40678 & 630566 & 8532440 & 37 & Metagabbro & Nairoto Complex & 43.53 & 1.91 & 12.56 & 10.76 & 9.68 & 5.03 & 20.98 & 0.98 & 0.06 & 0.18 & 0.20 & 1.40 & 97.59 \\
\hline 40679 & 631031 & 8532582 & 37 & Graphite-bearing biotite gneiss & Nairoto Complex & 76.04 & 0.47 & 3.09 & 0.52 & 0.47 & 0.24 & 0.61 & 0.78 & 0.31 & 0.01 & 0.05 & 16.80 & 98.91 \\
\hline 33350 & 484783 & 8570670 & 37 & Granodioritic gneiss & Nairoto Complex & 73.40 & 0.26 & 13.83 & 1.68 & 1.51 & 0.36 & 1.61 & 4.49 & 2.69 & 0.04 & 0.09 & 0.26 & 98.71 \\
\hline 33229 & 593522 & 8543084 & 37 & Granitic gneiss & Meluco Complex & 71.60 & 0.28 & 14.11 & 2.25 & 2.03 & 0.33 & 1.09 & 3.98 & 4.33 & 0.04 & 0.06 & 0.32 & 98.39 \\
\hline 33237 & 597369 & 8543762 & 37 & Granitic gneiss/foliated granite & Meluco Complex & 72.47 & 0.21 & 14.48 & 1.30 & 1.17 & 0.24 & 1.19 & 3.77 & 4.69 & 0.02 & 0.05 & 0.15 & 98.56 \\
\hline 40760 & 611174 & 8600264 & 37 & Granitic gneiss & Meluco Complex & 66.89 & 0.56 & 15.75 & 2.89 & 2.60 & 0.59 & 2.02 & 4.00 & 5.75 & 0.06 & 0.14 & 0.24 & 98.90 \\
\hline 40672 & 618589 & 8584524 & 37 & Granodioritic gneiss & Meluco Complex & 68.71 & 0.36 & 15.10 & 3.43 & 3.09 & 0.44 & 2.35 & 4.88 & 2.95 & 0.06 & 0.10 & 0.33 & 98.72 \\
\hline 38431 & 426828 & 8595106 & 37 & Granitic gneiss & Xixano Complex & 77.74 & 0.18 & 11.09 & 2.01 & 1.81 & 0.23 & 0.08 & 2.08 & 5.67 & 0.01 & 0.02 & 0.56 & 99.67 \\
\hline 38434 & 428500 & 8580668 & 37 & Granodioritic gniess & Xixano Complex & 70.25 & 0.32 & 14.69 & 2.67 & 2.40 & 0.37 & 1.35 & 3.94 & 4.51 & 0.05 & 0.13 & 0.19 & 98.47 \\
\hline 36091 & 430722 & 8614486 & 37 & ACID META-VOLCANIC & Xixano Complex & 66.22 & 0.36 & 14.24 & 7.22 & 6.50 & 0.08 & 0.18 & 4.62 & 3.56 & 0.03 & 0.05 & 0.79 & 97.35 \\
\hline 36090 & 431804 & 8609430 & 37 & QUARTZO-FELDSPATHIC GNEISS & Xixano Complex & 77.31 & 0.14 & 12.51 & 1.69 & 1.52 & 0.21 & 1.05 & 3.63 & 1.84 & 0.01 & 0.01 & 0.72 & 99.12 \\
\hline 36089 & 432908 & 8565660 & 37 & MAFIC DYKE & Xixano Complex & 46.96 & 0.66 & 14.12 & 10.14 & 9.13 & 14.19 & 10.24 & 1.29 & 0.09 & 0.16 & 0.03 & 0.82 & 98.71 \\
\hline 36093 & 433001 & 8602358 & 37 & ????????? & Xixano Complex & 61.73 & 2.50 & 11.85 & 4.35 & 3.92 & 2.05 & 1.54 & 0.89 & 11.51 & 0.04 & 1.20 & 0.52 & 98.19 \\
\hline 36092 & 433080 & 8606504 & 37 & QUARTZO-FELDSPATHIC GNEISS & Xixano Complex & 73.59 & 0.02 & 15.45 & 0.30 & 0.27 & 0.05 & 1.16 & 4.02 & 3.92 & $<0.01$ & 0.01 & 0.50 & 99.03 \\
\hline 33387 & 434208 & 8549406 & 37 & Psammite & Xixano Complex & 67.48 & 0.54 & 15.03 & 3.49 & 3.14 & 0.35 & 0.08 & 1.08 & 3.68 & 0.03 & 0.04 & 7.45 & 99.27 \\
\hline 36082 & 434745 & 8597938 & 37 & BASIC-INTERMEDIATE PORPHYRY & Xixano Complex & 51.09 & 0.70 & 14.29 & 10.57 & 9.51 & 7.09 & 10.27 & 1.88 & 0.86 & 0.17 & 0.12 & 1.51 & 98.56 \\
\hline 33221 & 437435 & 8538564 & 37 & Leucogranitic gneiss & Xixano Complex & 71.54 & 0.08 & 15.87 & 0.89 & 0.80 & 0.10 & 1.83 & 6.07 & 1.26 & 0.03 & 0.03 & 0.53 & 98.23 \\
\hline 36095 & 438015 & 8573770 & 37 & ACID META-VOLCANIC & Xixano Complex & 66.53 & 0.48 & 14.56 & 5.60 & 5.04 & 0.17 & 0.50 & 3.92 & 5.60 & 0.05 & 0.07 & 0.70 & 98.18 \\
\hline 37207 & 439222 & 8639514 & 37 & META-RHYOLITE & Xixano Complex & 76.35 & 0.17 & 11.80 & 1.54 & 1.39 & 0.18 & 0.17 & 2.85 & 5.30 & 0.02 & 0.03 & 0.65 & 99.05 \\
\hline 33219 & 440079 & 8545636 & 37 & Quartz, coarse grained & Xixano Complex & 98.44 & 0.377 & 0.25 & 0.346 & 0.31 & $<0.01$ & 0.02 & $<0.1$ & 0.069 & $<0.01$ & $<0.01$ & 0.31 & 99.78 \\
\hline 40717 & 441794 & 8732349 & 37 & Tonalitic gneiss & Xixano Complex & 57.57 & 0.79 & 13.90 & 4.11 & 3.70 & 1.93 & 6.32 & 1.74 & 8.30 & 0.09 & 1.06 & 0.31 & 96.10 \\
\hline 36098 & 442024 & 8572554 & 37 & ACID META-VOLCANIC & Xixano Complex & 56.16 & 0.95 & 20.03 & 12.26 & 11.03 & 0.23 & 0.08 & 1.94 & 2.71 & 0.02 & 0.06 & 4.16 & 98.61 \\
\hline 40755 & 442660 & 8733158 & 37 & Amphibolitic gneiss & Xixano Complex & 49.77 & 1.00 & 16.80 & 10.21 & 9.19 & 4.99 & 9.48 & 3.20 & 2.02 & 0.18 & 0.44 & 0.62 & 98.70 \\
\hline 36100 & 443405 & 8663222 & 37 & GRANITIC GNEISS & Xixano Complex & 72.51 & 0.19 & 13.86 & 1.53 & 1.38 & 0.24 & 1.06 & 3.30 & 5.22 & 0.03 & 0.06 & 0.31 & 98.30 \\
\hline 33402 & 445921 & 8584552 & 37 & Paragneiss & Xixano Complex & 74.44 & 0.22 & 13.12 & 2.98 & 2.68 & 0.48 & 1.48 & 4.42 & 1.20 & 0.04 & 0.05 & 0.54 & 98.98 \\
\hline 33388 & 450870 & 8497866 & 37 & Meta-volcanic & Xixano Complex & 72.55 & 0.29 & 13.73 & 2.93 & 2.64 & 0.90 & 4.01 & 4.20 & 0.13 & 0.08 & 0.07 & 0.20 & 99.10 \\
\hline 33339 & 451029 & 8589856 & 37 & Leucogranite & Xixano Complex & 75.22 & 0.16 & 11.88 & 1.49 & 1.34 & 0.13 & 0.31 & 3.42 & 4.76 & 0.02 & 0.02 & 0.47 & 97.89 \\
\hline 33227 & 455437 & 8511024 & 37 & Granodioritic gneiss & Xixano Complex & 69.70 & 0.37 & 15.22 & 2.68 & 2.41 & 0.66 & 1.77 & 4.95 & 2.46 & 0.09 & 0.08 & 0.71 & 98.70 \\
\hline 38424 & 457210 & 8658340 & 37 & Amphibolite & Xixano Complex & 60.29 & 1.24 & 13.31 & 11.85 & 10.67 & 1.64 & 7.05 & 2.64 & 0.24 & 0.15 & 0.47 & 0.17 & 99.05 \\
\hline 33410 & 459178 & 8514153 & 37 & Metarhyolite & Xixano Complex & 75.64 & 0.16 & 12.36 & 1.99 & 1.79 & 0.09 & 0.47 & 4.48 & 3.41 & 0.01 & 0.03 & 0.20 & 98.85 \\
\hline 38448 & 459996 & 8655862 & 37 & Quartz monzonite & Xixano Complex & 64.87 & 0.51 & 15.24 & 6.87 & 6.18 & 1.79 & 5.72 & 3.16 & 0.18 & 0.13 & 0.13 & 0.21 & 98.83 \\
\hline 38423 & 460170 & 8659398 & 37 & Gabbro & Xixano Complex & 49.55 & 0.52 & 17.09 & 13.71 & 12.34 & 5.59 & 10.30 & 2.14 & 0.08 & 0.25 & 0.09 & 0.21 & 99.53 \\
\hline 33320 & 464144 & 8527556 & 37 & Mica schist & Xixano Complex & 73.90 & 1.426 & 9.66 & 0.690 & 0.62 & 0.42 & 0.24 & 0.44 & 1.565 & $<0.01$ & 0.051 & 10.73 & 99.15 \\
\hline 38445 & 464431 & 8659782 & 37 & Quartz diorite & Xixano Complex & 65.92 & 0.46 & 14.68 & 6.69 & 6.02 & 1.51 & 6.16 & 2.94 & 0.32 & 0.13 & 0.13 & 0.44 & 99.37 \\
\hline 37204 & 465305 & 8666804 & 37 & PYROXENITE & Xixano Complex & 44.04 & 0.78 & 19.83 & 15.09 & 13.58 & 5.40 & 12.19 & 0.90 & 0.06 & 0.21 & 0.02 & 0.97 & 99.49 \\
\hline 38422 & 466079 & 8659434 & 37 & Quartz diorite & Xixano Complex & 69.33 & 0.48 & 13.92 & 4.04 & 3.64 & 1.40 & 5.84 & 3.08 & 0.24 & 0.08 & 0.14 & 0.37 & 98.91 \\
\hline 38443 & 466693 & 8608060 & 37 & Metagabbro & Xixano Complex & 46.83 & 1.93 & 15.91 & 13.58 & 12.22 & 8.15 & 9.87 & 2.67 & 0.11 & 0.22 & 0.24 & 0.30 & 99.80 \\
\hline 36052 & 467750 & 8658406 & 37 & Granodioritic gneiss & Xixano Complex & 71.67 & 0.28 & 13.14 & 4.49 & 4.04 & 0.87 & 4.42 & 2.89 & 0.42 & 0.10 & 0.08 & 0.51 & 98.89 \\
\hline
\end{tabular}




$\begin{array}{lllllllllllllllllllllllllllllllllllll}\mathbf{S} & \mathbf{C l} & \mathbf{F} & \mathbf{M o} & \mathbf{N b} & \mathbf{Z r} & \mathbf{Y} & \mathbf{S r} & \mathbf{R b} & \mathbf{U} & \mathbf{T h} & \mathbf{P b} & \mathbf{C r} & \mathbf{V} & \mathbf{A s} & \mathbf{S c} & \mathbf{H f} & \mathbf{B a} & \mathbf{S b} & \mathbf{S n} & \mathbf{G a} & \mathbf{Z n} & \mathbf{C u} & \mathbf{N i} & \mathbf{Y b} & \mathbf{C o} & \mathbf{C e} & \mathbf{L a} & \mathbf{N d} & \mathbf{w} & \mathbf{C s} & \mathbf{T a} & \mathbf{P r} \\ <0.1 & <0.1 & <0.1 & <5 & 14 & 663 & 49 & 456 & 209 & <10 & 69 & 30 & 10 & 51 & <5 & <10 & 13 & 2628 & <10 & 10 & 16 & 75 & 21 & 8 & <15 & 5 & 628 & 454 & 226 & 21 & 16 & <10 & 79\end{array}$

$\begin{array}{llllllllllllllllllllllllllllllllllllll}<0.1 & <0.1 & <0.1 & <5 & 9 & 151 & 23 & 440 & 120 & <10 & 8 & 22 & 11 & 37 & <5 & <10 & <10 & 2276 & <10 & <10 & <10 & 29 & 14 & <5 & <15 & <5 & 58 & 33 & 25 & 30 & 12 & <10 & <10\end{array}$ $\begin{array}{lllllllllllllllllllllllllllllllllllllll}<0.1 & <0.1 & <0.1 & <5 & 5 & 133 & 5 & 519 & 114 & <10 & 11 & 13 & 17 & 32 & <5 & <10 & <10 & 1659 & <10 & <10 & 12 & 36 & 12 & <5 & <15 & 5 & 71 & 59 & 19 & 30 & <10 & <10 & <10\end{array}$ $\begin{array}{llllllllllllllllllllllllllllllllllll}<0.1 & <0.1 & <0.1 & <5 & 10 & 151 & 14 & 244 & 96 & <10 & 15 & 22 & 10 & 27 & <5 & <10 & <10 & 766 & <10 & <10 & 10 & 62 & 13 & <5 & <15 & 9 & 73 & 40 & 20 & 23 & <10 & <10 & 12\end{array}$ $\begin{array}{llllllllllllllllllllllllllllllllllllllll}<0.1 & <0.1 & <0.1 & <5 & 21 & 362 & 35 & 310 & 199 & <10 & 53 & 22 & 14 & <10 & <5 & <10 & 29 & 1206 & <10 & <10 & 22 & 69 & 11 & <5 & <15 & 5 & 281 & 199 & 81 & 22 & <10 & <10 & 31\end{array}$ $\begin{array}{lllllllllllllllllllllllllllllllllllllllll}<0.1 & <0.1 & 0.23 & <5 & 21 & 138 & 27 & 605 & 16 & <10 & <5 & <10 & 22 & 303 & <5 & 24 & <10 & 512 & <10 & <10 & 14 & 130 & 67 & 83 & <15 & 77 & 76 & 26 & 50 & <10 & 10 & 20 & <10\end{array}$ $\begin{array}{llllllllllllllllll}<0.1 & <0.1 & <0.1 & <5 & 55 & 68 & 33 & 32 & 463 & 12 & 21 & 81 & 12 & <10 & <5 & 10 & <10 & 90\end{array}$ $\begin{array}{lllllllllllllllllll}<0.1 & 0.10 & <0.1 & <5 & 7 & 34 & 14 & 474 & 11 & <10 & <5 & 14 & 531 & 243 & <5 & 51 & 11 & 192\end{array}$

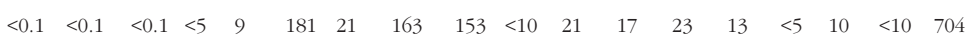
$\begin{array}{llllllllllllllllll}<.1 & <0.1 & 0.11 & <5 & <5 & 93 & 21 & 841 & 6 & <10 & <5 & <10 & 100 & 95 & <5 & 22 & 14 & 142\end{array}$ $\begin{array}{llllllllllllllllll}<0.1 & <0.1 & <0.1 & <5 & <5 & 125 & 6 & 390 & 106 & <10 & 6 & 12 & 13 & 17 & <5 & <10 & <10 & 1114\end{array}$ $\begin{array}{llllllllllllllllll}<0.1 & <0.1 & <0.1 & 6 & 5 & 21 & 12 & 49 & <5 & <10 & 8 & <10 & 76 & 18 & <5 & <10 & <10 & 143\end{array}$

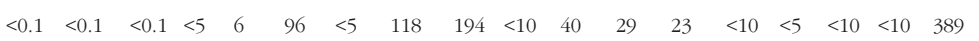
$\begin{array}{llllllllllllllllll}<0.1 & <0.1 & <0.1 & <5 & 33 & 141 & 78 & 3091 & 128 & <10 & 15 & 26 & 11 & 76 & <5 & 15 & 23 & 6672\end{array}$ $\begin{array}{llllllllllllllllll}<0.1 & <0.1 & <0.1 & <5 & 7 & 157 & 28 & 132 & 154 & <10 & 17 & 17 & <10 & <10 & <5 & 10 & <10 & 1062\end{array}$ $\begin{array}{llllllllllllllllll}<0.1 & <0.1 & 0.18 & <5 & 61 & 542 & 60 & 448 & 61 & <10 & 6 & <10 & 11 & 22 & 7 & 14 & 53 & 922\end{array}$ $\begin{array}{llllllllllllllllll}<0.1 & <0.1 & <0.1 & <5 & 106 & 235 & 99 & 516 & 113 & <10 & 18 & 15 & 31 & 55 & <5 & 21 & <10 & 552\end{array}$ $\begin{array}{llllllllllllllllll}<0.1 & <0.1 & <0.1 & <5 & 10 & 311 & 23 & 847 & 69 & <10 & 5 & <10 & 10 & 24 & 7 & <10 & 23 & 535\end{array}$

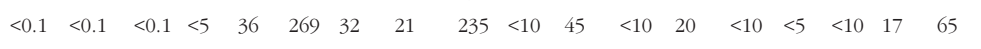
$\begin{array}{llllllllllllllllll}<0.1 & <0.1 & <0.1 & <5 & 6 & 109 & 21 & 138 & 14 & <10 & 8 & <10 & 18 & 25 & 7 & 16 & <10 & 305\end{array}$ $\begin{array}{llllllllllllllllll}<0.1 & <0.1 & <0.1 & <5 & 19 & 347 & 39 & 399 & 169 & <10 & 43 & 25 & 10 & 25 & <5 & <10 & 22 & 1070\end{array}$ $\begin{array}{llllllllllllllllll}<0.1 & <0.1 & <0.1 & <5 & 7 & 110 & 7 & 304 & 203 & <10 & 8 & 28 & <10 & 14 & <5 & <10 & <10 & 1181\end{array}$ $\begin{array}{llllllllllllllllll}<0.1 & <0.1 & <0.1 & <5 & 8 & 215 & 19 & 279 & 70 & <10 & 16 & <10 & 37 & 74 & <5 & 15 & <10 & 640\end{array}$ $\begin{array}{llllllllllllllllll}<0.1 & <0.1 & <0.1 & <5 & 12 & 85 & 99 & 59 & 75 & <10 & 10 & 21 & <10 & 11 & 6 & 12 & <10 & 401\end{array}$ $\begin{array}{lllllllllllllll}<10 & 19 & 34 & 37 & <10 & 10 & <15 & <5 & <10 & <10 & <10 & 37 & <10 & <10 & <10\end{array}$ $\begin{array}{lllllllllllllll}<10 & <10 & <10 & 97 & <10 & 84 & <15 & 39 & 32 & 22 & 18 & 10 & <10 & 10 & <10\end{array}$ $\begin{array}{lllllllllllllll}<10 & 10 & 16 & 45 & 12 & <5 & <15 & 8 & 82 & 33 & 16 & 25 & <10 & <10 & <10\end{array}$ $\begin{array}{lllllllllllllll}<10 & <10 & <10 & 35 & <10 & 38 & <15 & 20 & 54 & 30 & 21 & 23 & <10 & <10 & <10\end{array}$ $\begin{array}{lllllllllllllll}<10 & <10 & <10 & 33 & <10 & <5 & <15 & 5 & 36 & 34 & 10 & 37 & <10 & <10 & <10\end{array}$

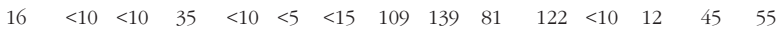
$\begin{array}{lllllllllllllll}<10 & <10 & 12 & 23 & <10 & <5 & <15 & <5 & 24 & 18 & <10 & 36 & <10 & <10 & <10\end{array}$ $\begin{array}{lllllllllllllll}<10 & <10 & 13 & 109 & 10 & 14 & <15 & 5 & 420 & 142 & 218 & 11 & 19 & 10 & 49\end{array}$ $\begin{array}{lllllllllllllll}<10 & <10 & 16 & 26 & 13 & <5 & <15 & 6 & 74 & 51 & 29 & 33 & <10 & <10 & <10\end{array}$ $\begin{array}{lllllllllllllll}<10 & <10 & 21 & 153 & 12 & <5 & <15 & 10 & 147 & 59 & 69 & 10 & <10 & <10 & 19\end{array}$ $\begin{array}{lllllllllllllll}<10 & <10 & 22 & 163 & <10 & 38 & <15 & 13 & 219 & 140 & 145 & 13 & <10 & 16 & 40\end{array}$ $\begin{array}{lllllllllllllll}<10 & <10 & 29 & 45 & 13 & <5 & <15 & 11 & 56 & 26 & 17 & 28 & <10 & <10 & 10\end{array}$ $\begin{array}{lllllllllllllll}<10 & <10 & 24 & 35 & 15 & <5 & <15 & 5 & 67 & 35 & 10 & 30 & <10 & <10 & <10\end{array}$ $\begin{array}{lllllllllllllll}<10 & <10 & 10 & 40 & 11 & <5 & <15 & 10 & 15 & 13 & <10 & 33 & <10 & <10 & <10\end{array}$ $\begin{array}{lllllllllllllll}<10 & <10 & 20 & 68 & 13 & <5 & <15 & 7 & 161 & 92 & 59 & 28 & <10 & <10 & 23\end{array}$ $\begin{array}{lllllllllllllll}<10 & <10 & 18 & 36 & 12 & <5 & <15 & 6 & 19 & 14 & <10 & 25 & <10 & <10 & <10\end{array}$ $\begin{array}{lllllllllllllll}<10 & <10 & 13 & 54 & 23 & 9 & <15 & 12 & 93 & 50 & 33 & 28 & <10 & <10 & 13\end{array}$ $\begin{array}{lllllllllllllll}<10 & <10 & 17 & 79 & 17 & <5 & <15 & 9 & <10 & <10 & <10 & 39 & <10 & <10 & <10\end{array}$

$\begin{array}{llllllllllllllllll}<0.1 & <0.1 & <0.1 & <5 & 7 & 154 & 31 & 330 & 59 & <10 & 7 & <10 & 54 & 57 & 6 & 16 & <10 & 822\end{array}$ $\begin{array}{llllllllllllllllll}<0.1 & <0.1 & <0.1 & <5 & 6 & 121 & 36 & 416 & 28 & <10 & <5 & 12 & 51 & 123 & <5 & 27 & <10 & 368\end{array}$ $\begin{array}{llllllllllllllllll}<0.1 & <0.1 & <0.1 & <5 & 8 & 147 & 21 & 335 & 87 & <10 & 19 & 23 & <10 & 31 & <5 & 14 & <10 & 978\end{array}$

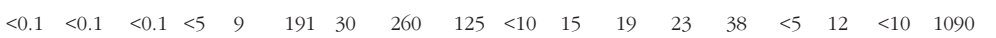
$\begin{array}{llllllllllllllllll}0.65 & <0.1 & <0.1 & <5 & 17 & 111 & 18 & 276 & 5 & <10 & 8 & 11 & 66 & 240 & <5 & 38 & <10 & 49\end{array}$ $\begin{array}{llllllllllllllllll}0.10 & <0.1 & <0.1 & 29 & 9 & 163 & 69 & 74 & 11 & 15 & 12 & 10 & 116 & 686 & <5 & <10 & <10 & 593\end{array}$ $\begin{array}{llllllllllllllllll}<.1 & <0.1 & <0.1 & <5 & 10 & 137 & 34 & 326 & 159 & <10 & 8 & 17 & 29 & 21 & <5 & 10 & <10 & 1397\end{array}$

$\begin{array}{lllllllllllllll}<10 & <10 & 11 & 49 & <10 & 17 & <15 & 11 & 34 & 25 & 17 & 33 & <10 & <10 & <10\end{array}$ $\begin{array}{lllllllllllllll}<10 & <10 & <10 & 81 & 23 & 7 & <15 & 17 & 29 & 13 & 12 & 31 & <10 & <10 & <10\end{array}$ $\begin{array}{lllllllllllllll}<10 & <10 & 10 & 42 & 15 & <5 & <15 & 7 & 63 & 36 & 17 & 25 & <10 & <10 & 12\end{array}$ $\begin{array}{lllllllllllllll}<10 & <10 & 12 & 29 & 27 & <5 & <15 & 9 & 94 & 60 & 33 & 29 & <10 & <10 & 16\end{array}$ $\begin{array}{lllllllllllllll}<10 & <10 & 16 & 95 & 110 & 26 & <15 & 37 & 53 & <10 & 14 & <10 & <10 & 12 & 15\end{array}$ $\begin{array}{lllllllllllllll}<10 & <10 & <10 & 48 & 59 & 5 & <15 & 9 & 26 & 20 & 12 & 47 & <10 & <10 & <10\end{array}$ $\begin{array}{llllllllllllllllllllllllllllllllllllllllll}<0.1 & <0.1 & <0.1 & <5 & 8 & 196 & 36 & 110 & 124 & <10 & 12 & 12 & 12 & 12 & 19 & <10 & <10 & 852 & <10 & <10 & 13 & 47 & <10 & <5 & <15 & 5 & 40 & 29 & 21 & 38 & 11 & <10 & <10\end{array}$ $\begin{array}{llllllllllllllllllllllllllllllllllllll}<0.1 & <0.1 & 0.18 & <5 & 5 & 161 & 13 & 1156 & 97 & 11 & 23 & 50 & 15 & 10 & <5 & <10 & <10 & 2890 & <10 & <10 & 14 & 54 & 10 & <5 & <15 & <5 & 107 & 66 & 25 & 31 & <10 & <10 & <10\end{array}$ $\begin{array}{lllllllllllllllllllllllllllllllllllllllll}<0.1 & <0.1 & <0.1 & <5 & 19 & 369 & 38 & 344 & 119 & <10 & 14 & 26 & <10 & 16 & 5 & 13 & 32 & 2137 & <10 & <10 & 19 & 61 & 14 & <5 & <15 & 8 & 106 & 49 & 42 & 25 & 13 & <10 & <10\end{array}$ $\begin{array}{lllllllllllllllllllllllllllllllllllllllllll}<0.1 & <0.1 & <0.1 & <5 & 17 & 206 & 35 & 184 & 67 & <10 & 10 & 19 & 23 & 17 & <5 & 13 & <10 & 760 & <10 & <10 & 18 & 98 & <10 & <5 & <15 & 10 & 47 & 33 & 29 & 28 & <10 & <10 & 11\end{array}$

$\begin{array}{lllllllllllllllllllllllllllllllllllll}<0.1 & <0.1 & <0.1 & <5 & 92 & 678 & 76 & 12 & 223 & <10 & 21 & 10 & 16 & <10 & <5 & <10 & 29 & 86 & <10 & 11 & 22 & 56 & <10 & 6 & <15 & <5 & 104 & 39 & 37 & 44 & 11 & 11 & <10\end{array}$ $\begin{array}{lllllllllllllllllllllllllllllllllllllllllll}<0.1 & <0.1 & 0.14 & <5 & 26 & 273 & 14 & 291 & 146 & <10 & 21 & 19 & 18 & 12 & <5 & <10 & <10 & 1416 & <10 & <10 & 17 & 85 & <10 & <5 & <15 & <5 & 102 & 67 & 36 & 28 & 13 & <10 & <10\end{array}$ $\begin{array}{lllllllllllllllllllllllllllllllllllll}<0.1 & <0.1 & <0.1 & <5 & 94 & 1287 & 53 & 112 & 63 & <10 & 13 & <10 & <10 & 18 & <5 & <10 & 35 & 1842 & <10 & <10 & 23 & 64 & 17 & <5 & <15 & 12 & 148 & 80 & 80 & 20 & <10 & <10 & 14\end{array}$

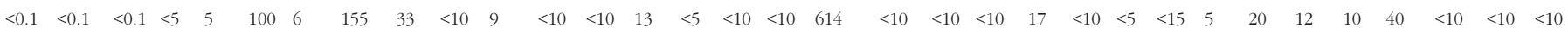
$\begin{array}{lllllllllllllllllllllllllllllllllllllllllllllll}<0.1 & <0.1 & <0.1 & <5 & <5 & 34 & 18 & 114 & <5 & <10 & <5 & <10 & 1036 & 189 & <5 & 37 & <10 & 292 & <10 & <10 & <10 & 70 & 60 & 390 & 20 & 62 & <10 & <10 & <10 & 18 & <10 & <10 & <10\end{array}$ $\begin{array}{lllllllllllllllllllllllllllllllllllllllll}<0.1 & <0.1 & 0.52 & <5 & 23 & 1586 & 11 & 916 & 158 & <10 & 10 & 25 & 69 & 203 & <5 & 15 & 61 & 1036 & <10 & 10 & 19 & 85 & 29 & 60 & <15 & 9 & 99 & 43 & 56 & <10 & <10 & <10 & <10\end{array}$ $\begin{array}{lllllllllllllllllllllllllllllllllllllllllll}<0.1 & <0.1 & <0.1 & <5 & <5 & 20 & <5 & 318 & 25 & <10 & <5 & <10 & <10 & 10 & <5 & <10 & <10 & 3259 & <10 & <10 & <10 & 13 & <10 & <5 & <15 & <5 & <10 & <10 & <10 & 37 & 12 & <10 & <10\end{array}$ $\begin{array}{llllllllllllllllllllllllllllllllllllllllll}<0.1 & <0.1 & <0.1 & 7 & 18 & 198 & 57 & 91 & 124 & <10 & 7 & <10 & 59 & 680 & 41 & 16 & <10 & 940 & <10 & <10 & 17 & 171 & 17 & 20 & <15 & 8 & 49 & 35 & 27 & 35 & <10 & <10 & <10\end{array}$ $\begin{array}{lllllllllllllllllllllllllllllllllllllll}<0.1 & <0.1 & <0.1 & <5 & 7 & 83 & 25 & 205 & 27 & <10 & 8 & <10 & 149 & 240 & <5 & 42 & <10 & 533 & <10 & <10 & <10 & 70 & 110 & 74 & <15 & 46 & 38 & 12 & 15 & 19 & 11 & <10 & <10\end{array}$

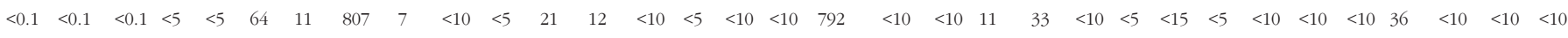
$\begin{array}{llllllllllllllllllllllllllllllllllllllllll}<.1 & <0.1 & <0.1 & <5 & 71 & 638 & 76 & 96 & 42 & <10 & 15 & 15 & <10 & <10 & <5 & <10 & 17 & 1008 & <10 & <10 & 20 & 50 & <10 & 5 & <15 & 8 & 143 & 118 & 99 & 32 & <10 & <10 & 25\end{array}$ $\begin{array}{lllllllllllllllllllllllllllllllllllllllllll}<0.1 & <0.1 & <0.1 & <5 & 52 & 290 & 61 & 26 & 130 & <10 & 15 & <10 & <10 & <10 & <5 & <10 & <10 & 312 & <10 & <10 & 15 & 28 & <10 & <5 & <15 & <5 & 75 & 93 & 59 & 40 & <10 & <10 & 15\end{array}$ $\begin{array}{llllllllllllllllllllllllllllllllllllllllllll}<.1 & <0.1 & <0.1 & <5 & 6 & 112 & <5 & <5 & <5 & <10 & <5 & <10 & <10 & <10 & 20 & <10 & <10 & 16 & <10 & <10 & <10 & 10 & <10 & <5 & <15 & <5 & <10 & <10 & <10 & 42 & <10 & <10 & <10\end{array}$ $\begin{array}{lllllllllllllllllllllllllllllllllllllllll}<0.1 & <0.1 & <0.1 & <5 & 8 & 94 & 35 & 3405 & 198 & <10 & 15 & 26 & 20 & 60 & <5 & 17 & <10 & 12334 & <10 & <10 & 13 & 71 & 29 & <5 & <15 & 5 & 347 & 145 & 115 & <10 & 31 & <10 & 33\end{array}$ $\begin{array}{lllllllllllllllllllllllllllllllllllllllllll}<0.1 & <0.1 & 0.1 & <5 & 14 & 176 & 27 & 190 & 109 & <10 & 22 & <10 & 159 & 221 & <5 & 23 & <10 & 654 & <10 & <10 & 13 & 46 & 24 & 24 & <15 & 21 & 80 & 33 & 38 & 24 & 10 & <10 & 11\end{array}$ $\begin{array}{lllllllllllllllllllllllllllllllllllllllllll}<0.1 & <0.1 & 0.11 & <5 & <5 & 100 & 24 & 347 & 49 & <10 & 5 & 13 & 133 & 228 & <5 & 28 & <10 & 980 & <10 & <10 & 21 & 112 & <10 & 48 & <15 & 28 & 40 & <10 & 14 & <10 & <10 & <10 & <10\end{array}$

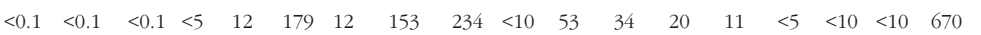

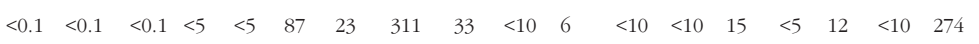

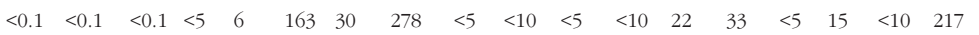
$\begin{array}{llllllllllllllllll}<0.1 & <0.1 & 0.19 & <5 & 153 & 255 & 92 & 34 & 189 & 10 & 51 & <10 & <10 & <10 & <5 & <10 & <10 & 97\end{array}$ $\begin{array}{llllllllllllllllll}<0.1 & <0.1 & <0.1 & <5 & 7 & 158 & 29 & 369 & 33 & <10 & 7 & <10 & 11 & 18 & 5 & 11 & <10 & 1099\end{array}$ $\begin{array}{llllllllllllllllll}<0.1 & <0.1 & 0.11 & <5 & <5 & 74 & 48 & 204 & <5 & <10 & <5 & <10 & 29 & 65 & <5 & 30 & <10 & 90\end{array}$ $\begin{array}{llllllllllllllllll}<0.1 & <0.1 & <0.1 & <5 & 17 & 306 & 82 & 26 & 25 & <10 & 17 & <10 & <10 & <10 & <5 & <10 & <10 & 431\end{array}$ $\begin{array}{llllllllllllllllll}<0.1 & <0.1 & <0.1 & <5 & <5 & 81 & 23 & 213 & <5 & <10 & <5 & <10 & <10 & 87 & <5 & 34 & <10 & 147\end{array}$ $\begin{array}{llllllllllllllllll}<0.1 & <0.1 & <0.1 & <5 & <5 & 23 & 13 & 176 & <5 & <10 & <5 & <10 & 15 & 290 & <5 & 43 & <10 & 69\end{array}$ $\begin{array}{llllllllllllllllll}0.43 & <0.1 & <0.1 & 13 & 14 & 216 & 38 & 45 & 44 & <10 & 8 & <10 & 304 & 606 & <5 & 23 & <10 & 746\end{array}$ $\begin{array}{llllllllllllllllll}<0.1 & <0.1 & <0.1 & <5 & <5 & 62 & 19 & 188 & <5 & <10 & <5 & <10 & 11 & 74 & <5 & 25 & <10 & 143\end{array}$ $\begin{array}{llllllllllllllllll}<.1 & <0.1 & <0.1 & <5 & <5 & 19 & <5 & 214 & <5 & <10 & 5 & <10 & <10 & 544 & <5 & 49 & <10 & 49\end{array}$ $\begin{array}{llllllllllllllllll}<0.1 & <0.1 & <0.1 & <5 & <5 & 97 & 23 & 189 & <5 & <10 & <5 & <10 & 14 & 92 & <5 & 21 & <10 & 173\end{array}$ $\begin{array}{llllllllllllllllll}0.24 & <0.1 & <0.1 & <5 & 9 & 114 & 28 & 222 & <5 & <10 & <5 & <10 & 187 & 266 & <5 & 41 & <10 & 101\end{array}$ $\begin{array}{llllllllllllllllll}<0.1 & <0.1 & <0.1 & <5 & <5 & 65 & 14 & 159 & 5 & <10 & <5 & <10 & 23 & 55 & <5 & 18 & <10 & 208\end{array}$ $\begin{array}{lllllllllllllll}<10 & <10 & 13 & 48 & <10 & <5 & <15 & <5 & 98 & 64 & 33 & 35 & <10 & <10 & 12\end{array}$ $\begin{array}{lllllllllllllll}<10 & <10 & <10 & 42 & <10 & <5 & <15 & 7 & 22 & 10 & 11 & 33 & <10 & <10 & <10\end{array}$ $\begin{array}{lllllllllllllll}<10 & <10 & <10 & 35 & <10 & <5 & <15 & 7 & 43 & 30 & 22 & 34 & <10 & <10 & <10\end{array}$ $\begin{array}{lllllllllllllll}<10 & <10 & 22 & 27 & <10 & 10 & <15 & 5 & 165 & 94 & 61 & 39 & <10 & <10 & 18\end{array}$ $\begin{array}{lllllllllllllll}<10 & <10 & <10 & 38 & <10 & <5 & <15 & 5 & 36 & 31 & 19 & 32 & <10 & <10 & <10\end{array}$ $\begin{array}{lllllllllllllll}<10 & <10 & 11 & 54 & <10 & 5 & <15 & 29 & 30 & 12 & 27 & 20 & <10 & 10 & <10\end{array}$ $\begin{array}{lllllllllllllll}<10 & 10 & 16 & 15 & <10 & <5 & <15 & <5 & 176 & 117 & 76 & 41 & <10 & <10 & 21\end{array}$ $\begin{array}{lllllllllllllll}<10 & <10 & <10 & 67 & <10 & <5 & <15 & 16 & 13 & <10 & 11 & 25 & <10 & <10 & <10\end{array}$ $\begin{array}{lllllllllllllll}<10 & <10 & <10 & 105 & 17 & 9 & <15 & 50 & <10 & <10 & <10 & 16 & <10 & <10 & <10\end{array}$ $\begin{array}{lllllllllllllll}<10 & <10 & 10 & 17 & 18 & 18 & <15 & 7 & 18 & 19 & <10 & 47 & <10 & <10 & <10\end{array}$

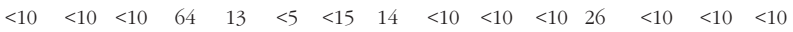
$\begin{array}{lllllllllllllll}<10 & <10 & 12 & 97 & 44 & <5 & <15 & 48 & <10 & <10 & <10 & 23 & <10 & 17 & <10\end{array}$ $\begin{array}{lllllllllllllll}<10 & 12 & <10 & 44 & 17 & <5 & <15 & 7 & 17 & 11 & <10 & 32 & <10 & <10 & <10\end{array}$ $\begin{array}{lllllllllllllll}<10 & <10 & 15 & 112 & 82 & 142 & <15 & 61 & <10 & 11 & 21 & 15 & <10 & 12 & <10\end{array}$ \begin{tabular}{lllllllllllllll}
$<10$ & $<10$ & $<10$ & 53 & $<10$ & $<5$ & $<15$ & 11 & $<10$ & 10 & $<10$ & 32 & $<10$ & $<10$ & $<10$ \\
\hline
\end{tabular} 


\begin{tabular}{|c|c|c|c|c|c|c|c|c|c|c|c|c|c|c|c|c|c|c|}
\hline Sample & UTM, $\mathbf{E}$ & UTM, $\mathbf{N}$ & Zone & Field name & Tectonic Unit & $\mathrm{SiO}_{2}$ & $\mathrm{TiO}_{2}$ & $\mathrm{Al}_{2} \mathrm{O}_{3}$ & $\mathrm{Fe}_{2} \mathrm{O}_{3}$ & FeOt & MgO & $\mathrm{CaO}$ & $\mathrm{Na}_{2} \mathrm{O}$ & $\mathbf{K}_{2} \mathrm{O}$ & MnO & $\mathbf{P}_{2} \mathrm{O}_{5}$ & Gl.tap & SuM \\
\hline 38442 & 468044 & 8605158 & 37 & Silisified metagabbro & Xixano Complex & 41.46 & 1.24 & 16.00 & 12.48 & 11.23 & 5.07 & 16.57 & 1.19 & 0.17 & 0.16 & 0.11 & 3.71 & 98.15 \\
\hline 40752 & 468780 & 8732418 & 37 & Quartz-feldspar gneiss & Xixano Complex & 77.35 & 0.12 & 11.66 & 1.48 & 1.33 & 0.02 & 0.49 & 2.81 & 5.22 & 0.02 & 0.02 & 0.24 & 99.43 \\
\hline 38411 & 472925 & 8731708 & 37 & Diorite & Xixano Complex & 57.78 & 0.72 & 16.15 & 7.97 & 7.17 & 4.28 & 7.30 & 2.76 & 1.13 & 0.14 & 0.18 & 0.45 & 98.84 \\
\hline 33338 & 473318 & 8606276 & 37 & Intermediate metavolcanite? & Xixano Complex & 51.67 & 0.64 & 17.37 & 10.66 & 9.59 & 5.43 & 9.66 & 3.08 & 0.28 & 0.19 & 0.11 & 0.02 & 99.09 \\
\hline 33417 & 475693 & 8574100 & 37 & Tonalite & Xixano Complex & 72.65 & 0.12 & 14.86 & 0.87 & 0.78 & 0.20 & 1.46 & 4.26 & 3.64 & 0.02 & 0.03 & 0.16 & 98.28 \\
\hline 33420 & 476043 & 8528294 & 37 & Granitic gneiss & Xixano Complex & 73.78 & 0.27 & 11.59 & 3.51 & 3.16 & 0.06 & 0.20 & 4.13 & 4.70 & 0.06 & 0.03 & 0.03 & 98.38 \\
\hline 33215 & 478212 & 8542704 & 37 & Tonalite, mus/bio & Xixano Complex & 73.33 & 0.11 & 15.06 & 0.32 & 0.29 & 0.15 & 0.99 & 3.54 & 4.61 & 0.02 & 0.03 & 0.47 & 98.65 \\
\hline 33216 & 478217 & 8543012 & 37 & Graphite schist/gneiss & Xixano Complex & 70.73 & 0.258 & 5.29 & 0.547 & 0.49 & 0.21 & 0.04 & $<0.1$ & 1.516 & 0.018 & 0.015 & 20.65 & 99.35 \\
\hline 33337 & 479899 & 8607586 & 37 & Ferruginous quartzite & Xixano Complex & 42.53 & 0.16 & 16.68 & 13.60 & 12.24 & 1.64 & 9.83 & 0.10 & 0.05 & 12.56 & 0.34 & -0.28 & 97.20 \\
\hline 33336 & 480501 & 8608718 & 37 & Metasediment & Xixano Complex & 54.87 & 0.52 & 11.73 & 5.10 & 4.59 & 5.73 & 15.32 & 2.92 & 1.73 & 0.18 & 0.11 & 0.91 & 99.12 \\
\hline 33414 & 495263 & 8476986 & 37 & Amphibolite & Xixano Complex & 47.36 & 0.24 & 15.55 & 7.67 & 6.90 & 10.20 & 16.27 & 0.68 & 0.06 & 0.15 & $<0.01$ & 0.38 & 98.58 \\
\hline 33429 & 496853 & 8525208 & 37 & Metadiabas & Xixano Complex & 44.65 & 0.74 & 16.35 & 11.20 & 10.08 & 4.29 & 19.86 & 0.57 & 0.31 & 0.21 & 0.20 & 1.04 & 99.43 \\
\hline 33430 & 498017 & 8524454 & 37 & Granitic orthogneiss & Xixano Complex & 73.92 & 0.13 & 13.71 & 1.33 & 1.20 & 0.18 & 1.21 & 3.41 & 4.66 & 0.02 & 0.04 & 0.22 & 98.82 \\
\hline 33431 & 502408 & 8520338 & 37 & Orthopyroxene.bearing metagabbro & Xixano Complex & 50.37 & 1.06 & 9.58 & 8.24 & 7.42 & 10.57 & 15.53 & 1.90 & 0.38 & 0.16 & 0.16 & 0.56 & 98.51 \\
\hline 40652 & 503236 & 8734434 & 37 & Amphibolite & Xixano Complex & 47.84 & 1.06 & 14.29 & 13.04 & 11.74 & 8.06 & 11.87 & 1.31 & 0.18 & 0.20 & 0.09 & 0.54 & 98.47 \\
\hline 40748 & 508748 & 8752896 & 37 & Amphibolitic gneiss & Xixano Complex & 43.19 & 0.70 & 18.73 & 14.45 & 13.01 & 6.17 & 13.21 & 1.32 & 0.52 & 0.21 & 0.02 & 0.59 & 99.11 \\
\hline 40747 & 510296 & 8752896 & 37 & Marble & Xixano Complex & 2.23 & 0.01 & 0.00 & 0.07 & 0.06 & 19.00 & 33.34 & $<0.1$ & 0.015 & 0.005 & 0.06 & & \\
\hline 40663 & 513384 & 8741392 & 37 & Granitic gneiss & Xixano Complex & 68.79 & 0.41 & 14.95 & 2.65 & 2.39 & 0.42 & 1.68 & 3.41 & 5.29 & 0.03 & 0.11 & 0.90 & 98.65 \\
\hline 40662 & 514560 & 8747978 & 37 & Marble & Xixano Complex & 14.26 & 0.00 & 0.00 & 0.07 & 0.06 & 11.81 & 37.57 & $<0.1$ & 0.013 & 0.013 & 0.15 & & \\
\hline 40746 & 517936 & 8753162 & 37 & Granite & Xixano Complex & 73.03 & 0.15 & 14.18 & 1.33 & 1.20 & 0.22 & 1.12 & 3.59 & 4.88 & 0.02 & 0.06 & 0.68 & 99.28 \\
\hline 40664 & 520875 & 8729630 & 37 & Tonalitic gneiss & Xixano Complex & 48.11 & 0.71 & 22.79 & 5.20 & 4.68 & 2.86 & 13.73 & 2.91 & 0.49 & 0.14 & 0.10 & 1.33 & 98.37 \\
\hline 40653 & 523577 & 8751122 & 37 & Marble & Xixano Complex & 7.58 & 0.01 & 0.00 & 0.07 & 0.06 & 8.22 & 44.32 & $<0.1$ & 0.038 & 0.020 & 0.17 & & \\
\hline 40745 & 523662 & 8754440 & 37 & Amphibolitic gneiss & Xixano Complex & 41.29 & 1.43 & 19.72 & 11.24 & 10.12 & 3.74 & 20.74 & 0.28 & 0.28 & 0.18 & 0.19 & 0.29 & 99.38 \\
\hline 33259 & 435294 & 8518053 & 37 & amphibolite & Xixano Complex & 39.78 & 1.19 & 16.61 & 16.02 & 14.42 & 7.85 & 13.64 & 1.74 & 0.38 & 0.22 & 0.10 & 1.07 & 98.59 \\
\hline 33258 & 435426 & 8518300 & 37 & amphibolite & Xixano Complex & 48.38 & 0.64 & 14.87 & 12.39 & 11.15 & 8.86 & 13.34 & 0.92 & 0.04 & 0.19 & 0.05 & -0.02 & 99.65 \\
\hline 33275 & 443652 & 8539964 & 37 & granulite & Xixano Complex & 72.08 & 0.29 & 11.89 & 6.07 & 5.46 & 0.82 & 3.43 & 3.06 & 0.38 & 0.12 & 0.05 & 0.20 & 98.40 \\
\hline 33274 & 443739 & 8539932 & 37 & Grt granulite & Xixano Complex & 70.47 & 0.56 & 12.62 & 6.12 & 5.51 & 1.15 & 1.96 & 4.34 & 0.77 & 0.16 & 0.02 & 0.49 & 98.66 \\
\hline 33276 & 444146 & 8543073 & 37 & Graphite gneiss & Xixano Complex & 71.46 & 0.66 & 10.82 & 3.07 & 2.76 & 0.40 & 0.16 & 0.56 & 2.21 & $<0.01$ & 0.04 & 9.34 & 98.72 \\
\hline 33348 & 461810 & 8512658 & 37 & Granite & Xixano Complex & 71.70 & 0.21 & 14.30 & 1.55 & 1.40 & 0.21 & 1.12 & 3.99 & 4.61 & 0.06 & 0.05 & 0.30 & 98.10 \\
\hline 33347 & 467131 & 8520606 & 37 & Felsic metavolcanite & Xixano Complex & 74.57 & 0.16 & 11.78 & 2.53 & 2.28 & 0.07 & 0.38 & 4.23 & 3.64 & 0.01 & 0.02 & 0.34 & 97.72 \\
\hline 33355 & 471365 & 8512334 & 37 & Amphibolite & Xixano Complex & 48.45 & 2.53 & 12.13 & 15.78 & 14.20 & 5.86 & 10.54 & 2.09 & 0.15 & 0.25 & 0.20 & 0.69 & 98.66 \\
\hline 33273 & 473075 & 8542389 & 37 & Quartzofeldspathic gneiss & Xixano Complex & 75.18 & 0.13 & 11.43 & 1.27 & 1.14 & 0.05 & 0.04 & 0.36 & 9.59 & $<0.01$ & 0.03 & 0.46 & 98.55 \\
\hline 31952 & 215070 & 8602610 & 37 & Granitic gneiss with quartz rich bands & Muaquia Complex & 87.92 & 0.02 & 5.71 & 0.61 & 0.55 & 0.01 & 0.01 & 2.23 & 1.84 & 0.02 & 0.01 & 0.34 & 98.73 \\
\hline 31999 & 227601 & 8572845 & 37 & Biotite-paragneiss & Muaquia Complex & 74.49 & 0.29 & 13.30 & 1.32 & 1.19 & 0.47 & 0.23 & 3.85 & 4.30 & 0.01 & 0.04 & 0.78 & 99.08 \\
\hline 32000 & 227814 & 8575975 & 37 & Kyanite-quartzite & Muaquia Complex & 59.90 & 0.56 & 35.87 & 1.74 & 1.57 & 0.14 & 0.04 & $<0.1$ & 0.19 & $<0.01$ & 0.16 & 0.62 & 99.22 \\
\hline 31980 & 228310 & 8572518 & 37 & Kyanite-muscovite-garnet-quartzite & Muaquia Complex & 71.38 & 1.84 & 24.79 & 0.38 & 0.34 & 0.11 & 0.02 & $<0.1$ & 0.02 & 0.01 & 0.10 & 0.23 & 98.92 \\
\hline 31836 & 243905 & 8627086 & 37 & Biotite gneiss & Muaquia Complex & 70.30 & 0.32 & 15.47 & 2.38 & 2.14 & 0.76 & 2.43 & 4.43 & 2.87 & 0.06 & 0.11 & 0.48 & 99.61 \\
\hline 34283 & 260955 & 8518266 & 37 & Granitic gneiss & Muaquia Complex & 71.21 & 0.55 & 13.35 & 3.55 & 3.20 & 0.62 & 0.51 & 4.88 & 3.72 & 0.01 & 0.10 & 0.24 & 98.75 \\
\hline 34276 & 268760 & 8515792 & 37 & Granitic gneiss & Muaquia Complex & 75.52 & 0.24 & 12.25 & 1.77 & 1.59 & 0.38 & 0.14 & 4.39 & 3.37 & $<0.01$ & 0.05 & 0.35 & 98.46 \\
\hline 34278 & 279870 & 8518225 & 37 & Granitic gneiss & Muaquia Complex & 72.50 & 0.20 & 14.34 & 1.49 & 1.34 & 0.21 & 0.99 & 4.44 & 3.89 & 0.03 & 0.03 & 0.36 & 98.47 \\
\hline 36056 & 289779 & 8549678 & 37 & Pyroxenite & Muaquia Complex & 48.00 & 0.66 & 8.83 & 10.05 & 9.05 & 14.03 & 14.72 & 1.09 & 0.28 & 0.18 & 0.04 & 0.59 & 98.47 \\
\hline 36059 & 290009 & 8552672 & 37 & Enderbite? & Muaquia Complex & 44.93 & 0.09 & 24.23 & 4.98 & 4.48 & 8.26 & 15.77 & 0.94 & 0.14 & 0.08 & 0.01 & 0.56 & 99.99 \\
\hline 37262 & 303868 & 8567982 & 37 & Amphibolite & Muaquia Complex & 66.62 & 0.59 & 14.36 & 4.58 & 4.12 & 1.97 & 2.16 & 4.19 & 1.73 & 0.04 & 0.15 & 2.36 & 98.75 \\
\hline 38412 & 314057 & 8545036 & 37 & Granite & Muaquia Complex & 78.26 & 0.15 & 11.96 & 1.39 & 1.25 & 0.11 & 1.52 & 5.88 & 0.11 & 0.02 & 0.02 & 0.16 & 99.58 \\
\hline 33255 & 332105 & 8564327 & 37 & amphibolite & Muaquia Complex & 49.72 & 0.89 & 18.87 & 7.99 & 7.19 & 4.84 & 12.17 & 3.31 & 0.33 & 0.11 & 0.03 & 0.59 & 98.85 \\
\hline 33256 & 332105 & 8564327 & 37 & amphibolite & Muaquia Complex & 55.81 & 0.41 & 16.09 & 4.04 & 3.64 & 5.07 & 12.44 & 4.40 & 0.21 & 0.11 & 0.03 & 0.26 & 98.87 \\
\hline 33257 & 325810 & 8578127 & 37 & granitic-gneiss & Muaquia Complex & 66.39 & 0.47 & 16.48 & 2.87 & 2.58 & 0.79 & 2.47 & 4.68 & 3.53 & 0.06 & 0.12 & 0.34 & 98.19 \\
\hline 31796 & 241388 & 8606286 & 37 & mafic granulitic gneiss & M'Sawize Complex & 53.48 & 0.90 & 17.79 & 9.17 & 8.25 & 4.18 & 8.12 & 4.09 & 1.16 & 0.19 & 0.17 & 0.02 & 99.26 \\
\hline 37246 & 246484 & 8545976 & 37 & Metagabbro & M'Sawize Complex & 63.52 & 0.77 & 12.64 & 5.22 & 4.70 & 3.75 & 7.34 & 4.38 & 0.43 & 0.06 & 0.07 & 0.31 & 98.49 \\
\hline 31978 & 248255 & 8588574 & 37 & Tonalite & M'Sawize Complex & 59.46 & 0.39 & 16.67 & 3.34 & 3.01 & 3.47 & 8.89 & 6.34 & 0.42 & 0.05 & 0.01 & 0.13 & 99.16 \\
\hline 37245 & 249453 & 8548646 & 37 & Metagabbro & M'Sawize Complex & 56.94 & 0.72 & 11.09 & 16.03 & 14.43 & 4.50 & 7.52 & 2.02 & 0.32 & 0.21 & 0.15 & -0.25 & 99.26 \\
\hline 37244 & 249779 & 8549028 & 37 & Microgabbro & M'Sawize Complex & 49.46 & 0.59 & 16.60 & 10.06 & 9.05 & 7.60 & 12.13 & 1.88 & 0.39 & 0.16 & 0.07 & 0.51 & 99.46 \\
\hline 37243 & 249874 & 8549332 & 37 & Metagabbro & M'Sawize Complex & 45.04 & 1.05 & 13.36 & 15.76 & 14.18 & 8.22 & 10.54 & 2.42 & 0.75 & 0.17 & 0.11 & 0.63 & 98.03 \\
\hline 36073 & 527463 & 8599738 & 37 & Intermediate dyke? & Lalamo Complex & 48.52 & 0.33 & 18.02 & 7.79 & 7.01 & 9.54 & 11.63 & 2.25 & 0.15 & 0.13 & 0.01 & 0.02 & 98.41 \\
\hline 38430 & 551032 & 8568752 & 37 & Tonalitic gneiss & Lalamo Complex & 67.24 & 0.46 & 16.64 & 3.02 & 2.72 & 1.47 & 3.49 & 4.56 & 2.08 & 0.05 & 0.13 & 0.32 & 99.47 \\
\hline 40787 & 553182 & 8685354 & 37 & Arenitic paragneiss & Lalamo Complex & 75.73 & 0.20 & 11.77 & 1.99 & 1.79 & 0.03 & 0.62 & 2.97 & 4.99 & 0.03 & 0.01 & 0.23 & 98.56 \\
\hline 40790 & 555366 & 8692462 & 37 & Arenite & Lalamo Complex & 76.27 & 0.13 & 11.38 & 0.98 & 0.88 & $<0.01$ & 0.21 & 2.75 & 5.54 & $<0.01$ & 0.02 & 1.15 & 98.43 \\
\hline 40788 & 555479 & 8692850 & 37 & Arenite & Lalamo Complex & 78.10 & 0.14 & 10.48 & 1.02 & 0.92 & $<0.01$ & 0.09 & 2.93 & 4.87 & $<0.01$ & 0.01 & 1.02 & 98.66 \\
\hline 40789 & 555479 & 8692850 & 37 & Arenite & Lalamo Complex & 79.23 & 0.12 & 10.35 & 1.37 & 1.23 & $<0.01$ & 0.19 & 3.51 & 3.50 & $<0.01$ & $<0.01$ & 0.96 & 99.24 \\
\hline 40655 & 557468 & 8707216 & 37 & Grey gneiss & Lalamo Complex & 73.75 & 0.37 & 11.85 & 3.48 & 3.13 & 0.12 & 1.21 & 3.08 & 4.18 & 0.08 & 0.08 & 0.51 & 98.70 \\
\hline 33233 & 560409 & 8561078 & 37 & Tonalitic gneiss & Lalamo Complex & 69.90 & 0.56 & 14.33 & 3.94 & 3.55 & 0.76 & 2.17 & 3.16 & 3.43 & 0.07 & 0.17 & 0.34 & 98.82 \\
\hline 40667 & 562796 & 8647918 & 37 & Granodioritic gneiss & Lalamo Complex & 71.29 & 0.32 & 14.02 & 2.57 & 2.31 & 0.49 & 1.64 & 4.12 & 3.36 & 0.03 & 0.09 & 0.21 & 98.14 \\
\hline 40756 & 565363 & 8668830 & 37 & Amphibolite & Lalamo Complex & 58.70 & 0.37 & 11.27 & 4.66 & 4.19 & 5.97 & 14.23 & 0.34 & 1.65 & 0.24 & 0.07 & 2.14 & 99.65 \\
\hline 40666 & 567810 & 8643328 & 37 & Marble & Lalamo Complex & 6.07 & 0.00 & 0.00 & 0.03 & 0.03 & 3.51 & 49.34 & $<0.1$ & 0.037 & 0.002 & 0.07 & & \\
\hline 40753 & 568148 & 8672756 & 37 & Quartzitic gneiss & Lalamo Complex & 74.84 & 0.18 & 12.45 & 1.11 & 1.00 & 0.02 & 0.29 & 3.64 & 5.17 & $<0.01$ & 0.02 & 0.97 & 98.69 \\
\hline 40670 & 573236 & 8656464 & 37 & Marble & Lalamo Complex & 1.76 & 0.00 & 0.00 & 0.08 & 0.07 & 35.78 & 14.28 & $<0.1$ & 0.003 & 0.009 & 0.02 & & \\
\hline
\end{tabular}




$\begin{array}{llllllllllllllllllllllllllllllllllll}\mathbf{S} & \mathbf{C l} & \mathbf{F} & \mathbf{M o} & \mathbf{N b} & \mathbf{Z r} & \mathbf{Y} & \mathbf{S r} & \mathbf{R b} & \mathbf{U} & \mathbf{T h} & \mathbf{P b} & \mathbf{C r} & \mathbf{V} & \mathbf{A s} & \mathbf{S c} & \mathbf{H f} & \mathbf{B a} & \mathbf{S b} & \mathbf{S n} & \mathbf{G a} & \mathbf{Z n} & \mathbf{C u} & \mathbf{N i} & \mathbf{Y b} & \mathbf{C o} & \mathbf{C e} & \mathbf{L a} & \mathbf{N d} & \mathbf{W} & \mathbf{C s} & \mathbf{T a} & \mathbf{P r} \\ 4.10 & <0.1 & <0.1 & <5 & 7 & 86 & 22 & 240 & <5 & <10 & <5 & 13 & 123 & 204 & <5 & 35 & <10 & 129 & <10 & 12 & 17 & 125 & 36 & 39 & <15 & 50 & <10 & 10 & <10 & 13 & <10 & 16 & <10\end{array}$

$\begin{array}{ccccccccccccccccccccccccccccccccc}<0.1 & <0.1 & <0.1 & <5 & <5 & 180 & 10 & 56 & 57 & <10 & 13 & 10 & <10 & <10 & 6 & <10 & <10 & 1304 & <10 & <10 & <10 & 32 & 11 & <5 & <15 & 6 & 60 & 28 & 19 & 28 & <10 & <10 & 12\end{array}$

$\begin{array}{llllllllllllllllllllllllllllllllllllllllll}<0.1 & <0.1 & <0.1 & <5 & 6 & 103 & 26 & 276 & 34 & <10 & 5 & <10 & 54 & 153 & <5 & 28 & <10 & 386 & <10 & <10 & 10 & 82 & 14 & 11 & <15 & 21 & 50 & 16 & 21 & 28 & <10 & <10 & <10\end{array}$ $\begin{array}{lllllllllllllllllllllllllllllllllllllllllll}<0.1 & <0.1 & <0.1 & <5 & 5 & 71 & 20 & 269 & <5 & <10 & <5 & <10 & 56 & 213 & <5 & 38 & <10 & 101 & <10 & 10 & 14 & 84 & 23 & 8 & <15 & 34 & <10 & <10 & <10 & 25 & <10 & 12 & 10\end{array}$ $\begin{array}{llllllllllllllllllllllllllllllllllllllllll}<.1 & <0.1 & <0.1 & <5 & <5 & 72 & 10 & 878 & 91 & <10 & <5 & 26 & 20 & <10 & <5 & <10 & <10 & 1327 & <10 & <10 & 14 & 42 & <10 & <5 & <15 & <5 & 18 & 23 & <10 & 39 & <10 & <10 & <10\end{array}$

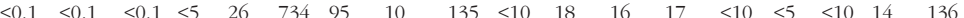
$\begin{array}{llllllllllllllllll}<0.1 & <0.1 & <0.1 & <5 & 6 & 54 & 12 & 394 & 96 & <10 & 7 & 40 & 11 & <10 & <5 & <10 & <10 & 2050\end{array}$ $\begin{array}{llllllllllllllllll}<0.1 & <0.1 & <0.1 & 15 & <5 & 94 & 36 & 10 & 42 & <10 & 7 & <10 & 601 & 1138 & <5 & 15 & <10 & 637\end{array}$ $\begin{array}{llllllllllllllllll}<0.1 & <0.1 & 1.08 & <5 & 5 & 133 & 46 & 11 & 5 & <10 & 5 & <10 & 214 & 253 & <5 & 16 & <10 & 70\end{array}$ $\begin{array}{llllllllllllllllll}<0.1 & <0.1 & <0.1 & <5 & 16 & 264 & 57 & 162 & 53 & <10 & 13 & 15 & 55 & 56 & <5 & 20 & <10 & 442\end{array}$ $\begin{array}{cccccccccccccccccc}<0.1 & <0.1 & 0.15 & <5 & <5 & 17 & 6 & 362 & <5 & <10 & <5 & <10 & 374 & 141 & 6 & 62 & <10 & 101\end{array}$ $\begin{array}{llllllllllllllllll}<0.1 & <0.1 & 0.4 & 39 & <5 & 48 & 16 & 203 & 5 & <10 & <5 & <10 & 290 & 230 & 5 & 42 & <10 & 479\end{array}$ $\begin{array}{llllllllllllllllll}<0.1 & <0.1 & <0.1 & <5 & 7 & 142 & 25 & 158 & 145 & <10 & 20 & 27 & 11 & 13 & <5 & <10 & <10 & 1315\end{array}$ $\begin{array}{llllllllllllllllll}<0.1 & <0.1 & 0.26 & <5 & 8 & 84 & 34 & 382 & <5 & <10 & <5 & <10 & 438 & 227 & <5 & 68 & <10 & 172\end{array}$ $\begin{array}{llllllllllllllllll}0.10 & 0.16 & <0.1 & <5 & 5 & 58 & 26 & 117 & 6 & <10 & 5 & <10 & 332 & 294 & <5 & 50 & <10 & 54\end{array}$ $\begin{array}{llllllllllllllllll}<0.1 & <0.1 & <0.1 & <5 & <5 & 21 & 6 & 379 & 5 & <10 & <5 & <10 & 45 & 613 & <5 & 48 & <10 & 137\end{array}$ $\begin{array}{llllllllllllllllll}<0.1 & <0.1 & <0.1 & <5 & <5 & 17 & <5 & 75 & <5 & <10 & 5 & <10 & <10 & <10 & <5 & 32 & <10 & 39\end{array}$ $\begin{array}{llllllllllllllllll}<0.1 & <0.1 & <0.1 & <5 & 18 & 313 & 27 & 161 & 168 & <10 & 31 & 22 & 20 & 16 & <5 & <10 & 15 & 939\end{array}$ $\begin{array}{llllllllllllllllll}0.43 & <0.1 & <0.1 & <5 & <5 & 23 & 9 & 62 & 6 & <10 & 6 & 2262 & 12 & <10 & <5 & 35 & <10 & 35\end{array}$ $\begin{array}{llllllllllllllllll}<0.1 & <0.1 & <0.1 & <5 & 7 & 176 & <5 & 195 & 177 & <10 & 66 & 35 & 20 & 10 & <5 & <10 & <10 & 943\end{array}$ $\begin{array}{llllllllllllllllll}<0.1 & <0.1 & <0.1 & <5 & 5 & 119 & 25 & 484 & 6 & <10 & 8 & 20 & 234 & 113 & <5 & 30 & <10 & 174\end{array}$

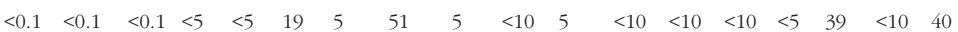
$\begin{array}{llllllllllllllllll}<0.1 & <0.1 & <0.1 & <5 & 6 & 178 & 44 & 1973 & 5 & <10 & 5 & <10 & 245 & 186 & <5 & 41 & <10 & 52\end{array}$ $\begin{array}{llllllllllllllllll}<0.1 & 0.40 & 0.64 & <5 & 5 & 33 & 25 & 514 & <5 & <10 & <5 & 12 & 108 & 425 & 7 & 50 & <10 & 148\end{array}$

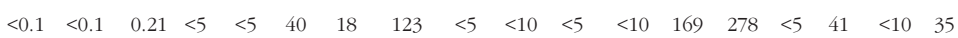
$\begin{array}{llllllllllllllllll}<0.1 & <0.1 & <0.1 & <5 & <5 & 220 & 90 & 146 & <5 & <10 & 7 & <10 & <10 & <10 & <5 & 18 & <10 & 176\end{array}$ $\begin{array}{llllllllllllllllll}<0.1 & <0.1 & <0.1 & <5 & 9 & 211 & 39 & 115 & <5 & <10 & <5 & <10 & 19 & <10 & <5 & 12 & <10 & 357\end{array}$ $\begin{array}{llllllllllllllllll}<0.1 & <0.1 & <0.1 & 43 & 17 & 171 & 11 & 92 & 88 & <10 & 5 & <10 & 206 & 1738 & 6 & <10 & <10 & 1888\end{array}$ $\begin{array}{llllllllllllllllll}<0.1 & <0.1 & 0.1 & 5 & 26 & 168 & 69 & 122 & 253 & 13 & 31 & 30 & 14 & 13 & <5 & <10 & <10 & 580\end{array}$ $\begin{array}{llllllllllllllllll}<0.1 & <0.1 & <0.1 & <5 & 34 & 351 & 186 & 29 & 44 & <10 & 15 & <10 & 19 & <10 & <5 & <10 & <10 & 1149\end{array}$ $\begin{array}{llllllllllllllllll}<0.1 & <0.1 & 0.45 & <5 & 6 & 146 & 54 & 188 & <5 & <10 & <5 & <10 & 52 & 441 & <5 & 54 & 11 & 111\end{array}$ $\begin{array}{llllllllllllllllll}<0.1 & <0.1 & 0.18 & <5 & 34 & 276 & 61 & 22 & 210 & <10 & 18 & 22 & 11 & <10 & 64 & <10 & <10 & 1017\end{array}$ $\begin{array}{lllllllllllllll}<10 & <10 & 19 & 115 & <10 & 5 & <15 & 5 & 143 & 98 & 69 & 31 & <10 & <10 & 16\end{array}$ $\begin{array}{lllllllllllllll}<10 & <10 & 15 & 59 & <10 & <5 & <15 & <5 & 17 & 13 & <10 & 38 & <10 & <10 & <10\end{array}$ $\begin{array}{lllllllllllllll}<10 & <10 & <10 & 18 & 21 & 8 & <15 & 6 & <10 & 17 & <10 & 49 & <10 & <10 & <10\end{array}$ $\begin{array}{lllllllllllllll}<10 & <10 & 24 & 106 & <10 & 8 & 19 & 15 & 17 & <10 & <10 & <10 & <10 & 25 & 20\end{array}$ $\begin{array}{lllllllllllllll}<10 & <10 & 13 & 64 & 11 & 24 & <15 & 8 & 64 & 36 & 36 & 25 & <10 & <10 & 11\end{array}$ $\begin{array}{lllllllllllllll}<10 & <10 & <10 & 51 & <10 & 63 & <15 & 33 & <10 & <10 & <10 & 28 & <10 & <10 & <10\end{array}$ $\begin{array}{lllllllllllllll}<10 & <10 & 16 & 73 & 28 & 106 & <15 & 47 & 21 & <10 & 14 & <10 & <10 & 12 & <10\end{array}$ $\begin{array}{lllllllllllllll}<10 & <10 & 11 & 35 & <10 & <5 & <15 & <5 & 52 & 38 & 22 & 33 & <10 & <10 & <10\end{array}$ $\begin{array}{lllllllllllllll}<10 & <10 & <10 & 74 & <10 & 100 & <15 & 35 & 47 & 109 & 73 & 17 & <10 & 11 & 23\end{array}$ $\begin{array}{lllllllllllllll}<10 & <10 & <10 & 97 & 52 & 61 & <15 & 59 & <10 & <10 & <10 & <10 & <10 & <10 & 10\end{array}$ $\begin{array}{lllllllllllllll}<10 & <10 & 16 & 82 & 124 & <5 & <15 & 54 & <10 & <10 & <10 & <10 & <10 & 13 & 14\end{array}$

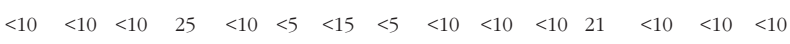
$\begin{array}{lllllllllllllll}<10 & <10 & 17 & 60 & 12 & <5 & <15 & 9 & 146 & 98 & 60 & 22 & <10 & <10 & 17\end{array}$

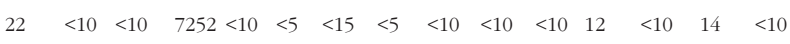
$\begin{array}{lllllllllllllll}<10 & <10 & 10 & 34 & 14 & <5 & <15 & 6 & 128 & 91 & 31 & 28 & <10 & <10 & 12\end{array}$ $\begin{array}{lllllllllllllll}<10 & <10 & 18 & 104 & 14 & 65 & <15 & 27 & <10 & <10 & 11 & 19 & <10 & <10 & <10\end{array}$ $\begin{array}{lllllllllllllll}<10 & <10 & <10 & 39 & <10 & <5 & <15 & <5 & <10 & <10 & <10 & <10 & <10 & <10 & <10\end{array}$ $\begin{array}{lllllllllllllll}<10 & <10 & 21 & 30 & 12 & 19 & <15 & 21 & 49 & 20 & 31 & <10 & <10 & 12 & 17\end{array}$ $\begin{array}{lllllllllllllll}13 & <10 & 13 & 96 & <10 & 217 & <15 & 83 & <10 & <10 & 16 & <10 & <10 & 11 & <10\end{array}$ $\begin{array}{lllllllllllllll}<10 & <10 & <10 & 67 & <10 & 66 & <15 & 50 & <10 & <10 & 13 & 11 & <10 & 11 & <10\end{array}$ $\begin{array}{lllllllllllllll}<10 & <10 & 15 & 95 & <10 & <5 & <15 & 7 & 36 & 16 & 26 & 36 & <10 & <10 & <10\end{array}$ $\begin{array}{lllllllllllllll}<10 & <10 & 17 & 100 & 10 & <5 & <15 & 10 & <10 & <10 & <10 & 32 & <10 & <10 & <10\end{array}$

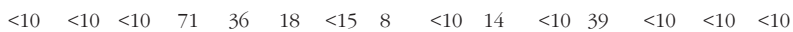
$\begin{array}{lllllllllllllll}<10 & <10 & 13 & 64 & <10 & <5 & <15 & <5 & 98 & 86 & 51 & 39 & <10 & <10 & 18\end{array}$ $\begin{array}{lllllllllllllll}<10 & <10 & 23 & 20 & <10 & 9 & <15 & 5 & 191 & 113 & 107 & 45 & <10 & <10 & 24\end{array}$ $\begin{array}{lllllllllllllll}<10 & <10 & 12 & 115 & 13 & 24 & <15 & 58 & 18 & 17 & 25 & <10 & <10 & 16 & <10\end{array}$ $\begin{array}{llllllllllllllllll}<0.1 & <0.1 & <0.1 & <5 & 17 & 474 & 5 & <5 & 71 & <10 & 10 & <10 & 13 & <10 & <5 & <10 & <10 & <10\end{array}$ $\begin{array}{llllllllllllllllll}<0.1 & <0.1 & <0.1 & <5 & 14 & 148 & 17 & 79 & 104 & <10 & 20 & <10 & 27 & 13 & <5 & 11 & <10 & 919\end{array}$ $\begin{array}{llllllllllllllllll}<0.1 & <0.1 & <0.1 & <5 & 10 & 214 & 5 & 35 & <5 & <10 & 6 & <10 & 54 & 24 & <5 & <10 & <10 & 64\end{array}$ $\begin{array}{llllllllllllllllll}<0.1 & <0.1 & <0.1 & <5 & 21 & 684 & 10 & 32 & <5 & <10 & 7 & <10 & 73 & 47 & 143 & <10 & 18 & 107\end{array}$ $\begin{array}{llllllllllllllllll}<0.1 & <0.1 & <0.1 & <5 & 6 & 113 & 9 & 578 & 75 & <10 & 13 & 13 & 17 & 46 & <5 & 16 & <10 & 1092\end{array}$ $\begin{array}{llllllllllllllllll}<0.1 & <0.1 & <0.1 & 8 & 13 & 361 & 65 & 44 & 81 & <10 & 12 & <10 & 25 & 17 & <5 & 11 & <10 & 695\end{array}$ $\begin{array}{llllllllllllllllll}<.1 & <0.1 & <0.1 & <5 & 11 & 204 & 29 & 42 & 80 & <10 & 14 & <10 & 14 & <10 & <5 & <10 & <10 & 370\end{array}$ $\begin{array}{llllllllllllllllll}<0.1 & <0.1 & <0.1 & <5 & 8 & 160 & 12 & 258 & 92 & <10 & 9 & 24 & <10 & 16 & <5 & <10 & <10 & 988\end{array}$

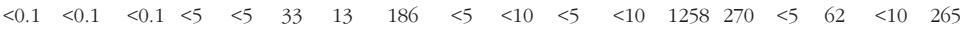
$\begin{array}{llllllllllllllllll}0.1 & 0.35 & <0.1 & <5 & <5 & 12 & <5 & 398 & <5 & <10 & <5 & <10 & 494 & 39 & 10 & 29 & <10 & 82\end{array}$

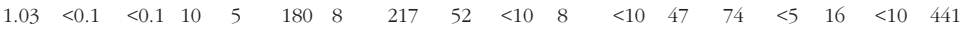

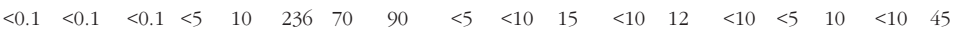
$\begin{array}{llllllllllllllllll}<.1 & <0.1 & 0.23 & <5 & <5 & 28 & 9 & 454 & 6 & <10 & <5 & <10 & 39 & 375 & <5 & 41 & <10 & 161\end{array}$ $\begin{array}{llllllllllllllllll}<0.1 & <0.1 & <0.1 & <5 & <5 & 40 & 13 & 419 & <5 & <10 & <5 & <10 & 149 & 143 & <5 & 39 & <10 & 148\end{array}$ $\begin{array}{llllllllllllllllll}<0.1 & <0.1 & <0.1 & <5 & 7 & 253 & 23 & 374 & 94 & <10 & 11 & <10 & 19 & 33 & <5 & <10 & <10 & 1138\end{array}$

$\begin{array}{llllllllllllllllll}<0.1 & <0.1 & <0.1 & <5 & 5 & 59 & 25 & 528 & 9 & <10 & 7 & <10 & 45 & 167 & <5 & 31 & <10 & 487\end{array}$ $\begin{array}{llllllllllllllllll}<0.1 & <0.1 & <0.1 & <5 & <5 & 77 & 32 & 341 & <5 & <10 & <5 & <10 & 21 & 102 & <5 & 45 & <10 & 153\end{array}$

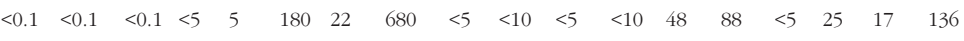
$\begin{array}{llllllllllllllllll}<0.1 & 0.14 & <0.1 & <5 & <5 & 80 & 22 & 250 & <5 & <10 & <5 & <10 & 22 & 247 & <5 & 21 & <10 & 150\end{array}$ $\begin{array}{llllllllllllllllll}<.1 & 0.15 & <0.1 & <5 & <5 & 41 & 13 & 265 & 10 & <10 & 6 & <10 & 188 & 243 & <5 & 46 & <10 & 455\end{array}$ $\begin{array}{llllllllllllllllll}0.10 & 0.44 & <0.1 & <5 & 6 & 33 & 33 & 182 & 13 & <10 & <5 & <10 & 125 & 385 & <5 & 53 & <10 & 223\end{array}$

$\begin{array}{llllllllllllllllll}<0.1 & <0.1 & <0.1 & <5 & <5 & 19 & 9 & 390 & <5 & <10 & <5 & <10 & 311 & 89 & 8 & 32 & <10 & 120\end{array}$ $\begin{array}{llllllllllllllllll}<.1 & <0.1 & <0.1 & <5 & 6 & 104 & 9 & 553 & 62 & <10 & 6 & 13 & 27 & 42 & <5 & 11 & <10 & 860\end{array}$ $\begin{array}{llllllllllllllllll}<0.1 & <0.1 & <0.1 & <5 & 23 & 750 & 53 & 30 & 87 & <10 & 11 & 12 & <10 & <10 & <5 & <10 & 88 & 1024\end{array}$ $\begin{array}{llllllllllllllllll}0.37 & <0.1 & <0.1 & <5 & 18 & 322 & 22 & 108 & 74 & <10 & 14 & 17 & 10 & <10 & <5 & <10 & <10 & 419\end{array}$ $\begin{array}{llllllllllllllllll}0.12 & <0.1 & <0.1 & <5 & 20 & 533 & 35 & 52 & 78 & <10 & 13 & 15 & <10 & <10 & <5 & <10 & 64 & 207\end{array}$ $\begin{array}{llllllllllllllllll}0.17 & <0.1 & <0.1 & <5 & 27 & 518 & 22 & 65 & 55 & <10 & 13 & 14 & <10 & <10 & <5 & <10 & 55 & 208\end{array}$ $\begin{array}{llllllllllllllllll}<0.1 & <0.1 & <0.1 & <5 & 12 & 403 & 77 & 100 & 74 & <10 & 16 & <10 & 13 & <10 & 5 & 20 & 32 & 1261\end{array}$ $\begin{array}{llllllllllllllllll}<0.1 & <0.1 & <0.1 & <5 & 10 & 209 & 37 & 237 & 128 & <10 & 16 & 16 & 27 & 32 & <5 & 12 & <10 & 1019\end{array}$ $\begin{array}{llllllllllllllllll}<0.1 & <0.1 & <0.1 & <5 & 7 & 183 & 13 & 286 & 63 & <10 & 12 & <10 & 89 & 23 & 5 & 10 & <10 & 1007\end{array}$ $\begin{array}{llllllllllllllllll}<0.1 & <0.1 & <0.1 & <5 & 17 & 161 & 29 & 333 & 48 & <10 & 14 & <10 & 54 & 47 & 6 & 22 & <10 & 477\end{array}$

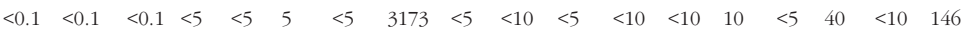
$\begin{array}{llllllllllllllllll}0.41 & <0.1 & <0.1 & <5 & 14 & 204 & 29 & 50 & 78 & <10 & 13 & 15 & <10 & <10 & <5 & <10 & <10 & 1621\end{array}$ $\begin{array}{llllllllllllllllll}<0.1 & <0.1 & <0.1 & <5 & <5 & 16 & <5 & 199 & <5 & <10 & 6 & <10 & <10 & <10 & 6 & 25 & <10 & 24\end{array}$ $\begin{array}{lllllllllllllll}<10 & <10 & 15 & 38 & <10 & <5 & <15 & <5 & <10 & <10 & <10 & 22 & <10 & <10 & <10\end{array}$ $\begin{array}{lllllllllllllll}<10 & <10 & 10 & 16 & 10 & 7 & <15 & 6 & <10 & 11 & 10 & 31 & <10 & <10 & <10\end{array}$ $\begin{array}{lllllllllllllll}<10 & <10 & 27 & <5 & 10 & <5 & <15 & 9 & 14 & 17 & 11 & 29 & <10 & <10 & <10\end{array}$ $\begin{array}{lllllllllllllll}<10 & <10 & <10 & <5 & 10 & <5 & <15 & 6 & 11 & <10 & <10 & 29 & <10 & <10 & <10\end{array}$ $\begin{array}{lllllllllllllll}<10 & <10 & 15 & 50 & 34 & <5 & <15 & 10 & 45 & 31 & 17 & 27 & <10 & <10 & <10\end{array}$

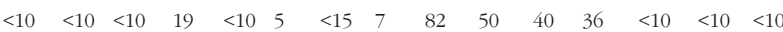
$\begin{array}{lllllllllllllll}<10 & <10 & 10 & 24 & <10 & <5 & <15 & 5 & 24 & 17 & 14 & 41 & <10 & <10 & <10\end{array}$ $\begin{array}{lllllllllllllll}<10 & <10 & 18 & 26 & <10 & <5 & <15 & <5 & 25 & 13 & <10 & 33 & <10 & <10 & <10\end{array}$ $\begin{array}{lllllllllllllll}<10 & <10 & <10 & 51 & 105 & 157 & <15 & 54 & <10 & <10 & <10 & 17 & 12 & 11 & <10\end{array}$ $\begin{array}{lllllllllllllll}<10 & <10 & <10 & 32 & <10 & 81 & <15 & 29 & <10 & <10 & <10 & 23 & <10 & <10 & <10\end{array}$ $\begin{array}{lllllllllllllll}<10 & <10 & <10 & 51 & 503 & 11 & <15 & 14 & 58 & 38 & 22 & 29 & 10 & <10 & <10\end{array}$ $\begin{array}{lllllllllllllll}<10 & <10 & 10 & 14 & <10 & 5 & <15 & <5 & 71 & 51 & 30 & 44 & <10 & <10 & <10\end{array}$ $\begin{array}{lllllllllllllll}<10 & <10 & 14 & 29 & <10 & 16 & <15 & 23 & <10 & <10 & <10 & 21 & <10 & <10 & <10\end{array}$ $\begin{array}{lllllllllllllll}<10 & <10 & <10 & 25 & <10 & 5 & <15 & 11 & 25 & <10 & 11 & 24 & <10 & <10 & <10\end{array}$ $\begin{array}{lllllllllllllll}<10 & <10 & 11 & 45 & 23 & <5 & <15 & 6 & 32 & 21 & 13 & 32 & <10 & <10 & <10\end{array}$

$\begin{array}{lllllllllllllll}<10 & <10 & <10 & 85 & 17 & 9 & <15 & 30 & 23 & <10 & 14 & 18 & <10 & <10 & <10\end{array}$ $\begin{array}{lllllllllllllll}<10 & <10 & <10 & 20 & <10 & 7 & <15 & 12 & <10 & <10 & <10 & 29 & <10 & <10 & <10\end{array}$ $\begin{array}{lllllllllllllll}<10 & <10 & <10 & 15 & <10 & 6 & <15 & 10 & 12 & <10 & 12 & 21 & <10 & <10 & <10\end{array}$ $\begin{array}{lllllllllllllll}<10 & <10 & 15 & 90 & <10 & 8 & <15 & 50 & 49 & 33 & 28 & <10 & <10 & 24 & <10\end{array}$ $\begin{array}{lllllllllllllll}<10 & <10 & <10 & 63 & 64 & 51 & <15 & 46 & <10 & 10 & 14 & 18 & <10 & 13 & <10\end{array}$ $\begin{array}{lllllllllllllll}<10 & <10 & <10 & 65 & <10 & 31 & <15 & 59 & 10 & 12 & 11 & <10 & <10 & 17 & <10\end{array}$

$\begin{array}{lllllllllllllll}<10 & <10 & <10 & 49 & 38 & 87 & <15 & 40 & <10 & <10 & <10 & 17 & <10 & <10 & <10\end{array}$ $\begin{array}{lllllllllllllll}<10 & <10 & <10 & 51 & <10 & 7 & <15 & 9 & 34 & 32 & 12 & 35 & 10 & <10 & <10\end{array}$ $\begin{array}{lllllllllllllll}<10 & <10 & 21 & 61 & 10 & <5 & <15 & 6 & 12 & <10 & <10 & 27 & <10 & <10 & <10\end{array}$ $\begin{array}{lllllllllllllll}<10 & <10 & 11 & 7 & 13 & <5 & <15 & <5 & 27 & 14 & 14 & 31 & <10 & <10 & <10\end{array}$ $\begin{array}{lllllllllllllll}<10 & <10 & 18 & 9 & 10 & <5 & <15 & 6 & 11 & <10 & <10 & 32 & <10 & <10 & <10\end{array}$ $\begin{array}{lllllllllllllll}<10 & <10 & 17 & 9 & 12 & <5 & <15 & 7 & 13 & <10 & <10 & 32 & <10 & <10 & <10\end{array}$ $\begin{array}{lllllllllllllll}<10 & <10 & 17 & 87 & 17 & <5 & <15 & 7 & 84 & 45 & 35 & 27 & <10 & <10 & <10\end{array}$ $\begin{array}{lllllllllllllll}<10 & 10 & <10 & 63 & <10 & <5 & <15 & 6 & 87 & 81 & 54 & 37 & 11 & <10 & 10\end{array}$ $\begin{array}{lllllllllllllll}<10 & <10 & 15 & 50 & 10 & <5 & <15 & 10 & 63 & 36 & 20 & 29 & <10 & <10 & <10\end{array}$ $\begin{array}{lllllllllllllll}<10 & <10 & 15 & 51 & <10 & 28 & <15 & 13 & 46 & 22 & 13 & 18 & <10 & <10 & 14\end{array}$ $\begin{array}{lllllllllllllll}<10 & <10 & <10 & <5 & <10 & <5 & <15 & <5 & 12 & <10 & <10 & <10 & <10 & 12 & <10\end{array}$ $\begin{array}{lllllllllllllll}<10 & <10 & 11 & 9 & <10 & <5 & <15 & <5 & 37 & 21 & <10 & 27 & <10 & <10 & <10\end{array}$ $\begin{array}{lllllllllllllll}<10 & <10 & <10 & 18 & <10 & <5 & <15 & 9 & <10 & <10 & <10 & 45 & <10 & <10 & <10\end{array}$ 


\begin{tabular}{|c|c|c|c|c|c|c|c|c|c|c|c|c|c|c|c|c|c|c|}
\hline Sample & UTM, $\mathbf{E}$ & UTM, $\mathbf{N}$ & Zone & Field name & Tectonic Unit & $\mathrm{SiO}_{2}$ & $\mathrm{TiO}_{2}$ & $\mathrm{Al}_{2} \mathrm{O}_{3}$ & $\mathrm{Fe}_{2} \mathrm{O}_{3}$ & FeOt & Mgo & $\mathrm{CaO}$ & $\mathrm{Na}_{2} \mathrm{O}$ & $\mathbf{K}_{2} \mathrm{O}$ & Mno & $\mathbf{P}_{2} \mathrm{O}_{5}$ & Gl.tap & SUM \\
\hline 40669 & 574059 & 8654400 & 37 & Quartz & Lalamo Complex & 99.48 & 0.00 & 0.01 & 0.00 & 0.00 & $<0.01$ & 0.03 & $<0.1$ & $<0.01$ & $<0.01$ & $<0.01$ & 0.05 & 99.47 \\
\hline 33239 & 577317 & 8548844 & 37 & Amphibolite & Lalamo Complex & 46.80 & 0.81 & 14.15 & 10.22 & 9.20 & 7.89 & 16.21 & 1.27 & 0.45 & 0.40 & 0.07 & 0.29 & 98.55 \\
\hline 33238 & 580578 & 8551342 & 37 & Quartz & Lalamo Complex & 99.51 & $<0.01$ & $<0.01$ & 0.024 & 0.02 & $<0.01$ & 0.01 & $<0.1$ & $<0.01$ & $<0.01$ & $<0.01$ & 0.04 & 99.56 \\
\hline 33330 & 585257 & 8559576 & 37 & Dyke & Lalamo Complex & 71.95 & 0.27 & 14.92 & 1.44 & 1.30 & 0.34 & 1.30 & 3.78 & 4.61 & 0.03 & 0.06 & 0.47 & 99.17 \\
\hline 33329 & 585257 & 8559576 & 37 & Mica gneiss & Lalamo Complex & 73.00 & 0.17 & 13.75 & 1.38 & 1.24 & 0.42 & 1.95 & 3.27 & 3.80 & 0.02 & 0.05 & 0.22 & 98.04 \\
\hline 40720 & 589143 & 8661328 & 37 & Ultramafic rock & Lalamo Complex & 36.15 & 0.04 & 1.82 & 13.41 & 12.07 & 33.78 & 0.04 & $<0.1$ & 0.01 & 0.10 & 0.02 & 12.30 & 97.58 \\
\hline 40721 & 591998 & 8635413 & 37 & Amphibolite & Lalamo Complex & 49.93 & 0.66 & 16.65 & 10.21 & 9.19 & 6.29 & 10.42 & 3.41 & 0.32 & 0.25 & 0.10 & 0.46 & 98.70 \\
\hline 33327 & 593749 & 8542508 & 37 & Tonalitic gneiss? & Lalamo Complex & 66.30 & 0.39 & 16.83 & 2.62 & 2.36 & 1.36 & 4.10 & 4.59 & 1.71 & 0.05 & 0.14 & 0.32 & 98.42 \\
\hline 38415 & 601327 & 8623420 & 37 & Biotite gneiss & Lalamo Complex & 64.30 & 0.72 & 15.76 & 4.97 & 4.47 & 1.43 & 3.39 & 4.35 & 3.25 & 0.09 & 0.21 & 0.51 & 98.99 \\
\hline 38414 & 603959 & 8623394 & 37 & Granite & Lalamo Complex & 67.22 & 0.87 & 14.80 & 3.24 & 2.92 & 0.79 & 1.57 & 3.47 & 5.35 & 0.03 & 0.22 & 0.42 & 97.97 \\
\hline 40758 & 606223 & 8611490 & 37 & Granitic gneiss & Lalamo Complex & 67.25 & 0.83 & 14.95 & 3.86 & 3.47 & 0.83 & 2.09 & 3.80 & 4.44 & 0.04 & 0.23 & 0.64 & 98.96 \\
\hline 33230 & 608377 & 8561868 & 37 & Graphite gneiss & Lalamo Complex & 65.34 & 0.209 & 2.18 & 0.826 & 0.74 & 0.48 & 0.03 & $<0.1$ & 0.363 & 0.011 & 0.010 & 26.73 & 96.23 \\
\hline 33231 & 608377 & 8561868 & 37 & Graphite gneiss & Lalamo Complex & 66.06 & 0.151 & 2.35 & 0.168 & 0.15 & 0.11 & 0.59 & 0.34 & 0.099 & $<0.01$ & 0.064 & 26.01 & 95.94 \\
\hline 37247 & 615084 & 8620978 & 37 & Mafic gneiss & Lalamo Complex & 52.74 & 0.45 & 9.18 & 8.65 & 7.79 & 9.81 & 15.36 & 1.64 & 0.32 & 0.44 & 0.10 & 0.37 & 99.05 \\
\hline 40730 & 630695 & 8548839 & 37 & Ultramafic rock & Lalamo Complex & 45.09 & 0.03 & 0.59 & 10.24 & 9.22 & 30.11 & 0.04 & $<0.1$ & 0.01 & 0.09 & 0.02 & 11.98 & 98.19 \\
\hline 40759 & 631213 & 8545948 & 37 & Talc schist & Lalamo Complex & 57.92 & 0.04 & 1.31 & 4.97 & 4.47 & 28.69 & 0.05 & $<0.1$ & 0.01 & 0.06 & 0.03 & 4.87 & 97.89 \\
\hline 40763 & 633555 & 8533112 & 37 & Chlorite gneiss & Lalamo Complex & 41.73 & 0.08 & 11.11 & 9.98 & 8.98 & 24.97 & 4.45 & 0.33 & 0.05 & 0.17 & 0.02 & 5.41 & 98.28 \\
\hline 40762 & 634551 & 8535488 & 37 & Amphibolitic gneiss & Lalamo Complex & 50.22 & 1.34 & 14.04 & 12.31 & 11.08 & 5.89 & 10.83 & 2.71 & 0.86 & 0.17 & 0.11 & 0.39 & 98.87 \\
\hline 40675 & 634769 & 8547124 & 37 & Granitic gneiss & Lalamo Complex & 74.13 & 0.13 & 14.66 & 1.11 & 1.00 & 0.14 & 1.28 & 4.57 & 3.85 & 0.03 & 0.04 & 0.24 & 100.18 \\
\hline 40674 & 637239 & 8549076 & 37 & Granodiorite & Lalamo Complex & 76.42 & 0.19 & 12.61 & 1.20 & 1.08 & 0.25 & 1.34 & 3.68 & 3.65 & 0.02 & 0.03 & 0.24 & 99.62 \\
\hline 40673 & 637239 & 8549076 & 37 & Quartz diorite & Lalamo Complex & 65.87 & 0.52 & 16.11 & 3.62 & 3.26 & 1.85 & 5.15 & 4.22 & 1.25 & 0.06 & 0.09 & 0.46 & 99.21 \\
\hline
\end{tabular}

$\begin{array}{llll}33212 & 496595 & 8539366 & 37\end{array}$ $332435021818552008 \quad 37$ $\begin{array}{lllll}33322 & 504094 & 8512728 & 37\end{array}$ $33323 \quad 5125428514412 \quad 37$ $\begin{array}{llll}33324 & 513150 & 8513668 & 37\end{array}$ $\begin{array}{llll}38428 & 514523 & 8551754 & 37\end{array}$ $\begin{array}{lllll}33335 & 520952 & 8555494 & 37\end{array}$ $33236524518 \quad 8501782 \quad 37$ $\begin{array}{llll}33332 & 565441 & 8552836 & 37\end{array}$ $33299594457 \quad 8528665 \quad 37$ $\begin{array}{lllll}40774 & 610336 & 8529262 & 37\end{array}$ $\begin{array}{llll}40769 & 613700 & 8520540 & 37\end{array}$ $40680 \quad 617024 \quad 8528262 \quad 37$ 9155

$\begin{array}{llll}40764 & 619423 & 8527248 & 37\end{array}$ $\begin{array}{lllll}40729 & 637611 & 8526796 \quad 37\end{array}$ $\begin{array}{lllll}40782 & 645465 & 8516668 & 37\end{array}$

$\begin{array}{lllll}33575 & 798906 \quad 8214662 \quad 36\end{array}$ $\begin{array}{lllll}33583 & 799366 & 8206097 \quad 36\end{array}$ $\begin{array}{lllll}33587 & 799366 & 8206097 & 36\end{array}$ $\begin{array}{lllll}33584 & 800010 & 8213567 & 36\end{array}$ $\begin{array}{lllll}33588 & 804705 & 8222661 & 36\end{array}$ $\begin{array}{llll}33585 & 809285 & 8226662 & 36\end{array}$ $\begin{array}{llll}26811 & 370941 & 8387034 & 37\end{array}$ $\begin{array}{lllll}26810 & 486474 & 8437474 & 37\end{array}$ $\begin{array}{llll}33340 & 545000 & 8490408 & 37\end{array}$ $\begin{array}{llll}33314 & 584918 & 8504618 & 37\end{array}$ $\begin{array}{llll}33245 & 585277 & 8506126 & 37\end{array}$ $\begin{array}{llll}33247 & 585277 & 8506126 & 37\end{array}$ $\begin{array}{llll}33248 & 585277 & 8506126 & 37\end{array}$ $\begin{array}{llll}33298 & 596463 & 8510768 \quad 37\end{array}$ $\begin{array}{lllll}33307 & 608008 & 8506110 & 37\end{array}$ $\begin{array}{llll}33304 & 608375 & 8511931 & 37\end{array}$ $\begin{array}{lllll}33399 & 608426 & 8509552 & 37\end{array}$ $\begin{array}{llll}33305 & 608605 & 8508344 & 37\end{array}$ $\begin{array}{lllll}33311 & 608733 & 8506279 & 37\end{array}$ $\begin{array}{llll}33308 & 608733 & 8506279 & 37\end{array}$ $\begin{array}{lllll}33309 & 608733 & 8506279 & 37\end{array}$ $\begin{array}{llll}40786 & 609581 & 8518780 & 37\end{array}$ $\begin{array}{lllll}40773 & 614846 & 8519218 & 37\end{array}$ $\begin{array}{lllll}40770 & 616013 & 8517514 & 37\end{array}$ $\begin{array}{lllll}40772 & 616113 & 8515656 & 37\end{array}$ $\begin{array}{llll}40771 & 616740 & 8515130 & 37\end{array}$ $\begin{array}{lllll}40693 & 619085 & 8506266 \quad 37\end{array}$ $\begin{array}{lllll}40686 & 631450 & 8507396 & 37\end{array}$ $\begin{array}{llll}26862 & 395319 & 8401459 & 37\end{array}$
Quartz, coarse grained Granodioritic gneiss

Granitic gneiss

Banded hbl-gneiss

Quartzo-feldspathic gneiss Amphibolite

Paragneiss. Metaarkose(?)

Quartz-dioritic gneiss

Granitic/tonalitic gneiss granitic gneiss

Graphite gneiss

Tonalitic gneiss

Minerais rara

Marble

Metagabbro

Graphite gneiss

Amphibolite/metagabbro

2px granulites +/- garnet

Felsic/intermediate granulites/charnockites 2px granulites +/- garnet

Felsic/intermediate granulites/charnockites 2px granulites +/- garnet

Granitic gneiss (105)

Felsic granulite - mylonitic (401)

Granodioritic orthogneiss

Grt amphibolite

Amphibolite

Amphibolite

Silisified amphibolite

Grt gneiss

Grt amphibolite

diorite gneiss

Quartz paragneiss

Grt amphibolite

Grt amphibolite

Hornblendite

Hornblendite

Iron ore

Iron ore

Magnetite-bearing quartzitic gneiss

Quartz-feldspar gneiss

Dioritic gneiss

Marble

Banded granulite, intermediate

Very felsic garnet leucogneiss (613)

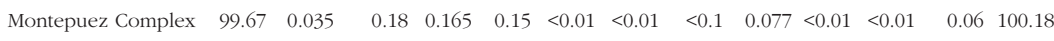

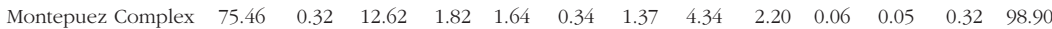
$\begin{array}{llllllllllllll}\text { Montepuez Complex } & 73.29 & 0.18 & 12.43 & 1.54 & 1.39 & 0.15 & 0.65 & 3.14 & 4.74 & 0.03 & 0.03 & 0.35 & 96.53\end{array}$

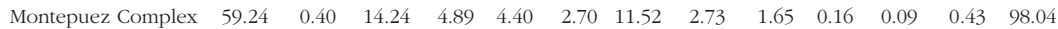
$\begin{array}{llllllllllllll}\text { Montepuez Complex } & 96.75 & 0.043 & 1.22 & 0.272 & 0.24 & 0.06 & 0.03 & <0.1 & 0.495 & <0.01 & <0.01 & 0.39 & 99.30\end{array}$ $\begin{array}{llllllllllllll}\text { Montepuez Complex } & 51.63 & 0.64 & 11.84 & 7.80 & 7.02 & 6.84 & 14.23 & 2.49 & 0.34 & 0.17 & 0.12 & 2.62 & 98.72\end{array}$ $\begin{array}{llllllllllllll}\text { Montepuez Complex } & 75.82 & 0.11 & 12.28 & 1.00 & 0.90 & 0.12 & 0.51 & 2.64 & 5.14 & 0.02 & 0.02 & 0.42 & 98.07\end{array}$ $\begin{array}{llllllllllllll}\text { Montepuez Complex } & 60.15 & 0.59 & 14.10 & 4.50 & 4.05 & 3.81 & 8.65 & 1.87 & 4.57 & 0.08 & 0.16 & 0.39 & 98.87\end{array}$ $\begin{array}{llllllllllllll}\text { Montepuez Complex } & 74.17 & 0.18 & 13.24 & 1.46 & 1.31 & 0.21 & 1.14 & 3.41 & 4.28 & 0.03 & 0.04 & 0.25 & 98.40\end{array}$ $\begin{array}{llllllllllllll}\text { Montepuez Complex } & 73.62 & 0.20 & 14.08 & 1.71 & 1.54 & 0.49 & 2.30 & 3.76 & 2.56 & 0.03 & 0.05 & 0.21 & 99.02\end{array}$ $\begin{array}{llllllllllllll}\text { Montepuez Complex } & 69.58 & 1.07 & 8.57 & 2.48 & 2.23 & 0.05 & 1.46 & 1.88 & 0.66 & <0.01 & 0.16 & 13.32 & 99.23\end{array}$ $\begin{array}{llllllllllllll}\text { Montepuez Complex } & 66.68 & 0.42 & 16.40 & 4.49 & 4.04 & 1.23 & 5.03 & 4.01 & 0.38 & 0.14 & 0.14 & 0.14 & 99.05\end{array}$ $\begin{array}{llllllllllllll}\text { Montepuez Complex } & 30.66 & 0.60 & 17.80 & 5.95 & 5.36 & 2.22 & 12.44 & <0.1 & 0.04 & <0.01 & 0.01 & 2.25 & 71.50\end{array}$

$\begin{array}{llllllllllll}\text { Montepuez Complex } & 1.77 & 0.03 & 0.14 & 0.21 & 0.19 & 0.81 & 53.91 & <0.1 & 0.040 & 0.005 & 0.01\end{array}$ $\begin{array}{llllllllllllll}\text { Montepuez Complex } & 48.54 & 0.83 & 17.64 & 6.96 & 6.26 & 7.94 & 13.03 & 2.19 & 0.15 & 0.14 & 0.32 & 1.28 & 99.01\end{array}$

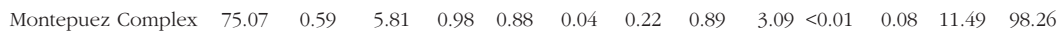

Ocua Complex

Ocua Complex

Ocua Complex

Ocua Complex

Ocua Complex

Ocua Complex

Ocua Complex

Ocua Complex

Ocua Complex

Ocua Complex

Ocua Complex

Ocua Complex

Ocua Complex

Ocua Complex

Ocua Complex

Ocua Complex

Ocua Complex

Ocua Complex

Ocua Complex

Ocua Complex

Ocua Complex

Ocua Complex

Ocua Complex

Ocua Complex

Ocua Complex

Ocua Complex

Ocua Complex

Ocua Complex

Ocua Complex $\begin{array}{lllllllllllll}52.46 & 2.27 & 16.81 & 8.14 & 7.33 & 3.41 & 6.27 & 4.44 & 3.46 & 0.11 & 0.87 & 0.13 & 98.38\end{array}$ $\begin{array}{lllllllllllll}50.72 & 1.89 & 14.05 & 15.08 & 13.57 & 1.73 & 6.69 & 2.62 & 5.09 & 0.22 & 0.58 & 0.02 & 98.69\end{array}$ $\begin{array}{lllllllllllll}59.45 & 0.64 & 13.22 & 7.90 & 7.11 & 1.46 & 6.06 & 3.12 & 6.44 & 0.15 & 0.20 & 0.54 & 99.19\end{array}$ $\begin{array}{lllllllllllll}62.92 & 0.64 & 15.11 & 6.40 & 5.76 & 1.86 & 5.75 & 3.66 & 1.05 & 0.13 & 0.16 & 0.51 & 98.18\end{array}$ $\begin{array}{lllllllllllll}60.49 & 1.87 & 15.43 & 3.09 & 2.78 & 1.05 & 5.55 & 4.96 & 5.26 & 0.08 & 0.29 & 0.75 & 98.82\end{array}$ $\begin{array}{lllllllllllll}45.45 & 0.79 & 15.00 & 17.56 & 15.80 & 8.39 & 9.37 & 1.47 & 0.34 & 0.25 & 0.05 & -0.36 & 98.32\end{array}$ $\begin{array}{lllllllllllll}65.40 & 0.68 & 14.76 & 5.89 & 5.30 & 0.55 & 2.11 & 3.91 & 4.47 & 0.12 & 0.17 & 0.08 & 98.14\end{array}$ $\begin{array}{lllllllllllll}71.60 & 0.44 & 13.30 & 2.94 & 2.65 & 0.35 & 1.99 & 3.24 & 4.09 & 0.05 & 0.10 & 0.19 & 98.30\end{array}$ $\begin{array}{lllllllllllll}66.86 & 0.24 & 16.36 & 3.21 & 2.89 & 0.83 & 5.71 & 3.90 & 0.53 & 0.08 & 0.10 & 0.18 & 98.01\end{array}$ $\begin{array}{lllllllllllll}56.87 & 1.12 & 16.41 & 7.28 & 6.55 & 3.69 & 6.03 & 3.74 & 2.72 & 0.11 & 0.28 & 0.18 & 98.43\end{array}$ $\begin{array}{lllllllllllll}49.19 & 2.04 & 14.78 & 13.57 & 12.21 & 6.32 & 9.75 & 2.68 & 0.32 & 0.23 & 0.33 & -0.10 & 99.11\end{array}$ $\begin{array}{lllllllllllll}54.48 & 1.43 & 14.65 & 10.05 & 9.05 & 4.79 & 8.65 & 3.24 & 0.70 & 0.18 & 0.20 & 0.41 & 98.80\end{array}$ $\begin{array}{lllllllllllll}61.56 & 0.98 & 13.24 & 9.65 & 8.69 & 4.04 & 4.75 & 3.47 & 0.50 & 0.23 & 0.12 & 0.13 & 98.67\end{array}$ $\begin{array}{lllllllllllll}71.31 & 0.36 & 13.30 & 5.08 & 4.57 & 0.91 & 4.18 & 3.44 & 0.36 & 0.10 & 0.07 & 0.07 & 99.17\end{array}$ $\begin{array}{lllllllllllll}55.73 & 1.32 & 16.64 & 8.21 & 7.39 & 3.51 & 6.70 & 3.67 & 1.72 & 0.11 & 0.45 & 0.51 & 98.56\end{array}$ $\begin{array}{lllllllllllll}57.74 & 0.67 & 14.24 & 4.28 & 3.85 & 2.86 & 5.28 & 2.35 & 8.46 & 0.07 & 0.80 & 0.16 & 96.91\end{array}$ $\begin{array}{lllllllllllll}65.15 & 0.60 & 16.46 & 4.82 & 4.34 & 1.60 & 4.64 & 3.84 & 1.33 & 0.07 & 0.16 & 0.12 & 98.78\end{array}$ $\begin{array}{lllllllllllll}58.96 & 1.40 & 17.02 & 10.05 & 9.05 & 3.75 & 3.12 & 2.72 & 1.95 & 0.13 & 0.24 & -0.27 & 99.08\end{array}$ $\begin{array}{lllllllllllll}46.57 & 1.06 & 15.09 & 11.58 & 10.42 & 8.58 & 12.47 & 2.30 & 0.38 & 0.20 & 0.12 & 0.59 & 98.96\end{array}$ $\begin{array}{lllllllllllll}39.78 & 0.32 & 6.62 & 12.36 & 11.12 & 27.90 & 5.15 & 0.74 & 0.22 & 0.18 & 0.12 & 5.33 & 98.72\end{array}$ $\begin{array}{lllllllllllll}39.80 & 0.34 & 6.94 & 12.79 & 11.51 & 27.64 & 4.63 & 0.91 & 0.25 & 0.21 & 0.10 & 4.90 & 98.52\end{array}$ $\begin{array}{lllllllllllll}0.00 & 1.72 & 3.11 & 93.65 & 84.29 & 0.84 & 0.02 & <0.1 & <0.01 & 0.15 & 0.01 & -3.02 & 94.12\end{array}$

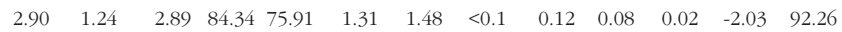
$\begin{array}{lllllllllllll}48.37 & 1.34 & 15.43 & 13.11 & 11.80 & 4.97 & 10.03 & 3.75 & 0.94 & 0.22 & 0.23 & 0.26 & 98.65\end{array}$ $\begin{array}{lllllllllllll}73.86 & 0.25 & 12.37 & 4.53 & 4.08 & 0.27 & 2.91 & 3.55 & 0.43 & 0.11 & 0.05 & 0.30 & 98.63\end{array}$ $\begin{array}{lllllllllllll}60.16 & 0.87 & 15.59 & 7.36 & 6.62 & 3.10 & 6.12 & 3.72 & 0.96 & 0.11 & 0.15 & 0.36 & 98.50\end{array}$ $\begin{array}{lllllllllll}0.00 & 0.00 & 0.00 & 0.08 & 0.07 & 21.59 & 31.32 & <0.1 & 0.003 & 0.030 & 0.04\end{array}$

$\begin{array}{lllllllllllll}59.98 & 0.98 & 16.31 & 7.15 & 6.44 & 2.61 & 4.70 & 3.46 & 1.93 & 0.09 & 0.34 & 0.61 & 98.16\end{array}$ $\begin{array}{lllllllllllll}76.56 & 0.06 & 12.34 & 0.76 & 0.68 & <0.01 & 0.59 & 3.47 & 4.83 & 0.02 & 0.02 & 0.12 & 98.75\end{array}$ 


$\begin{array}{llllllllllllllllllllllllllllllllllll}\mathbf{S} & \mathbf{C l} & \mathbf{F} & \mathbf{M o} & \mathbf{N b} & \mathbf{Z r} & \mathbf{Y} & \mathbf{S r} & \mathbf{R b} & \mathbf{U} & \mathbf{T h} & \mathbf{P b} & \mathbf{C r} & \mathbf{V} & \mathbf{A s} & \mathbf{S c} & \mathbf{H f} & \mathbf{B a} & \mathbf{S b} & \mathbf{S n} & \mathbf{G a} & \mathbf{Z n} & \mathbf{C u} & \mathbf{N i} & \mathbf{Y b} & \mathbf{C o} & \mathbf{C e} & \mathbf{L a} & \mathbf{N d} & \mathbf{w} & \mathbf{C s} & \mathbf{T a} & \mathbf{P r} \\ <0.1 & <0.1 & 0.1 & <5 & <5 & 18 & <5 & <5 & <5 & <10 & 8 & <10 & 11 & <10 & 5 & <10 & <10 & 28 & <10 & <10 & <10 & 11 & 11 & <5 & <15 & 8 & <10 & <10 & <10 & 44 & <10 & <10 & <10\end{array}$

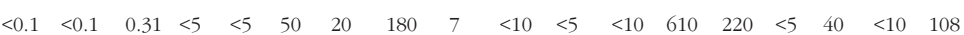
$\begin{array}{llllllllllllllllll}<0.1 & <0.1 & <0.1 & <5 & <5 & 20 & <5 & <5 & <5 & <10 & 5 & <10 & <10 & <10 & <5 & <10 & <10 & <10\end{array}$ $\begin{array}{llllllllllllllllll}<0.1 & <0.1 & <0.1 & <5 & <5 & 161 & <5 & 386 & 88 & <10 & 15 & 19 & 10 & 18 & <5 & <10 & <10 & 1865\end{array}$

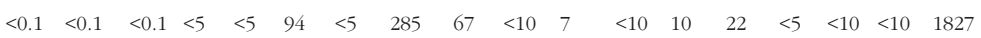

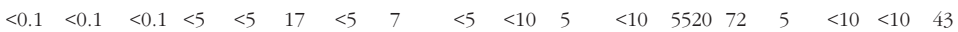
$\begin{array}{llllllllllllllllll}<0.1 & <0.1 & <0.1 & <5 & <5 & 46 & 16 & 265 & 5 & <10 & 7 & <10 & 188 & 234 & <5 & 37 & <10 & 74\end{array}$ $\begin{array}{llllllllllllllllll}<0.1 & <0.1 & <0.1 & <5 & 5 & 103 & 8 & 566 & 41 & <10 & <5 & <10 & 30 & 42 & <5 & <10 & <10 & 707\end{array}$ $\begin{array}{llllllllllllllllll}<0.1 & <0.1 & 0.1 & <5 & 9 & 309 & 44 & 200 & 94 & <10 & 7 & <10 & 15 & 48 & <5 & 20 & <10 & 783\end{array}$ $\begin{array}{llllllllllllllllll}<0.1 & <0.1 & 0.23 & <5 & 7 & 541 & 14 & 800 & 97 & <10 & 15 & 23 & 13 & 39 & <5 & <10 & 23 & 3892\end{array}$ $\begin{array}{cccccccccccccccccc}<0.1 & <0.1 & <0.1 & <5 & 15 & 612 & 48 & 316 & 90 & <10 & 16 & 15 & <10 & 43 & <5 & 10 & 70 & 1703\end{array}$ $\begin{array}{llllllllllllllllll}0.10 & <0.1 & <0.1 & 57 & <5 & 79 & 54 & 17 & 17 & <10 & 6 & <10 & 720 & 5119 & <5 & 20 & <10 & 406\end{array}$ $\begin{array}{llllllllllllllllll}<0.1 & <0.1 & <0.1 & 6 & 7 & 53 & 68 & 49 & <5 & <10 & <5 & <10 & 173 & 812 & <5 & 14 & <10 & 75\end{array}$

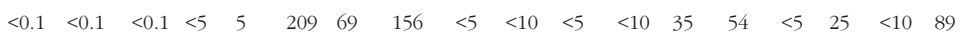
$\begin{array}{llllllllllllllllll}<0.1 & <0.1 & <0.1 & <5 & <5 & 18 & <5 & <5 & <5 & <10 & 6 & <10 & 4661 & 35 & <5 & <10 & <10 & 32\end{array}$ $\begin{array}{llllllllllllllllll}<0.1 & <0.1 & <0.1 & <5 & <5 & 18 & <5 & 6 & <5 & <10 & 6 & <10 & 2968 & 31 & 5 & <10 & <10 & 77\end{array}$

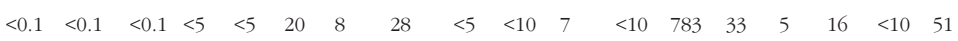

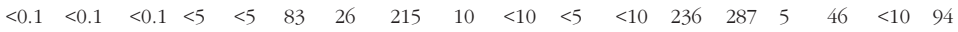
$\begin{array}{llllllllllllllllll}<0.1 & <0.1 & <0.1 & <5 & 8 & 114 & 7 & 209 & 94 & <10 & 10 & 27 & 12 & <10 & <5 & <10 & <10 & 894\end{array}$

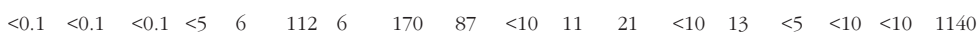

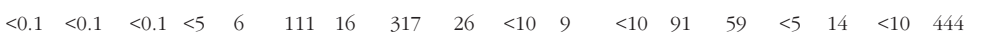

$\begin{array}{llllllllllllllllll}<0.1 & <0.1 & <0.1 & <5 & <5 & 68 & <5 & <5 & <5 & <10 & 6 & <10 & 13 & <10 & <5 & <10 & <10 & 33\end{array}$

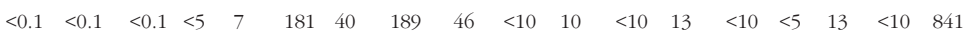
$\begin{array}{llllllllllllllllll}<0.1 & <0.1 & <0.1 & <5 & 14 & 160 & 26 & 70 & 169 & <10 & 19 & 32 & 105 & <10 & <5 & <10 & <10 & 578\end{array}$

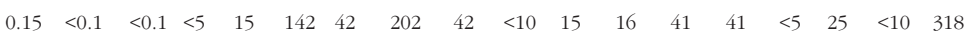
$\begin{array}{llllllllllllllllll}<0.1 & <0.1 & <0.1 & <5 & <5 & 40 & <5 & 22 & 20 & <10 & <5 & <10 & 13 & <10 & <5 & <10 & <10 & 135\end{array}$

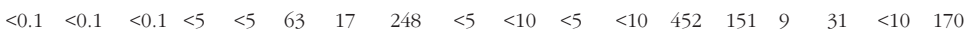
$\begin{array}{llllllllllllllllll}<0.1 & <0.1 & <0.1 & <5 & 38 & 129 & 11 & 30 & 291 & <10 & 26 & 31 & 11 & <10 & <5 & <10 & <10 & 188\end{array}$ $\begin{array}{llllllllllllllllll}<0.1 & <0.1 & 0.15 & <5 & 12 & 200 & 39 & 164 & 159 & <10 & 16 & 11 & 58 & 56 & <5 & 19 & 10 & 572\end{array}$

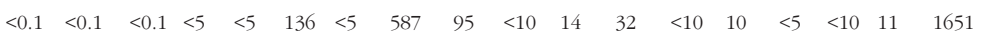
$\begin{array}{llllllllllllllllll}<0.1 & <0.1 & <0.1 & <5 & 6 & 106 & 7 & 304 & 46 & <10 & 9 & <10 & 21 & 19 & <5 & <10 & <10 & 1172\end{array}$ $\begin{array}{llllllllllllllllll}0.96 & <0.1 & <0.1 & 11 & 10 & 178 & 36 & 184 & 7 & <10 & 10 & 14 & 145 & 404 & <5 & 19 & <10 & 2932\end{array}$ $\begin{array}{llllllllllllllllll}<0.1 & <0.1 & <0.1 & <5 & 6 & 90 & 12 & 682 & 5 & <10 & <5 & <10 & 19 & 32 & <5 & 16 & <10 & 255\end{array}$ $\begin{array}{lllllllllllllllllll}<0.1 & <0.1 & 0.37 & 50 & 71 & 116 & <5 & 1745 & <5 & <10 & 17394494 & 821 & 44 & <5 & <10 & <10 & 212\end{array}$

$\begin{array}{llllllllllllllllll}<0.1 & <0.1 & <0.1 & 8 & <5 & 22 & <5 & 872 & <5 & <10 & <5 & 12 & <10 & <10 & <5 & 36 & <10 & 98\end{array}$ $\begin{array}{llllllllllllllllll}<.1 & <0.1 & <0.1 & <5 & <5 & 29 & 18 & 464 & <5 & <10 & <5 & <10 & 321 & 115 & <5 & 46 & <10 & 123\end{array}$ $\begin{array}{llllllllllllllllll}0.50 & <0.1 & <0.1 & 51 & 13 & 169 & 27 & 174 & 54 & 17 & 18 & 17 & 90 & 176 & 8 & 13 & <10 & 1635\end{array}$

$\begin{array}{llllllllllllllllll}<0.1 & <0.1 & 0.21 & <5 & 26 & 425 & 28 & 1437 & 82 & <10 & <5 & 23 & 45 & 138 & <5 & 16 & 43 & 1665\end{array}$ $<0.1<0.1 \quad<0.1<5 \quad 30 \quad 200 \quad 56$ $<0.1<0.1 \quad<0.1<5 \quad 21 \quad 893 \quad 21$ $<0.1<0.1 \quad<0.1<5 \quad 6 \quad 27 \quad 18$ $\begin{array}{lllllll}<0.1 & <0.1 & <0.1 & <5 & 72 & 102 & 49 \\ <0.1 & <0.1 & <0.1 & <5 & 5 & 30 & 18\end{array}$ $\begin{array}{lllllll}<0.1 & <0.1 & <0.1 & <5 & 5 & 30 & 18 \\ <0.1 & <0.1 & <0.1 & <5 & 85 & 565 & 87\end{array}$ $\begin{array}{lllllll}<0.1 & <0.1 & <0.1 & <5 & 85 & 565 & 87 \\ <0.1 & <0.1 & <0.1 & <5 & 7 & 247 & 26\end{array}$ $<0.1<0.1 \quad<0.1<5 \quad<5 \quad 40 \quad 6$ $<0.1<0.1 \quad 0.18<5 \quad 7 \quad 214 \quad 25$ $\begin{array}{lllllll}0.15 & <0.1 & 0.31 & <5 & 16 & 107 & 46\end{array}$ $\begin{array}{lllllll}0.36 & <0.1 & 0.31 & <5 & 7 & 84 & 37\end{array}$ $0.19<0.1 \quad 0.13<5 \quad 8 \quad 152 \quad 43$ $<0.1<0.1<0.1<5 \quad<5 \quad 100 \quad 34$ $<0.1<0.1 \quad 0.22<5 \quad 15 \quad 237 \quad 45$ $<0.1<0.1 \quad 0.33<5 \quad<5 \quad 98 \quad 25$ $<0.1<0.1 \quad<0.1<5 \quad 8 \quad 128 \quad 19$ $<0.1<0.1 \quad<0.1<5 \quad 13 \quad 198 \quad 41$ $<0.1<0.1 \quad 0.26<5 \quad<5 \quad 61 \quad 25$ $<0.1<0.1<0.1<5 \quad<5 \quad 40 \quad 9$ $<0.1<0.1 \quad<0.1<5 \quad<5 \quad 41 \quad 11$ $\begin{array}{cccccccc}<0.1 & <0.1 & 0.27 & 9 & 8 & 16 & <5\end{array}$ $\begin{array}{lllllll}<0.1 & 0.14 & 0.15 & 7 & 9 & 34 & 8 \\ <0.1 & <0.1 & <0.1 & <5 & 5 & 84 & 29\end{array}$

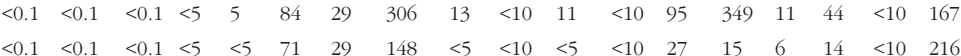
$\begin{array}{llllllllllllllllll}<0.1 & <0.1 & <0.1 & <5 & 7 & 148 & 26 & 340 & <5 & <10 & <5 & <10 & 47 & 134 & <5 & 21 & <10 & 454\end{array}$ $\begin{array}{llllllllllllllllll}<0.1 & <0.1 & <0.1 & <5 & <5 & 15 & <5 & 116 & <5 & <10 & 10 & <10 & <10 & <10 & 8 & 38 & <10 & 38\end{array}$ $\begin{array}{llllllllllllllllll}<0.1 & <0.1 & <0.1 & <5 & 10 & 258 & 28 & 430 & 63 & <10 & 13 & 13 & 42 & 84 & <5 & 19 & 13 & 715\end{array}$ $\begin{array}{llllllllllllllllll}<0.1 & <0.1 & <0.1 & <5 & <5 & 57 & 7 & 49 & 82 & <10 & 10 & 16 & 27 & <10 & <5 & 10 & <10 & 258\end{array}$ $\begin{array}{lllllllllll}82 & 49 & <10 & <5 & 12 & 80 & 133 & <5 & 19 & 19 & 905\end{array}$

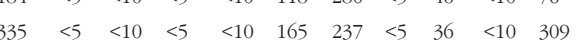

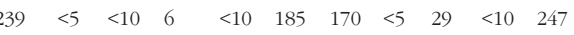
$\begin{array}{llllllllll}<5 & <10 & <5 & <10 & 42 & 51 & <5 & 21 & <10 & 145\end{array}$ $\begin{array}{lllllllllll}3237 & 202 & <10 & <5 & 11 & 49 & 54 & <5 & 10 & 37 & 7499\end{array}$ $\begin{array}{lllllllllll}373 & 28 & <10 & <5 & <10 & 37 & 44 & <5 & 11 & <10 & 421\end{array}$ $\begin{array}{llllllllllll}37 & 83 & <10 & 5 & <10 & 125 & 157 & <5 & 19 & <10 & 352\end{array}$

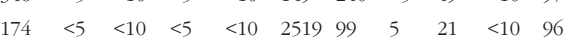
$<10 \quad 378 \quad 1338<5 \quad<10<10<10$ $\begin{array}{lllllllllllllll}<10 & <10 & 13 & 72 & 10 & 226 & <15 & 47 & <10 & <10 & <10 & <10 & <10 & <10 & <10\end{array}$ $\begin{array}{lllllllllllllll}<10 & <10 & <10 & 11 & <10 & <5 & <15 & <5 & <10 & <10 & <10 & 44 & <10 & <10 & <10\end{array}$ $\begin{array}{lllllllllllllll}<10 & <10 & 13 & 41 & <10 & <5 & <15 & <5 & 51 & 39 & 15 & 35 & <10 & <10 & <10\end{array}$ $\begin{array}{lllllllllllllll}<10 & <10 & <10 & 26 & <10 & <5 & <15 & <5 & 33 & 18 & 10 & 34 & <10 & <10 & <10\end{array}$ $\begin{array}{llllllllllllll}<10 & <10 & <10 & 49 & 124 & 6109<15 & 173 & <10 & <10 & <10 & <10 & <10 & <10 & <10\end{array}$ $\begin{array}{lllllllllllllll}<10 & <10 & 11 & 101 & <10 & 10 & <15 & 43 & 17 & 12 & <10 & 13 & <10 & <10 & 12\end{array}$ $\begin{array}{lllllllllllllll}<10 & <10 & <10 & 40 & 14 & 7 & <15 & 8 & 28 & 24 & 11 & 32 & <10 & <10 & <10\end{array}$ $\begin{array}{lllllllllllllll}<10 & <10 & 11 & 61 & <10 & 5 & <15 & 12 & 50 & 33 & 25 & 31 & <10 & <10 & <10\end{array}$ $\begin{array}{lllllllllllllll}<10 & <10 & 15 & 80 & <10 & <5 & <15 & <5 & 237 & 161 & 78 & 23 & 18 & <10 & 24\end{array}$ $\begin{array}{lllllllllllllll}<10 & <10 & <10 & 90 & 19 & <5 & <15 & 6 & 169 & 92 & 64 & 23 & 10 & <10 & 15\end{array}$ $\begin{array}{lllllllllllllll}<10 & <10 & <10 & 348 & 21 & 68 & <15 & 7 & <10 & 12 & <10 & 53 & <10 & <10 & <10\end{array}$ $\begin{array}{lllllllllllllll}<10 & <10 & <10 & 536 & 34 & 104 & <15 & 8 & 39 & 54 & 30 & 53 & <10 & <10 & <10\end{array}$ $\begin{array}{lllllllllllllll}<10 & <10 & <10 & 146 & <10 & 14 & <15 & 23 & 45 & 22 & 41 & 20 & <10 & <10 & <10\end{array}$ $\begin{array}{llllllllllllll}<10 & <10 & <10 & 46 & 14 & 3262<15 & 113 & <10 & <10 & <10 & 12 & <10 & <10 & <10\end{array}$ $\begin{array}{llllllllllllll}<10 & <10 & <10 & 52 & 18 & 1739<15 & 61 & <10 & <10 & <10 & 20 & <10 & <10 & <10\end{array}$ $\begin{array}{llllllllllllll}<10 & <10 & <10 & 83 & 18 & 1019<15 & 90 & <10 & <10 & <10 & 16 & <10 & <10 & <10\end{array}$ $\begin{array}{lllllllllllllll}<10 & <10 & 13 & 85 & <10 & 44 & <15 & 50 & 33 & <10 & <10 & <10 & <10 & 17 & <10\end{array}$ $\begin{array}{lllllllllllllll}<10 & <10 & 14 & 46 & <10 & <5 & <15 & 8 & 33 & 12 & <10 & 31 & <10 & <10 & <10\end{array}$ $\begin{array}{lllllllllllllll}<10 & <10 & <10 & 26 & 11 & <5 & <15 & 8 & 38 & 28 & 12 & 36 & <10 & <10 & <10\end{array}$ $\begin{array}{lllllllllllllll}<10 & <10 & 11 & 48 & 16 & <5 & <15 & 11 & 23 & 13 & <10 & 32 & <10 & <10 & <10\end{array}$

$\begin{array}{lllllllllllllll}<10 & <10 & <10 & 12 & <10 & <5 & <15 & <5 & <10 & <10 & <10 & 42 & <10 & <10 & <10\end{array}$ $\begin{array}{lllllllllllllll}<10 & <10 & 10 & 28 & <10 & <5 & <15 & 5 & 64 & 40 & 28 & 41 & <10 & <10 & <10\end{array}$ $\begin{array}{lllllllllllllll}<10 & <10 & 10 & 37 & 12 & <5 & <15 & <5 & 46 & 36 & 21 & 35 & <10 & <10 & <10\end{array}$ $\begin{array}{lllllllllllllll}<10 & <10 & 15 & 72 & 38 & 10 & <15 & 11 & 56 & 50 & 37 & 27 & <10 & <10 & 12\end{array}$ $\begin{array}{lllllllllllllll}<10 & <10 & <10 & 14 & <10 & <5 & <15 & <5 & <10 & 17 & <10 & 44 & <10 & <10 & <10\end{array}$ $\begin{array}{lllllllllllllll}<10 & <10 & <10 & 61 & <10 & 181 & <15 & 28 & <10 & 12 & <10 & 20 & <10 & <10 & <10\end{array}$ $\begin{array}{lllllllllllllll}<10 & 11 & 14 & 34 & <10 & <5 & <15 & <5 & 36 & 26 & 11 & 35 & <10 & <10 & <10\end{array}$ $\begin{array}{lllllllllllllll}<10 & <10 & 12 & 83 & <10 & 21 & <15 & 12 & 62 & 40 & 33 & 26 & <10 & <10 & 14\end{array}$ $\begin{array}{lllllllllllllll}<10 & <10 & 12 & 42 & <10 & <5 & <15 & <5 & 47 & <10 & <10 & 34 & <10 & <10 & <10\end{array}$ $\begin{array}{lllllllllllllll}<10 & <10 & <10 & 41 & <10 & <5 & <15 & 5 & 11 & 21 & <10 & 37 & <10 & <10 & <10\end{array}$ $\begin{array}{lllllllllllllll}<10 & <10 & 11 & 18 & 54 & <5 & <15 & 10 & 24 & 20 & 11 & 43 & <10 & <10 & <10\end{array}$ $\begin{array}{lllllllllllllll}<10 & <10 & <10 & 62 & 12 & <5 & <15 & 11 & 15 & <10 & <10 & 21 & <10 & <10 & <10\end{array}$ $\begin{array}{llllllllllll}<10 & 118 & 35 & 130 & 22 & 23 & 44 & <5 & 983702518227376 & <10 & 52 & 50\end{array}$

$\begin{array}{lllllllllllllll}<10 & <10 & <10 & 16 & <10 & <5 & <15 & <5 & <10 & <10 & <10 & <10 & <10 & <10 & <10\end{array}$ $\begin{array}{lllllllllllllll}<10 & <10 & 15 & 53 & 94 & 123 & <15 & 29 & <10 & <10 & <10 & 19 & <10 & <10 & <10\end{array}$ $\begin{array}{lllllllllllllll}<10 & <10 & <10 & 20 & 99 & 27 & <15 & 10 & 25 & 34 & 18 & 40 & <10 & <10 & <10\end{array}$

$\begin{array}{llllllllllllllllllllllllll}393 & 94 & <10 & <5 & <10 & 24 & <10 & <5 & 19 & <10 & 2079 & 10 & <10 & 21 & 237 & 11 & 18 & <15 & 26 & 134 & 46 & 82 & <10 & <10 & 23 & 12\end{array}$

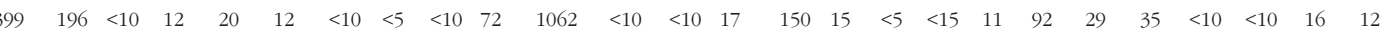
$\begin{array}{llllllllllllllllllllllllll}42 & <5 & <10 & 5 & 13 & 19 & 83 & <5 & 22 & <10 & 503 & <10 & <10 & <10 & 57 & 29 & <5 & <15 & 16 & 42 & 26 & <10 & 15 & <10 & 11 & 11\end{array}$

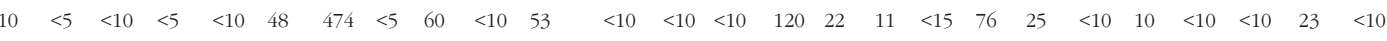

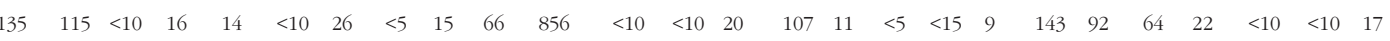
$\begin{array}{lllllllllllllllllllllllllll}374 & 94 & <10 & 6 & 12 & <10 & 27 & <5 & 11 & <10 & 2237 & <10 & <10 & 14 & 50 & 22 & <5 & <15 & 9 & 69 & 35 & 25 & 30 & <10 & <10 & <10\end{array}$ $\begin{array}{llllllllllllllllllllllllll}44 & <5 & <10 & <5 & <10 & <10 & 27 & <5 & 14 & <10 & 218 & <10 & <10 & <10 & 43 & <10 & <5 & <15 & 5 & 12 & <10 & 10 & 33 & <10 & <10 & <10\end{array}$

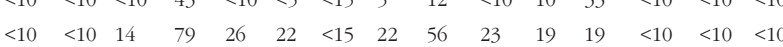
$\begin{array}{lllllllllllllll}<10 & <10 & 10 & 93 & 38 & 36 & <15 & 50 & 24 & <10 & 28 & 18 & <10 & 21 & 16\end{array}$ $\begin{array}{lllllllllllllll}<10 & <10 & 13 & 112 & 85 & 51 & <15 & 36 & 33 & <10 & 20 & 21 & <10 & <10 & <10\end{array}$ $\begin{array}{lllllllllllllll}<10 & <10 & 10 & 81 & 66 & 34 & <15 & 29 & 22 & 15 & 19 & 25 & <10 & <10 & <10\end{array}$ $\begin{array}{lllllllllllllll}<10 & <10 & 11 & 44 & <10 & <5 & <15 & 10 & <10 & 13 & 12 & 35 & <10 & <10 & <10\end{array}$ $\begin{array}{lllllllllllllll}<10 & <10 & 15 & 88 & 54 & 26 & <15 & 21 & 95 & 39 & 50 & 26 & <10 & <10 & <10\end{array}$ $\begin{array}{lllllllllllllll}<10 & <10 & 11 & 56 & 18 & 34 & <15 & 5 & 134 & 52 & 47 & 14 & 23 & <10 & <10\end{array}$ $\begin{array}{lllllllllllllll}<10 & <10 & 19 & 70 & <10 & <5 & <15 & 10 & 32 & 19 & 12 & 29 & <10 & <10 & <10\end{array}$ $\begin{array}{lllllllllllllll}<10 & <10 & 17 & 122 & 29 & 63 & <15 & 32 & 51 & 21 & 20 & 33 & <10 & <10 & <10\end{array}$ $\begin{array}{lllllllllllllll}<10 & <10 & 12 & 85 & 75 & 43 & <15 & 48 & 10 & <10 & 11 & 13 & <10 & 11 & 11\end{array}$ $\begin{array}{lllllllllllllll}<10 & <10 & <10 & 76 & 10 & 806 & 33 & 107 & <10 & 11 & <10 & 19 & <10 & <10 & <10\end{array}$ $\begin{array}{lllllllllllllll}<10 & <10 & <10 & 88 & 21 & 756 & 24 & 109 & 13 & 10 & <10 & 12 & <10 & <10 & <10\end{array}$

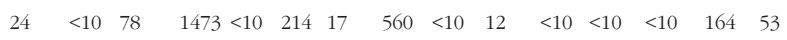

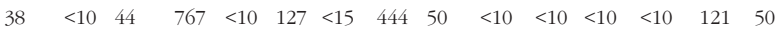
$\begin{array}{lllllllllllllll}<10 & <10 & 11 & 113 & 22 & 26 & <15 & 43 & 49 & <10 & 14 & 11 & <10 & 13 & <10\end{array}$ $\begin{array}{lllllllllllllll}<10 & <10 & 10 & 70 & 11 & <5 & <15 & 9 & 15 & 11 & <10 & 38 & <10 & <10 & <10\end{array}$ $\begin{array}{lllllllllllllll}<10 & <10 & 18 & 75 & 50 & 19 & <15 & 26 & 29 & 13 & <10 & 26 & <10 & <10 & <10\end{array}$ $\begin{array}{lllllllllllllll}<10 & <10 & <10 & 23 & <10 & <5 & <15 & <5 & <10 & <10 & <10 & 34 & <10 & <10 & <10\end{array}$ $\begin{array}{lllllllllllllll}<10 & <10 & 16 & 90 & 26 & 10 & <15 & 20 & 104 & 55 & 43 & 18 & <10 & <10 & 18\end{array}$ $\begin{array}{lllllllllllllll}<10 & <10 & 12 & 18 & 10 & <5 & <15 & 7 & 29 & 16 & <10 & 36 & <10 & <10 & <10\end{array}$ 


\begin{tabular}{|c|c|c|c|c|c|c|c|c|c|c|c|c|c|c|c|c|c|c|}
\hline 33359 & 552667 & 8491220 & 37 & Granitic gneiss & Ocua Complex & 75.34 & 0.26 & 12.45 & 1.02 & 0.92 & 0.17 & 0.81 & 3.22 & 4.84 & 0.02 & 0.04 & 0.30 & 98.48 \\
\hline Sample & UTM, E & UTM, $\mathbf{N}$ & Zone & Field name & Tectonic Unit & $\mathrm{SiO}_{2}$ & $\mathrm{TiO}_{2}$ & $\mathrm{Al}_{2} \mathrm{O}_{3}$ & $\mathrm{Fe}_{2} \mathrm{O}_{3}$ & FeOt & MgO & $\mathrm{CaO}$ & $\mathrm{Na}_{2} \mathrm{O}$ & $\mathbf{K}_{2} \mathrm{O}$ & Mno & $\mathbf{P}_{2} \mathrm{O}_{5}$ & Gl.tap & SUM \\
\hline 33358 & 568407 & 8490192 & 37 & Dioritic gneiss & Ocua Complex & 56.88 & 0.87 & 14.73 & 5.05 & 4.55 & 2.34 & 5.88 & 2.55 & 7.83 & 0.09 & 0.80 & 0.23 & 97.24 \\
\hline 33370 & 606452 & 8515446 & 37 & Amphibolitic gneiss & Ocua Complex & 47.59 & 1.22 & 16.24 & 11.15 & 10.04 & 8.24 & 10.99 & 2.44 & 0.49 & 0.18 & 0.13 & 0.26 & 98.93 \\
\hline 31824 & 686270 & 8619146 & 36 & Tremolite-rock & Ponta Messuli C. & 55.10 & 0.04 & 1.30 & 13.23 & 11.91 & 24.49 & 0.86 & $<0.1$ & 0.03 & 0.28 & 0.02 & 2.41 & 97.73 \\
\hline 38427 & 686905 & 8633817 & 36 & Amphibolite & Ponta Messuli C. & 49.25 & 1.30 & 11.56 & 12.72 & 11.45 & 9.09 & 14.15 & 0.71 & 0.31 & 0.22 & 0.11 & 0.72 & 100.16 \\
\hline 36068 & 717251 & 8710574 & 36 & Metadiorite, porphyric & Ponta Messuli C. & 62.77 & 0.82 & 16.38 & 5.57 & 5.01 & 2.95 & 4.26 & 2.57 & 2.12 & 0.08 & 0.08 & 0.71 & 98.31 \\
\hline 31779 & 691660 & 8657448 & 36 & quartz syenite & Txitonga Group & 64.80 & 0.86 & 14.95 & 4.66 & 4.19 & 1.34 & 2.16 & 2.29 & 5.87 & 0.05 & 0.42 & 0.97 & 98.36 \\
\hline 31902 & 719100 & 8679307 & 36 & Quartz-muscovite-feldspar schist (sandstone) & Txitonga Group & 51.43 & 0.84 & 23.71 & 8.62 & 7.76 & 2.16 & 0.04 & 0.21 & 6.26 & 0.09 & 0.08 & 4.14 & 97.58 \\
\hline 38413 & 724557 & 8679988 & 36 & Banded Iron Formation & Txitonga Group & 71.24 & $<0.01$ & 0.20 & 25.68 & 23.11 & 0.07 & 0.29 & 0.11 & 0.01 & 0.06 & 0.07 & 0.44 & 98.19 \\
\hline 31900 & 724567 & 8701402 & 36 & Quartz-muscovite schist & Txitonga Group & 53.37 & 1.21 & 22.19 & 10.50 & 9.45 & 0.87 & 0.01 & $<0.1$ & 5.97 & 0.12 & 0.04 & 5.07 & 99.40 \\
\hline 31901 & 727675 & 8702265 & 36 & Arkosic metasandstone & Txitonga Group & 70.73 & 0.80 & 12.54 & 3.97 & 3.57 & 1.10 & 1.24 & 2.84 & 3.11 & 0.09 & 0.17 & 2.01 & 98.60 \\
\hline 31815 & 730031 & 8708594 & 36 & banded iron formation & Txitonga Group & 17.79 & 2.34 & 19.04 & 49.23 & 44.31 & 0.73 & 0.20 & $<0.1$ & 3.04 & 0.10 & 0.07 & 4.52 & 97.03 \\
\hline 31899 & 731363 & 8717206 & 36 & Sillimanite-muscovite schist & Txitonga Group & 45.00 & 1.06 & 28.89 & 13.13 & 11.82 & 0.36 & 0.02 & $<0.1$ & 2.53 & 0.03 & 0.03 & 7.96 & 99.05 \\
\hline 31818 & 732056 & 8705434 & 36 & syenite & Txitonga Group & 75.87 & 0.18 & 12.39 & 1.52 & 1.37 & 0.25 & 1.21 & 1.95 & 5.07 & 0.03 & 0.03 & 1.54 & 100.03 \\
\hline 31819 & 732766 & 8705176 & 36 & amphibolite & Txitonga Group & 53.41 & 3.01 & 12.17 & 15.90 & 14.31 & 3.59 & 9.13 & 1.17 & 0.17 & 0.30 & 0.33 & 0.21 & 99.38 \\
\hline 31858 & 739344 & 8713876 & 36 & Epidote-chlorite schist & Txitonga Group & 56.51 & 1.05 & 20.17 & 10.38 & 9.34 & 2.01 & 0.09 & 0.78 & 3.63 & 0.12 & 0.06 & 3.83 & 98.65 \\
\hline 31856 & 739549 & 8714130 & 36 & Undeformed microgabbro & Txitonga Group & 47.32 & 2.90 & 13.85 & 15.19 & 13.67 & 5.77 & 9.43 & 1.86 & 0.26 & 0.24 & 0.34 & 1.22 & 98.38 \\
\hline 31855 & 739549 & 8714130 & 36 & Deformed and altered microgabbro & Txitonga Group & 47.02 & 1.57 & 16.67 & 18.10 & 16.29 & 8.28 & 1.15 & 0.90 & 0.41 & 0.17 & 0.14 & 5.05 & 99.45 \\
\hline 31857 & 739683 & 8714016 & 36 & Mylonitic, altered microgabbro & Txitonga Group & 50.45 & 1.11 & 22.22 & 13.15 & 11.84 & 3.20 & 0.17 & 0.89 & 3.81 & 0.13 & 0.06 & 4.10 & 99.28 \\
\hline 31325 & 710235 & 8517380 & 36 & alkali granite & Niassa Suite & 63.82 & 0.46 & 18.00 & 2.57 & 2.31 & 0.57 & 1.87 & 4.92 & 5.62 & 0.04 & 0.14 & 0.39 & 98.39 \\
\hline 31323 & 710492 & 8519070 & 36 & alkali syenite & Niassa Suite & 65.63 & 0.50 & 17.42 & 2.12 & 1.91 & 0.40 & 0.72 & 5.07 & 6.72 & 0.04 & 0.07 & 0.37 & 99.06 \\
\hline 31324 & 710585 & 8518325 & 36 & alkali granite & Niassa Suite & 71.11 & 0.34 & 14.42 & 2.04 & 1.84 & 0.40 & 1.24 & 3.74 & 5.15 & 0.04 & 0.10 & 0.32 & 98.90 \\
\hline 31246 & 746558 & 8502248 & 36 & Massive coarse-gr granitic syenite & Niassa Suite & 62.46 & 0.98 & 16.76 & 4.06 & 3.65 & 0.86 & 1.75 & 4.54 & 6.66 & 0.11 & 0.28 & 0.21 & 98.66 \\
\hline 31257 & 752010 & 8483378 & 36 & Microgranite dyke & Niassa Suite & 69.32 & 0.42 & 13.80 & 2.63 & 2.37 & 0.33 & 0.67 & 3.45 & 5.73 & 0.03 & 0.11 & 0.83 & 97.33 \\
\hline 31258 & 753045 & 8494484 & 36 & Biotite-quartz-syenite & Niassa Suite & 60.86 & 0.98 & 17.28 & 4.00 & 3.60 & 1.03 & 1.80 & 4.48 & 6.92 & 0.09 & 0.29 & 0.37 & 98.10 \\
\hline 31218 & 757796 & 8475807 & 36 & Quartz syenite/granite & Niassa Suite & 77.54 & 0.13 & 11.58 & 0.95 & 0.86 & 0.08 & 0.69 & 3.00 & 4.51 & 0.01 & 0.02 & 0.34 & 98.85 \\
\hline 31219 & 761314 & 8474877 & 36 & Quartz syenite/granite, & Niassa Suite & 65.22 & 0.45 & 17.66 & 1.70 & 1.53 & 0.29 & 0.79 & 4.75 & 7.72 & 0.03 & 0.05 & 0.29 & 98.96 \\
\hline 31225 & 763225 & 8462871 & 36 & Granite, fine to medium grained & Niassa Suite & 70.92 & 0.47 & 13.55 & 2.23 & 2.01 & 0.43 & 0.86 & 3.85 & 5.08 & 0.07 & 0.10 & 0.56 & 98.10 \\
\hline 31226 & 765611 & 8469264 & 36 & Syenite?, red, fine to medium grained. & Niassa Suite & 73.86 & 0.19 & 12.39 & 2.83 & 2.55 & 0.08 & 0.50 & 2.39 & 5.77 & 0.07 & 0.02 & 0.14 & 98.23 \\
\hline 31260 & 768529 & 8482664 & 36 & Granite & Niassa Suite & 61.78 & 0.66 & 17.94 & 4.12 & 3.71 & 0.83 & 2.73 & 4.78 & 5.06 & 0.09 & 0.29 & 0.34 & 98.61 \\
\hline 33504 & 769452 & 8447609 & 36 & Granite & Niassa Suite & 71.16 & 0.32 & 13.45 & 2.97 & 2.67 & 0.31 & 1.09 & 3.17 & 5.44 & 0.08 & 0.14 & 0.29 & 98.41 \\
\hline 33505 & 771238 & 8434430 & 36 & Biotite granite & Niassa Suite & 63.73 & 0.79 & 16.51 & 3.52 & 3.17 & 0.72 & 1.72 & 4.03 & 6.47 & 0.12 & 0.18 & 0.26 & 98.05 \\
\hline 33496 & 771524 & 8429229 & 36 & Syenite / monzonite & Niassa Suite & 65.82 & 0.64 & 15.93 & 3.06 & 2.75 & 0.51 & 0.51 & 4.18 & 6.97 & 0.07 & 0.14 & 0.29 & 98.11 \\
\hline 33497 & 251353 & 8355546 & 37 & Biotitic granite & Malema suite & 64.15 & 1.10 & 14.87 & 5.88 & 5.29 & 1.15 & 2.91 & 3.05 & 4.32 & 0.05 & 0.34 & 0.30 & 98.13 \\
\hline 33501 & 251609 & 8369522 & 37 & Monzonitic-dioritic rocks & Malema suite & 58.84 & 1.18 & 16.02 & 7.59 & 6.83 & 0.99 & 2.86 & 4.78 & 4.94 & 0.18 & 0.37 & 0.12 & 97.87 \\
\hline 33500 & 251609 & 8369522 & 37 & Late granite & Malema suite & 66.82 & 0.46 & 15.50 & 3.67 & 3.30 & 0.37 & 1.47 & 4.46 & 5.63 & 0.08 & 0.11 & 0.06 & 98.62 \\
\hline 33511 & 257967 & 8349173 & 37 & Biotite-granite & Malema suite & 63.00 & 0.73 & 14.97 & 6.58 & 5.92 & 0.53 & 2.36 & 3.41 & 6.17 & 0.10 & 0.15 & 0.06 & 98.08 \\
\hline 33495 & 262752 & 8450224 & 37 & Dolerite & Malema suite & 52.22 & 0.84 & 14.34 & 11.27 & 10.14 & 6.66 & 10.16 & 1.99 & 0.82 & 0.18 & 0.10 & 0.95 & 99.54 \\
\hline 33509 & 277501 & 8359213 & 37 & Charnockite & Malema suite & 58.30 & 1.05 & 18.07 & 6.17 & 5.55 & 0.71 & 3.98 & 4.14 & 5.13 & 0.12 & 0.35 & 0.04 & 98.04 \\
\hline 26841 & 312041 & 8376426 & 37 & Coarse-grained syenite (101) & Malema suite & 61.62 & 0.72 & 18.87 & 3.34 & 3.01 & 0.44 & 2.30 & 6.65 & 4.35 & 0.12 & 0.22 & 0.07 & 98.70 \\
\hline 26852 & 409312 & 8404279 & 37 & Banded gneiss (211) & Malema suite & 52.44 & 2.79 & 14.35 & 11.46 & 10.31 & 3.62 & 6.00 & 3.59 & 3.02 & 0.15 & 1.18 & 0.16 & 98.74 \\
\hline 26815 & 417903 & 8405591 & 37 & Gneissic qtz-diorite (205) & Malema suite & 54.69 & 2.10 & 15.70 & 9.06 & 8.15 & 3.06 & 6.22 & 3.60 & 2.70 & 0.11 & 0.74 & 0.26 & 98.24 \\
\hline 26805 & 445674 & 8426659 & 37 & Granitic gneiss (105) & Malema suite & 65.91 & 0.78 & 15.15 & 4.28 & 3.85 & 0.95 & 2.35 & 3.69 & 4.84 & 0.02 & 0.20 & 0.21 & 98.39 \\
\hline 26885 & 315669 & 8349314 & 37 & Charnokite (106) & Malema suite & 62.18 & 0.92 & 16.69 & 4.24 & 3.82 & 0.76 & 1.91 & 5.98 & 4.82 & 0.12 & 0.36 & 0.14 & 98.09 \\
\hline 26886 & 320871 & 8367730 & 37 & Pink Pan African granite/syenite (102) & Malema suite & 68.32 & 0.44 & 13.48 & 4.82 & 4.34 & 0.27 & 1.47 & 2.96 & 6.07 & 0.06 & 0.07 & 0.23 & 98.19 \\
\hline 26861 & 374602 & 8395926 & 37 & granite gneiss / Bt gneiss (105) & Malema suite & 62.59 & 0.60 & 16.15 & 4.49 & 4.04 & 1.94 & 5.27 & 4.48 & 1.88 & 0.05 & 0.20 & 0.91 & 98.56 \\
\hline 26859 & 387949 & 8404885 & 37 & Granite gneiss (105) & Malema suite & 64.00 & 0.84 & 14.59 & 6.57 & 5.91 & 0.65 & 2.37 & 3.37 & 5.24 & 0.10 & 0.23 & 0.10 & 98.06 \\
\hline 31997 & 733103 & 8625759 & 36 & Nef syenite & Neoprot intr. & 51.29 & 0.81 & 20.20 & 5.87 & 5.28 & 0.42 & 3.53 & 7.52 & 4.99 & 0.26 & 0.13 & 3.15 & 98.18 \\
\hline 31940 & 754484 & 8630700 & 36 & Granitic rock with weak fabric & Neoprot intr. & 76.98 & 0.03 & 12.18 & 1.12 & 1.01 & 0.03 & 0.15 & 4.70 & 3.84 & $<0.01$ & 0.03 & 0.35 & 99.41 \\
\hline 31941 & 754550 & 8632004 & 36 & Metadioritic rock & Neoprot intr. & 54.55 & 2.14 & 14.70 & 10.71 & 9.64 & 2.68 & 5.79 & 3.58 & 2.37 & 0.19 & 0.62 & 1.07 & 98.40 \\
\hline 37237 & 275920 & 8680606 & 37 & Granite & Neoprot intr. & 71.05 & 0.34 & 14.57 & 2.43 & 2.19 & 0.34 & 1.00 & 4.50 & 4.56 & 0.08 & 0.12 & 0.25 & 99.23 \\
\hline 31837 & 282755 & 8660808 & 37 & Monzonitic rock & Neoprot intr. & 58.12 & 0.09 & 19.17 & 5.63 & 5.07 & $<0.01$ & 0.74 & 8.25 & 4.34 & 0.37 & 0.14 & 1.41 & 98.24 \\
\hline 37231 & 287536 & 8664690 & 37 & Monzonite & Neoprot intr. & 60.52 & 0.15 & 18.76 & 5.30 & 4.77 & 0.01 & 0.96 & 7.32 & 5.21 & 0.24 & 0.05 & 0.50 & 99.02 \\
\hline 37230 & 349074 & 3668162 & 37 & Hornblende granodiorite & Neoprot intr. & 59.18 & 1.14 & 14.74 & 4.57 & 4.11 & 1.83 & 5.05 & 3.51 & 5.38 & 0.07 & 0.98 & 0.74 & 97.18 \\
\hline 37266 & 363075 & 8667867 & 37 & Syenite & Neoprot intr. & 55.22 & 1.12 & 14.39 & 4.88 & 4.39 & 2.47 & 6.97 & 2.34 & 6.65 & 0.09 & 1.12 & 0.42 & 95.65 \\
\hline 33222 & 422085 & 8514004 & 37 & Granite/granitic gneiss & Neoprot intr. & 69.92 & 0.36 & 14.73 & 2.16 & 1.94 & 0.44 & 1.48 & 3.66 & 5.18 & 0.04 & 0.10 & 0.22 & 98.29 \\
\hline 33226 & 443851 & 8547858 & 37 & Gabbro, medium grained & Neoprot intr. & 47.53 & 0.13 & 24.09 & 4.56 & 4.10 & 7.10 & 10.89 & 2.65 & 0.15 & 0.06 & 0.02 & 1.93 & 99.08 \\
\hline 33225 & 444145 & 8547158 & 37 & Gabbro, coarse grained & Neoprot intr. & 46.23 & 0.21 & 19.17 & 8.43 & 7.59 & 11.86 & 9.06 & 2.31 & 0.17 & 0.11 & 0.03 & 1.25 & 98.82 \\
\hline 33306 & 485350 & 8515258 & 37 & granite & Neoprot intr. & 70.50 & 0.36 & 14.07 & 2.61 & 2.35 & 0.47 & 1.86 & 3.09 & 4.99 & 0.04 & 0.11 & 0.22 & 98.34 \\
\hline 33214 & 485482 & 8514772 & 37 & Tonalite, porphyric & Neoprot intr. & 68.59 & 0.55 & 13.95 & 4.15 & 3.74 & 0.77 & 2.15 & 2.96 & 4.68 & 0.07 & 0.17 & 0.27 & 98.31 \\
\hline 33266 & 415746 & 8508958 & 37 & phenocryst granite & Neoprot intr. & 70.96 & 0.38 & 13.82 & 2.25 & 2.03 & 0.42 & 1.27 & 3.17 & 5.50 & 0.03 & 0.08 & 0.34 & 98.22 \\
\hline 33277 & 443612 & 8544766 & 37 & metagabbro & Neoprot intr. & 54.02 & 1.18 & 13.24 & 13.34 & 12.01 & 6.01 & 7.73 & 2.54 & 0.06 & 0.25 & 0.11 & 0.40 & 98.89 \\
\hline 33352 & 480147 & 8517972 & 37 & Diorite & Neoprot intr. & 69.02 & 0.49 & 14.78 & 3.34 & 3.01 & 0.65 & 2.33 & 3.63 & 3.93 & 0.06 & 0.14 & 0.37 & 98.73 \\
\hline 33351 & 480147 & 8517972 & 37 & Tonalite & Neoprot intr. & 71.26 & 0.25 & 13.70 & 2.00 & 1.80 & 0.34 & 1.63 & 3.58 & 4.08 & 0.05 & 0.08 & 0.22 & 97.18 \\
\hline
\end{tabular}


R. BOyd, $\varnothing$. NORDGUlen, R.J. ThOMAS, B. BINGEN, T. BJERKGÅRD, T. GRENNE, I. HENDERSON, V.A. MELEZHIK,

, OFTEN, JS, SANDSTAD, A. SOLLI, E. TVETEN, G. VIOLA, R.M. KEY, R.A. SMITH, E. GONZALEZ, L,J HOLLICK,

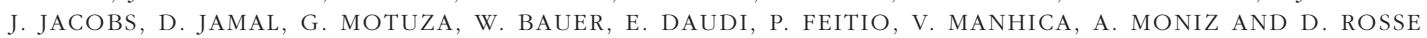

\begin{tabular}{lllllllllllllllllllllllllllllllllll}
$<0.1$ & $<0.1$ & $<0.1$ & $<5$ & $<5$ & 129 & 7 & 94 & 73 & $<10$ & 11 & $<10$ & 12 & $<10$ & $<5$ & $<10$ & $<10$ & 887 & $<10$ & $<10$ & $<10$ & 23 & $<10$ & $<5$ & $<15$ & $<5$ & 47 & 35 & 21 & 38 & $<10$ & $<10$ & $<10$ \\
\hline
\end{tabular}

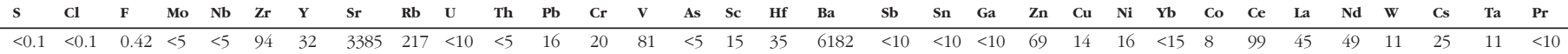
$\begin{array}{lllllllllllllllllllllllllllllllllllllllll}<0.1 & <0.1 & 0.28 & <5 & 5 & 75 & 27 & 307 & <5 & <10 & <5 & <10 & 147 & 242 & <5 & 41 & 11 & 150 & <10 & <10 & 11 & 85 & 38 & 76 & <15 & 53 & <10 & 11 & <10 & 17 & 10 & 10 & <10\end{array}$

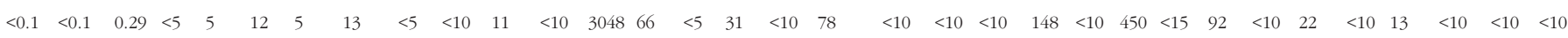
$\begin{array}{llllllllllllllllllllllllllllllllllllllllll}<0.1 & <0.1 & <0.1 & <5 & 5 & 82 & 17 & 132 & 6 & <10 & <5 & <10 & 843 & 187 & <5 & 35 & <10 & 156 & <10 & <10 & <10 & 102 & <10 & 305 & 16 & 66 & <10 & <10 & <10 & <10 & <10 & <10 & <10\end{array}$ $\begin{array}{lllllllllllllllllllllllllllllllllllllll}<0.1 & <0.1 & 0.11 & <5 & 11 & 199 & 15 & 422 & 118 & <10 & 37 & 20 & 84 & 90 & <5 & 25 & <10 & 735 & <10 & <10 & 10 & 70 & 31 & 51 & <15 & 18 & 126 & 72 & 53 & 31 & <10 & <10 & 18\end{array}$

$\begin{array}{llllllllllllllllllllllllllllllllllll}<0.1 & <0.1 & 0.13 & <5 & 21 & 485 & 20 & 300 & 193 & <10 & 82 & 50 & 23 & 68 & <5 & 10 & 14 & 1804 & <10 & <10 & 17 & 67 & 72 & 11 & <15 & 10 & 229 & 104 & 95 & 15 & 14 & <10 & 22\end{array}$ $\begin{array}{llllllllllllllllllllllllllllllllllllllllll}<0.1 & <0.1 & 0.38 & <5 & 12 & 156 & 31 & 70 & 455 & <10 & 23 & 20 & 208 & 151 & <5 & 21 & <10 & 735 & <10 & <10 & 27 & 158 & 27 & 86 & <15 & 28 & 77 & 49 & 37 & 34 & <10 & <10 & 11\end{array}$

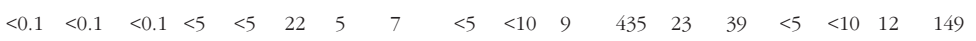

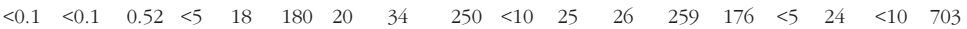

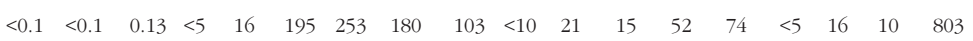
$\begin{array}{llllllllllllllllll}<0.1 & <0.1 & 0.41 & <5 & 12 & 275 & 5 & 158 & 113 & <10 & 17 & <10 & 1261 & 1030 & <5 & 47 & 31 & 373\end{array}$

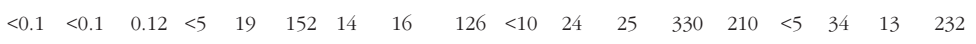

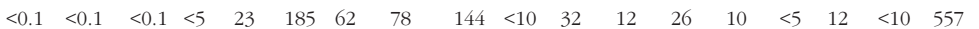

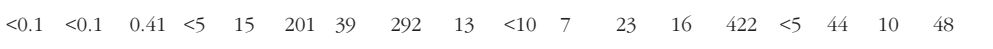

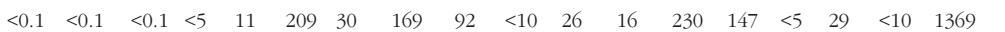

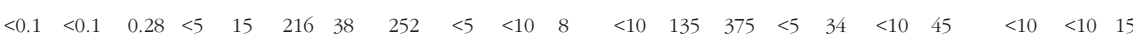
$\begin{array}{lllllllllllllllllllll}<0.1 & <0.1 & 0.15 & <5 & 11 & 79 & 13 & 94 & 12 & <10 & <5 & <10 & 306 & 383 & <5 & 31 & <10 & 127 & <10 & <10 & 25\end{array}$ $\begin{array}{lllllllllllllllllllll}<0.1 & <0.1 & <0.1 & <5 & 12 & 189 & 12 & 159 & 96 & <10 & 24 & 13 & 256 & 190 & <5 & 21 & <10 & 1387 & <10 & <10 & 33\end{array}$

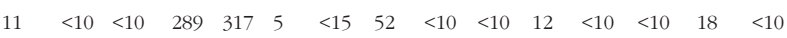
$\begin{array}{lllllllllllllll}<10 & 12 & 30 & 57 & 23 & 70 & <15 & 21 & 70 & 16 & 24 & <10 & <10 & <10 & <10\end{array}$ $\begin{array}{lllllllllllllll}<10 & <10 & 11 & 55 & 18 & 27 & 17 & 14 & 75 & 116 & 64 & 34 & <10 & <10 & 18\end{array}$ $\begin{array}{lllllllllllllll}<10 & <10 & 101 & 271 & <10 & 478 & <15 & 240 & 143 & 35 & <10 & <10 & <10 & 54 & <10\end{array}$ $\begin{array}{lllllllllllllll}<10 & 13 & 31 & 94 & 168 & 99 & <15 & 28 & 28 & 31 & 30 & 12 & <10 & <10 & <10\end{array}$ $\begin{array}{lllllllllllllll}<10 & <10 & 11 & 38 & <10 & <5 & <15 & 6 & 97 & 66 & 44 & 32 & <10 & <10 & 10\end{array}$

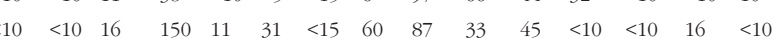
$\begin{array}{llllllllllll}106 & <10 & 98 & <15 & 34 & 72 & 182 & 94 & 22 & <10 & <10 & 30\end{array}$ $\begin{array}{llllllllllll}120 & 51 & 61 & <15 & 59 & 41 & 16 & 32 & <10 & <10 & <10 & 10\end{array}$

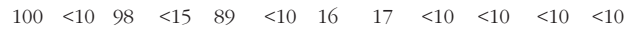

$\begin{array}{lllllllllllllllllllll}<0.1 & <0.1 & <0.1 & <5 & 16 & 444 & 29 & 1019 & 139 & <10 & 17 & 40 & <10 & 22 & <5 & 11 & 14 & 4115 & <10 & <10 & 22\end{array}$ $\begin{array}{lllllllllllllllllllll}<0.1 & <0.1 & 0.11 & <5 & 27 & 677 & 82 & 263 & 119 & <10 & 26 & 36 & 12 & 15 & <5 & 12 & 11 & 2104 & <10 & <10 & 19\end{array}$ $\begin{array}{lllllllllllllllllllll}<0.1 & <0.1 & <0.1 & <5 & 22 & 199 & 10 & 468 & 245 & <10 & 44 & 43 & 21 & 20 & <5 & 11 & <10 & 1660 & <10 & <10 & 22\end{array}$ $\begin{array}{lllllllllllllllllllll}<0.1 & <0.1 & <0.1 & <5 & 28 & 1421 & 48 & 28 & 95 & <10 & 14 & 29 & 15 & 11 & <5 & 12 & 26 & 344 & <10 & <10 & 18\end{array}$ $\begin{array}{lllllllllllllllllllll}<0.1 & <0.1 & 0.11 & 6 & 64 & 589 & 82 & 87 & 226 & <10 & 40 & 39 & 14 & <10 & <5 & 11 & <10 & 1028 & <10 & <10 & 25\end{array}$

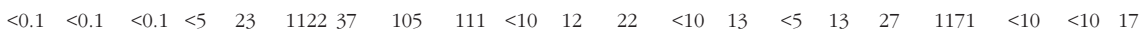
$\begin{array}{lllllllllllllllllllll}<0.1 & <0.1 & <0.1 & <5 & 5 & 104 & 5 & 217 & 71 & <10 & 10 & 14 & 17 & 15 & <5 & 10 & <10 & 1006 & <10 & <10 & 10\end{array}$ $\begin{array}{lllllllllllllllllllll}<0.1 & <0.1 & <0.1 & <5 & 34 & 430 & 297 & 57 & 123 & <10 & 12 & 28 & 11 & <10 & <5 & 10 & <10 & 279 & <10 & <10 & 19\end{array}$ $\begin{array}{lllllllllllllllllllll}<0.1 & <0.1 & 0.18 & 16 & 49 & 399 & 77 & 223 & 209 & <10 & 24 & 34 & 19 & 14 & <5 & 11 & 12 & 1074 & <10 & <10 & 16\end{array}$ $\begin{array}{lllllllllllllllllllll}<0.1 & <0.1 & <0.1 & <5 & 10 & 349 & 23 & 27 & 103 & <10 & 14 & 16 & 21 & <10 & <5 & <10 & <10 & 672 & <10 & <10 & 16\end{array}$ $\begin{array}{lllllllllllllllllllll}<0.1 & <0.1 & <0.1 & 18 & 29 & 633 & 41 & 854 & 108 & <10 & 7 & 23 & <10 & 22 & <5 & 11 & 19 & 3817 & <10 & <10 & 21\end{array}$ $\begin{array}{lllllllllllllllllllll}<0.1 & <0.1 & 0.12 & <5 & 54 & 276 & 92 & 137 & 187 & <10 & 19 & 26 & 13 & 14 & <5 & <10 & <10 & 627 & <10 & <10 & 19\end{array}$ $\begin{array}{lllllllllllllllllllll}<0.1 & <0.1 & 0.16 & <5 & 54 & 911 & 78 & 194 & 150 & <10 & 12 & 29 & 13 & 10 & <5 & 12 & 23 & 2958 & <10 & <10 & 24\end{array}$

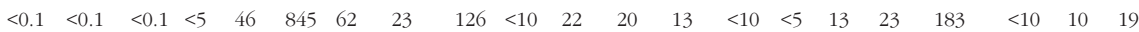
$\begin{array}{lllllllllllllllllllll}<0.1 & <0.1 & 0.32 & <5 & 47 & 857 & 69 & 307 & 199 & <10 & 41 & 15 & 15 & 46 & <5 & <10 & 24 & 1279 & <10 & <10 & 19\end{array}$ $\begin{array}{lllllllllllllllllllll}<.1 & <0.1 & 0.15 & <5 & 64 & 544 & 59 & 463 & 95 & <10 & <5 & 14 & <10 & 13 & <5 & 15 & 20 & 2589 & <10 & <10 & 20\end{array}$ $\begin{array}{lllllllllllllllllllll}<0.1 & <0.1 & 0.12 & 8 & 47 & 456 & 47 & 195 & 126 & <10 & 21 & 14 & 15 & <10 & <5 & <10 & <10 & 942 & <10 & <10 & 19\end{array}$

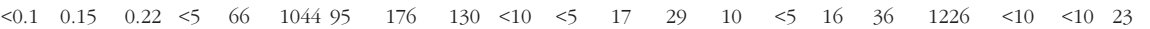

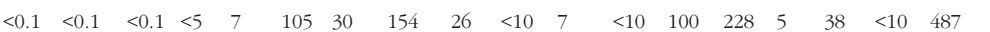

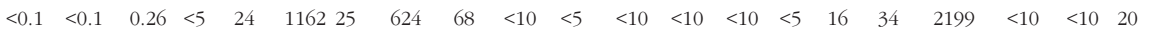

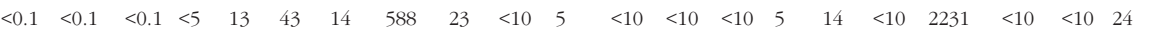
$\begin{array}{lllllllllllllllllllll}<0.1 & 0.19 & 0.15 & <5 & 34 & 516 & 50 & 767 & 93 & <10 & 16 & 19 & 42 & 169 & <5 & 19 & 60 & 1203 & <10 & <10 & 23\end{array}$ $\begin{array}{lllllllllllllllllllll}<0.1 & 0.20 & 0.21 & <5 & 26 & 571 & 43 & 761 & 84 & <10 & 11 & 17 & 27 & 146 & <5 & 25 & 76 & 1284 & <10 & <10 & 19\end{array}$

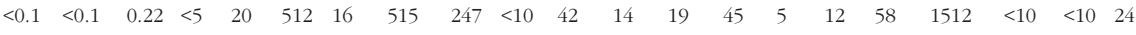

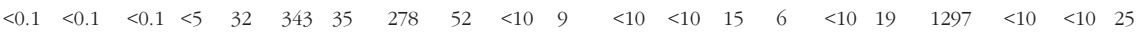
$\begin{array}{lllllllllllllllllllll}<.1 & 0.17 & <0.1 & <5 & 29 & 640 & 57 & 125 & 157 & <10 & 16 & 24 & <10 & <10 & <5 & <10 & 66 & 830 & <10 & <10 & 22\end{array}$ $\begin{array}{lllllllllllllllllllll}<0.1 & <0.1 & <0.1 & <5 & 9 & 210 & 17 & 502 & 32 & <10 & 9 & <10 & 32 & 70 & <5 & 17 & <10 & 998 & <10 & <10 & 11\end{array}$ $\begin{array}{lllllllllllllllllllll}<0.1 & 0.16 & 0.18 & <5 & 34 & 940 & 64 & 291 & 166 & <10 & 21 & 34 & 16 & 19 & <5 & 11 & 121 & 1643 & <10 & <10 & 16\end{array}$ $\begin{array}{lllllllllllllllllllll}<0.1 & <0.1 & 0.18 & <5 & 75 & 33 & 21 & 2737 & 158 & <10 & <5 & <10 & 11 & 21 & <5 & <10 & 29 & 2521 & <10 & <10 & 14\end{array}$

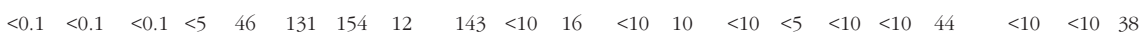
$\begin{array}{lllllllllllllllllllll}<0.1 & <0.1 & 0.43 & <5 & 42 & 366 & 52 & 418 & 61 & <10 & 12 & <10 & 15 & 151 & <5 & 19 & 10 & 960 & <10 & <10 & 16\end{array}$

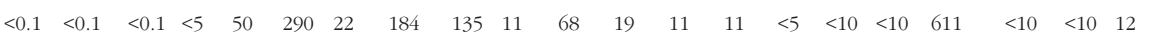
$\begin{array}{lllllllllllllllllllll}<.1 & <0.1 & <0.1 & <5 & 305 & 2903 & 100 & 48 & 255 & 14 & 71 & 45 & <10 & 16 & <5 & <10 & 90 & 88 & <10 & 15 & 42\end{array}$

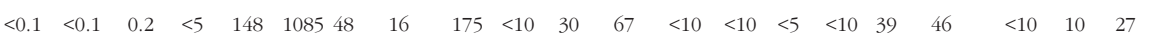

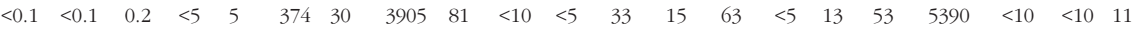

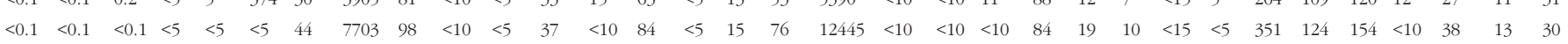
$\begin{array}{lllllllllllllllllllllllllllllllllllllll}<0.1 & <0.1 & 0.2 & <5 & 18 & 208 & 23 & 376 & 133 & <10 & 21 & 19 & <10 & 19 & <5 & <10 & <10 & 1538 & <10 & <10 & 15 & 50 & <10 & <5 & <15 & <5 & 127 & 96 & 36 & 34 & <10 & <10 & 12\end{array}$

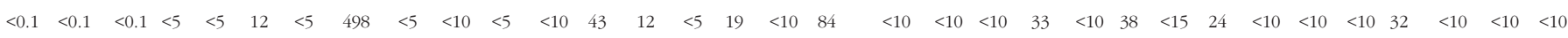

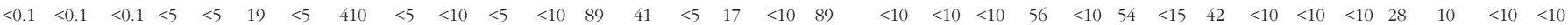
$\begin{array}{llllllllllllllllllllllllllllllllllllllllll}<0.1 & <0.1 & <0.1 & <5 & 8 & 180 & 26 & 198 & 103 & <10 & 10 & <10 & 28 & 20 & <5 & <10 & <10 & 1165 & <10 & <10 & 12 & 46 & <10 & <5 & <15 & 5 & 78 & 44 & 30 & 30 & <10 & <10 & 11\end{array}$ $\begin{array}{llllllllllllllllllllllllllllllllllllllllll}<.1 & <0.1 & 0.11 & <5 & 14 & 250 & 38 & 195 & 120 & <10 & 11 & 18 & 12 & 30 & <5 & <10 & <10 & 1295 & <10 & <10 & 10 & 71 & <10 & <5 & <15 & 10 & 54 & <10 & 14 & 25 & <10 & <10 & <10\end{array}$ $\begin{array}{llllllllllllllllllllllllllllllllllllllllll}<.1 & <0.1 & 0.1 & <5 & 16 & 231 & 45 & 418 & 113 & <10 & 21 & 18 & 13 & 19 & <5 & <10 & <10 & 1497 & <10 & <10 & 12 & 55 & <10 & <5 & <15 & <5 & 293 & 210 & 98 & 33 & 15 & <10 & 34\end{array}$

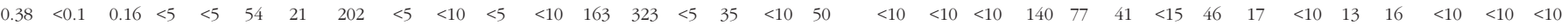
$\begin{array}{lllllllllllllllllllllllllllllllllllllllllllll}<.1 & <0.1 & 0.28 & <5 & 12 & 201 & 33 & 234 & 123 & <10 & 13 & 18 & <10 & 26 & <5 & 12 & <10 & 1163 & <10 & <10 & 12 & 61 & <10 & 5 & <15 & 7 & 57 & 16 & 21 & 27 & <10 & <10 & <10\end{array}$ \begin{tabular}{lllllllllllllllllllllllllllllllll}
$<0.1$ & $<0.1$ & $<0.1$ & $<5$ & 12 & 148 & 41 & 127 & 142 & $<10$ & 15 & 19 & 20 & 14 & $<5$ & $<10$ & $<10$ & 860 & $<10$ & $<10$ & 13 & 48 & $<10$ & 5 & $<15$ & $<5$ & 47 & 32 & 24 & 41 & $<10$ & $<10$ & $<10$ \\
\hline
\end{tabular} 